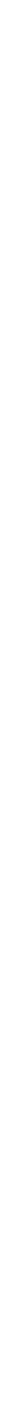

Geraldine E. Schwab

W.K. Summers

Robert M. Colpitts, Jr.
Claire E. Teuten

Wesley K. Young

T.

1

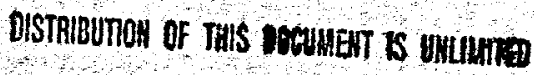

Prepared for the

U.S Department of Energy

Idaho Operations Office

Under DOE Contract No. DE-AC07-76ID01570

$\prod_{S} E E_{2} G_{\text {dano }}$ 


\section{DISCLAIMER}

This report was prepared as an account of work sponsored by an agency of the United States Government. Neither the United States Government nor any agency Thereof, nor any of their employees, makes any warranty, express or implied, or assumes any legal liability or responsibility for the accuracy, completeness, or usefulness of any information, apparatus, product, or process disclosed, or represents that its use would not infringe privately owned rights. Reference herein to any specific commercial product, process, or service by trade name, trademark, manufacturer, or otherwise does not necessarily constitute or imply its endorsement, recommendation, or favoring by the United States Government or any agency thereof. The views and opinions of authors expressed herein do not necessarily state or reflect those of the United States Government or any agency thereof. 


\section{DISCLAIMER}

Portions of this document may be illegible in electronic image products. Images are produced from the best available original document. 


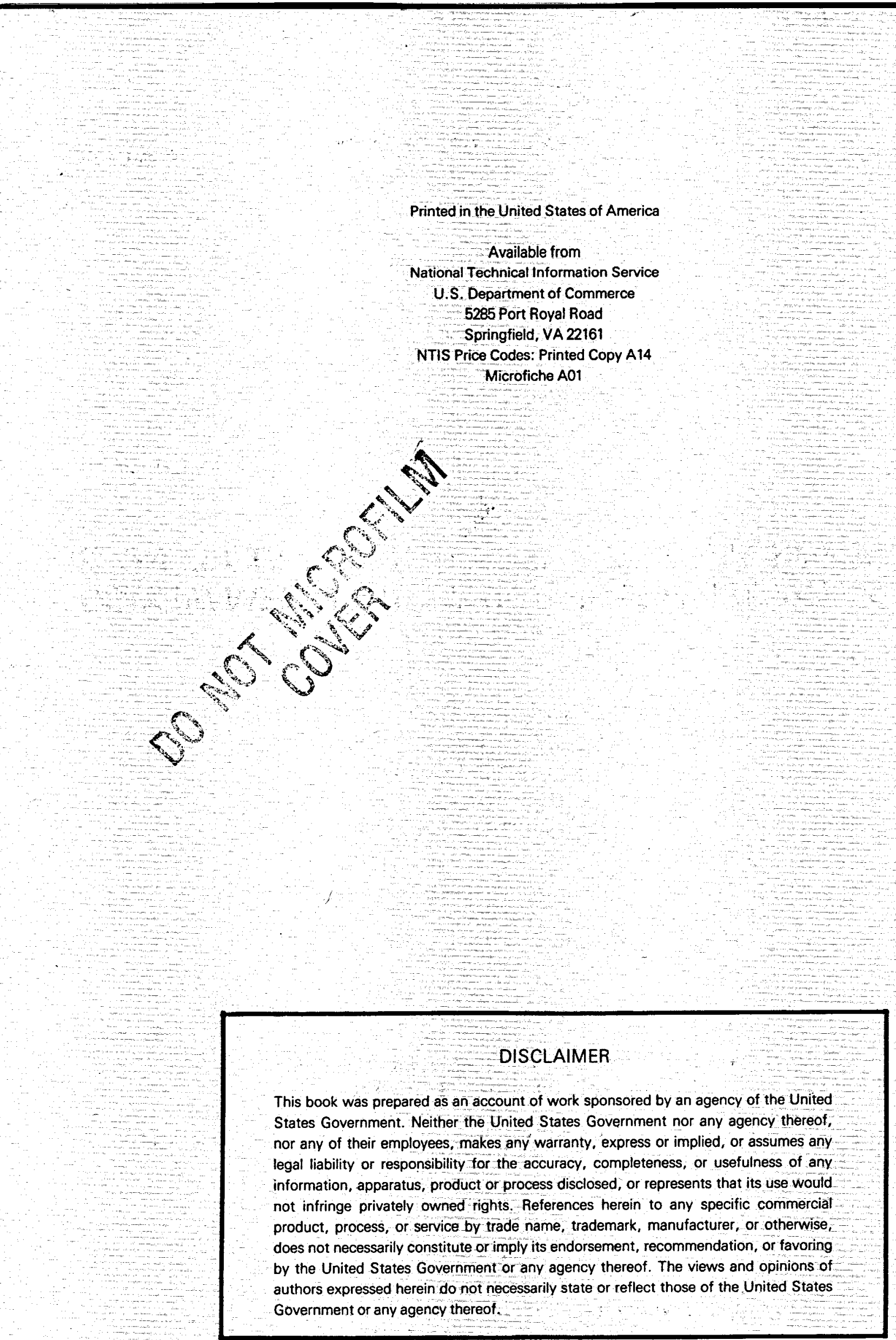


EGG--2156

DE82 012029

DISCLAIMER

This book was preaared as an account of work sponsored by an agency of the United States Government. Neither the United States Government nor any sqency thereof, nor ary cf their empioyses, makes any warranty, express of implied, of assumes any legal liability of responsibility for the sccuracy, completeness, of usefulness of any intormation, apparatus, product, or process disclosed.

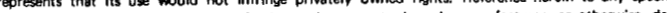

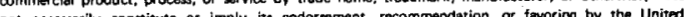

\title{
PUMPING TESTS OF WELL CAMPBELL ET AL. NO. 2 GILA HOT SPRINGS, GRANT COUNTY, NEW MEXICO
}

\author{
Geraldine E. Schwab \\ W.K. Summers \\ Robert M. Colpitts, Jr. \\ Claire E. Teuten \\ Wesley K. Young
}

Published March 1982

W.K. Summers and Associates, Inc. Socorro, New Mexico 87801

Prepared for EG\&G Idaho, Inc.

Under Subcontract No. K-7836, Modification No. 1

and the U.S. Department of Energy

Idaho Operations Office

Under DOE Contract No. DE-AC07-76ID01570

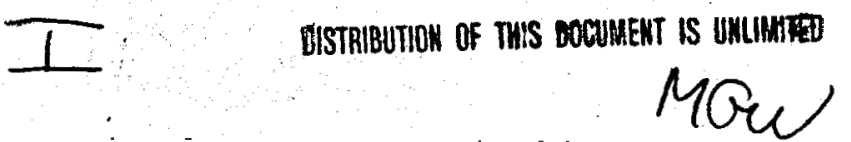




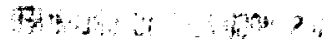

II 


\section{PREFACE}

W.K. Summers and Associates, Inc., prepared this report for EG\&G Idaho on Subcontract No. K-7836, Modification No. 1 under the Department of Energy's Outreach Program. It is being reissued as an EG\&G formal report to make it available to others who may be interested in this goethermal application.

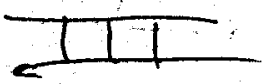





\section{FOREWORD}

The Geothermal Technical Assistance Program was developed under the premise that the majority of groups or individuals with available geothermal resources do not have the experience or manpower necessary to do a preliminary engineering and economic feasibility evaluation for geothermal energy projects. In order to disseminate technical information and to facilitate expanded use of geothermal energy resources, assistance was provided through FY-1981 in a consulting format on a first-come, staff-andfunds-available basis. Technical assistance can relate to conceptualization; engineering; economics; water chemistry implications for environmental, disposal, and material selection considerations; and planning and development strategies. This report is one of a series adapted from consultation provided to requesters either through in-house efforts or through limited efforts subcontracted to local engineering firms. The Geothermal Technical Assistance (GTA) Reports in this series, which are listed below, will be available for purchase early in 1982 by those with interest in specific geothermal applications from the U.S. National Technical Information Service:

U.S. Department of Commerce,

National Technical Information Service, 5285 Port Royal Road, Springfield, VA 22161, (703) $557-4650$

GTA Report Number.

1.

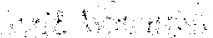

2.

3.

4.

5.

6.

7. EGG-GTH-5617

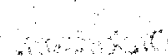

*EGG-GTH-5573

EGG-GTH-5575

*EGG-GTH-5599

\section{Preliminar} Health Laboratory, Boise, Idaho

Aquaculture Facility Potential at Boulder Hot Springs, Boulder, Montana

Hexpand

Geothermal Conversion Idaho

at Veterans Hospital, Boise,

ans

Geothermal Applications for Highway Rest Areas

Geothermal Applications for a Tannery

Preliminary Conceptual Design for Geothermal Space Heating Conversion of School District 50 Joint Facilities at Pagosa Springs, Colorado

Selected Geothermal Technical Assistance Efforts (comprising short descriptions of ten space heating projects, five district heating projects, and three heat exchanger projects)

8.

•EGG-2137

Geothermal Source Potential and Utilization for Methane Generation and Alcohol Production (subcontractor report)

9.

*EGG-2138

Geothermal Source Potential and Utilization for Alcohol Production (subcontractor report) 
GTA

10.

11.

12.

13.

14.

15.

16.

17.

18.

19.

20.

21.

22.

23.

24.

25.
*EGG-2145

EG\&G

Report Number

•EGG-2139

-EGG-2144

EGG-2146

EGG-2147

-EGG-2148

EGG-2149

EGG-2150

EGG-2151

EGG-2152

EGG-2153

EGG-2154

EGG-2155

EGG-2156

*EGG-GTH-5739

*EGG-GTH-5740
Title

Potential Geothermal Energy Applications for Idaho Elks Rehabilitation Hospital (subcontractor report)

Technical Assistance Report on a Geothermal Heating Utility for Lemmon, South Dakota (subcontractor report)

Economic Analysis for Utilization of Geothermal Energy by North Dakota Concrete Products Company (subcontractor report)

Geothermal Feasibility Analysis II for Polo School District No. 29-2, South Dakota (subcontractor report)

Preliminary Feasibility Study of Heating and Cooling Alternatives for Nebraska Western College, Scottsbluff, Nebraska (subcontractor report)

Inventory of Thermal Springs and Wells Within a OneMile Radius of Yucca Lodge, Truth or Consequences, New Mexico (subcontractor report)

Space Heating for Spa Facilities at Ojo Caliente, New Mexico (subcontractor report)

Space Heating for Office Building at Glenwood Springs, Colorado (subcontractor report)

District Heating for Subdivision in Dickinson, North Dakota (subcontractor report)

Space Heating for Subdivision in Truth or Consequences, New Mexico (subcontractor report)

Space Heating for Veterans Administration Medical Center, Marlin, Texas (subcontractor report)

District Heating for Subdivision in Castle Rock, Colorado (subcontractor report)

Space Heating for Twin Lakes School Near Gallup, New Mexico (subcontractor report)

Pumping Tests of Well Campbell Et Al. No. 2, Gila Hot Springs, Grant County, New Mexico (subcontractor report)

Geothermal Deicing of Bridge Structures

Assessment of a Geothermal Application at Tucson, Arizona 
GT

Report Number

26.

27.

28.

29.
EGG-GTH-5804

EG\&G

Report Number

•EGG-GTH-5741

EGG-GTH-5779

EGG-GTH-5812
Title

Heat Pump Systems for Spring Creek, Montana

Pipe Selection Guide

An Overview of Engineering and Agricultural Design Considerations of the Raft River Soil-Warming and Heat-Dissipation Experiment

Design of the Glenwood Springs Downhole Heat Exchanger

- Published as of 3/15/82. 


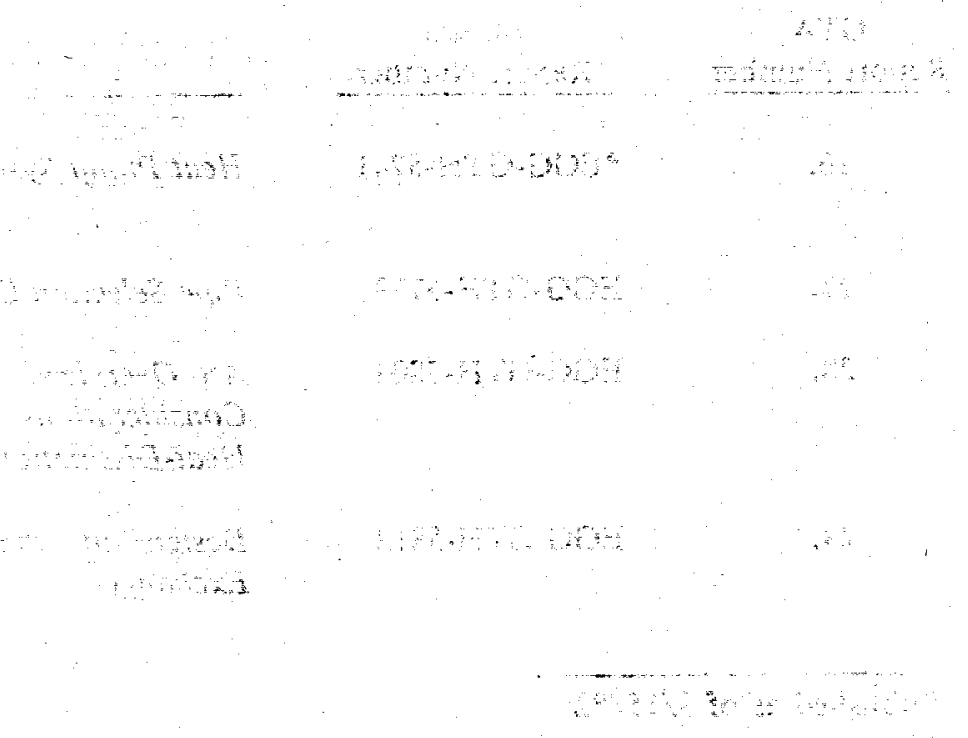

$\checkmark$

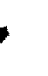


PUMPING TESTS OF

WELL CAMPBELL ET AL. NO. 2

U OTILA HOT SPRINGS,

GRANT COUNTY, NEW MEXICO

Geraldine E. Schwab

W.K.:Summers

Robert M. Colpitts, Jr.

at.

Wesley $\mathrm{K}$. Young

Submitted January 1982

W.K. Summers and Associates, Inc.

Socorro, New Mexico 87801

Prepared for EG\&G Idaho, Inc.

Under Subcontract No. $\mathrm{K}-7836$, Modification No. 1 


\section{ABSTRACT}

Well Campbell et al. No. 2 near Gila Hot Springs in southwestern New Mexico (Section 5, Township 13 South, Range 13 West) was pumped for a five-step test and a 48-hour constant-rate test during October 1981. Measurements included depth to water in the pumping well and two observation wells, and discharge rates at the pumping well and two springs.

The water level in the pumping well responded during both tests. However, water-level changes in the observation wells were too small for analytical use and discharge rates from the springs showed no change.

Chemical analyses of water samples collected from two springs and the pumping well show very similar water chemistries.

Estimates of hydraulic properties show transmissivity from 12,000 to $14,000 \mathrm{gpd} / \mathrm{ft}$ and a storativity of 0.05 . Combining these parameters with well data gives the first-year optimum discharge rate as $50 \mathrm{gpm}$ with 20 feet of drawdown.

Pumping this well at $50 \mathrm{gpm}$ for forty years should produce only small water-level changes in wells a few hundred feet away. It would diminish the flow of the springs, and for planning purposes the combined discharge of the springs and well should be considered constant. 


\section{ACKNOWLEDGMENTS}

We wish to express our appreciation to the entire Campbell family for their help during these tests. Collectively, the Campbel1s provided extra workers, assorted test equipment and support equipment, delicious food, and comfortable lodging, all of which made this project much easier for us to carry out. We especially thank Doc, Ida, Allen, and Angus Campbell for their constant assistance.

Lynn Brandvold of the New Mexico Bureau of Mines and Mineral Resources graciously consented to provide complete chemical analyses of water samples collected during this test program.

We also gratefully acknowledge the help of Dennis Fedor of the New Mexico Energy and Minerals Department, and Ivar Engen and M.C. Stone of EG\&G Idaho, Inc. with the administrative details that made the project posisible. 


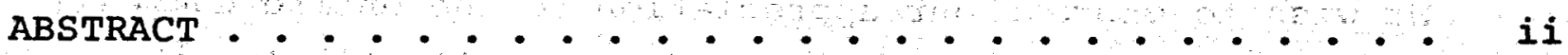

ACKNOWLEDGMENTS • . + . . . . . . . . . . .

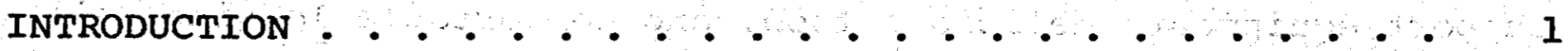

Background. - . . . . . . . . . . . . 1

Purpose and scope . . . . . . . . . . . . . 3

Topography and Drainage . . . . . . . . . . . 4

Geology - . . . . . . . . . . . . . . 4

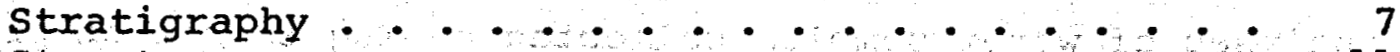

structure. . . . . . . . . . . . . . . 11

Water-Bearing Properties of Rocks . . . . . . . 11

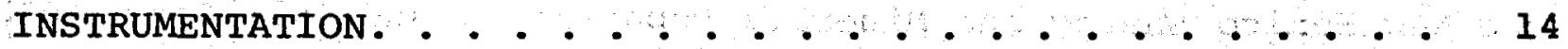

Discharge Measurements. . . . . . . . . . 14

Flow Meter .. ... . . . . . . . 14

Flumes...................... 14

Depth-to-Water Measurements . . . . . . . . . 15

Steel Tapes. . . . . . . . . . . . 15

Water-Level Monitors . . . . . . . . . 19

Cross-Checks . . . . . . . . . . . . . 20

Water Temperature and Chemistry . . . . . . . . . 21

Temperature. ................... 21

Specific Conductance............. 23

Silica.................... 23

Carbonate and Bicarbonate. . . . . . . . . 23

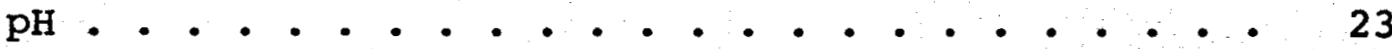

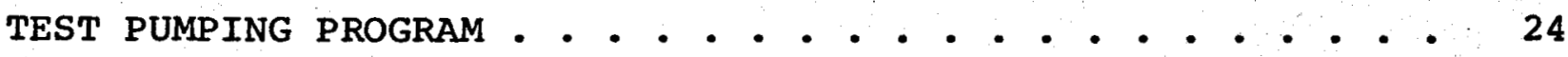

Program Summary . . . . . . . . . . . . . . 24

Pre-test Measurements. . . . . . . . . 24

Step Test. . . . . . . . . . . . . . . 27

Constant-Rate Test . . . . . . . . . 28

Water Samples. . . . . . . . . . 30 
Test Results. . . . . . . . . . . , 32

Data Interpretation. . . . . . . . 32

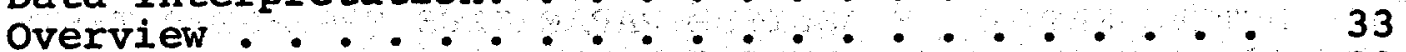

Step Test. . . . . . . . . ..... 33

Constant-Rate Test . . . . . . . . . 33

Temperature. . . . . . . . . . 38

DISCUSSION . . . . . . . . . . . . . . . . 42

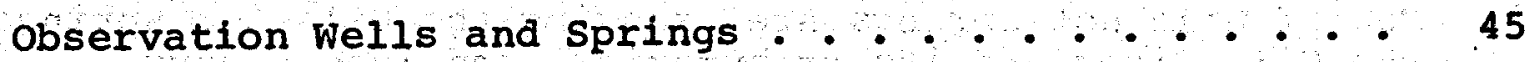

Specific yield . . . . . . . . . . . 47

water not from storage........ .48

Anisotropism . . . . . . . . . . . . 49

Partial Penetration. . . . . . . . . 49

Postscript . . . . . . . . . . ... 50

Optimum Instantaneous Discharge and "First-Year" Yield. 50

Head Changes. . . . . . . . . . . 51

In Pumping Well. . . . . ........ 51

Around Pumping Well. . . . . . . . . 54

Impact on the springs . . . . . . ...... 55

Maximum Temperature . . . . . . . . . 55

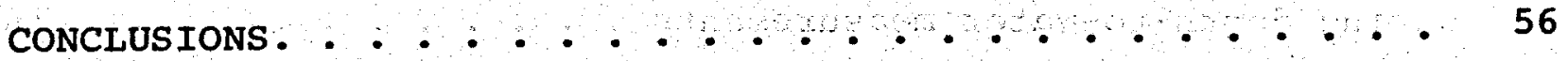

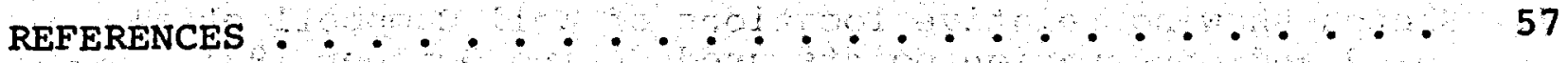

\section{APPENDICES}

A. WELL CAMPBELL ET AL. NO. $2 \ldots \ldots 59$

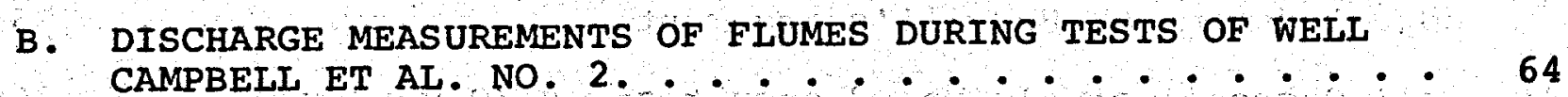

C. STEP TEST DATA FROM WELL CAMPBELL ET AL. NO, 2 AND

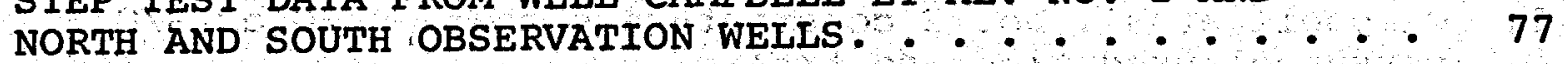

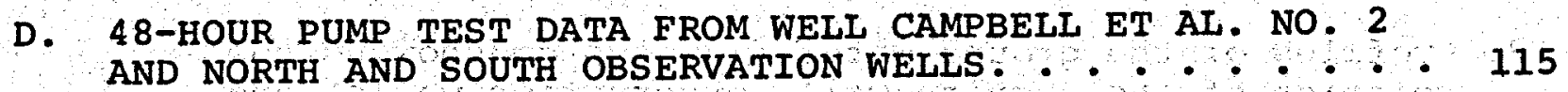

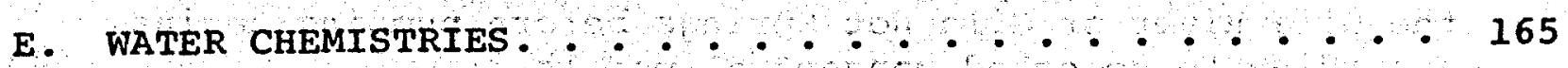

F. VERTICALLY-AVERAGED HEAD . . . . . . . . . . 173 
G. ESTIMATING THE OPTIMUM AND "FIRST-YEAR" YIELDS OF A

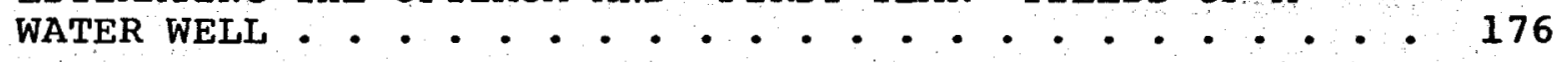

H. DETERMINATION OF AQUIFER PARAMETERS FROM STEP TESTS AND INTERMITTENT PUMPING DATA....$\cdot \ldots$ heprint renovide

\section{FIGURES}

1. Map of Gila Hot Springs Area showing the Gila Hot springs, the Gila River and its tributaries, and land status. .

2. Geologic map of the Gila Hot Springs area, Grant and Catron Counties, New Mexico...... . . . . . . . 5

2A. Explanation to Figures 2, 3, and 4, . . . . . . . 6

3. Geologic cross-section $A A^{\prime}$ showing isotherms near the Gila Hot springs . . . . . . . . . . . . . . . .

4. Geologic cross-section $\mathrm{BB}^{\prime}$ showing isotherms near the Gila Hot Springs . . . . . . . . . . . . . . . .

5. Map showing the spatial relations among grabens, caldera, geophysical anomalies, and hot springs in the region around the Gila Hot Springs. . . . . . . . . . . . .

6. Diagrammatic illustration of some problems encountered during depth-to-water measurements . . . . . . . . . 18

7. Sketch showing relative locations of Well Campbell et al. No. 2 and observation points used during October 1981 pumping tests..... . . . . . . . . . . . . . . 26

8. Drawdown, discharge, and temperature of discharging water at Well Campbell et al. No. 2, October 12, 1981. . . . .

9. Well Campbell et al. No. 2 step test, s'/Q or $s / Q$ versus adjusted time or Harrili's argument. . . . . . . . 35

10. Well Campbell et al. No. 2 step test, s'/Q versus $Q . . \quad 36$

11. Campbell et al. No. 2 constant-rate test, $s^{\prime} / Q$ or $s / Q$

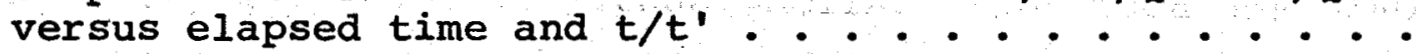

12. Profiles of the ground water flow system showing the relation of the pumping well, observation wells, and the Gila River or Gila Hot springs before pumping begins according to selected conceptual models. . . . . . . . 
13. Profiles of the ground water flow system showing the relation of the pumping well, observation well, and the Gila River or Gila Hot Springs during the pumping period according to selected conceptual models .

F-1.Head distribution, head at the water table, and vertically-averaged head in one cross-section. . . . . . .

TABLES

1. FIELD MEASUREMENTS FOR WATER SAMPLES COLLECTED DURING PUMPING TESTS OF WELL CAMPBELL ET AL. NO. $2 . . \ldots$

2. TEMPERATURE OF WATER DISCHARGING FROM WELL CAMPBELL ET AI. NO, 2 DURING PUMPING TESTS, OCTOBER $1981 \ldots$

3. DRAWDOWN DUE TO WELIL INEFFICIENCY AND TOTAL DRAWDOWN IN WELL CAMPBELL ET AL, NO. 2 AT END OF ONE YEAR, BASED ON $T=13,900 \mathrm{gpd} / \mathrm{ft} . \ldots \ldots \ldots$

4. DRAWDOWN DUE TO WELL INEFFICIENCY AND TOTAL DRAWDOWN EXPECTED IN WELL CAMPBELL ET AL. NO. 2 BASED ON

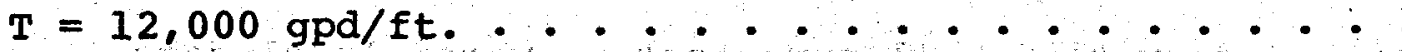

B-1.Discharge measurements at flume no. 1 , Gila Hot springs New Mexico, in October 1981. . . . . , . . . .

B-2.Discharge measurements at flume no. 1-A, Gila Hot

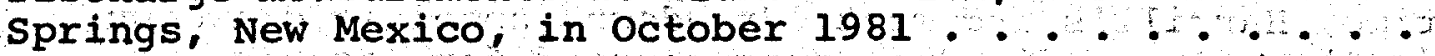

B-3.Discharge measurements at flume no..2, Gila Hot springs, New Mexico, in October 1981. . . . . . . . 71

C-1.Well Campbell et al. No. 2 - average discharge by steps 78

C-2.Well Campbell et al. No. 2 step test - metered discharge

C-3.Wel1 Campbe11 et a1. No. 2 step test-- water level data

C-4.Well Campbell et al. No. 2 step test -- depth-to-water.

c-5. Well Campbell et al. No. 2 step test - calculated adjusted time, Harrill's argument, drawdown, specific drawdown $(s / Q)$ and specific drawdown adjusted for Jacob's. correction $\left(s^{\prime} / Q\right)$.

c-6. North observation Well step test - water level data.

c-7.North observation Well step test - depth-to-water . . 
C-8. North Observation Well step test - calculated adjusted time, Harrill's argument, drawdown, specific drawdown $(s / Q)$ and specific drawdown adjusted for Jacob's correction $(s: / Q)$.

C-9.South Observation well step test - - water level data $\cdot \cdot 103$

C-10.South observation well step test - depth-to-water. . 107

C-11.South Observation Well step test -- calculated adjusted time, Harrill's argument, drawdown, specific drawdown $(s / Q)$ and specific drawdown adjusted for Jacob's correction $(s / / Q) \cdot \ldots \ldots \ldots \ldots \ldots \ldots \ldots \ldots \ldots, 111$

D-1.Campbell et al. No. 2 pump test -- metered discharge . . 116

D-2.Campbell et al. No. 2 pump test - water level data. - 123

D-3.Campbell et al. No. 2 pump test -- depth-to-water.. .131

D-4.Campbell et al. No. 2 pump test - - calculated adjusted time, Harrill's argument, drawdown, specific drawdown $(s / Q)$ and specific drawdown adjusted for Jacob's

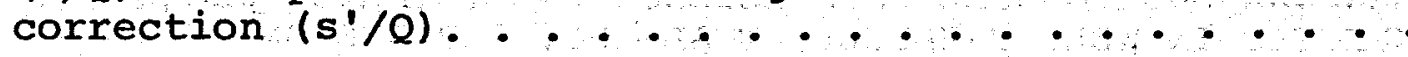

D-5.North Observation Well pump test - - water level data . 147

D-6.North Observation Well pump test -- depth-to-water . . 150

D-7. North Observation Well pump test -- calculated adjusted time, Harrill's argument, drawdown, specific drawdown $(s / Q)$ and specific drawdown adjusted for Jacob's correction $\left(\mathrm{s}^{\prime} / \mathrm{Q}\right)$. . . . . . . . 153

D-8.South Observation Well pump test -- water level data . 156

D-9.South observation well pump test -- depth-to-water . . 159

D-10.South Observation Well pump test - calculated adjusted time, Harrill!s argument, drawdown, specific drawdown $(s / Q)$ and specific drawdown adjusted for Jacob!s correction $\left(s^{\prime} / Q\right)$

E-1.Water chemistry: Gila Hot Springs \#14.

E-2.Water chemistry:

Gila Hot springs \#41

E-3. Water chemistry:

Well Campbell et al. No. $2(1445)$. . 168

E-4.Water chemistry:

Well Campbell et al. No. 2 (1610).

169

E-5.water chemistry:

Well Campbell et al. No. 2 (2252) . . 170

E-6.Water chemistry:

Well Campbell et al. No. 2 (0711) . . 171

E-7.Water chemistry:

Well Campbell et al. No. 2 (1400) ... 
PUMPING TESTS OF WELL CAMPBELL ET AL. NO. 2, GILA HOT SPRINGS, GRANT COUNTY, NEW MEXICO

INTRODUCTION

Background

Well Campbell et al. No. 2 is on the hillside above and east of the spring area at Gila Hot springs in southwestern New Mexico, in Section 5, Township 13 South, Range 13 West. Appendix A presents a brief history of Well campbell et al. No. 2, along with a field $\log , 1$ thologic description, and temperature log of the well. The well was drilled to a total depth of 277 feet on January 20, 1980. Severe caving occurred during drilling from 247 to 277 feet. When the temperature $\log$ was run on January 30 , 1980, the probe could not be lowered deeper than 265 feet. When D.A. Campbell measured the depth before installing the pump for these tests (October 1981), the total depth was only 250 feet.

The Gila Hot springs rise along the east bank of the west Fork of the Gila River and discharge about 200 gallons per minute (gpm) into the river from private land that straddles the west Fork of the Gila River. Most land nearby is either federal

(National Forest, National Monument, Primitive Area, and Wilderness) or state (New Mexico Fish and Game Department) property (Figure 1 ).

The Gila Hot springs discharge water with a maximum temperature of $152^{\circ} \mathrm{F}\left(67^{\circ} \mathrm{C}\right)$. Much of the water discharges from fractures in the rock ten to twenty feet above the Gila River, but some of the water discharges directly into the river.

The Gila Hot springs are the warmest of several warm and hot springs in the upper part of the Gila River Basin. These thermal springs occur in a volcanic terrain of Tertiary age where some faults may still be active. This setting makes the area an 


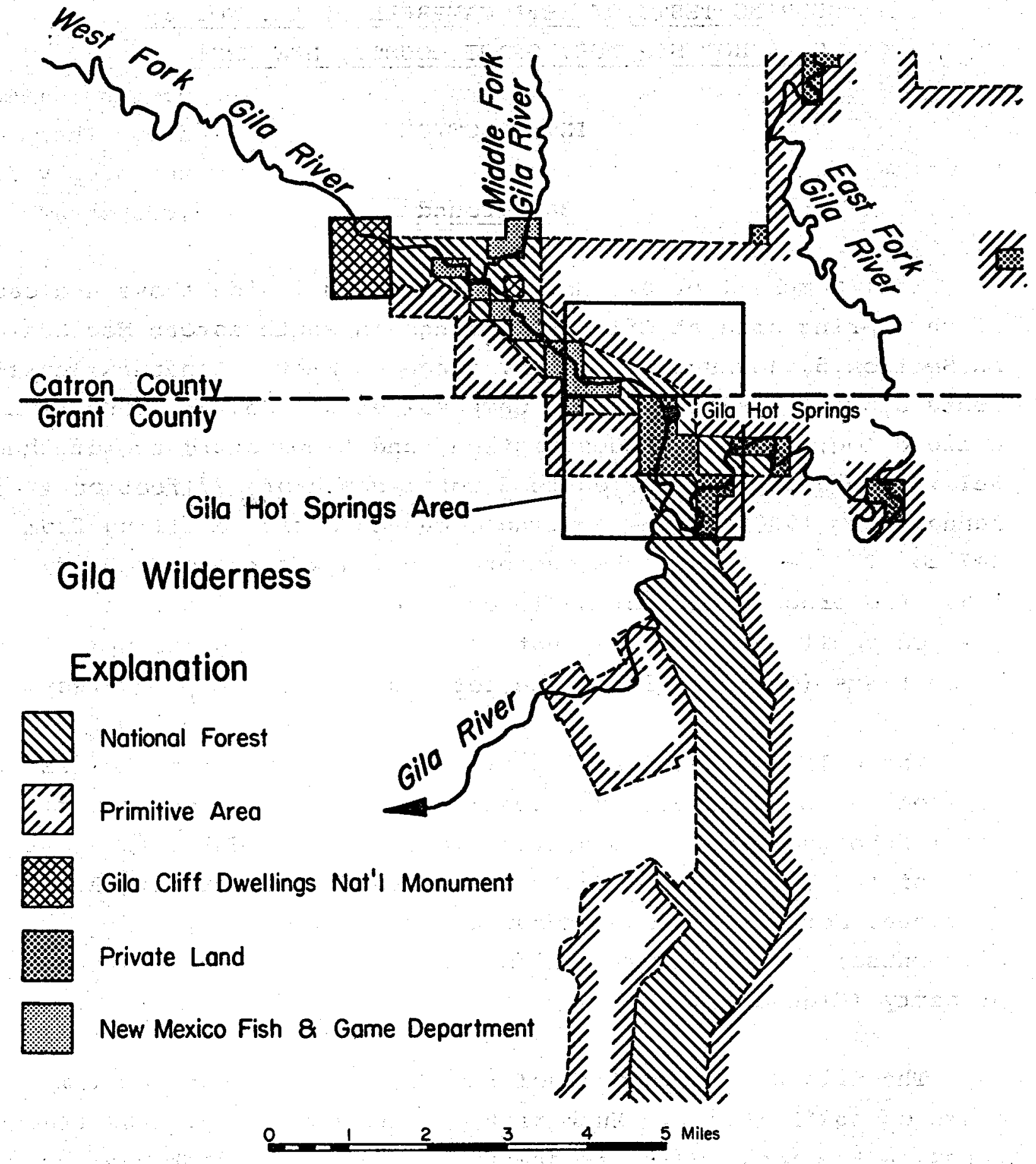

\footnotetext{
Figure 1. Map of Gila Hot Springs Area showing the Gila Hot Springs, the Gila River and its tributaries, and land status.
} 
attractive geothermal prospect.

D.A. "Doc" and Ida Campbell have built collectors and divert the water from the hot springs through pipelines and use the water, both for space heating and as the primary water supply for their operations. They presently heat more than 19,000 square feet of homes and commercial buildings.

Well Campbell et al. No. 2 is currently about 250 feet deep and might provide more and warmer water than is obtained from the springs. Water from the well would be used in place of water from the springs, thereby not only simplifying and improving the collection and distribution system, but increasing the amount of space that could be heated.

\section{Purpose and Scope}

This report presents datalobtained by test pumping Well Campbell et al. No. 2 at Gila Hot Springs in October 1981.

The pumping program was designed to:

1. Learn the hydraulic properties of the rocks in the vicinity of Gila Hot Springs;

2. Estimate the optimum yield of the well;

3. Evaluate the effect of the sustained pumping of the well at the optimum rate on (a) the flow of the springs and (b) the water levels in a neighbor's

Q6. well; and

4. Learn what changes, if any, in the chemistry and temperature of the water discharging from the well and the springs may come about when the well is pumped. 
This report includes a lot of information about the area from previous reports prepared for D.A. and Ida Campbe11.

\section{Topography and Drainage}

Altitudes in the Gila Hot springs area-the area shown in Figure 2- range from 5520 feet in the river valley where it leaves the area to 6832 feet on the ridge above the river. The altitude at Well Campbell et al. No. 2 is 5704 feet. The Gila Hot springs issue through an altitude range from a maximum of about 5600 feet on the hillside down to about 5555 feet in the river bed along the east bank of the West Fork of the Gila River. The West Fork drains part of the western part of the upper Gila River drainage basin. As shown in Figure 1 , the Middle Fork of the Gila River joins the West Fork some three miles above Gila Hot springs, whence the West Fork runs southeast to Gila Hot Springs, then turns south to the confluence with the East Fork, about a mile and a half below Gila Hot springs, Foom the junction of the West and East Forks, the Gila River flows southwest toward Arizona.

The upper Gila River drainage basin shows dendritic and linear drainage patterns.

The West, Middle, and East Forks, and the Gila River below the confluence all flow perennially.

\section{Geology}

The summary of stratigraphy and structure that follows is our interpretation of the works of many geoscientists. It depends largely on the work of Ratte and his associates (Ratte and

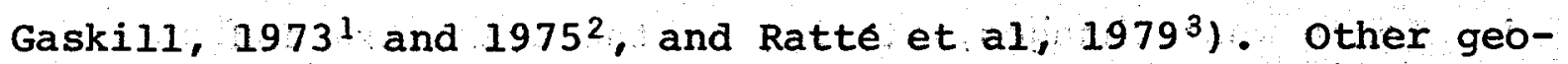
scientists who have contributed to our knowledge of the area are cited in conventional fashion. The work of Ratte and his associates is not cited again. 


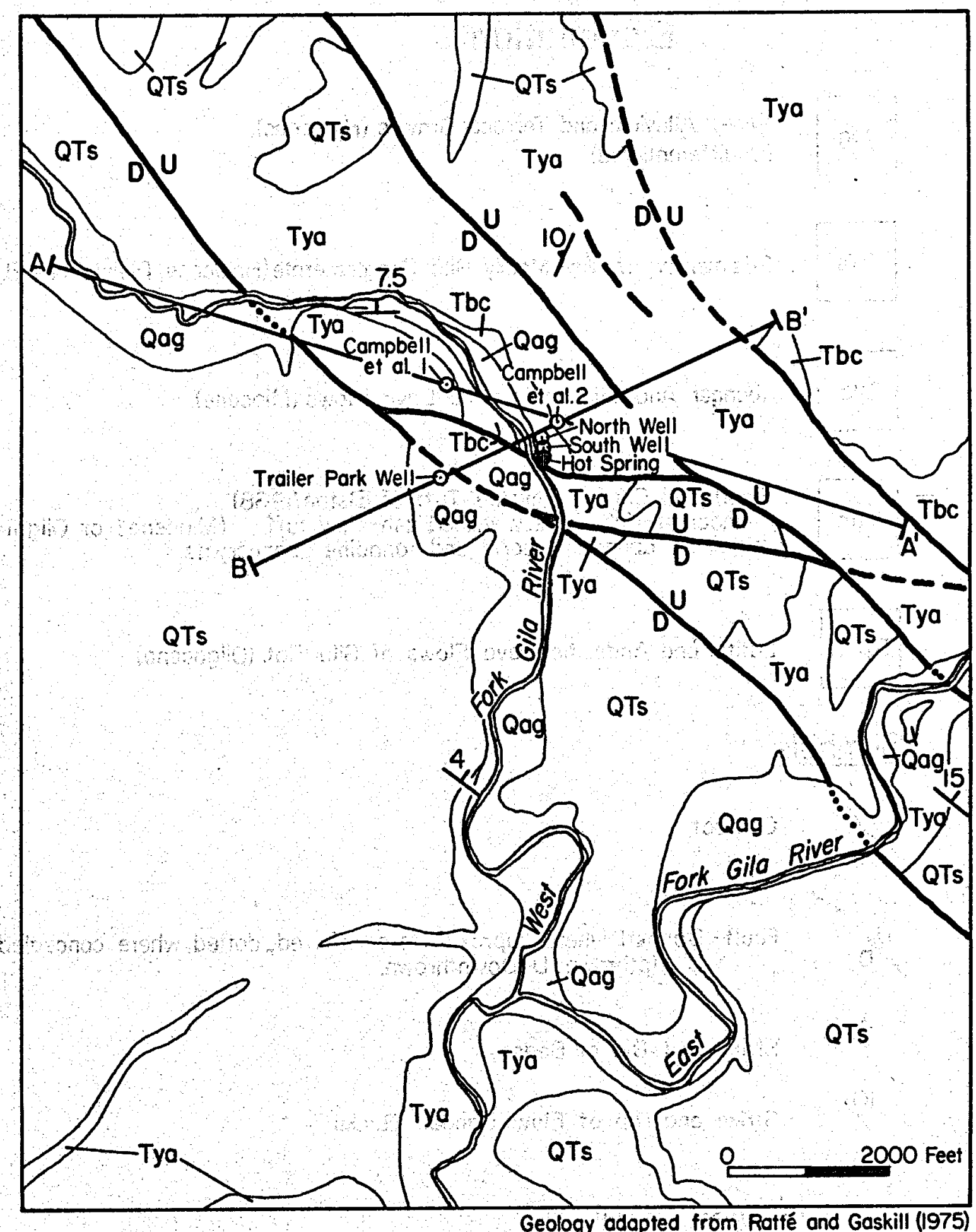

Figure 2. Geologic map of the Gila Hot springs area, Grant and Catron Counties, New Mexico. 


\section{Explanation}

Qag Valley Alluvium and Terrace Gravels (Holocene)
(Undifferentiated)

QTs

Sedimentary Rocks - Mainly Gila Conglomerate (Holocene, Pleistocene \& Pliocene)

Tya Younger Andesitic and Latitic Lova Flows (Miocene) Bloodgood Conyon Rhyolite Tuff of Elston (1968)
Phenocryst-rich densely welded ash-flow tuff (Miocene? or Oligocene?)
containing abundant quartz and sanadine phenocrysts.

Tgf(?) Latitic and Andesitic Lava Flows of Gila Flat. (Oligocene)

\section{Symbols}

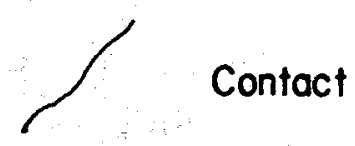

Fault-Dashed where opproximate or inferred, dotted where concealed.
$U=$ Upthrown, $D=D$ ownthrown.

$4 \quad$ Strike and Dip of Beds

10 Strike and Dip of Flow Banded Rocks

$A \longmapsto A^{\prime}$ Cross - Section Line

Figure 2A. Explanation to Figures 2, 3, and 4. 


\section{Stratigraphy}

Figure 2 shows the distribution of the volcanic and sedimentary rocks that crop out around the Gila Hot springs. Figures 3 and 4 are cross-sections through the Gila Hot springs area. Fission track and potassium-argon dates show that the rocks exposed in the Gila Hot Springs area range in age from mid-Tertiary to Holocene.

The volcanic sequence in the area is probably about 3000 feet thick and probably rests on rocks of Paleozoic age. Our preIiminary estimate of the thickness of the rocks of Paleozoic age is 3000 feet, so we estimate the depth to the Precambrian basement as 6000 feet.

Tertiary Rocks. Rocks of Tertiary age in the Gila Hot Springs area, as shown in Figures $2-4$, appear to include:

1. Latitic and Andesitic Flows of Gila Flats [Tgf(?)];

2. Bloodgood Canyon Rhyolite Tuff of Elston (1968) [Tbc]; and

3. Younger Andesitic and Latitic Flows [Tya]. itis

The Latitic and Andesitic flows of Gila flats do not crop out in the Gila Hot springs area, but are inferred in the subsurface. This unit consists of porphyritic latite and andesite flows which may be as much as 600 feet thick in the Gila Hot springs area. Biotite and sanidine from this unit yield potassium-argon ages of $29 \neq 1.1$ million years and $29.3 \pm 1.1$ million years, respectively.

The Bloodgood Canyon Rhyolite Tuff of Elston (1968) consists of ashflow tuffs with abundant quartz and sanidine phenocrysts. This unit crops out and occurs in the subsurface in the Gila Hot 
A

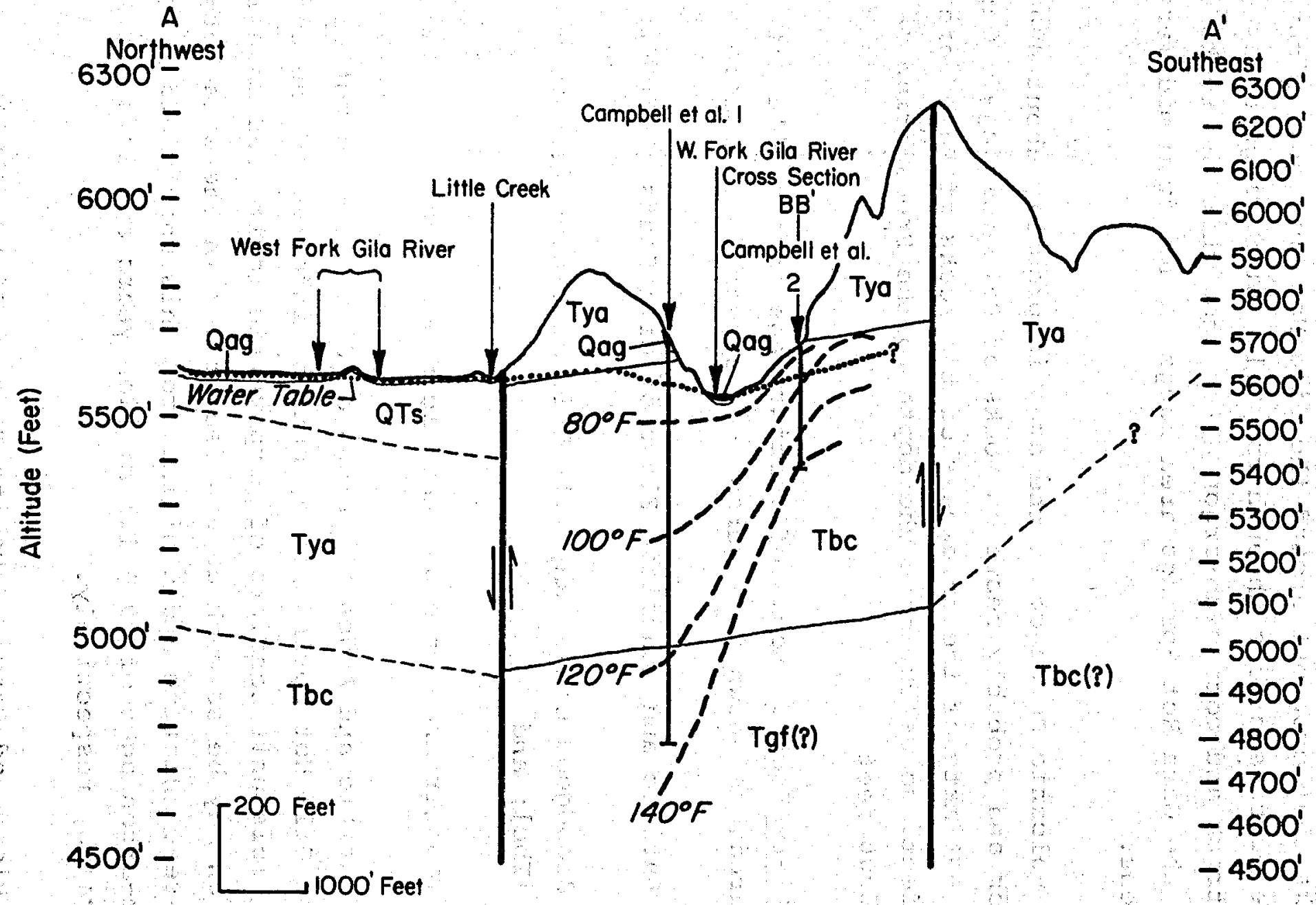

Figure 3. Geologic cross-section AA' showing isotherms near the Gila Hot springs. 


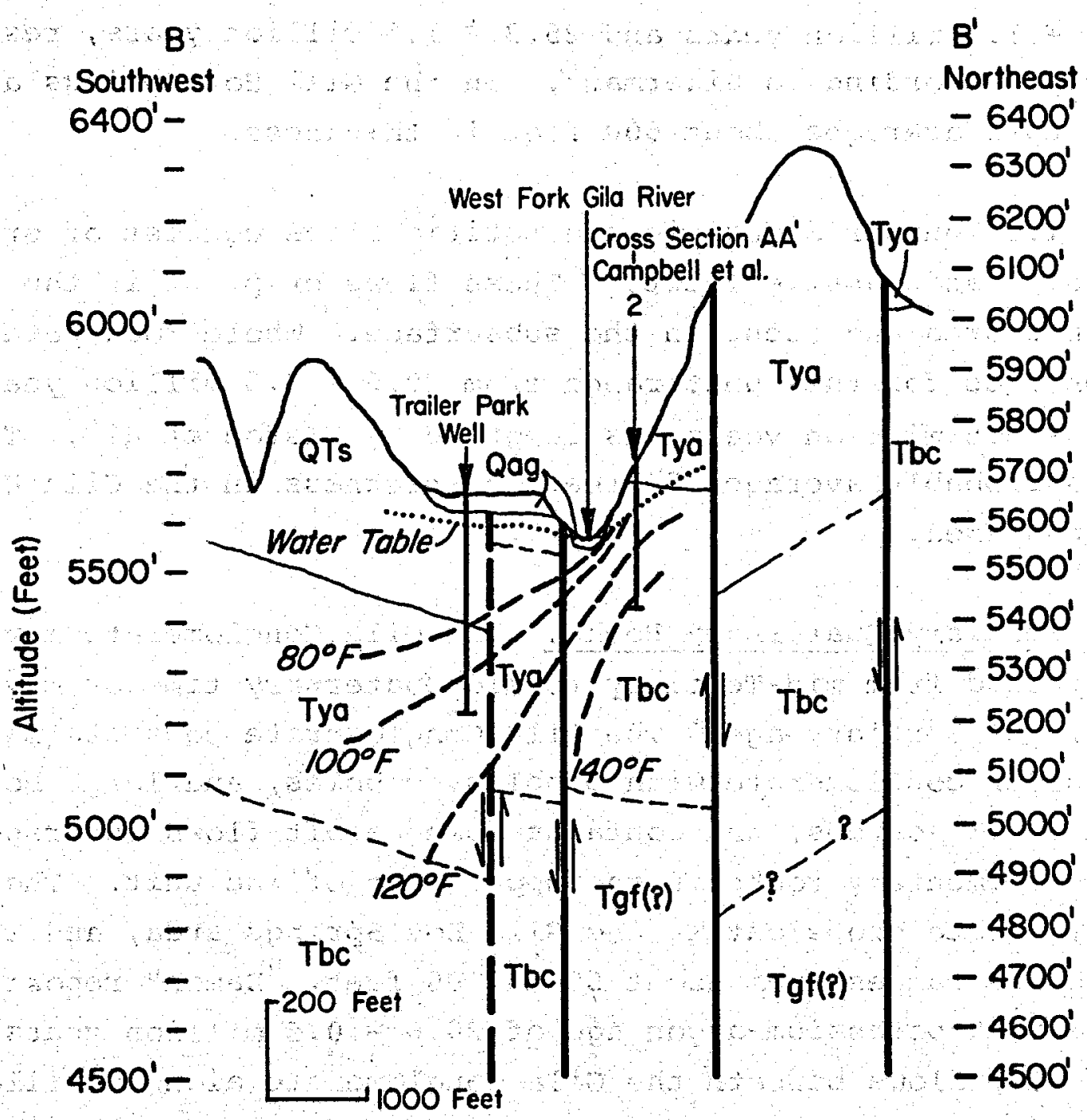

Figure 4. Geologic cross-section BB showing isotherms near the Gila Hot springs. 
Springs area. Well Campbell et al. No. 2 penetrated 271 feet of this rhyolitic tuff, from six feet to the total depth of 277 feet. Biotite and sanidine from this unit give potassium-argon ages of $16.5 \pm 1.5$ million years and $25.3 \pm 1.5$ milition years, respectively, according to Bikerman ${ }^{4}$. In the Gila Hot springs area this tuff averages about 600 feet in thickness.

The Younger Andesitic and Latitic Flows consist of brecciated andesite and massive latite. These flows crop out in the Gila Hot Springs area and occur in the subsurface. Whole rock potassiumargon ages for this unit range from $20.6 \pm 0.5$ million years to $25.0 \pm 0.5$ milizion years, as reported by Elston et al ${ }^{5}$. These flows probably average 450 feet in thickness in the Gila Hot springs area.

Tertiary-Quaternary Rocks. The Gila Conglomerate may span the period from mid-Tertiary to mid-Quaternary time or may be entirely of Tertiary age. The Gila conglomerate consists mainly of a boulder conglomerate with pebbles, cobbles, and large boulders from local sources, and contains some basalt flows interspersed with sedimentary rocks in the upper part of the unit. The Gila Conglomerate crops out in the Gila Hot springs area, and its thickness ranges from about 50 to 400 feet. Damon ${ }^{6}$ reports a whole rock potassium-argon age of $20.6 \pm 0.5 \mathrm{million}$ years for andesitic flows beneath the Gila Conglomerate along sapillo creek. Elston ${ }^{7}$ reports a whole rock potassium-argon age of $6.3 \notin 0.4$ million years for alkali olivine basalt near the top of the Gila Conglomerate along the Mimbres River southeast of the Hot springs area.

Quaternary and Holocene Rocks. Terrace gravels and valley alluvium comprise the youngest rocks in the Gila Hot springs area. The terrace gravels of Holocene age consist of poorly sorted boulders, pebbles, and sand with some silt and clay, deposited in terraces from ten to a hundred feet above the present Gila River bed. The valley alluvium consists of modern gravels, sands, and 
silts in the present Gila River bed and its modern flood deposits. Reported alluvial thicknesses range up to 30 feet at the Gila Cliff Dwellings National Monument headquarters ${ }^{8}$ and 60 feet at the highway bridge near the confluence ${ }^{9}$.

\section{Structure}

Numerous normal faults characterize the structure of the Gila Hot springs area. Most of these faults show dips greater than $70^{\circ}$, strike in a northwesterly direction, and have stratigraphic throws of about 50 to 400 feet.

The Gila cliff Dwellings caldera or the Bursum caldera, both northwest of Gila Hot springs might either one be the source of the Bloodgood Canyon Rhyolite Tuff of Elston (1968) ${ }^{7}$.

The Gila Hot Springs graben (Figure 5) encompasses all the observation points measured during the pumping tests of Well Campbell et al. No. 2. This slightly arcuate structural depression trends north-northwest.

Figure 5 also shows two geophysical anomalies. The magnetic high east of the Gila Hot springs shows about 75 gammas relief, and may represent an intrusive body about 1150 to 1300 feet deep.

The broad, low-amplitude residual gravity high has a closure of about ten milligals. Its axis parallels the Gila Hot springs graben and the anomaly center roughly follows the faulted northern margin of the graben.

\section{Water-Bearing Properties of the Rocks}

Based on their water-bearing properties, the rocks in the Gila Hot Springs area can be divided into three catagories:

\section{Unconsolidated sedimentary rocks;}




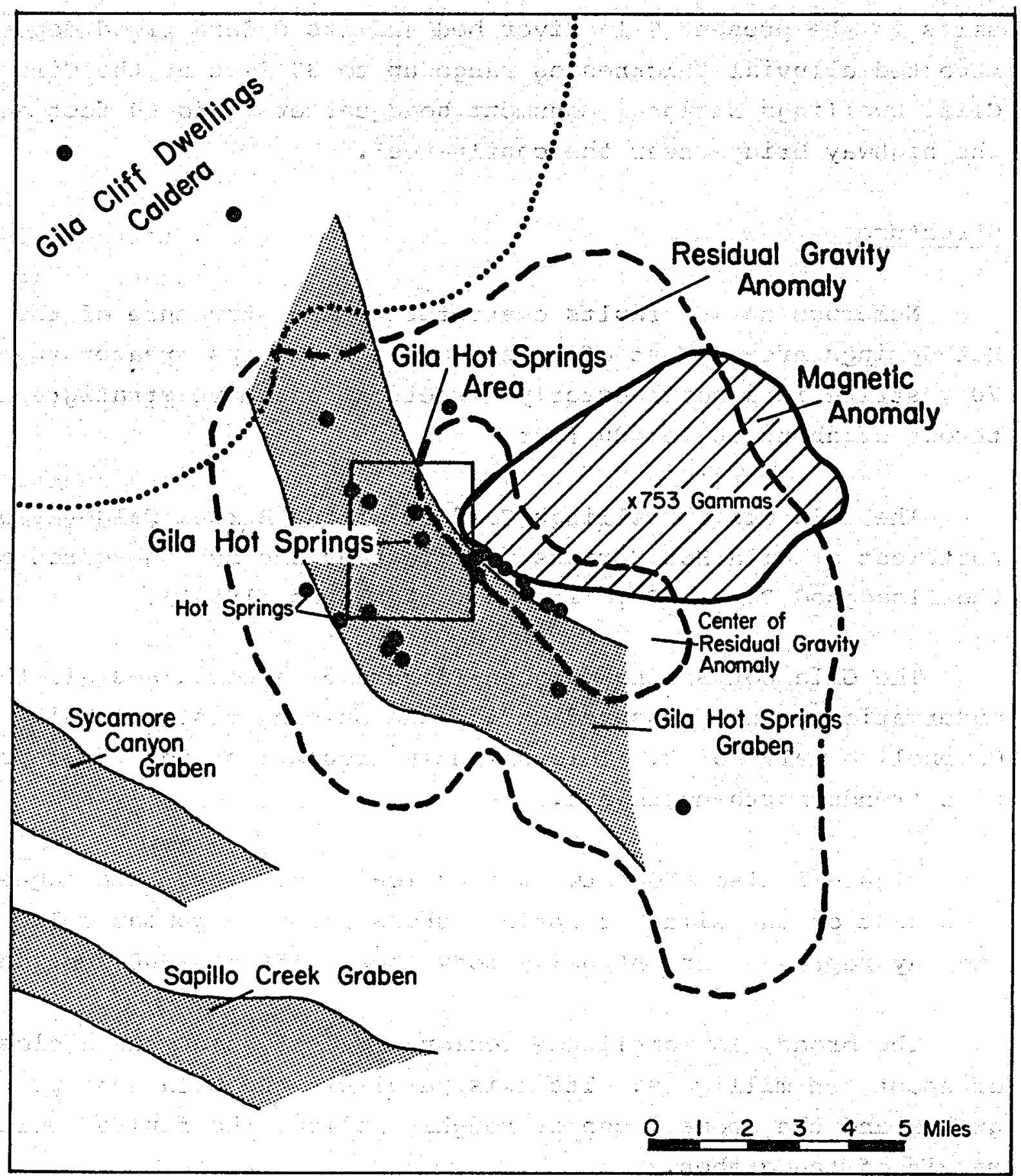

Geophysical Anomalies from Plate 2, Ratté et al (1979)

Figure 5. Map showing the spatial relations among grabens, caldera, geophysical anomalies, and hot springs in the region around the Gila Hot springs. 
2. Semi-consolidated to consolidated sedimentary rocks; and

3. Volcanic rocks.

The unconsolidated rocks include the alluvial terrace deposits, and the modern alluvium. Water (or any other fluid) moves through these rocks by moving through the void spaces between grains. Locally, the rocks are thick enough and saturated enough to yield water to drive points or shallow wells.

The semi-consolidated to consolidated sedimentary rocks include the Gila Conglomerate, some older volcanic-related clastic units, and the underlying rocks of Paleozoic age. The Gila Conglomerate is a major water-yielding rock of southwestern New Mexico. Its hydraulic conductivity, according to Trauger ${ }^{10}$, ranges from 1 to $10 \mathrm{ft}^{3} / \mathrm{ft}^{2} / \mathrm{d}$ in the upper poorly-cemented part and 0.0001 to $0.7 \mathrm{ft}^{3} / \mathrm{ft}^{2} / \mathrm{d}$ in the lower well-cemented part.

The sedimentary rocks older than the Gila Conglomerate are probably all well cemented. Their hydraulic conductivity depends primarily on fractures.

To the best of our knowledge, the hydraulic conductivity of the volcanic rocks depends entirely upon fractures; however, permeable interflow zones may be discovered in deeper wells or test holes.

In essence then--except for the upper part of the Gila Conglomerate and the alluvial gravels-the hydraulic conductivity of the entire rock mass depends upon the size, frequency, and distribution of fractures. So, wells that intersect only a few fractures have lower yields than wells that intersect extensively fractured zones. 


\section{INSTRUMENTATION}

\section{Discharge Measurements}

\section{Flow Meter}

A totaling flow meter with a needle-type flow-rate indicator was used to measure discharge from Well Campbell et al. No. 2 during both these pumping tests. We used the rate shown by the needle for field reference, but determined actual discharge rates by recording the metered volume at several times and calculating the rate.

Tables $C-2$ and $D-1$ contain the meter readings and calculated discharge values for the step test and the constant-rate test, respectively. The "incremental" discharge rates in these tables suggest that some recorded meter readings may not be correct, but the averages determined for each step and for the constant-rate test probably are correct.

We believe this meter is accurate to \pm 28 of the recorded discharge rate.

\section{Flumes}

We set two modified Parshall flumes to measure the discharge of springs. These flumes were designed to measure flows from about 1 to $500 \mathrm{gpm}$. One flume is aluminum, the other plastic, but both are constructed to the same specifications. For maximum accuracy such a flume should be installed in the straight part of a stream with the upper surface of the flume level both perpendicular and paraliel to the direction of flow. Properly installed, these flumes are accurate to about $\pm 0.5 \mathrm{gpm}$ at the discharge rate of flume-site $1 \mathrm{~A}$ and to about $\pm 0.7 \mathrm{gpm}$ at the discharge rate of flume-site 2 . 


\section{Depth-to-Water Measurements}

Two steel tapes and two water-level monitors were used to measure the depth to water in the pumping well (Well Campbell et al. No. 2) and two observation wells (North Well and South Well).

During the step test one water-level monitor and one steel tape were used at the pumping well while the other water-level monitor was used in one observation well (South Well) and the other steel tape was used at both observation wells.

During pre-test measurements for the constant-rate test, the water-level monitor in use at the pumping well failed, so the other water-level monitor was removed from the South well and used in the pumping well. After that change, the same steel tape was used for all measurements in both observation wells.

\section{Steel Tapes}

Two steel tapes were used for depth-to-water measurements. These are both surveyors tapes graduated in feet, tenths of feet; and hundredths of feet.

The steel tape used at the pumping well is about 300 feet long, with numbered markings every foot and one foot marked in tenths and hundredths of a foot every hundred feet. A wooden folding rule fully graduated in tenths and hundredths of feet was used to increase the accuracy of measurements with this tape.

The tape used at the two observation wells is only about 75 feet long, but is fully graduated in tenths and hundredths of feet.

To measure water level with a steel tape, one first assigns a measuring point (commonly a mark on the exposed top rim of the well casing) from which all measurements are made. (Noting the 
height of this measuring point, above or below the land surface, allows calculation of water level altitude if the land surface altitude is known.) Next one lowers the tape into the well until the lower end is below the water surface. (This may require a few tries, but becomes easier with successive measurements.) After noting the time and exact footage mark that corresponds to the assigned measuring point when the tape's end is wet, the tape is reeled up until the wet end is visible. One then notes the exact footage wet and calculates the depth to water by subtracting the footage of wet tape from the total footage lowered into the well:

For example: if the mark for 30.00 feet is lowered to the measuring point at 1003 hours and the tape is wet to 10.43 feet after immediate retrieval, the depth to water from the measuring point was 19.57 feet at 1003 hours.

The chalked-tape method of measurement was used with the steel tapes at all wells. This method uses blue carpenter's chalk (readily available in easy-to-hold hemispherical pieces). The chalk is rubbed over the lower few feet of the tape before the tape is unreeled into the well. The chalk changes from pale blue to dark blue when wet, making the exact line to which the tape was wetted more distinct.

Under ideal conditions, we expect precision of \pm 0.02 feet and accuracy of the same level from chalked steel tape measurements of depth to water.

If a steel tape gets hung up but reaches the water surface the depth to water determined from that measurement will be too large. Sometimes a steel tape stored on a reel retains some curvature when unreeled; when this happens the depth to water measured with that particular steel tape will be slightly larger than the actual depth to water.

If the tape rubs something within the well, such as the 
electrical cable for the pump, the pump column, or the side of the hole, that will smear the mark. If the interfering object is wet, it may create a false mark that results in an apparent depth to water which is too small (is shallower than the actual depth to water.) Water cascading into a well, whether from fractures in the wall of an open hole or from slots in casing, can also wet the tape before it reaches the true water level, thus producing a depth-to-water measurement that is too small.

If surging occurs in a well, the actual water surface will rise and fall with the surges and may fluctuate wildly within a very short period of time.

Observation of the discharge just before turning the pumps off during the constant-rate test $(47.5$ hours into the 48 hours of pumping) suggested that surging was occurring - at least at the end of the discharge pipe. If any of the people who saw the discharge between 100 minutes and 2850 minutes into the constantrate test noticed surging, they did not mention it. Therefore, we cannot clearly relate the phenomena to variations in the depth-to-water measurements. similarly no one noted surging during the step test. Meter readings may record fluctuating discharge rates that often accompany surging; they could also reflect the difficulty of reading the turning dials of the meter.

Figure 6 illustrates steel-tape measurements under ideal conditions, and with some problems. For comparison, the diagrams show a properly-installed water-level monitor probe in the same wel1.

All three people who made steel-tape measurements in Well Campbe1l et al. No. 2 during these pumping tests mentioned hangups. The variability of steel-tape depths to water (Appendix $c$, Tables $C-3$ and $C-4$; Appendix $D$, Tables $D-2$ and $D-3$ ) indicates that some hang-ups probably escaped notice at the time of the measurement. 


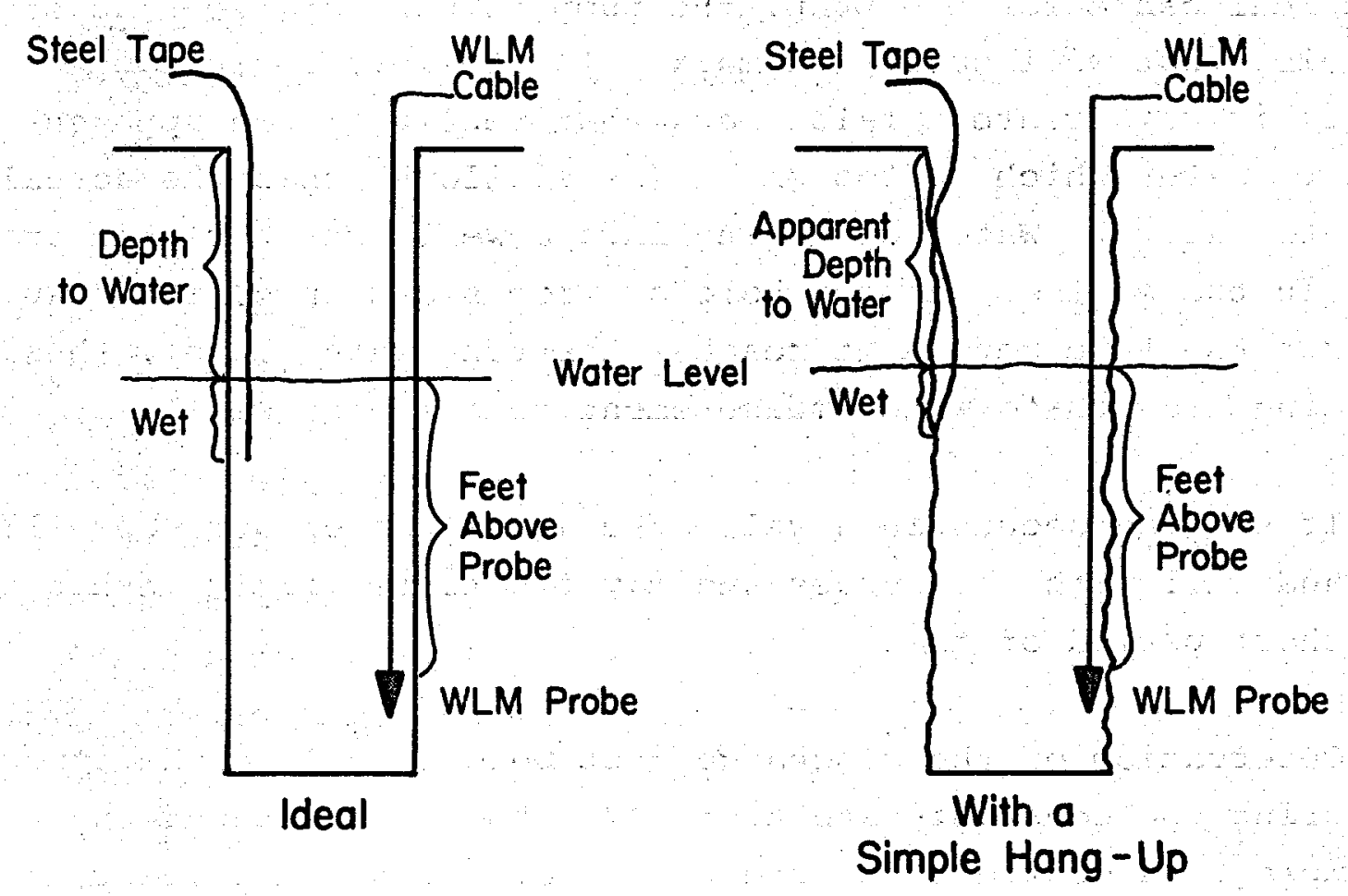

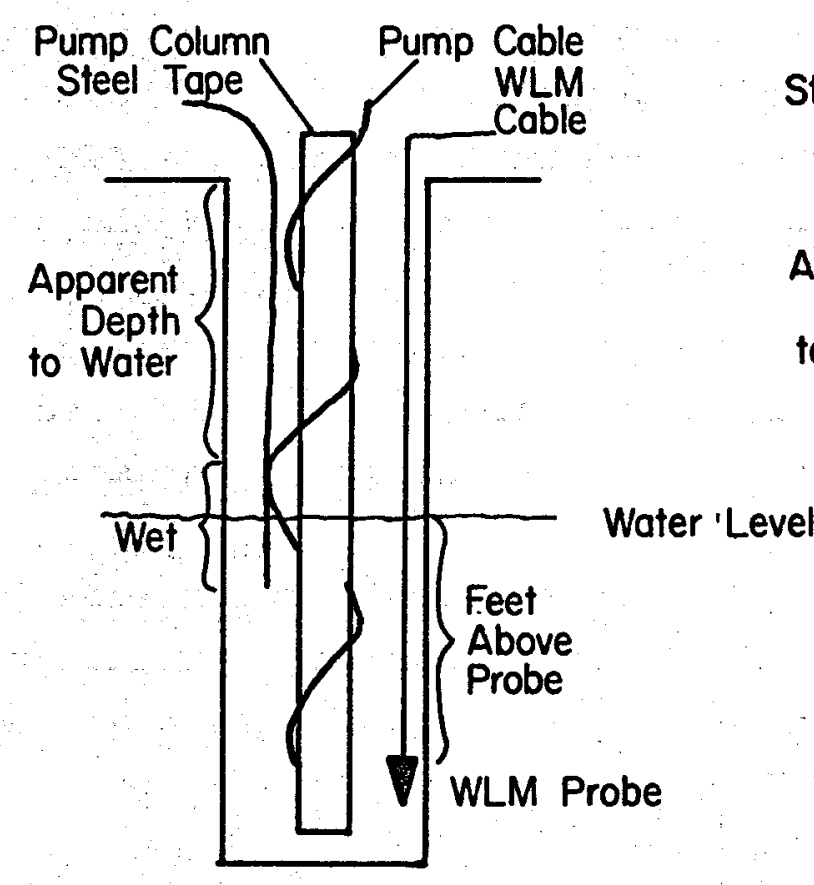

With Wet Interference

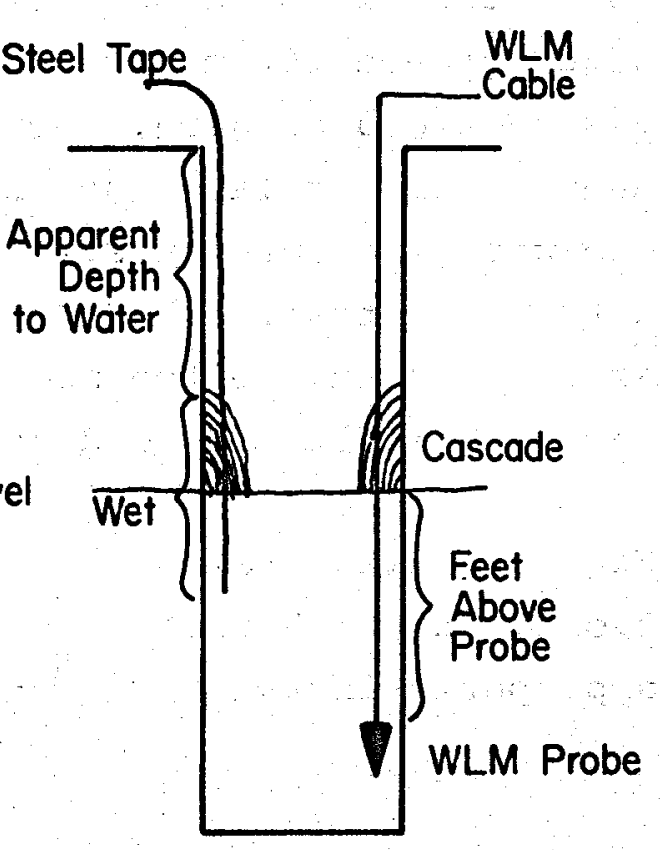

With a Cascade

Figure 6. Diagrammatic illustration of some problems encountered during depth-to-water measurements. 
Many marks were smeared during these tests (Tables $c-3$ and $c-4$, $D-2$ and $D-3$ ) and these measurements may be quite inaccurate.

Water-Level Monitors

The water-level monitor uses a pressure-sensitive transaucer to determine the height of the column of water above a probe lowered into the wel1. The probe is left at that same depth throughout the measurement period. Electrical cable carries a signal from the transducer to components that convert the pressure sensed by the transducer to equivalent feet of water above the probe. At the surface, a small box-like device with a digital display shows the reading as feet of water to the nearest tenth of a foot. knowing the total distance from the probe to the measuring point, the depth to water can be determined by subtracting the feet of water above the probe from the depth to the probe:

For example, if the total distance from the probe to the measuring point is 227.83 feet and the water-level monitor shows 101.5 at 1500 hours, the depth to water from the measuring point is 126.3 feet at 1500 hours.

Since these instruments require at least two hours to adjust to well conditions, the pre-test measurements include intermittent measurements made with chalked steel tapes at the same time we: recorded the readings from the water-level monitors. These measurements allow the operator to separate instrument arift from water-level changes.

Under ideal conditions, the water-level monitor could give precision of $\neq 0.1$ foot. As far as we can determine, ideal conditions never persist throughout an entire test.

As mentioned above, this monitor uses a pressure-sensitive transaucer. The transducer neither knows nor cares what causes 
the pressure on it to change. An increase or decrease in atmospheric pressure will cause a corresponding increase or decrease in the water-level monitor reading. Under stable weather conditions, or during short-term tests with rapidly changing depth to water, apparent water-level changes due to changing atmospheric pressure will be very small compared to actual changes of depth to water. However, during unsettled weather, or during long-term constant-rate tests with gradually changing depth to water, apparent water-level changes due to changing atmospheric pressure might significantly affect data interpretation.

The water-level monitors are powered by dry-cell batteries, and batteries commonly deliver slightly different voltages at different temperatures, so atmospheric temperature extremes can create berrant readings because of variation in power supply. Batteries also discharge more rapidly when cold, which allows the rate of change in the power supply to vary. New Mexico's typical $30^{\circ} \mathrm{F}$ to $40^{\circ} \mathrm{F}$ diurnal temperature range creates a need for intermittent calibration measurements with some other instrument to allow correction of the water-level-monitor reading for the effects of environmental temperature changes.

Electronic components respond to temperature also: some conduct more readily at elevated temperatures, some conduct less readily at elevated temperatures, and some apparently show little change with temperature unless the temperature remains elevated (or depressed) for a long time.

We use the term "drift" to refer to apparent water-level changes that result from water-level monitor responses to stimuli other than changing depth to water.

\section{Cross-Checks}

When both a water-level monitor reading and a steel-tape measurement are made simultaneously in a well, one determines both the depth to water (steel tape) and the depth of water above the water-level monitor probe at that time. The sum of these 
measurements equals the depth of the water-level monitor probe below the measuring point. Because the water-level monitor probe remains at the same depth during an entire test, the sum of these measurements should be constant throughout the test. (Any change in the depth to water changes the value of each measurement, but the changes balance each other and the sum of the measurements remains constant.) Therefore, use of simultaneous measurements allows correction of the water-level monitor readings without requiring detailed knowledge of temperature and pressure changes experienced or exact effects of those changes upon the waterlevel monitor.

During these tests of well Campbell et al. No. 2, the sum of steel tape and water-level monitor readings did not remain constant at Well Campbell et al. No. 2. This shows that inaccuracies exist in one or both types of measurements. (On the other hand the sum of steel tape and water-level monitor readings remained nearly constant at the south well during the step test, showing that both types of measurements there were relatively accurate.)

After studying all available data, we believe that all the problems with depth-to-water measurements mentioned in preceding paragraphs occurred during the pumping tests of well Campbell et a1. No. 2. The depths to water computed in Appendices C and D represent our best attempt to correct the water-level monitor readings for drift by correlating them with the most plausible (least suspect) of the steel-tape measurements.

\section{Water Temperature and Chemistry}

\section{Temperature}

Water temperature was measured with two thermometers. One is liquid (presumably alcohol) in glass with two-degrees Fahrenheit graduations. The other is mercury in glass, marked with both one-degree celsius graduations and two-degrees Fahrenheit grad- 
uations.

The Fahrenheit-only thermometer was kept at Well Campbell et al. No. 2 throughout the tests and used for routine temperature measurements there.

The celsius-Fahrenheit thermometer was used for in-situ temperature measurements at some of the hot springs, for two check measurements at Well Campbell et al. No. 2, and for measurements with field chemical analyses.

After water samples had cooled below $50^{\circ} \mathrm{C}$, we also made temperature measurements with the thermometer that is built into the specific conductance probe. We used that temperature to adjust the instrument and to convert the specific conductance measured to the standard reference temperature of $25^{\circ} \mathrm{C}$.

Measurements of the temperature of well water made with the two liquid-in-glass thermometers were the same. Their accuracy is about $0.5^{\circ} \mathrm{C}$.

During pumping, temperatures of the discharging water from Well Campbell et al. No. 2 were measured with a thermometer inserted into the plastic discharge pipe through a drilled hole just large enough to admit the thermometer.

During the step test, and during the first few hours of the constant-rate test, the thermometer was constantly in place in the discharge line. Later in the constant-rate test, the line showed evidence of collapsing, so the thermometer was removed. This allowed air to enter the line freely and thereby reduced the suction that was collapsing the pipe. To measure the temperature, the observor then had to insert the thermometer, wait for it to stabilize, read the temperature, and remove the thermometer again before the line collapsed. This measurement operation required judgement by the operator to determine how long the thermometer 
needed to remain in the line. Some temperatures may be about one degree celsius too low because of this measurement procedure.

\section{Specific Conductance}

Specific Conductance was measured with a YSI Model 33 salinity-conductivity-temperature meter. In the range of measurements made during this test, the precision of this instrument is about \pm 10 umhos $/ \mathrm{cm}$ at $25^{\circ} \mathrm{C}$.

\section{Silica}

Field determinations of silica employed a Hach Chemical Co. "Engineers Portable Water Laboratory" Model DR-EL colorimeter and used the silicomolybdate powder method of analysis. silica determinations with this instrument and method tend to be about 30 percent, lower than when the same sample is analysed at the same time by atomic absorption flame spectrophometer techniques.

\section{Carbonate and Bicarbonate}

Field determinations of carbonate and bicarbonate were made by titrating a measured volume of water with $0.02 \mathrm{~N}$ sulfuric acid to a pH of 4.5. Accuracy of these measurements is about $\pm 1 \mathrm{mg} / 1$ at the concentrations measured.

$\underline{\mathrm{pH}}$

Field determinations of $\mathrm{pH}$ were made with a cole-parmer Digisense portable $\mathrm{pH}$ meter. This instrument has a digital display which allows the operator to read pH to the nearest $0.01 \mathrm{pH}$ unit. This battery-operated instrument with sealed combination electrode does require more attention from the operator than a typical laboratory model, but we believe these determinations are accurate to $\neq 0.1 \mathrm{pH}$ unit. 
TEST PUMPING PROGRAM

\section{Program Summary}

The test pumping program includes:

1. Pre-test measurements;

2. A 5-step test;

3. A 48-hour constant-rate test with 60 hours of recovery; and

4. Collection of water samples for detailed chemical analysis.

\section{Pre-test Measurements}

Pre-test measurements included measurements of depth to water in Well Campbell et al. No. 2 and the North and South observation wells, and measurements of spring discharge at two sites.

D.A. Campbell's crew installed the pump in Well Campbell et al. No. 2 on October 6, 1981 before installation of the waterlevel monitor. They also ran about 350 feet of discharge pipe down the canyon to reduce the chances of water discharged from the well flowing via fractures and/or interstitial pores from the surface to the water table and being repumped.

One water-level monitor was installed in Well Campbell et al. No. 2, and another in the South Well. The water-level monitor uses a pressure-sensitive transducer to determine the height of the column of water above a probe which is lowered into the well and left at that same depth throughout the measurement period. since these instruments require at least two hours to adjust to 
well conditions, the pre-test measurements include intermittent check measurements made with chalked steel tapes at the same time the water-level monitors were read.

Two sites were chosen at which to monitor spring discharge during the pumping tests. since flumes were to be used to measure discharge, these sites had to have water flowing on the ground rather than "collected" to flow through a box or pipe into the domestic supply system. These sites were also chosen at opposite ends of the line of springs to give geographic distribution and temperature variation. Idealiy, these same sites would have been used to collect samples of spring water for chemical analysis, but the sites most suitable for properly setting a flume were not those most suitable for sample collection. Therefore, a sample was collected from the most suitable sample point of similar temperature near each of the two flume sites.

After Doc Campbell discussed the discharge arrangement with us we moved one flume out of the drainage downhill from the well's discharge to a site with lower flow but less apt to be influenced by runoff from the test's discharge. (Appendix B, Tables 1, 2, and 3 , present all flume measurements made before and during these pumping tests.)

As mentioned earlier, water samples were collected from two springs, one near each flume, before pumping began for the step test. Sample bottles were placed near each flume so that another sample could be quickly collected if the spring flow decreased during the test. Table 1 presents all field analyses of water samples collected for these pumping tests.

Figure 7 is a sketch showing the points at which measurements were made before and during the pumping test of well Campbell et al. No. 2. This is not a detailed map: it shows only a few of the many hot springs, a few of the man-made additions, and no trees, shrubs, boggy areas, or steep slopes. 


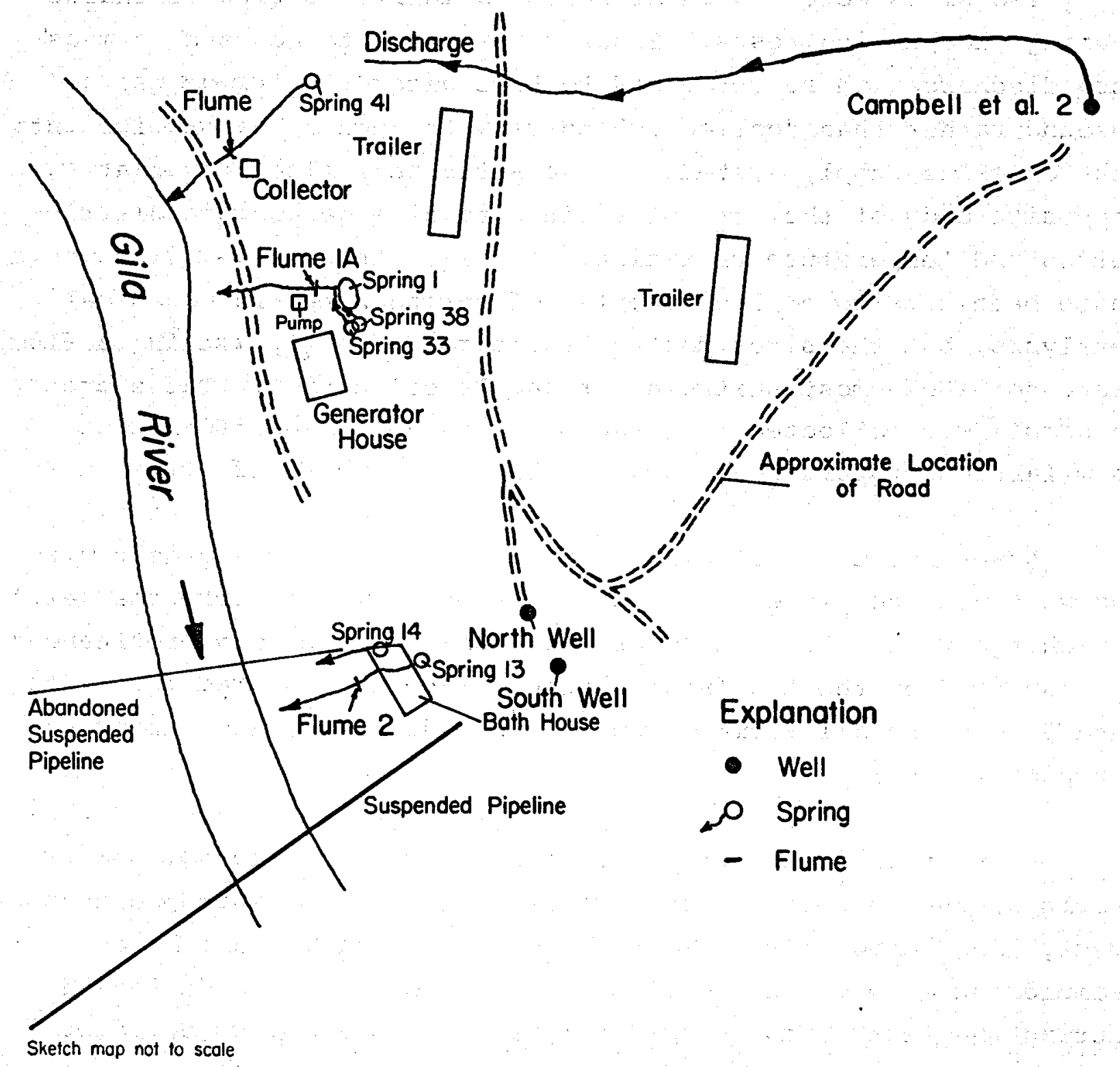

Figure 7. Sketch showing relative locations of well Campbell et al. No. 2 and observation points used during October 1981 pumping tests. 
The distance from Well Campbell et al. No. 2 to the North Well is 482 feet; and to the South well is 496 feet. The distance between the North and south Wells is 30 feet.

\section{Step Test}

The step test of Well Campbell et al. No. 2 consisted of five pumping steps, each of thirty minutes duration, preceded by background measurements from the time of pump installation until turn on, and followed by measurements of recovery from the time the pump was turned off until time to prepare for the next test.

Besides measurements of depth to water, discharge rate, and temperature of the discharging water at the pumping well, we measured depth to water in two observation wells about 500 feet from the pumping weli, and measured the discharge rate of the springs at two locations.

We used a pressure-sensitive transducer to measure the water level at the pumping well, and another one at the south observation well. At the North observation well, we measured the depth. to water with a chalked steel tape.

We used two modified Parshall flumes placed in small streams carrying runoff from one or more springs of the Gila Hot Springs. We placed the flumes as close as practical to the two springs that we sampled before the test began.

The frequency of measurements varied with the expected response: we measured the pumping well more frequently than the observation wells, and the observation wells more frequently than the flumes.

During the pumping period, measurements at the pumping well were made 15 seconds apart immediately following turn-on and immediately following each increase in discharge, and were contin- 
ued at less frequent intervals throughout pumping. Immediately after the pump was turned off, we again made measurements of depth to water at 15-second intervals, then gradually increased the time between measurements until the total time since pump off was equal to twice the pumping time, at which hour we reduced the frequency of measurements to once every four hours.

At the two observation wells, we measured the depth to water every two minutes from the time the pump turned on until $30 \mathrm{~min}-$ utes after the pump was turned off. We then gradually decreased the frequency of measurements until the elapsed time since pump off was equal to twice the total pumping time, at which hour we further reduced the frequency of measurements to once every four hours.

At each of the two flumes we recorded the height of water in the flume throat every five minutes during pumping and for the length of one step (30 minutes) after turning the pump off. We then gradually increased the time between measurements until the elapsed time since pump off equaled twice the pumping period, at which point we switched to measuring the flumes once every four hours.

Data collected at the wells during the step test are tabulated in Appendix $C$, Tables $\mathrm{C}-1$ through $\mathrm{C}-11$. Data from the flumes appear in Appendix B, Tables B-2 and B-3. For the sake of brevity, these tables omit some measurements of depth to water, especially those recorded from the water-level monitors when the numbers did not change for several consecutive readings. All flume readings, and all flow-meter readings, have been included in the appropriate tables.

\section{Constant-Rate Test}

Before pumping Well Campbell et al. No. 2 for the constantrate test, we attempted to increase the maximum discharge rate 
possible by installing a centrifugal pump in the discharge line. D.A. Campbell has used two centrifugal pumps in tandem to increase the discharge rate, and we hoped that using the centrifugal pump would decrease the effective back-pressure against the submersible pump and allow the two pumps to deliver at a slightly greater rate than was possible with the submersible alone. No increase in discharge resulted from this experiment.

Background measurements of depth-to-water in the observation wells and the pumping well, and of discharge through the flumes from springs, preceded the constant-rate test, which ran for 48 hours at maximum discharge for the pumps and plumbing in use.

Measurements of depth to water in the pumping well initially were recorded every 15 seconds, then with gradually decreasing frequency until the interval between readings was 30 minutes. When we turned the pump off, we again made frequent measurements while the depth to water was changing rapidly, then measured less frequently as the depth to water approached a steady state. The last measurements were made at four-hour intervals, the final measurements being made 60 hours after the pump was turned off.

- Measurements at the observation wells and flumes were made once every half hour auring the first 1000 minutes of pumping, then once every hour until about 12 hours after the pumps were turned off, then once every two hours until about 22 hours after the pumps were turned off, then once every four hours until 60 hours after the pumps were turned off.

Flow-meter readings were recorded during pumping.

Appendix $D$, Tables $D-1$ through $D-10$ show the measurements and calculations made for the constant-rate test. 


\section{Water Samples}

Collection of water samples began with two springs, as mentioned before. These springs were chosen to provide contrasts in temperature and location, and to be easily sampled.

One was toward the northern end of the spring area, the other toward the southern end. The sample at the southern end was collected from a pipe discharging from a box-like collector in the northwest corner of the old army bathhouse (\#14). The sample at the northern end was collected from an open discharge point in the plastic piping from a cemented-crevice collector (\#41). The collector is on the east bank of a tiny stream that discharges to the West Fork Gila River through a tile culvert north of the generator house. (See Figure 7 for locations.)

Five other samples were all collected from Well Campbell et al. No. 2 during the constant-rate pumping test. We spaced collection of these samples throughout the test to document any chemical change that might occur. The first of these samples was collected after 15 minutes of pumping, the second after 100 minutes, the third after 1000 minutes, the fourth after 1500 minutes, and the fifth and last, after 2850 minutes. (Test duration was 2880 minutes.)

When time and personnel allowed, partial chemical analyses were performed in the field on samples collected from the same place at the same time as those submitted for detailed analysis. These field analyses for the two spring samples and the first two well samples appear in Table 1 .

If either flume showed a significant response to pumping, another sample would have been collected from the spring nearest the responding flume. Since neither flume showed a response, neither spring has a second sample. 
TABLE 1. FIELD MEASUREMENTS FOR WATER SAMPLES COLIECTED DURING PUMPING TESTS OF WELL CAMPBELL ET AL. NO 2

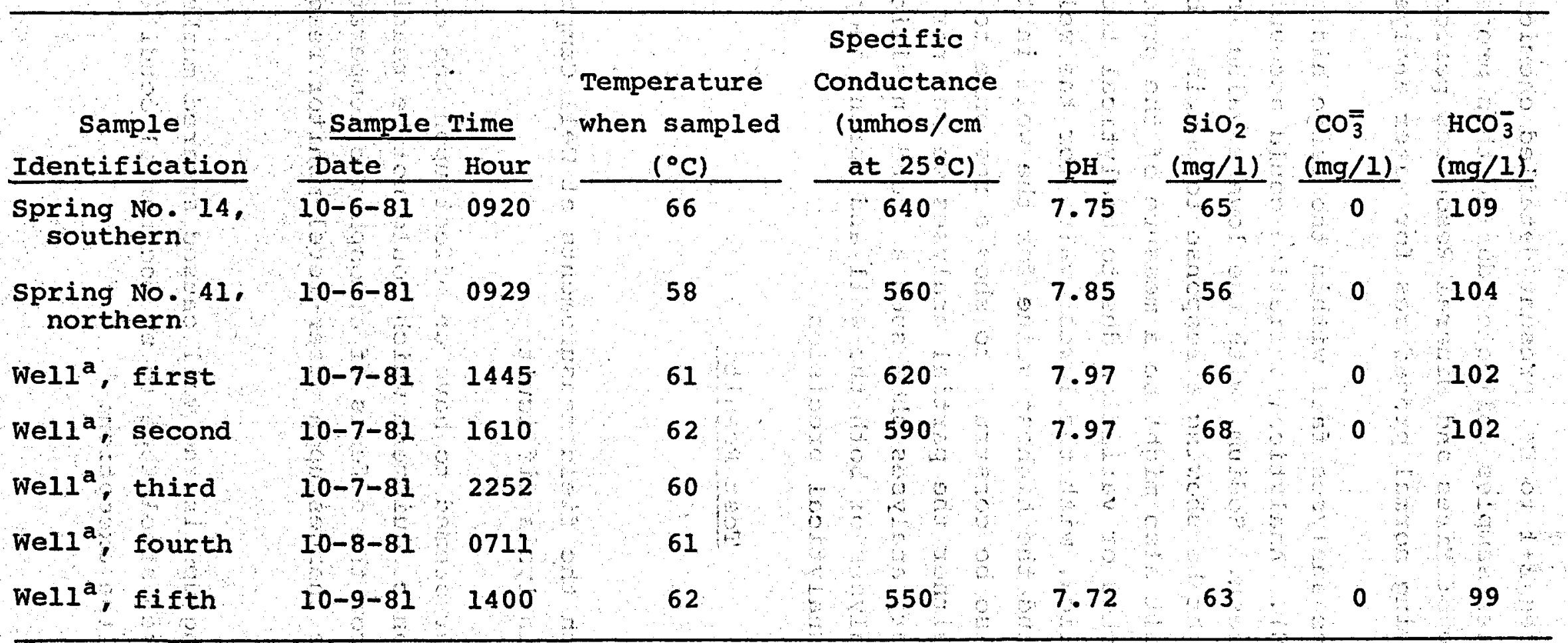

a. Well Campbell et al. No. 2, 135.13 W. 5.212 ; temperature measured in discharge line at well site. 
Appendix E, Tables E-1 to E-7 present detailed chemical analyses of the seven water samples collected during this project. The New Mexico Bureau of Mines and Mineral Resources performed these analyses following normal procedures for water analysis.

In general, these analyses fall within the range historically reported (Reference 8). Analytical variation could account for all the differences seen. Sodium, with the lowest value in the last well sample, might be showing a response to pumping, but this single anomalous result also might be a measure of the precision of the analytical method or variation due to analytical technique of the operator. Silica, with the lowest value for the well in the earliest sample and the highest value for the well in the last sample, might also be construed to show a response to pumping. However, neither the partial analyses we ran nor the intermediate laboratory analyses show such a trend in silica content, and all the analyses of both the well and spring samples are within the range of analytical precision.

\section{Test Results}

\section{Data Interpretation}

Two problems with the field measurements at well campbell et al. No. 2 made data analysis difficult:

1. The hot water seemed to have an effect upon the downhole electronic equipment which could not be readily separated from the effects of atmospheric temperature and pressure changes upon water-level-monitor readings, and

2. Numerous hang-ups in the well caused smeared marks on the chalked steel tape to be the normal condition rather than the exception. 
Overview

Figure 8 shows the relationship of drawdown, discharge, and temperature of discharging water at well Campbell et al. No. 2 during the period from 1500 hours on October 5,1981 to 0230 hours on october 12,1981 .

\section{Step Test}

Figure 9 plots data from the step test pumping of Well Campbell et al. No. 2 on October 6, 1981 with specific drawdown (s/Q) or specific drawdown adjusted for Jacob's correction (s'/Q) 11 versus the logarithm of adjusted time ${ }^{12}$ or Harrill's argument ${ }^{13}$. (See Appendix $\mathrm{H}$ for more details.) From this plot we calculated a transmissivity (T) of 13,900 gallons per day per foot (gpd/ft), which gives a hydraulic conductivity (K) of about $80 \mathrm{gpd} / \mathrm{ft}^{2}$ if we assume a thickness of 170 feet (the depth of open hole below the pre-pumping water surface during this test).

Figure 10 shows specific drawdown adjusted for Jacob's correction versus discharge for Well Campbell et al. No. 2 during the step test on october 6, 1981. As shown, the five points fit a straight line with a slope of $0.0047 \mathrm{ft} / \mathrm{gpm}^{2}$. The slope of this line is called $c$, the well's coefficient of inefficiency.

Appendix B, Tables $B-2$ and $B-3$, and Appendix $C$, Tables $C-6$ through C-11, present data for the observation points during the step-test pumping of Well Campbell et al. No. 2 .

\section{Constant-Rate Test}

Figure 11 plots $s^{\prime} / Q$ or $s / Q$ versus the logarithm of elapsed time (during pumping) or $t / t^{\prime}$ (during recovery) for the 48-hour constant-rate pumping test of well campbell et al. No. 2. BY drawing a straight 1 ine through the data for 100 to 1500 minutes of elapsed pumping time, we obtain a $T$ of $13,900 \mathrm{gpd} / \mathrm{ft}$, the same 

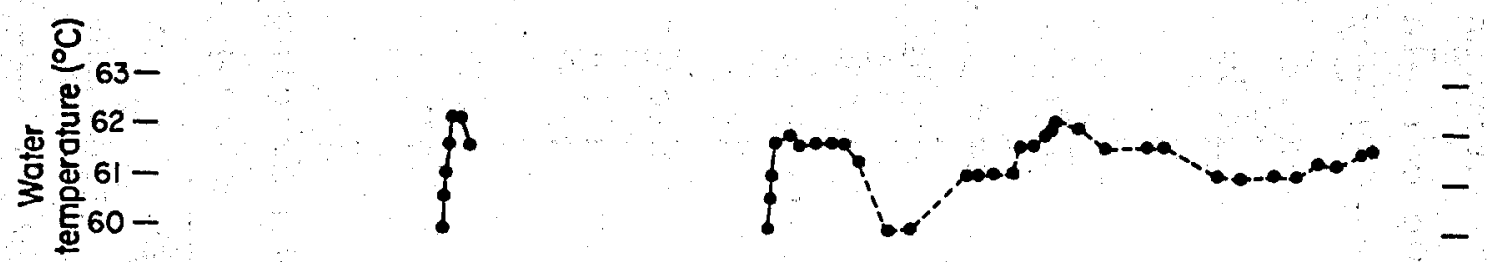

$30-$

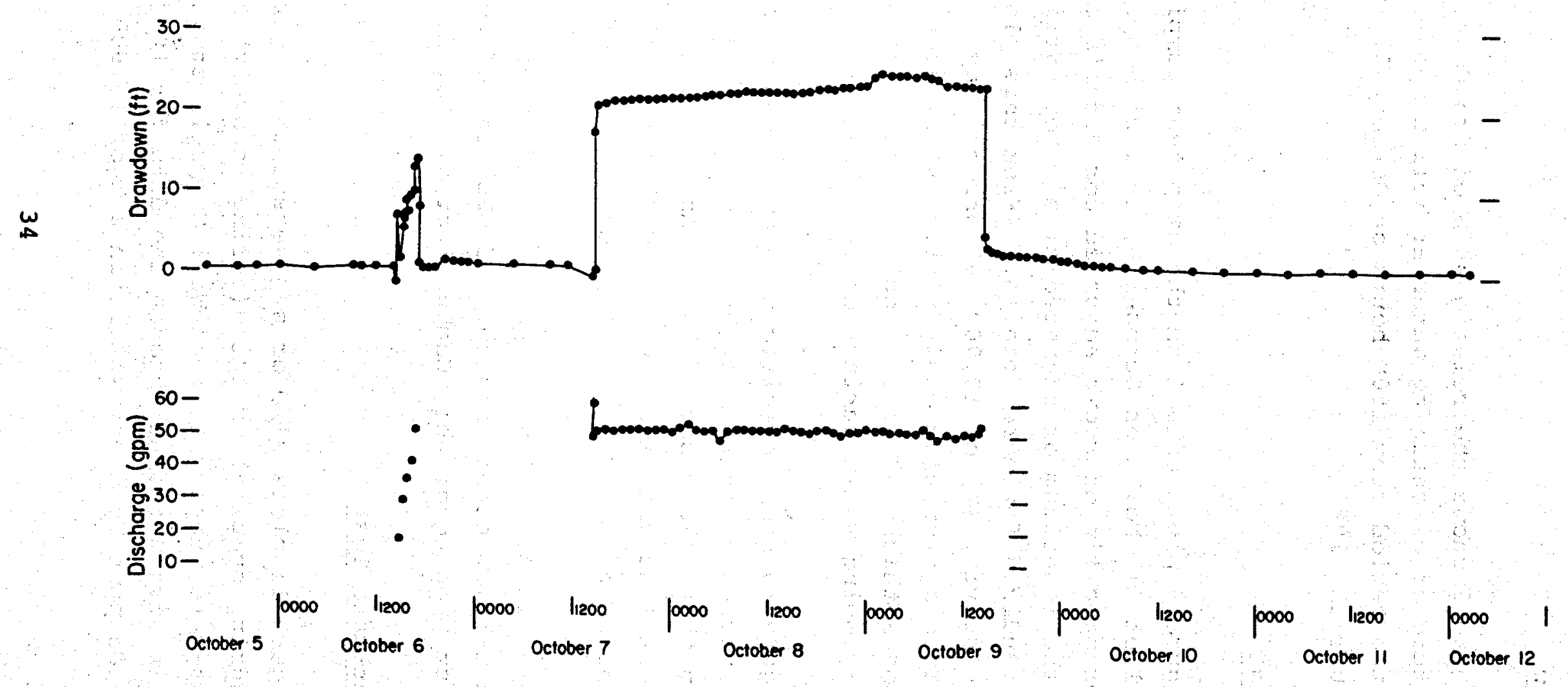

Figure 8. Drawdown, discharge, and temperature of discharging water at well campbell et al. No. 2, October 5 to October 12,1981 . 


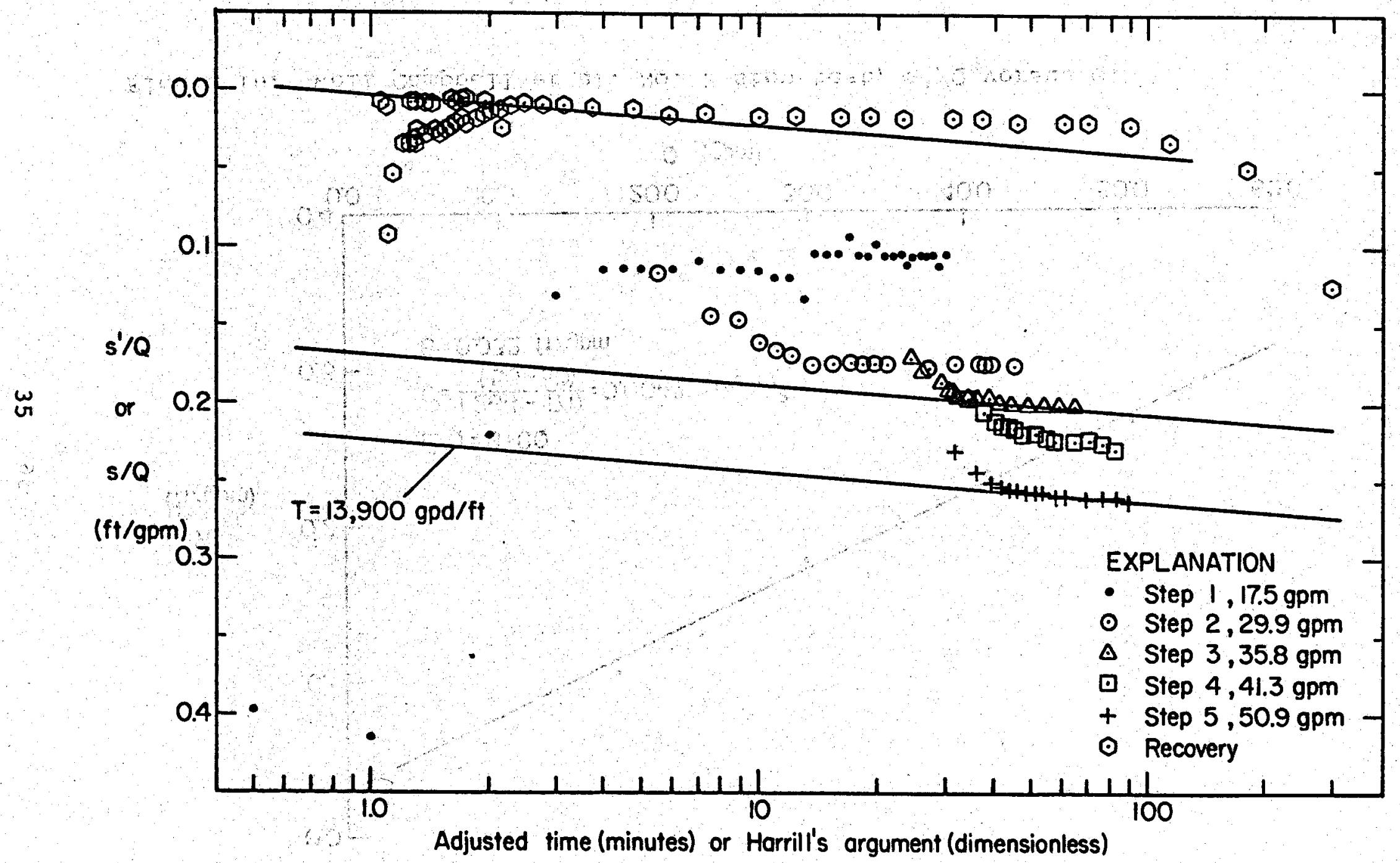

Figure 9. Well Campbell et al. No. 2 step test, s'/Q or $s / Q$ versus adjusted time or Harrill's argument. 
$\omega$

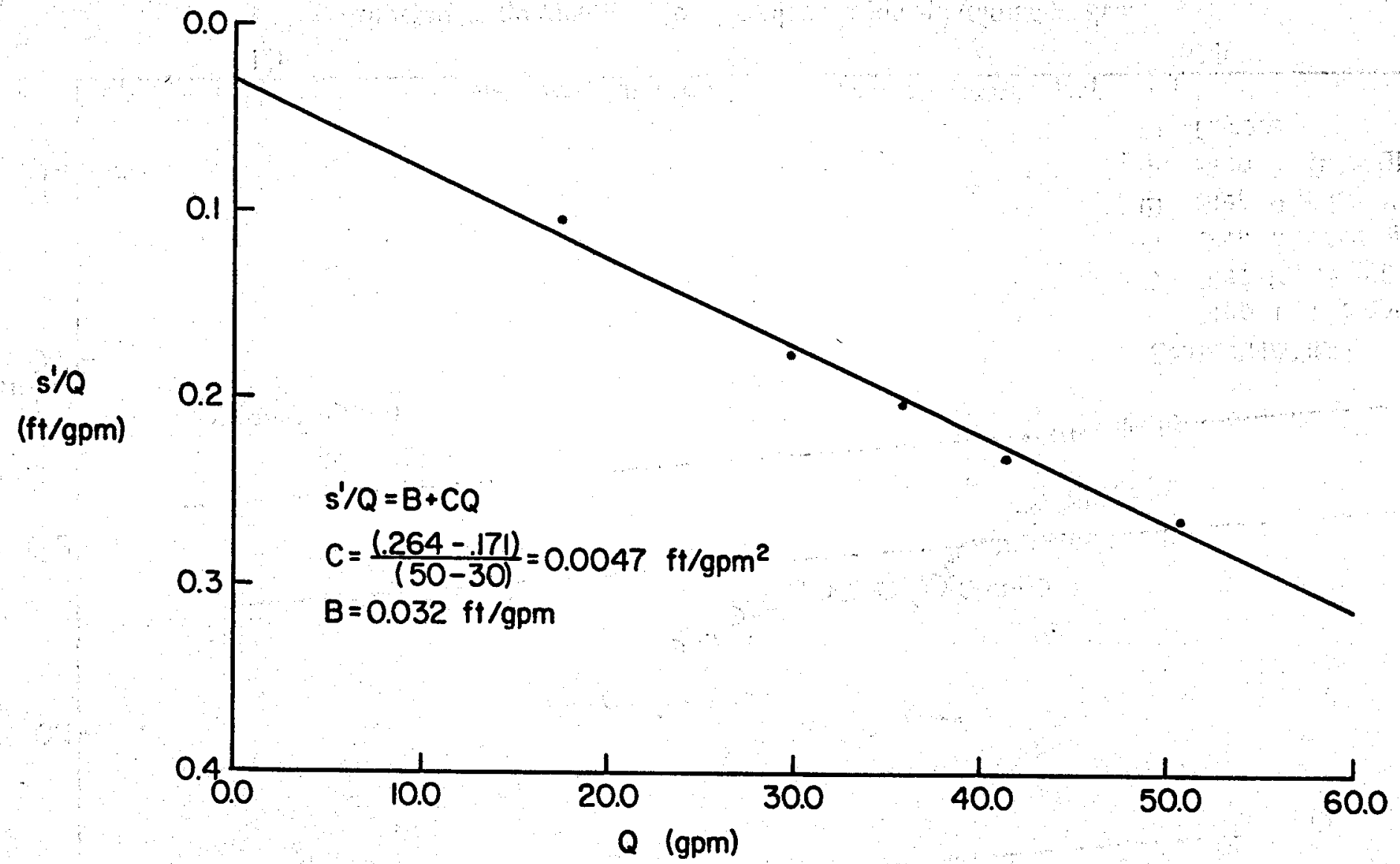

Figure 10. Well Campbell et al. No. 2 step test, s $/ Q$ versus $Q$. 


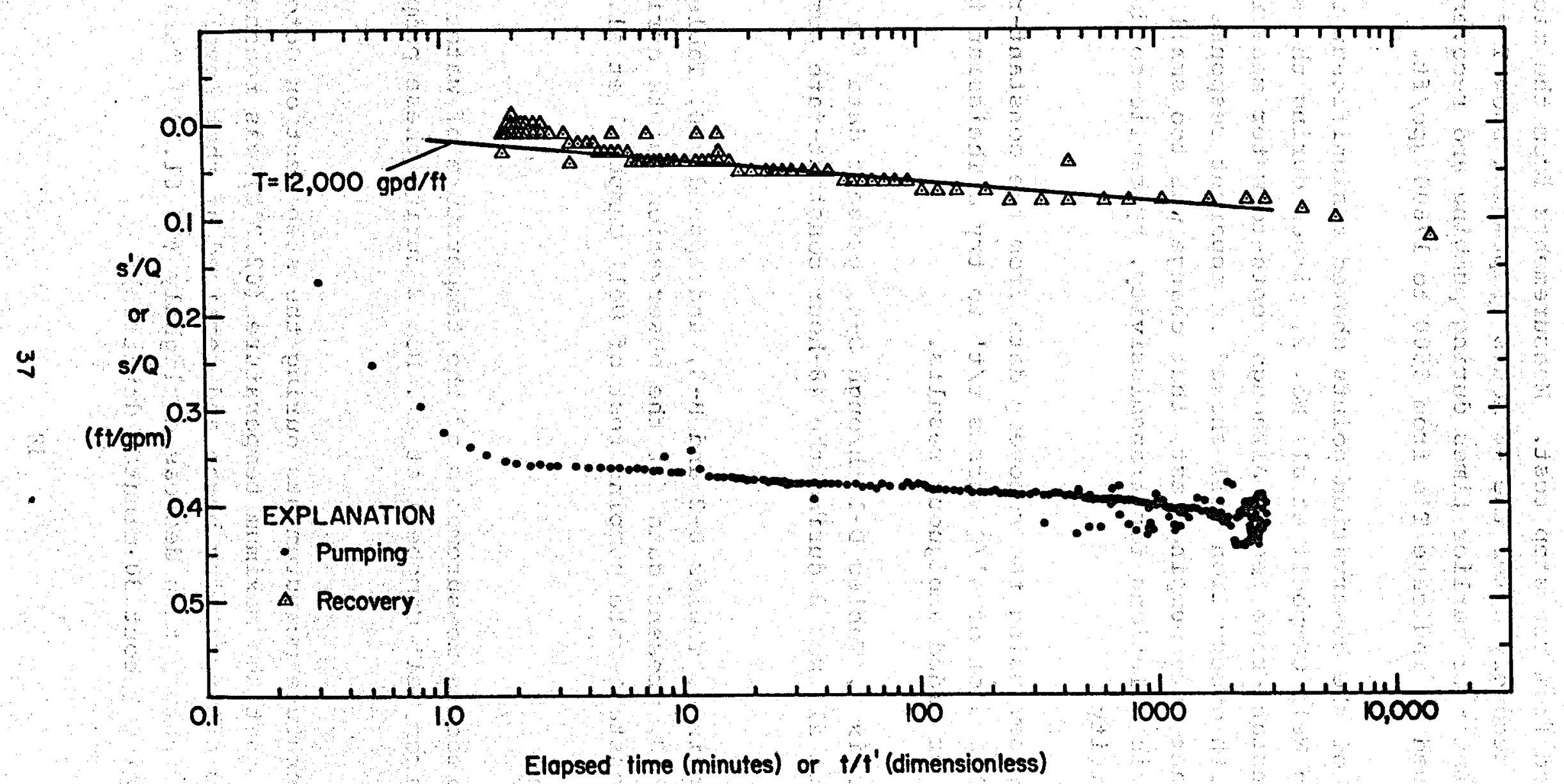

Figure II. Campbell et al. No. 2 constant-rate test, $s^{\prime} / Q$ or $s / Q$ versus elapsed time and $1 / t^{\prime}$. 
as obtained from the step test. Measurements from the middle period of recovery after the 48 hours of pumping show $T=12000$ gpd/ft. Later or earlier times during pumping and recovery could be construed to indicate T's from 6600 to $17600 \mathrm{gpd} / \mathrm{ft}$.

None of the observation points showed a significant response to pumping Well Campbell et al. No. 2, either during the step test or the constant-rate test. Although depth-to-water measurements at the North observation well showed an apparent response during the constant-rate pumping test, that change was too small to give any analytic solutions for transmissivity, hydraulic conductivity, or storativity.

Likewise, using the recovery data from the constant-rate test in a log-log plot of $s^{\prime} / Q$ versus $t / t$ ' to try a Theissian type curve fit provided ambiguous results.

Appendix $D$, Tables $D-1$ through $D-4$, present data for well Campbell et al. No. 2 during the 48-hour constant-rate pumping test.

Appendix B, Tables B-2 and B-3, and Appendix D, Tables D-5 through $D-10$, present data for the observation points during the 48-hour constant-rate pumping test of Well Campbell et al. No. 2 .

Temperature

Table 2 presents measurements of the temperature of water discharging from Well Campbell et al. No. 2 during these pumping tests.

Temperature measurements during the step test on october 6 , 1981 show that the maximum temperature $\left(62.2^{\circ} \mathrm{C}\right)$ was reached about 75 minutes after pumping began and remained at that level for about 45 minutes, then decreased slightly (to $61.7^{\circ} \mathrm{C}$ ) during the later pumping (about 30 minutes duration). 
TABLE 2. TEMPERATURE OF WATER DISCHARGING FROM

WELL CAMPBELL ET AL. NO 2 DURING

PUMPING TESTS, OCTOBER 1981.

\begin{tabular}{|c|c|c|c|c|c|}
\hline $\begin{array}{l}\text { Date } \\
\text { October } 1981\end{array}$ & $\frac{\text { Hour }}{\text { Hour }}$ & $\begin{array}{c}\text { Temperature } \\
\left({ }^{\circ} \mathrm{C}\right)^{2}\end{array}$ & $\begin{array}{c}\text { Date } \\
\text { October } 1981 \\
\end{array}$ & Hour & $\begin{array}{l}\text { Temperature } \\
\left({ }^{\circ} \mathrm{C}\right)^{\mathrm{a}}\end{array}$ \\
\hline 6 & 1426 & 60.0 & 7 & 1438 & 60.0 \\
\hline$\therefore \quad \therefore$ & $\begin{array}{l}1429 \\
\end{array}$ & 60.0 & H. IO & 1440 & 61.1 \\
\hline & 1435 & 60.6 & 10 & 1446 & 60.8 \\
\hline & 1437 & 61.1 & $\because \quad$ & 1451 & 61.1 \\
\hline & 1439 & 61.1 & $\therefore: 1$ & 1500 & 61.7 \\
\hline & 1443 & 61.1 & 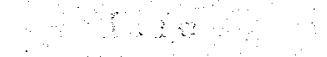 & 1510 & $61 \cdot 7$ \\
\hline & 1449 & 61.1 & $\theta+\theta$ & 1540 & 61.9 \\
\hline & 1452 & 61.1 & $\therefore \ldots$ & 1550 & 61.7 \\
\hline & 1459 & 61.1 & $\because 5$ & 1600 & 61.9 \\
\hline & 1508 & 61.7 & $5 \cdot 5$ & 1630 & 61.7 \\
\hline & 1521 & 61.7 & $s \cdot c$ & 1650 & 61.7 \\
\hline & 1530 & 62.2 & $3+3$ & 1710 & 61.7 \\
\hline & 1535 & 62.2 & 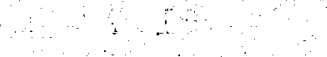 & 1730 & 61.7 \\
\hline & 1547.5 & 62.2 & $\therefore \theta$ & 1750 & 61.7 \\
\hline & 1553 & 62.2 & 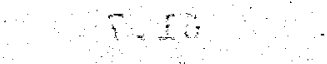 & 1810 & 61.7 \\
\hline & 1602 & 62.2 & $x+3$ & 1830 & 61.7 \\
\hline & 1607 & 62.2 & \& & 1850 & 61.7 \\
\hline & 1614.5 & 62.2 & I. & 1915 & 61.7 \\
\hline & 1617.5 & 61.7 & 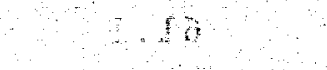 & 1930 & 61.7 \\
\hline & 1630 & 61.7 & 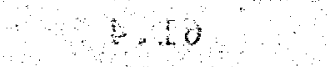 & 1950 & 61.7 \\
\hline & 1640 & 61.7 & & 2010 & 61.7 \\
\hline 7 & $\begin{array}{l}1432 \\
1435\end{array}$ & $\begin{array}{l}60.0 \\
60.6\end{array}$ & 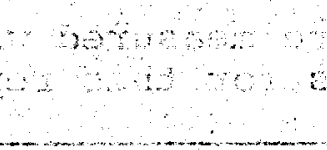 & $\begin{array}{l}2030 \\
2355\end{array}$ & $\begin{array}{r}61.7 \\
60.0\end{array}$ \\
\hline
\end{tabular}


TABLE 2. (continued)

\begin{tabular}{|c|c|c|c|c|c|}
\hline$\frac{\text { Date }}{\text { October } 1981}$ & Hour & $\begin{array}{c}\text { Temperature } \\
\left({ }^{\circ} \mathrm{C}\right)^{-a}\end{array}$ & $\begin{array}{c}\text { Date } \\
\text { October } 1981\end{array}$ & Hour & $\begin{array}{c}\text { Temperature } \\
\left({ }^{\circ} \mathrm{C}\right)^{\circ}\end{array}$ \\
\hline 8 & 0143 & 60.0 & 9 & 1133 & 61.4 \\
\hline 4 & 0603 & 61.1 & $a$ & 1407 & 62.2 \\
\hline & 0634 & 61.1 & 8 & 1423 & 62.2 \\
\hline$t$. & 0706 & 61.1 & 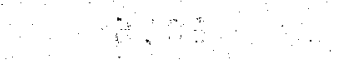 & & \\
\hline 3 & 0734 & 61.1 & & 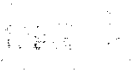 & \\
\hline & 0744 & 61.1 & $1<8$ & . & \\
\hline 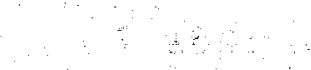 & 0804 & 61.1 & & 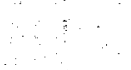 & \\
\hline & 0840 & 61.4 & $\therefore$ & ? & \\
\hline & 0920 & 61.1 & $:$ & & \\
\hline & 1020 & 61.7 & $\therefore$ & & \\
\hline 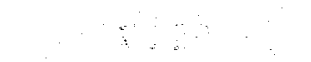 & 1120 & 61.7 & 3 & 48 & \\
\hline & 1220 & 61.9 & $\therefore$ & ? ? & \\
\hline$\ldots$ & 1320 & 62.2 & : & & \\
\hline$\therefore$ & 1720 & 61.7 & & is & \\
\hline & 2020 & 61.7 & & & \\
\hline & 2140 & 61.7 & & 3 & \\
\hline 9 & 0200 & 61.1 & & & \\
\hline & 0430 & 61.1 & $\ldots$ & 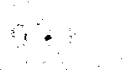 & \\
\hline & 0630 & 61.1 & & 50 & \\
\hline & 0830 & 61.1 & $\ldots$ & 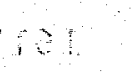 & \\
\hline 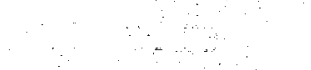 & 1005 & 61.4 & $i d$ & 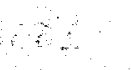 & \\
\hline
\end{tabular}

a. Temperatures were measured with a Fahrenheit thermometer and converted to Celsius for this report. 
During the constant-rate test, water temperature appears to show diurnal variation, with lowest temperatures reached between about 2100 and about 0900 each night. Maximums were reached between about 1300 and 1600 each day. These temperatures may document actual changes in the water temperature, or may reflect the combined effects of measurement in an un-insulated pipe and variation in worker's perception of the time required for the thermometer to equilibrate to the water temperature.

Comparison of measured water temperatures with the temperature log in Appendix $A$ shows that the discharging water commonly exceeded the bottom-hole temperature recorded during logging in spite of the fact that the measured total depth before these pumping tests was 15 feet less than the total depth measured during the temperature log:

D.A. Campbell reported that during the 10 minutes of pumping after the pump was installed (1730 to 1740 on October 5,1981$)$, the first water discharged at a temperature of $58.9^{\circ} \mathrm{C}\left(138^{\circ} \mathrm{F}\right)$. The first recorded temperature in each test was $60.0^{\circ} \mathrm{C}(140 ! \mathrm{F})$. Thus, the maximum variation in recorded water temperature is $2.2^{\circ} \mathrm{C}$ i the maximum variation in observed water temperature is $3.3^{\circ} \mathrm{C}$ for Well Campbell et al. No. 2 .

Temperature changes should cause the column of water in a well to expand or contract. From (a) the volume of water in well Campbell et al. No. 2 below the initial water level and (b) the relative volumes of water at $58.9^{\circ} \mathrm{C}$ and at $62.2^{\circ} \mathrm{C}$ (derived from Reference (4), expansion and contraction could cause a maximum change in water level of: 0.31 feet. Such a water-1evel change could appear as a decrease in depth to water when the temperature of water in the well increased (as during initial pumping), or as an increase in the depth to water when the temperature of water in the well decreased (as during late recovery). under ideal conditions, such an apparent change in depth to water could be measured during pumping tests. As mentioned elsewhere, several prob- 
lems combined to effectively reduce the accuracy of depth-to-water measurements in well Campbell et al. No. 2 during these tests and any changes caused by increase or decrease of water volume due to temperature variation cannot be separated from these other effects.

\section{DISCUSSION}

The text that follows addresses four questions:

1. Why didn't the observation wells respond more during pumping and why didn't the flow of the springs diminish?

2. What is the instantaneous optimum yield of this well and what are its first-year and forty-year yields?

3. What changes in head would occur if the well were to be pumped to its forty-year yield capacity?

4. How much would the flow of the springs change if the well were to be pumped to its forty-year yield capacity?

We could discuss the relationship of the well to the groundwater flow system and the consequent discharge-drawdown relationships in terms of many conceptual models. Figure 12 illustrates cross-sections of the four conceptual models that we will consider here.

Three of these models are as follows:

1. The well fully penetrates a horizontal layer of saturated homogeneous, isotropic, water-yielding rocks of uniform thickness in which all heads are initially identical (Theissian condition) (Figure 12a); 

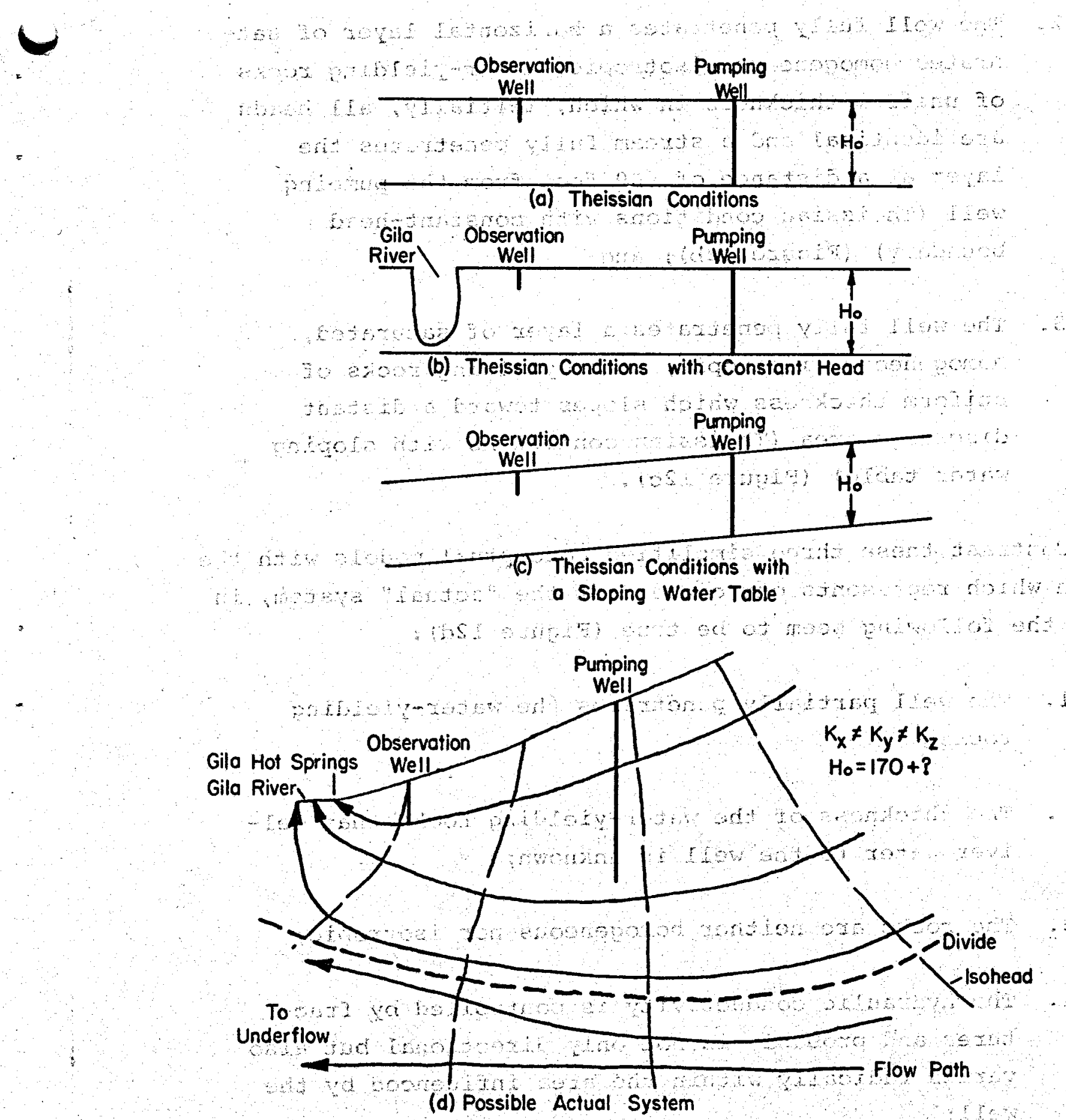

Figure 12. Profiles of the ground water flow system showing the relation of the pumping well, observation wells, and the Gila River or Gila Hot springs before pumping begins according to selected conceptual models. 
2. The well fully penetrates a horizontal layer of saturated homogeneous, isotropic, water-yielding rocks of uniform thickness in which, initially, all heads are identical and a stream fully penetrates the layer at a distance of 600 feet from the pumping well (Theissian conditions with constant-head boundary) (Figure 12b); and

3. The well fully penetrates a layer of saturated, homogeneous, isotropic, water-yielding rocks of uniform thickness which slopes toward a distant discharge area (Theissian conditions with sloping water table) (Figure 12c).

Contrast these three simplified conceptual models with the fourth which represents our concept of the "actual" system, in which the following seem to be true (Figure 12d):

1. The well partially penetrates the water-yielding rocks;

2. The thickness of the water-yielding rocks that deliver water to the well is unknown;

3. The rocks are neither homogeneous nor isotropic;

4. The hydraulic conductivity is controlled by fractures and probably is not only directional but also varies radically within the area influenced by the wel1;

5. The river penetrates the water yielding rocks only a few feet, but is a point of regional ground-water discharge; and

6. The head varies not only with the slope of the water table, but also with depth in the saturated rock. 


\section{1}

Our model of an "actual" system is itself incomplete because: (a) The hydraulic conductivity varies with water temperature; so even if the intrinsic permeability of the rocks were isotropic, the hydraulic conductivity could vary by a factor of 2 or 3 . (b) The role of faults as hydraulic boundaries has been ignored. The faults not only increase the number of fractures locally, but also cause rocks with different fracture densities to abut. (c) The reason for the springs existence (which we don't know) has been ignored. (d) The reason the springs discharge hot water has been ignored.

Figure 13, a through d, illustrates the head distribution around the pumping well for each conceptual model. At best we can use conceptual-models $1-3$ to make crude estimates of the parameters and of the yield of the well. To use the "actual" model would require a numerical simulation (computer model) of the three dimensional system and we lack sufficient data for this exercise. However, if we assume that the water levels observed in the wells near the Gila Hot springs represent an "averaging" of head (which varies with depth, as discussed in Appendix F) and if we assume that models $1-3$ provide estimates of the "verticallyaveraged" head obtained from model 4 , then models $1-3$ can be used with discretion to estimate the optimum and first-year yield of Well campbell et al. No. 2 and to estimate the impact of that discharge on water levels around the well and on the flow of the springs.

\section{observation Wells and Springs}

The South well has only four feet of casing. However, water appears to flow from the well and discharge continually into fractures that are tapped by a collection pipe. During the pumping test the water level did not change. We believe the discharge diminished about ten percent, but we do not have sufficient measurements to support our observations. 

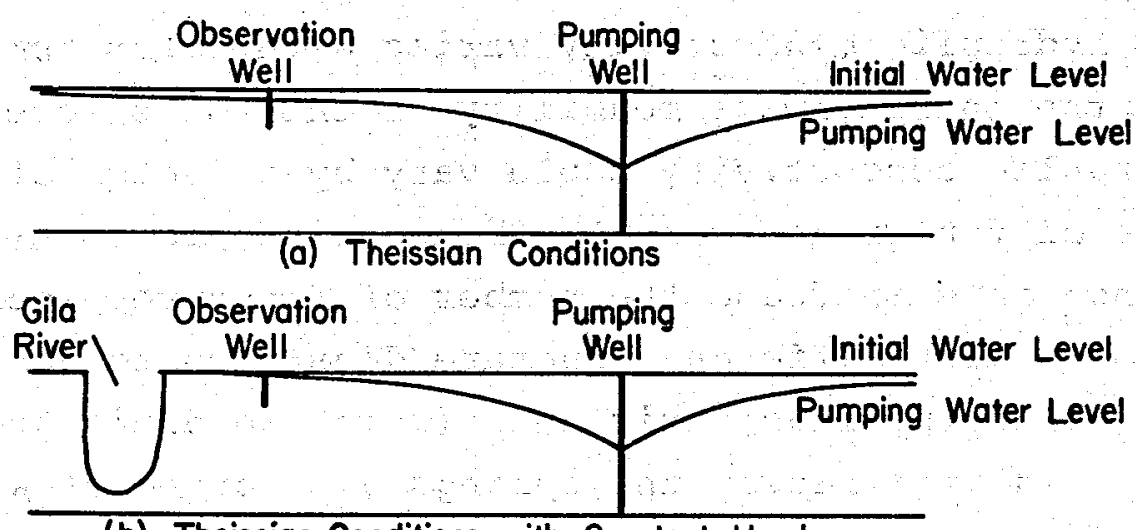

(b) Theissian Conditions with Constant Head

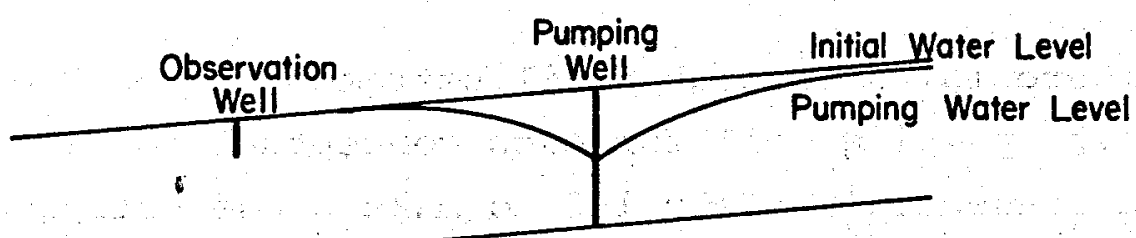

(c) Theissian - Conditions with

a Sloping Water Table

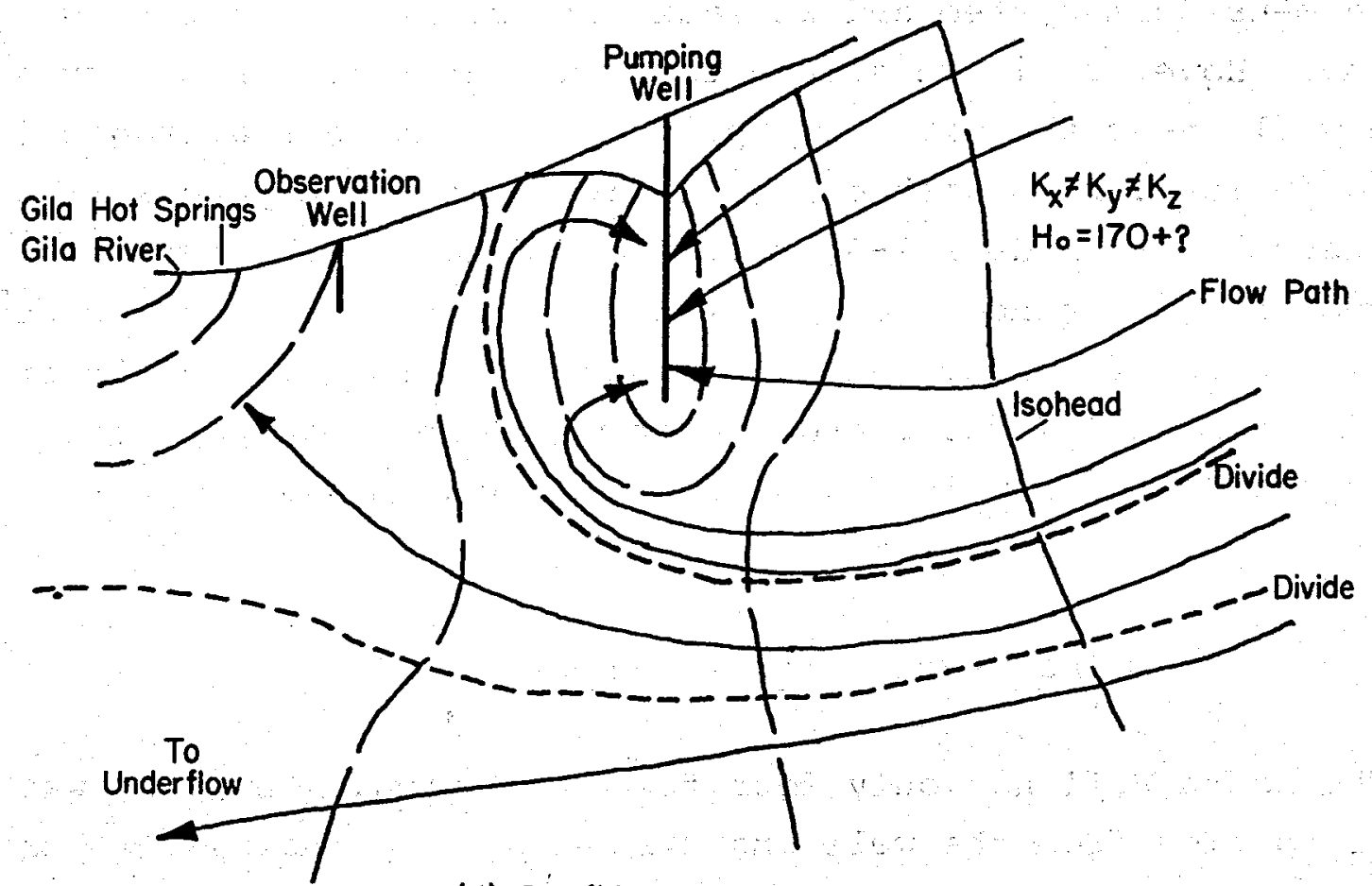

(d) Possible Actual System

Figure 13. Profiles of the ground water flow system showing the relation of the pumping well, observation well, and the Gila River or Gila Hot springs during the pumping period according to selected conceptual models. 
The measured depth to water in the North Well suggests that the water-level change due to pumping, Well Campbell et al. No. 2 might be as large as 0.2 foot.

The flume measurements, which are accurate to about one gallon per minute, showed no change in the flow of the two springs we monitored.

Four explanations can be called upon to explain these observations:

1. The rocks have a large specific yield,

2. Part of the water discharged derived from sources other than storage in the water-yielding rocks,

3.: The anisotropism of the system, and

4. The short-term effects of partial penetration of the pumping well and observation wells.

Specific Yield

If we assume Theissian conditions and determine the values of $S$ for which $s \leq 0.2$ in the observation well because Well Campbell et al. No. 2 - 500 feet away - pumped 50 gpm for 2 days, we see that $S$ must be 0.035 or larger

If we assume Theissian conditions with a constant head boundary and determine the value of $S$ for which the effect of pumping Well Campbell et al. No. 2 at $50 \mathrm{gpm}$ for 2 days would be to reduce the flow of the springs by less than 10 percent at the end of two days, we see that $S$ must be larger than 0.05 . This leads to two conclusions : the row

1. Values of $S$ of this magnitude suggest that $S=S_{Y}$ 
and that the water derived from porosity storage rather than elastic storage; and

2. Setting $S=0.05$ will produce better estimates of discharge and drawdown (under Theissian conditions) than would be produced if $S$ were assigned a smaller value.

\section{Water not from Storage}

Water not derived from storage could include (a) water from a constant-head source (conceptuai model 2), or (b) water moving through the rock toward the river is intercepted by the well (conceptual model 3 ).

Assuming a constant-head boundary at the river the discharge rate attributable to the constant-head source at the end of pumping $50 \mathrm{gpm}$ for forty years would be about $50 \mathrm{gpm}$. That is, after forty years of continuous pumping, the constant-head conceptual model calls for all the water to come from the constanthead source. We could interpret this to mean that the groundwater discharge to the river would be diminished by the amount of discharge of the well.

The sloping water-table model (Figure 13c) assumes that water is moving through the rocks at a rate determined by the slope of the water table and the transmissivity of the rocks, that is

$Q \times 1440=T I L$

where

$Q$ is the volume of water in gpm that passes through a vertical section of rock $L$ feet wide under the hydraulic gradient $I$. 
So if we assume that the hydraulic gradient in the vicinity of Well Campbell et al. No. 2 is equal to $26 / 5280$ (or the gradient of the Gila River at the springs), then

$\mathrm{I}=(50 \times 1440 \times 5280) /(13000 \times 26)=1125 \mathrm{feet}$

However if we base the gradient on the water-level altitude differences between Well Campbell et al. No. 2 and the North Well, the gradient would be about 25 feet in 500 feet or $0.05 \mathrm{ft} / \mathrm{ft}$. So

$I=(50 \times 1440) /(13000 \times 0.05)=111$ feet

That is, (a) the total volume of water discharge from the well is water that would have discharged eventually to either the springs or to the Gila River some place down gradient from the well and (b) in the vicinity of the well the water moves through a strip of rocks that is either 111 feet or 1125 feet wide. In either case some water would actually have had to come from storage to change the flow system in the vicinity of the well and the waterlevel change in the observation well would be less accordingly. The flow of the springs or of the river would diminish (eventually) by the amount of water intercepted by the well, but would not necessarily show a measureable decrease in the flow of the springs during the test period.

Anisotropism

Because the rocks are fractured, the possibility exists that the dominant fractures parallel the river so that the impact of pumping would be felt much later at the observation wells than we would expect if the rocks were isotropic.

Partial Penetration

In complex ground-water flow systems, pumping a deep well 
may have little influence on shallow wells until pumping has gone on for many days. The predicted "vertically-averaged" head change may be arelatively large number; whereas the head change observed in a shallow well may be negligible. Because the head change at depth may be substantial the predicted "vertically-averaged" head change may actually occur at only one point along the axis of the observation well extended downward.

\section{Postscript}

We can account for the lack of response in the observation wells and the undiminished flow of the springs when Well

Campbell et al. No. 2 was pumped in several other ways than those cited above. Some preceptions of the relation of the well to the flow system automatically dictate that the flow of the springs will diminish -- some more than others.

Still other preceptions can be entertained in which the discharge of the springs would be unaffected by the discharge of the well.

We argue that we are more conservative, if we predict more effect on the springs than will actually occur, because the effects of overestimating are correctible -- those of underestimating are not.

\section{Optimum Instantaneous Discharge and "First-year" Yield}

Appendix $G$ presents the formulation for calculating the optimum yield of a well.

Based on test results and our knowledge of Well Campbell et al. No. $2\left(T=13000 \mathrm{gpd} / \mathrm{ft}, C=0.0047 \mathrm{ft} / \mathrm{gpm}^{2}, a=0.0074\right.$, and $S^{\prime}=0.05$ ) we determined the optimum discharge at the end of the first year of pumping for this well is $50 \mathrm{gpm}$ with 20 feet drawdown. Based on the same values for parameters, the optimum 
discharge at the end of forty years would be 49 gpm with 22 feet of drawdown. The sustained yield for the first year and for forty years would be 91 and 3624 acre-feet respectively $(90.6$ $a c-f t /(y r)$.

\section{anding}

$6 \cos$ moting

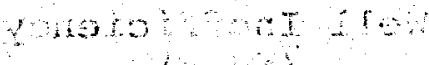

If the well were to be enlarged and deepened, so that $r=0.5$ and $\mathrm{H}_{\theta}=340$ feet and-if we were able to improve the well efficiency factor to $0.00047 \mathrm{ft} / \mathrm{gpm}^{2}$ and $a$ to 0.01 , then we would have the following:

\begin{tabular}{|c|c|c|c|c|}
\hline & optimum & $\therefore$ & & Leld \\
\hline $\begin{array}{c}\text { Elapsed } \\
\text { Time (days) } \\
\end{array}$ & $\begin{array}{c}\text { Instantaneous } \\
\text { Discharge } \\
\end{array}$ & Drawdown & $\begin{array}{r}\text { Total } \\
(a c-f t) \\
\end{array}$ & $\begin{array}{l}\text { Average } \\
(\mathrm{ac}-\mathrm{ft} / \mathrm{yr}) \\
\end{array}$ \\
\hline 1 & $\therefore 141$ & 25 & 0.6 & 226 \\
\hline 365 & $\therefore 138$ & 320 & 223 & 223 \\
\hline 14600 ( 40 yrs) & 137 & 36 & 8846 & 221 \\
\hline
\end{tabular}

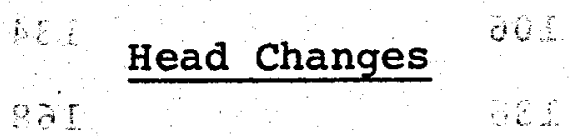

The discussion of head changes of necessity falls into two parts:

1. A discussion of the changes that we can expect in the pumping well at various pumping rates, and

2. A discussion of the change that we can expect in the vicinity of the pumping well.

In Pumping Well

Because Well Campbell et al. No. 2 is relatively inefficient, the water-level change we can expect will be much more than we would predict for an efficient well at the same site.

Tables 3 and 4 compare the total drawdown and drawdown due to well inefficiency in well Campbell et al. No. 2 at the end of 
TABLE 3. DRAWDOWN DUE TO WELL INEFFICIENCY AND TOTAL DRAWDOWN IN WELL CAMPBELL ET AL. NO 2 AT END OF ONE YEAR, BASED ON $T=13,900$ gpd/ft.

\begin{tabular}{ccc}
\hline $\begin{array}{c}\text { Discharge } \\
\text { Rate } \\
\text { (gpm) }\end{array}$ & $\begin{array}{c}\text { Drawdown due to } \\
\text { Well }\end{array}$ & $\begin{array}{c}\text { Total } \\
\text { (feet) }\end{array}$ \\
\hline 10 & 0.47 & $\begin{array}{c}\text { Drawdown } \\
\text { (feet) }\end{array}$ \\
\hline 20 & 1.88 & 2.35 \\
30 & 4.23 & 5.60 \\
40 & 7.52 & 9.81 \\
50 & 11.8 & 15.0 \\
75 & 26.4 & 21.1 \\
100 & 47.0 & 40.4 \\
125 & 73.4 & 65.6 \\
150 & 106 & 96.7 \\
170 & 136 & 134 \\
\hline
\end{tabular}


(

TABLE 4. DRAWDOWN DUE TO WELL INEFFICIENCY AND TOTAL DRAWDOWN EXPECTED IN WELL CAMPBELI ET AL. NO 2 BASED ON $\mathbf{T}=12,000 \mathrm{gpd} / \mathrm{ft}$.

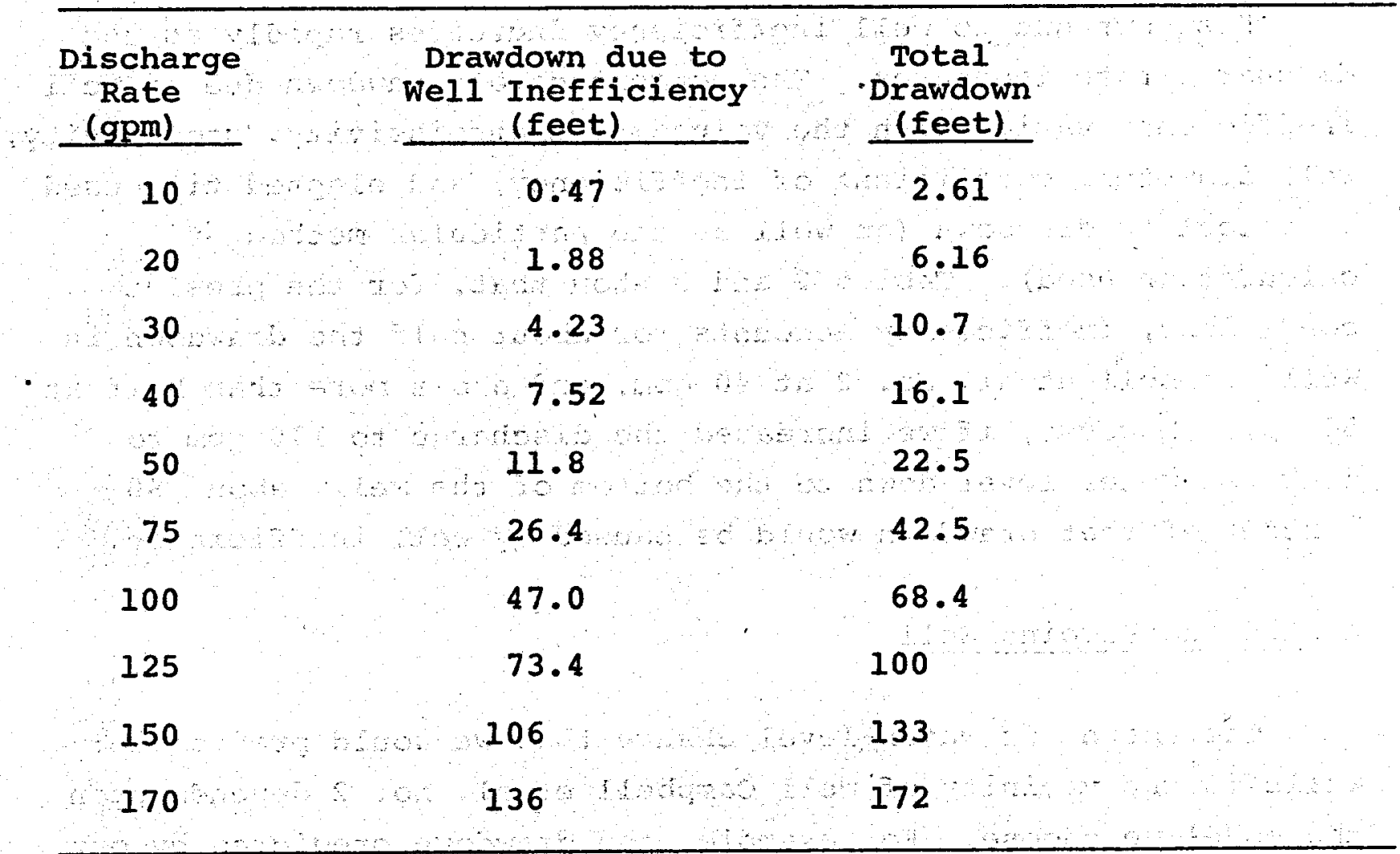


one year based on transmissivity values of $13,900 \mathrm{gpd} / \mathrm{ft}$ and 12,000 gpd/ft respectively.

Drawdown due to well inefficiency increases rapidly as the discharge rate increases. The percentage of drawdown due to well inefficiency varies with the values of transmissivity, storativity, well diameter, coefficient of inefficiency, and elapsed time used to calculate drawdown (as well as the particular method of calculation used). Tables 2 and 3 show that, for the present conditions, inefficiency accounts for about half the arawdown in Well Campbell et al. No. 2 at $40 \mathrm{gpm}$, and a bit more than half at $50 \mathrm{gpm}$. However, if we increased the discharge to $170 \mathrm{gpm}$ to draw the water level down to the bottom of the well, about 80 percent of that drawdown would be caused by well inefficiency.

Around the Pumping Well

The amount of water-level change that we would predict for wells in the vicinity of Well Campbell et al. No. 2 depends upon the model we choose. For example, the drawdown predicted by our three conceptual models for the North observation well due to pumping Well Campbell et al. No. 2 at $50 \mathrm{gpm}$ are:

\begin{tabular}{|c|c|c|}
\hline Mode1 & $\begin{array}{c}\text { Predicted } \\
\text { Water-level } \\
\text { Change (ft) }\end{array}$ & $\begin{array}{l}\text { Elapsed } \\
\text { Time }\end{array}$ \\
\hline Theissian conditions & 5.1 & 1000 years \\
\hline $\begin{array}{l}\text { 2. Theissian conditions with constant } \\
\text { head boundary }\end{array}$ & 0.2 & Equilibrium \\
\hline
\end{tabular}

3. Theissian conditions, sloping water table

River gradient

Well gradient
$4.4-4.5$

2. 4-2.6
Equilibrium

Equilibrium 
For long-term planning purposes the estimate of 2.4 to 2.6 feet of change at the North well is probably the most realistic. For short-term planning purposes the relative water-level change at the North Well could be taken as 50 to 75 percent of the equilibrium estimate (roughly 1 to 2 feet)

Changing the zpumping rate will alter the water-level change prediction in proportion to the change in pumping rates, That is, doubling the pumping rate will double the estimated water-level change.

\section{anopoweros}

\section{Impact on the springs}

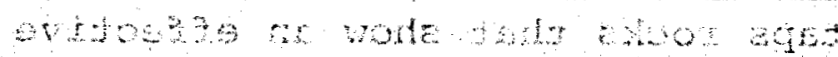

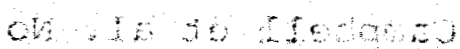

IThe estimated impact of pumping Well Campbell et al. No. 2 on the flow of the Gila Hot Springs also depends upon the conceptualization we choose. Some effect seems inevitable. The worst-case estimate is that pumping the well for a long period of time will reduce the flow of the springs by the amount pumped. Until we know more about the head distribution and the distribution of hydraulic conductivity of the rocks around the springs, the wisest course would be to use this worst-case assessment.

$\frac{\text { Maximum Temperature }}{20}$ ot of
The temperature log of Well Campbell set al. No. 2

(in Appendix A) does not show a uniform rate of temperature increase with depth. Therefore, the amount of temperature increase that can reasonably be expected to result from deepening well Campbell et al. No. 2 ls a moot point, Based on the entire logged interval, deepening well Campbell et al. No. 2 to 420 feet should increase the temperature at the total depth to $83^{\circ} \mathrm{C}\left(181^{\circ} \mathrm{F}\right)$; based on the temperature $10 \mathrm{~g}$ from 165.6 feet to 265.0 feet, the temperature at 420 feet should be $70^{\circ} \mathrm{C}\left(158^{\circ} \mathrm{F}\right)$; and based on the temperature log from 212.2 feet to 265.0 feet, the temperature at 420 feet should be $66^{\circ} \mathrm{C}\left(151^{\circ} \mathrm{F}\right)$ 
Figure 13 (d) shows possible flow paths for water entering Well Campbell et al. No. 2. Figures 3 and 4 show possible isotherms based on available temperature data. These diagrams show that the small increase in temperature experienced during these tests probably results from the manner in which the well intercepts water more laterally than vertically. Thus, deepening the well should have a greater impact on the temperature of water discharged than would enlarging or developing the well to increase the discharge rate.

\section{CONCLUSIONS}

Well Campbell et al. No. 2 taps rocks that show an effective transmissivity in the range of 12,000 to $14,000 \mathrm{gpd} / \mathrm{ft}$, which indicates a hydraulic conductivity in the range of 70 to 80 gpd $/ \mathrm{ft}^{2}$.

In its present condition, Well Campbell et al. No. 2 should be pumped at a discharge rate of $50 \mathrm{gpm}$ or less to avoid wasting energy fighting well inefficiency.

The relatively small values of drawdown compared to the depth of water available in this well indicates that the optimum yield is controlled by factors related to well configuration and efficiency more than by the water-yielding properties of the rocks.

Enlarging Well Campbell et al. No. 2, cleaning or developing the well to increase its efficiency, or deepening it should significantly increase the optimum discharge rate.

Pumping Well Campbell et al. No 2 for forty years at $50 \mathrm{gpm}$ will have a trivial effect on water levels in wells a few hundred feet distant. It will diminish the flow of the springs, and for planning purposes the flow of the springs plus the discharge of the well should be considered a constant. 
REFERENCES

1. J.C. Ratte, D.L. Gaskill, "Relative Ages of the Gila Cliff Dwellings and Bursum Calderas, Mogollon Mountains, New Mexico," Geological Society of America Ab'stracts with programs, 5,6 ; $1973, \mathrm{p} .505$.

2. J.C. Ratte, D.I.Gaskil1, Reconnaissance Geologic Map of the Gila Wilderness Study Area, Southwestern New Mexico, United States Geological Survey, Misc. Inv. Series Map I-886, 1975, 2 sheets.

3. J.C. Ratte, D.I. Gaskil1, G.P.Eaton, ID.L.Peterson, R.B. Stotelmeyer, H.C. Meeves, Mineral Resources of the Gila Primitive Area and Gila Wilderness, New Mexico, United States Geological survey, Bulletin $1451,1979$.

4. Michael Bikerman, "New K-Ar Ages on Volcanic Rocks from Catron and Grant Counties, N.M.", Isochron/West, 3, 1972, pp.9-12.

5. W.E. Elston, P.E. Damon, P.J. Coney, R.C. Rhodes, E.I. Smith, Michael Bikerman, "Tertiary Volcanic Rocks, Mogollon-Datil Province, New Mexico, and surrounding Region - K-Ar Dates, Patterns of Eruption, and Periods of Mineralization," Geological Society of America Bulletin, 84, 1973, pp. 2259-2274.

6. P.E. Damon, Correlation and Chronology of Ore Deposits and Volcanic Rocks, U.S. Atomic Energy Commission Pub. C00-689130 (Arizona University Annual Progress Report), 1970.

7. W.E. Elston, "Terminology and Distribution of Ash Flows of the Mogollon-Silver City-Lordsburg Region, New Mexico," Geological Society of America Cordilleran Section, 64 th Annual Meeting, Tucson, Arizona, 1968, Arizona Geological Society, Southern Arizona Guidebook 3, pp. 231-240. 
8. W.K. Summers, Catalog of Thermal Waters in New Mexico, New Mexico Bureau of Mines and Mineral Resources, Hyarologic Report 4, 1976.

9. W.K. Summers, R.M. Colpitts, Jra, Preliminary Appraisal of the Hydrothermal-Resource Potential of the Gila Hot Springs Area, Grant and Catron Counties, New Mexico, W.K. Summers and Associates, Inc. Report to D.A. "Doc" and Ida Campbell, August 20,1980 .

10. F.D. Trauger, Water Resources and General Geology of Grant County, New Mexico, New Mexico Bureau of Mines and Mineral Resources, Hydrologic Report 2, 1972.

11. C.E. Jacob, "Flow of Ground Water," Chapter 5 in H. Rouse (editor), Engineering Hydraulics, New York, New York: John Wiley and Sons, Inc., 1950, pp. 321-386.

12. Y.K. Birsoy and W.K. Summers, "Determination of Aquifer Parameters from step Tests and Intermittent Pumping Data," Ground water, 18, 2, 1980, pp. 137-146.

13. J.R. Harrill, Determining Transmissivity from Water-Level Recovery of a Step-Drawdown Test, United States Geological Survey Professional Paper 700-C, 1971, pp. C212-C213.

14. C.D. Hodgman; R.C. Weast, S.M. Selby (editors), Handbook of Chemistry and Physics, 42 nd edition, cleveland, ohio: The Chemical Rubber Publishing Co.. 1960, p. 2143. 


$$
\text { A Almbets }
$$

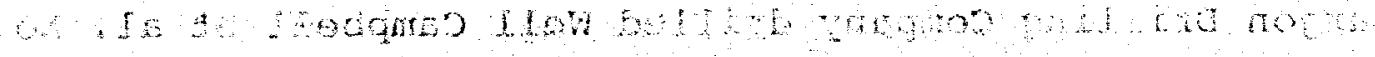

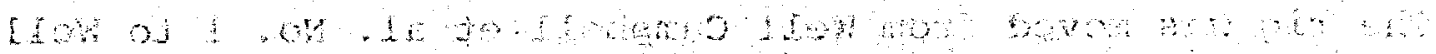

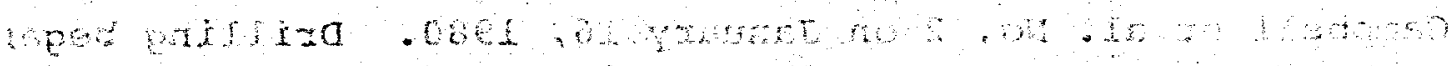

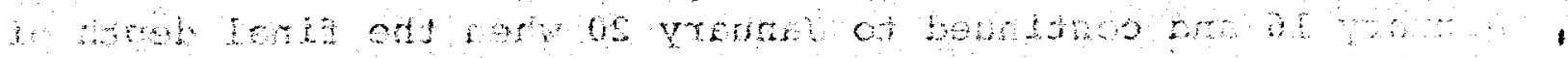

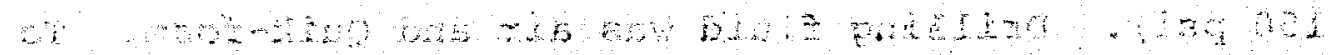

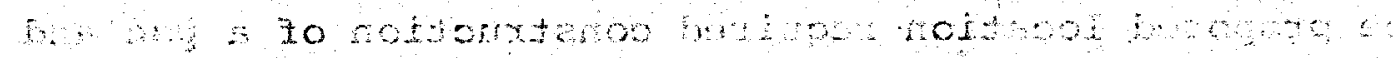

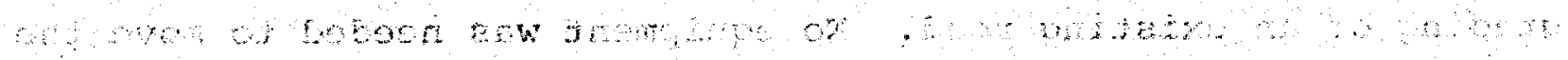

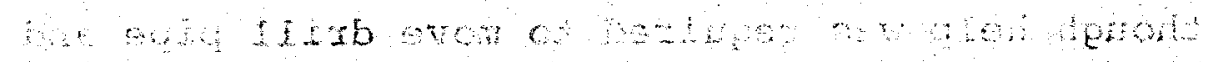

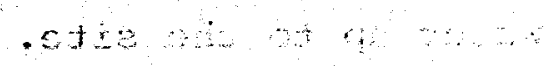

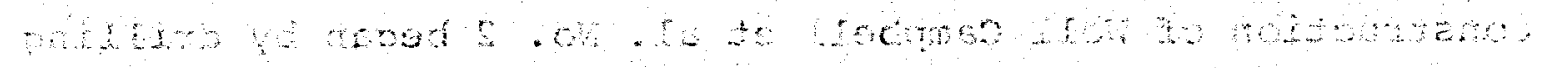

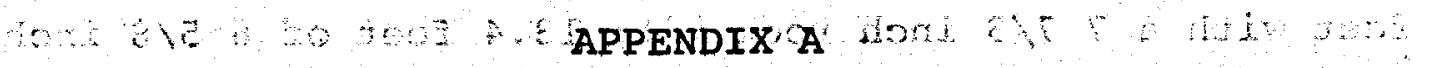

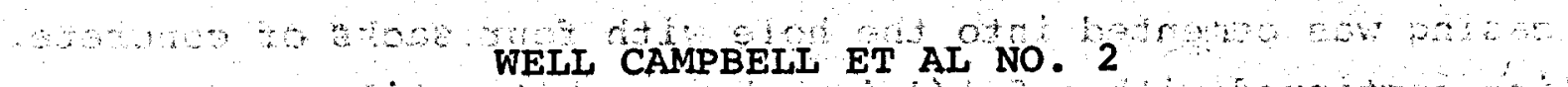
and bat

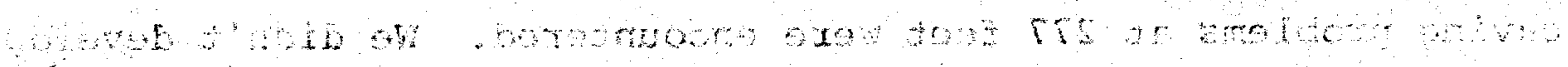

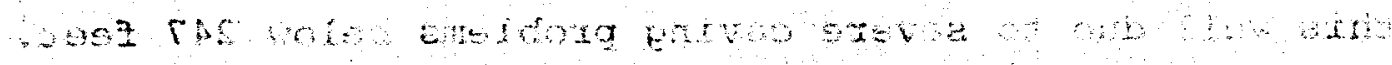




\section{APPENDIX A}

Well Campbell et al. No. 2

Larjon Drilling Company drilled Well Campbell et al. No. 2 . The rig was moved from Well Campbell et al. No. 1 to Well Campbell et al. No. 2 on January 16, 1980. Driliing began January 16 and continued to January 20 when the final depth of 277. feet was reached.

The arilling rig was a Franks KF-50 with a WBK compressor (500 cfm at $150 \mathrm{psi}$. Drilling fluid was air and Quik-foam. To move to the proposed location required construction of a pad and grading of an existing road. No equipment was needed to move the rig on location, though help was required to move drill pipe and water up to the site.

Construction of Well Campbell et al. No. 2 began by arilling to 13 feet with a $77 / 8$ inch rock bit: 13.4 feet of $65 / 8$ inch O.D. casing was cemented into the hole with four sacks of concrete. Drilling continued with a $51 / 4$ inch hammer bit until severe caving problems at 277 feet were encountered. We didn't develop this well due to severe caving problems below 247 feet. 
FIELD LOG: Well Campbell et al. No. 2 , (NEk, NWh, NEk, Sec. 5, T. $13 \mathrm{~S} ., \mathrm{R}_{\text {. } 13 \mathrm{~W} .)}$ Grant County, New Mexico

By: R.M. Colpitts, Jr., January 1980

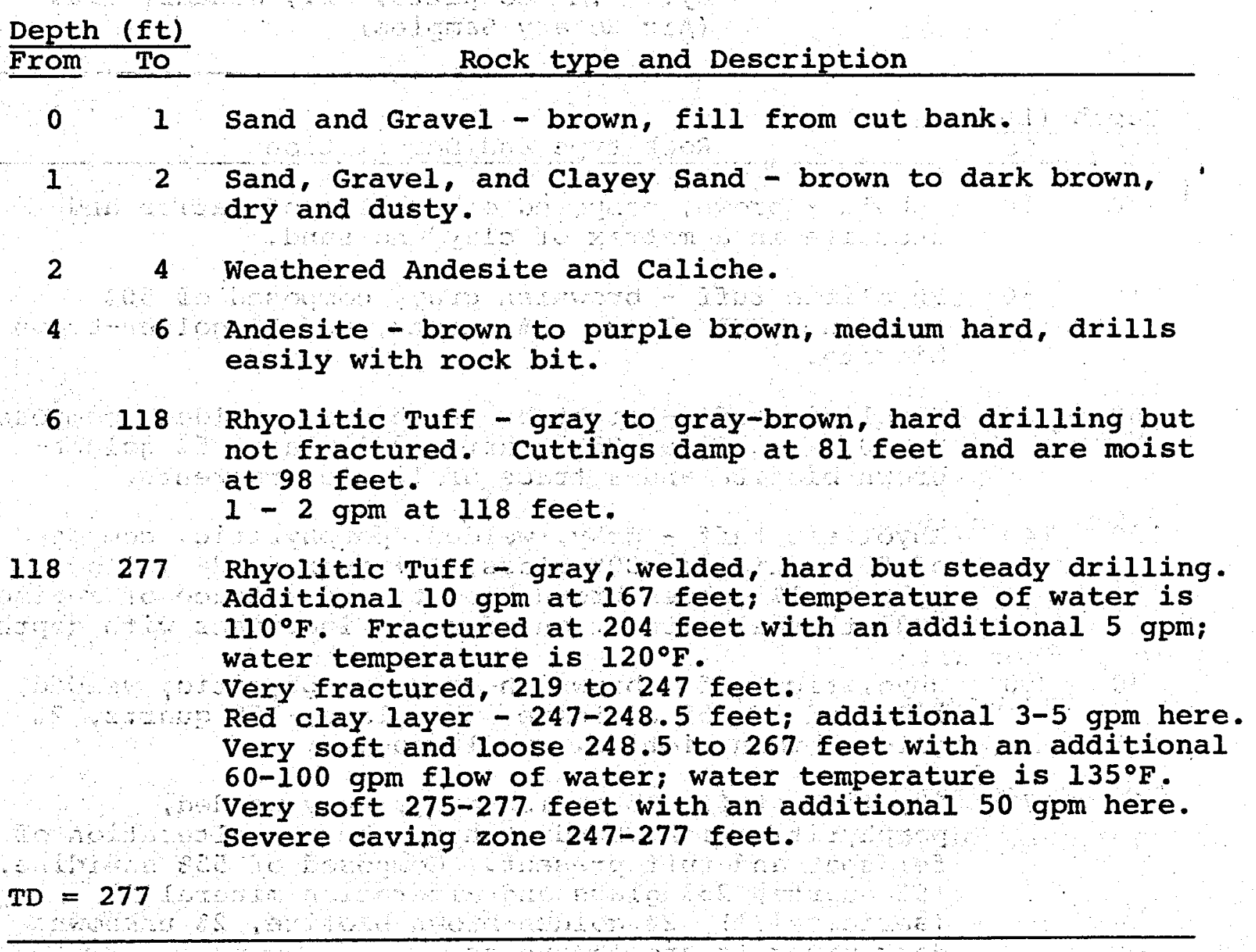


LITHOLOGIC DESCRIPTION

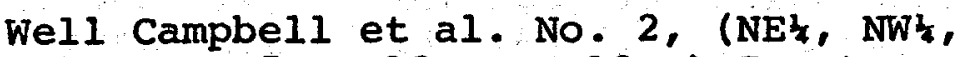
NE $\frac{1}{4}$, Sec. 5, T.13S., R.13W.) Grant County, New Mexico

By: R.M. Colpitts, Jr., January 1980

(Air Rotary Samples)

$\int_{0}^{\frac{\text { Depth }}{\text { From }}} \frac{(f t)}{\frac{\text { To }}{10}}$

Rock type and Description

Rubble - brown, composed of pebbles of latite and andesite in a matrix of clay and sand.

10 60 Rhyolitic tuff - brownish gray, composed of 508 sanidine, 338 glass, 158 quartz, and 28 golden-brown biotite.

$60 \quad 120$ Rhyolitic tuff - light brownish gray, welded, composed of 50 \% sanidine, 258 quartz, 208 glass, 58 goldenbrown biotite and a trace of lithic fragments.

$120 \quad 140$ Rhyolitic tuff - gray, welded, porphyritic, composed of 558 sanidine, 308 glass, 128 quartz, 28 yellow sphene, 18 golden-brown biotite and a trace of augite. Hydrothermal alteration of rocks increases with depth.

140250 Rhyolitic tuff - brownish-gray, porphyritic, welded, composed of 558 sanidine, 278 glass, 158 quartz, 28 golden-brown biotite, and 18 augite.

250277 Rhyolitic tuff - brownish-gray, very welded, porphyritic with abundant hydrothermal alteration of feldspar and tuff present. Composed of 558 sanidine, 158 quartz, 258 glass and alteration minerals (sericite[?]), 28 golden-brown biotite, 28 unknown dark minerals and 18 augite.

औ

$\mathrm{TD}=277$ 
TEMPERATURE. LOG: Well Campbell et al No. 2, NE4, NWt, NEk,

Sec. 5, R.13S., R.13W., Grant County, New Mexico By: D. Gambill and A. Kron (LASL) and R.M. Colpitts, Jr., January 30,1980

\begin{tabular}{|c|c|c|c|c|c|c|}
\hline $\begin{array}{c}\text { Depth } \\
\text { (ft) }\end{array}$ & ${ }^{\circ} \mathrm{C}$ & ${ }^{\circ} \mathrm{F}$ & & $\begin{array}{l}\text { Depth } \\
(\mathrm{ft}) \\
\end{array}$ & ${ }^{\circ} \mathrm{C}$ & ${ }^{\circ} \mathrm{F}$ \\
\hline 0 & -- & -- & & 170.8 & 56.0 & 132.8 \\
\hline 52.0 & 30.8 & 87.4 & & 175.9 & 56.8 & 134.2 \\
\hline 72.4 & 35.2 & 95.4 & & 181.1 & 57.4 & 135.3 \\
\hline 81.8 & 39.6 & 103.3 & & 186.3 & 57.7 & 135.9 \\
\hline 82.8 & 39.8 & 103.6 & & 191.5 & 58.2 & 136.8 \\
\hline 88.0 & 40.4 & 104.7 & & 196.6 & 58.5 & 137.3 \\
\hline 93.2 & 41.3 & 106.3 & & 201.8 & 58.8 & 137.8 \\
\hline 98.3 & 42.3 & 108.1 & & 207.0 & 59.1 & 138.4 \\
\hline 103.5 & 43.1 & 109.6 & & 212.2 & $59 \cdot 3$ & 138.7 \\
\hline 108.7 & 44.2 & $111 \cdot 6$ & & 217.3 & 59.5 & 139.1 \\
\hline 113.8 & 44.8 & 112.6 & & 222.5 & 59.7 & 139.5 \\
\hline 119.0 & 45.9 & 114.6 & & 227.7 & 59.9 & 139.8 \\
\hline 124.2 & 46.7 & 116.1 & a $\mathrm{xak} \mathrm{b}$ & 232.9 & 60.2 & 140.4 \\
\hline 129.4 & 47.8 & 118.0 & & 238.0 & 60.4 & 140.7 \\
\hline 134.5 & 48.9 & 120.0 & m nandon mas & 243.2 & 60.6 & 141.1 \\
\hline 139.7 & 50.0 & 122.0 & 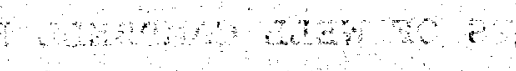 & $248 \cdot 4$ & 60.7 & $141 \cdot 3$ \\
\hline 144.9 & 51.1 & $124 \cdot 0$ & & 253.6 & 60.8 & 141.4 \\
\hline 150.1 & 52.2 & 126.0 & & 258.7 & 60.9 & 141.6 \\
\hline 155.2 & 53.2 & 127.8 & & 263.9 & 60.9 & 141.6 \\
\hline 160.4 & 54.3 & 129.7 & & 265.0 & 61.0 & 141.8 \\
\hline 165.6 & 55.1 & 131.2 & & $T D=265$ & & \\
\hline
\end{tabular}




\section{APPENDIX B}

DISCHARGE MEASUREMENTS OF

FLUMES DURING TESTS OF WELL CAMPBELL ET AL. NO. 2 
TABLE B-1, DISCHARGE MEASUREMENTS AT FLUME NO, 1, GIIA HOT SPRINGS, NEW MEXICO IN OCTOBER $1981,2, \mathrm{~W}$

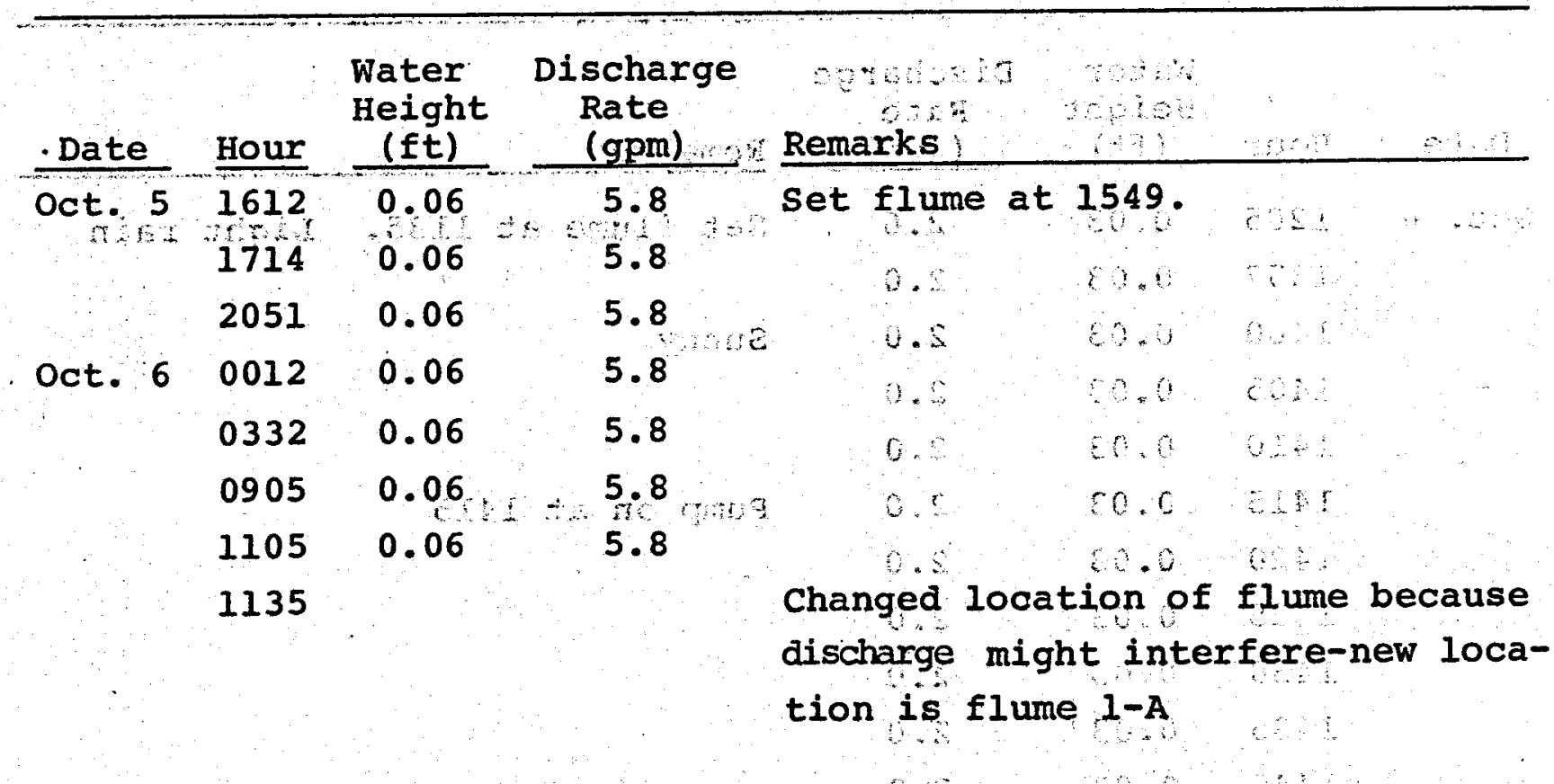

i.

6.6

1.s.

t.

0.5

0.5

a.:

o.

$-8$

4.5

an. 0

8.9

औ.

a.

9.

0,8

\section{0}

\section{0}

$8 \mathrm{~s}$

$\mathrm{cts}$

?

0,0

e.

0.5

th.

C.

a

Qn

0.2

\&a,

0,0

60

$\mathrm{s}$ 


\section{APPENDIX B}

TABLE B-2. DISCHARGE MEASUREMENTS AT FLUME NO, 1-A, GILA HOT SPRINGS, NEW MEXICO, IN OCTOBER 1981

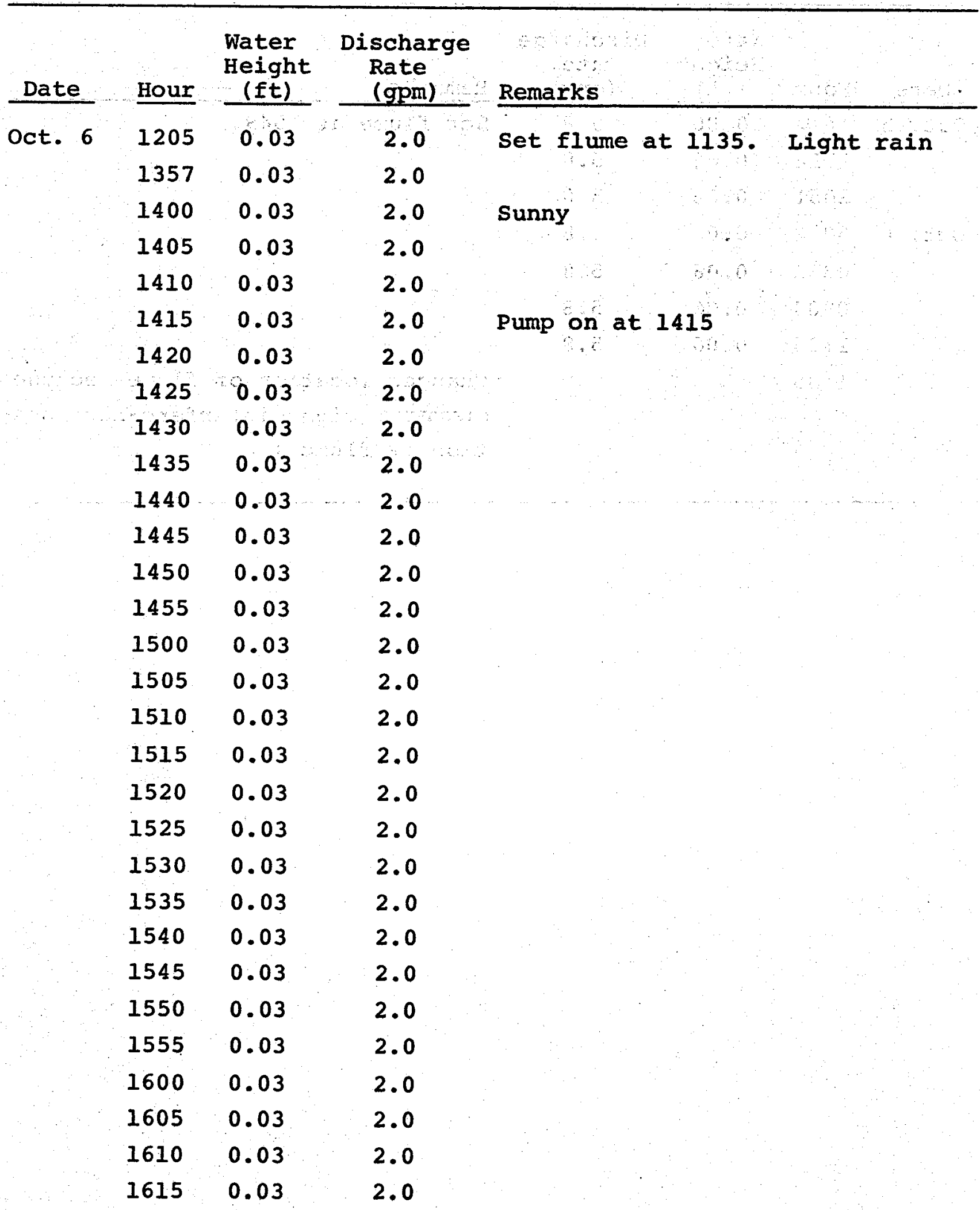




\section{TABLE B-2 (continued)}

\begin{tabular}{|c|c|c|c|c|c|c|c|}
\hline Date & Hour & $\begin{array}{l}\text { Water } \\
\text { Height } \\
\text { (ft) }\end{array}$ & $\begin{array}{c}\text { Discharge } \\
\text { Rate } \\
(\text { gpm })\end{array}$ & $\begin{array}{r}\text { Remarks } \\
\text { Remas }\end{array}$ & 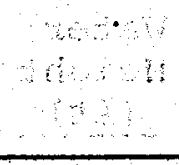 & & \\
\hline \multirow[t]{22}{*}{ oct 6} & 1620 & 0.03 & 2.0 & 6 & 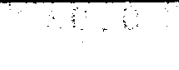 & 8 & \\
\hline & 1625 & 0.03 & 2.0 & 15 & $\therefore \quad ;$ & & \\
\hline & 1630 & 0.03 & 2.0 & 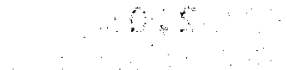 & $b$, & $\because 8$ & \\
\hline & 1635 & 0.03 & 2.0 & 0. & $2 \ldots$ & 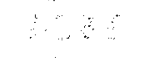 & \\
\hline & 1640 & 0.03 & 2.0 & $\therefore$ & $\therefore$. & $\cdots$ & \\
\hline & 1645 & 0.03 & 2.0 & $\ldots$ & $8+2$ & 8 & \\
\hline & 1650 & 0.03 & 2.0 & 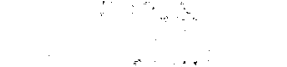 & $\therefore$ & $\therefore$ & \\
\hline & 1655 & 0.03 & 2.0 & 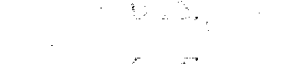 & $\theta 0$ & & \\
\hline & 1700 & 0.03 & 2.0 & 5 & $8 \mathrm{c}$ & 3 & \\
\hline & 1705 & 0.03 & 2.0 & $\therefore$ & $\therefore \quad \therefore$ & & \\
\hline & 1710 & 0.03 & 2.0 & 0. & $\therefore$ & & \\
\hline & 1715 & 0.03 & 2.0 & $3+2$ & 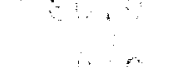 & & \\
\hline & 1725 & 0.03 & 2.0 & & 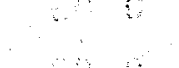 & & \\
\hline & 1735 & 0.03 & 2.0 & $2 \ldots$ & $\therefore \quad \cdots$ & & \\
\hline & 1745 & 0.03 & 2.0 & $\because$ & 3 & & \\
\hline & 1800 & 0.03 & 2.0 & $\therefore=$ & $\therefore$ & & \\
\hline & 1832 & 0.03 & 2.0 & 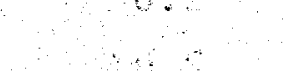 & 4 & $\therefore$ & \\
\hline & 1900 & 0.03 & 2.0 & & $\cdots$ & $\cdots$ & \\
\hline & 1957 & 0.03 & 2.0 & 4 & \& & $0 \%$ & \\
\hline & 2050 & 0.03 & 2.0 & 8 & 6 & 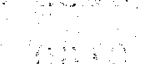 & \\
\hline & 2139 & 0.03 & 2.0 & 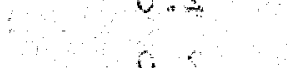 & 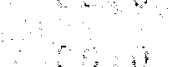 & & \\
\hline & 2253 & 0.03 & 2.0 & & \% & & \\
\hline \multirow[t]{8}{*}{ oct. 7} & 0010 & 0.03 & 2.0 & 8 & $\begin{array}{l}0, \\
00,1\end{array}$ & $\therefore+3$ & \\
\hline & 0423 & 0.03 & 20 & 3 & $\because 10$ & $\cdots$ & \\
\hline & 0824 & 0.03 & 2.0 & 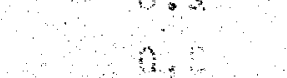 & $a$ & $\because, \infty$ & \\
\hline & 1037 & 0.03 & 2.0 & 0 & 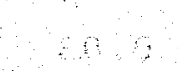 & 3.8 & \\
\hline & 1229 & 0.03 & 2.0 & $8 s$ & $6:$ & $a_{1}$ & \\
\hline & 1407 & 0.03 & 2.0 & 0.8 & 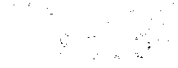 & s & \\
\hline & 1436 & 0.03 & 2.0 & $=\infty$ & $\because \quad \therefore$ & & \\
\hline & 1506 & 0.03 & 2.0 & & & & \\
\hline
\end{tabular}


TABLE B $\div 2$ (continued) .

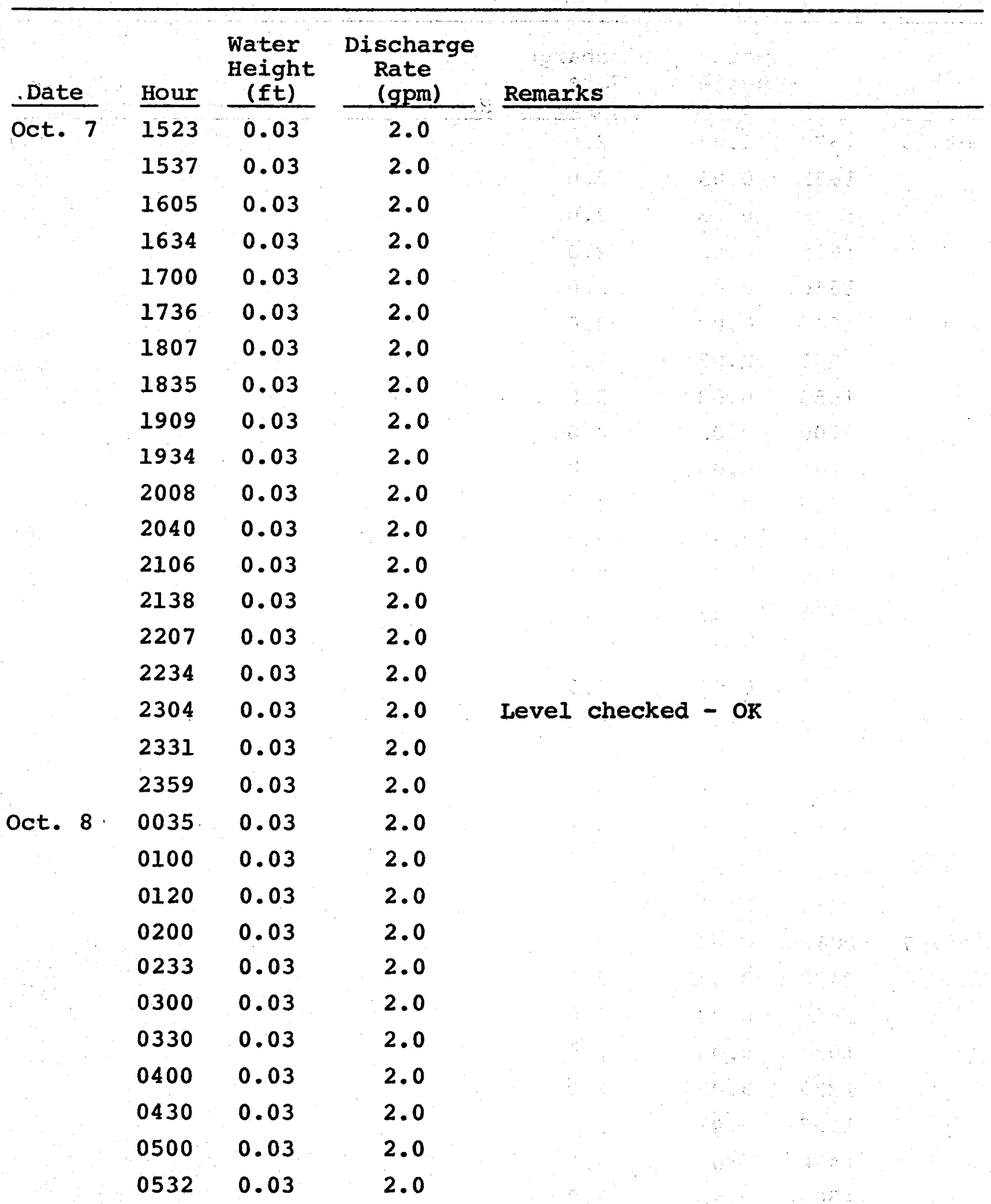


TABLE B-2 (continued) .

\begin{tabular}{|c|c|c|c|c|c|c|c|}
\hline Date. & Hour & $\begin{array}{l}\text { Water } \\
\text { Height } \\
\text { (ft) }\end{array}$ & $\begin{array}{c}\text { Discharge } \\
\text { Rate } \\
\text { (gpm) }\end{array}$ & $\begin{array}{l}\text { ofos } \\
\text { Remarks }\end{array}$ & 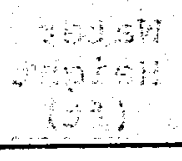 & 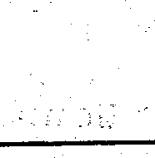 & $20+1$ \\
\hline \multirow[t]{20}{*}{ Oct. 8} & 0602 & 0.03 & 2.0 & Level OK & 60 & a & 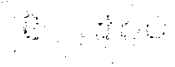 \\
\hline & 0631 & 0.03 & 2.0 & 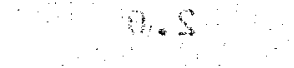 & 80 & bis & \\
\hline & 0700 & 0.03 & 2.0 & 0.5 & 8.0 & $20:$ & \\
\hline & 0800 & 0.03 & 2.0 & $\therefore 5$ & 80,0 & 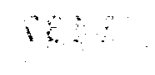 & \\
\hline & 0900 & 0.03 & 2.0 & $\therefore$ & $=240$ & 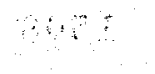 & \\
\hline & 1000 & 0.03 & 2.0 & 0 & 50.0 & Aक & \\
\hline & 1101 & 0.03 & 2.0 & $a:$ & $4 \times$ & $6 \%$ & \\
\hline & 1201 & 0.03 & 2.0 & 1.5 & 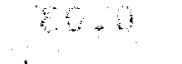 & 21 & \\
\hline & 1300 & 0.03 & 2.0 & 0.5 & 80 & $\min$ & \\
\hline & 1405 & 0.03 & 2.0 & $=5$ & $\cdots$ & 903 & \\
\hline & 1505 & 0.03 & 2.0 & 6. & $\mathrm{cos}$ & 6 & \\
\hline & 1604 & 0.03 & 2.0 & $3=$ & 00 & $6 \div 2$ & \\
\hline & 1705 & 0.03 & 2.0 & $\therefore$ & $\varepsilon:=$ & $8: 2$ & \\
\hline & 1808 & 0.03 & $\operatorname{Iog}_{2}=0^{28} L^{3}$ & 0.6 & 80 & 30 & \\
\hline & 1904 & 0.03 & 2.0 & 0.5 & 8.9 & 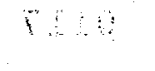 & \\
\hline & 2008 & 0.03 & 2.0 & 0.5 & 50.9 & 630 & \\
\hline & 2100 & 0.03 & 2.0 & 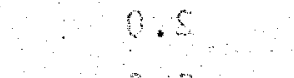 & 80 & 800 & \\
\hline & 2200 & 0.03 & 2.0 & 0. & 8.0 & $\therefore$ & \\
\hline & 2300 & 0.03 & 2.0 & 6 & 50. & $\Delta \hat{x} \theta$ & \\
\hline & 0000 & 0.03 & 2.0 & 1,1 & $-9,0$ & +10 & \\
\hline \multirow[t]{11}{*}{ oct. 9} & 0100 & 0.03 & 2.0 & 0.3 & 90 & 60 & \\
\hline & 0200 & 0.03 & 2.0 & 0.8 & 4.4 & 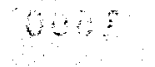 & \\
\hline & 0300 & 0.03 & 2.0 & 0.2 & 0.0 & ects & \\
\hline & 0400 & 0.03 & 2.0 & 0.6 & 100 & $\therefore n$ & $1 I$ \\
\hline & 0500 & 0.03 & 2.0 & 4 & $6 u$ & 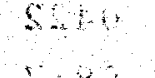 & \\
\hline & 0600 & 0.03 & 2.0 & $\begin{array}{l}0.9 \\
0.8\end{array}$ & bon & 8 & \\
\hline & 0700 & 0.03 & 2.0 & 9. & $\begin{array}{l}50 \\
80\end{array}$ & & \\
\hline & 0800 & 0.03 & 2.0 & 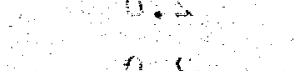 & $\begin{array}{l}2+3 \\
x+3\end{array}$ & 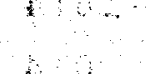 & \\
\hline & 0900 & 0.03 & 2.0 & 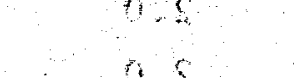 & 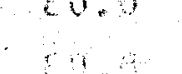 & -2 & \\
\hline & 1000 & 0.03 & 2.0 & $\Leftrightarrow$ & ris & & \\
\hline & 1100 & 0.03 & $\operatorname{mat} 2 \div 0 \ln$ & & & & \\
\hline
\end{tabular}


TABLE B-2(continued) .

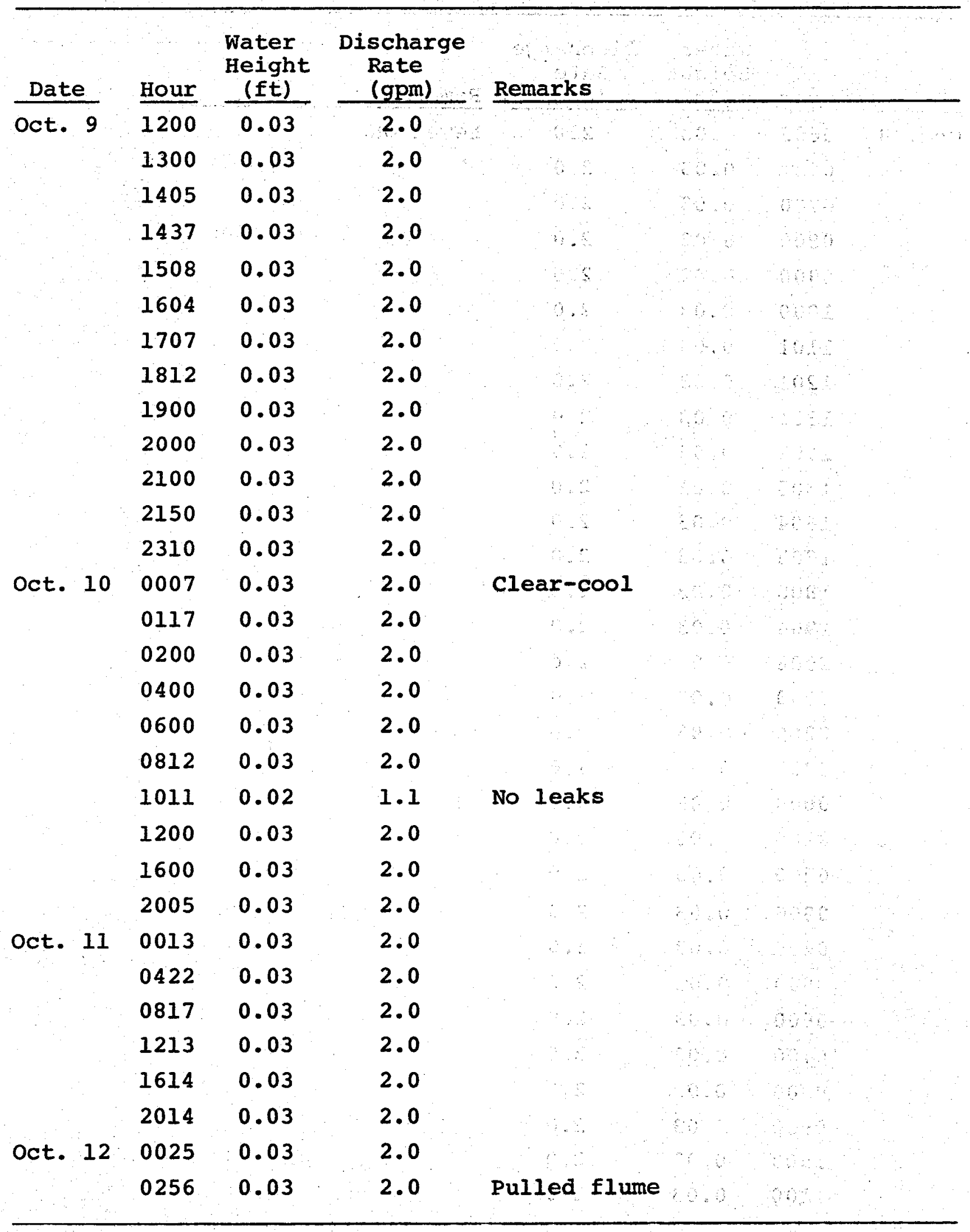




\section{APPENDIX B}

TABLE B-3. DISCHARGE MEASUREMENTS AT FLUME NO, 2, GILA HOT SPRINGS, NEW MEXICO; IN OCTOBER 1981

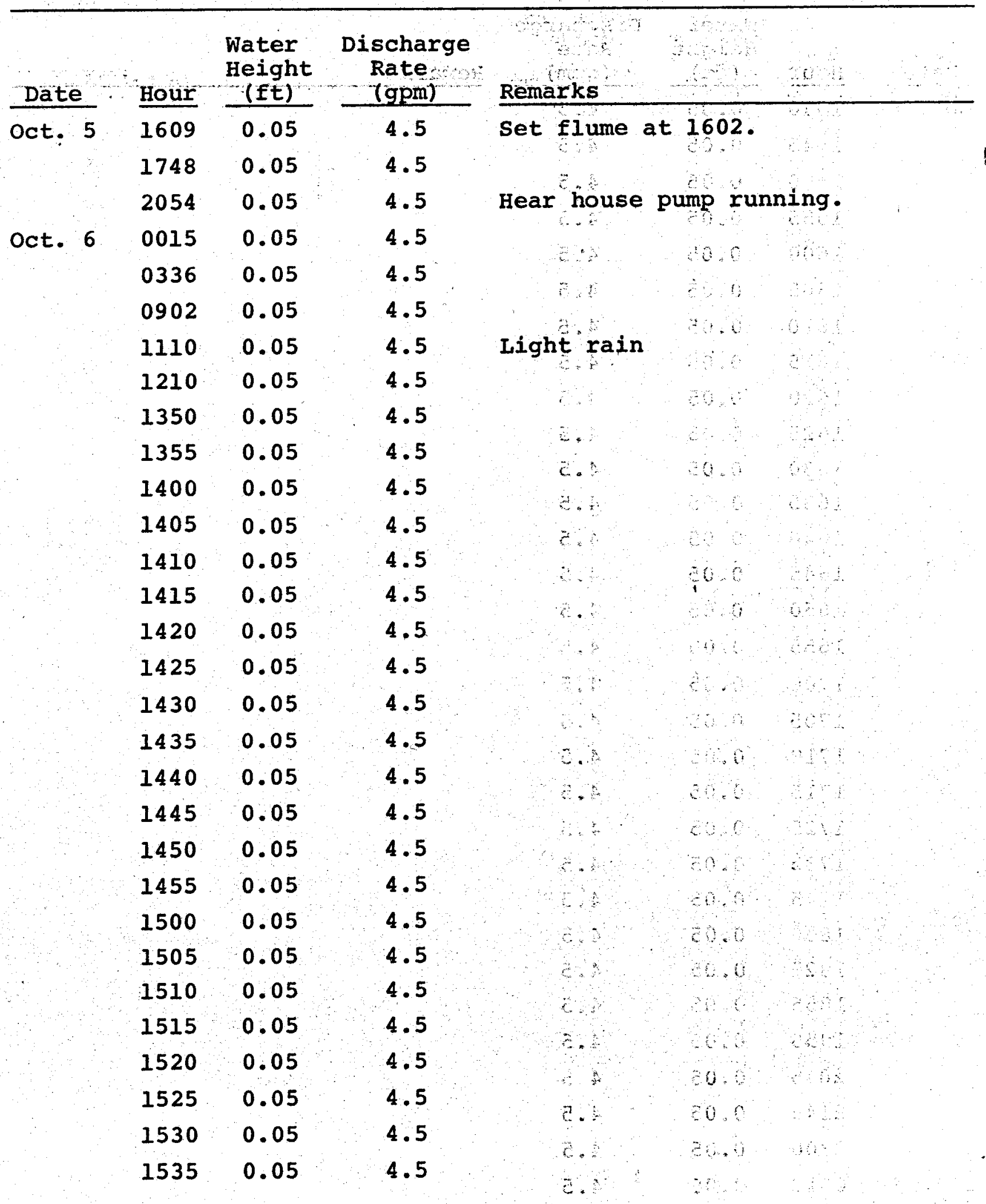


T.ABLE B-3 (continued) .

\begin{tabular}{|c|c|c|c|c|c|}
\hline Date & Hour & $\begin{array}{l}\text { Water } \\
\text { Height } \\
\text { (ft) }\end{array}$ & $\begin{array}{c}\text { Discharge } \\
\text { Rate } \\
\text { (gpm) } \\
\end{array}$ & Remarks & \\
\hline \multirow[t]{30}{*}{ oct. 6} & 1540 & 0.05 & 4.5 & 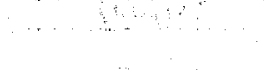 & \\
\hline & 1545 & 0.05 & 4.5 & & \\
\hline & 1550 & 0.05 & 4.5 & & \\
\hline & 1555 & 0.05 & 4.5 & & \\
\hline & 1600 & 0.05 & 4.5 & & \\
\hline & 1605 & 0.05 & 4.5 & & \\
\hline & 1610 & 0.05 & 4.5 & & \\
\hline & 1615 & 0.05 & 4.5 & & \\
\hline & 1620 & 0.05 & 4.5 & & \\
\hline & 1625 & 0.05 & 4.5 & & \\
\hline & 1630 & 0.05 & 4.5 & & \\
\hline & 1635 & 0.05 & 4.5 & & \\
\hline & 1640 & 0.05 & 4.5 & & \\
\hline & 1645 & 0.05 & 4.5 & & \\
\hline & 1650 & 0.05 & 4.5 & & \\
\hline & 1655 & 0.05 & 4.5 & & \\
\hline & 1700 & 0.05 & 4.5 & & \\
\hline & 1705 & 0.05 & 4.5 & & \\
\hline & 1710 & 0.05 & 4.5 & & \\
\hline & 1715 & 0.05 & 4.5 & & \\
\hline & 1725 & 0.05 & 4.5 & & \\
\hline & 1735 & 0.05 & 4.5 & & \\
\hline & 1745 & 0.05 & 4.5 & & \\
\hline & 1800 & 0.05 & 4.5 & & \\
\hline & 1825 & 0.05 & 4.5 & & \\
\hline & 1855 & 0.05 & 4.5 & & \\
\hline & 1955 & 0.05 & 4.5 & & \\
\hline & 2045 & 0.05 & 4.5 & & \\
\hline & 2145 & 0.05 & 4.5 & & \\
\hline & 2300 & 0.05 & 4.5 & & \\
\hline Oct. 7 & 0012 & 0.05 & 4.5 & & \\
\hline
\end{tabular}


TABLE B-3 (continued) .

\begin{tabular}{|c|c|c|c|c|c|c|c|}
\hline Date & Hour & $\begin{array}{l}\text { Water } \\
\text { Height } \\
\text { (ft) } \\
\end{array}$ & $\begin{array}{c}\text { Discharge } \\
\text { Rate } \\
\text { (gpm) }\end{array}$ & $\begin{array}{c}\text { efrowat } \\
\text { os } \\
\text { Remarks } \\
\end{array}$ & 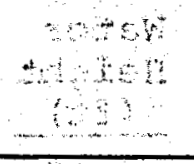 & 28 & $\begin{array}{r}3.6 \\
\ldots\end{array}$ \\
\hline \multirow[t]{25}{*}{ oct. 7} & 0426 & 0.05 & 4.5 & 2. & 60 & 80 & \\
\hline & 0826 & 0.05 & 4.5 & a & 26.3 & 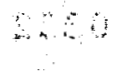 & \\
\hline & 1039 & 0.05 & 4.5 & 2.1 & 80.0 & 5.2 & \\
\hline & 1229 & 0.05 & 4.5 & $0 . \frac{1}{2}$ & $\cos$ & 250 & \\
\hline & 1405 & 0.05 & 4.5 & 2.2 & 00.0 & 80 & \\
\hline & 1438 & 0.05 & 4.5 & 2. & 20.0 & 8 & \\
\hline & 1509 & 0.05 & 4.5 & 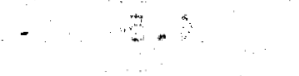 & 20.0 & $\operatorname{sen}$ & \\
\hline & 1519 & 0.05 & 4.5 & 2. & 20.0 & 80 & \\
\hline & 1539 & 0.05 & 4.5 & 8. & 20.0 & $s$ & \\
\hline & 1607 & 0.05 & 4.5 & $E$. & 20.0 & 3 & \\
\hline & 1635 & 0.05 & 4.5 & z. & 20.0 & $\therefore 8$ & \\
\hline & 1705 & 0.05 & 4.5 & 2, & to. & 50 & \\
\hline & 1739 & 0.05 & 4.5 & $\bar{s}$ & cos & $\therefore$ & \\
\hline & 1810 & 0.05 & 4.5 & c. & 20.0 & sass & \\
\hline & 1836 & 0.05 & 4.5 & $\ldots$ & 20,0 & 800 & \\
\hline & 1910 & 0.05 & 4.5 & 2. & $m$ & 21 & \\
\hline & 1936 & 0.05 & 4.5 & $\alpha, n$ & 26 & $\sec$ & \\
\hline & 2009 & 0.05 & 4.5 & 6. & $80, ?$ & 30 & \\
\hline & 2042 & 0.05 & 4.5 & $8, b$ & 600 & 4 & \\
\hline & 2109 & 0.05 & 4.5 & 6.6 & 80 & $\mathrm{mb}$ & \\
\hline & 2140 & 0.05 & 4.5 & 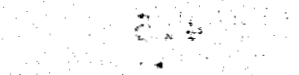 & 200 & 80 & \\
\hline & 2209 & 0.05 & 4.5 & B. & 20.0 & dens & \\
\hline & 2236 & 0.05 & 4.5 & 2, & con & 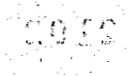 & \\
\hline & 2306 & 0.05 & 4.5 & 2. & 80.0 & 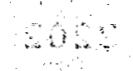 & \\
\hline & 2332 & 0.05 & 4.5 & 2. & 80.0 & 80 & \\
\hline \multirow[t]{6}{*}{ oct. 8} & 0001 & 0.05 & 4.5 & $e$. & $20, a$ & $=30$ & 8.250 \\
\hline & 0036 & 0.05 & 4.5 & $e_{0}$ & 80. & 800 & \\
\hline & 0102 & 0.05 & 4.5 & $a$. & 20.6 & $8 s$ & \\
\hline & 0132 & 0.05 & 4.5 & $d A$ & 20.0 & $\sec$ & \\
\hline & 0201 & 0.05 & 4.5 & $\therefore$ & 80.0 & $50: 0$ & \\
\hline & 0235 & 0.05 & 4.5 & c. & 60.0 & 800 & \\
\hline
\end{tabular}


TABLE B-3 (continued) .

\begin{tabular}{|c|c|c|c|c|c|}
\hline Date & Hour & $\begin{array}{l}\text { Water } \\
\text { Height } \\
\text { (ft) }\end{array}$ & $\begin{array}{c}\text { Discharge } \\
\text { Rate } \\
\text { (gpm) }\end{array}$ & Remarks & \\
\hline \multirow[t]{25}{*}{ Oct. 8} & 0302 & 0.05 & 4.5 & & \\
\hline & 0332 & 0.05 & 4.5 & & \\
\hline & 0402 & 0.05 & 4.5 & & $x=$ \\
\hline & 0432 & 0.05 & 4.5 & & $d$ \\
\hline & 0502 & 0.05 & 4.5 & $\therefore$ & 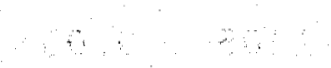 \\
\hline & 0535 & 0.05 & 4.5 & $\because$ & \& \\
\hline & 0605 & 0.05 & 4.5 & Level OK. & $\because$ \\
\hline & 0633 & 0.05 & 4.5 & $\because$ & 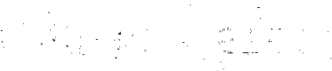 \\
\hline & 0702 & 0.05 & 4.5 & & \\
\hline & 0802 & 0.05 & 4.5 & $\therefore$ & $\because$ \\
\hline & 0902 & 0.05 & 4.5 & $\therefore$ & $\because \ldots$ \\
\hline & 1002 & 0.05 & 4.5 & $\therefore$ & $\therefore \quad \therefore$ \\
\hline & 1103 & 0.05 & 4.5 & 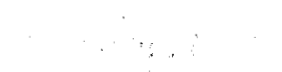 & $\therefore \quad$ \\
\hline & 1202 & 0.05 & 4.5 & & $\therefore$ \\
\hline & 1302 & 0.05 & 4.5 & & 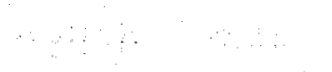 \\
\hline & 1408 & 0.05 & 4.5 & & \\
\hline & 1506 & 0.05 & 4.5 & & \\
\hline & 1606 & 0.05 & 4.5 & & $\therefore$ \\
\hline & 1708 & 0.05 & 4.5 & & \\
\hline & 1805 & 0.05 & 4.5 & & $\Leftrightarrow$ \\
\hline & 1907 & 0.05 & 4.5 & & \\
\hline & 2005 & 0.05 & 4.5 & . & $\cdots: \quad \cdots$ \\
\hline & 2102 & 0.05 & 4.5 & 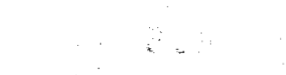 & $\because \quad \therefore$ \\
\hline & 2202 & 0.05 & 4.5 & 3 & 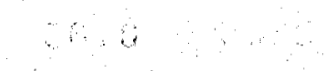 \\
\hline & 2302 & 0.05 & 4.5 & $\ldots$ & $\therefore$ \\
\hline \multirow[t]{6}{*}{ Oct. 9} & 0002 & 0.05 & 4.5 & $\therefore$ & $\therefore$ \\
\hline & 0102 & 0.05 & 4.5 & $\varepsilon_{*}$ & $\therefore$ \\
\hline & 0202 & 0.05 & 4.5 & $\ldots$ & $\therefore$ \\
\hline & 0302 & 0.05 & 4.5 & & $\cdots$ \\
\hline & 0402 & 0.05 & 4.5 & $\because$ & $\because \quad+\quad$ \\
\hline & 0403 & 0.05 & 4.5 & & $8+5<$ \\
\hline
\end{tabular}


TABLE B-3 (continued) .

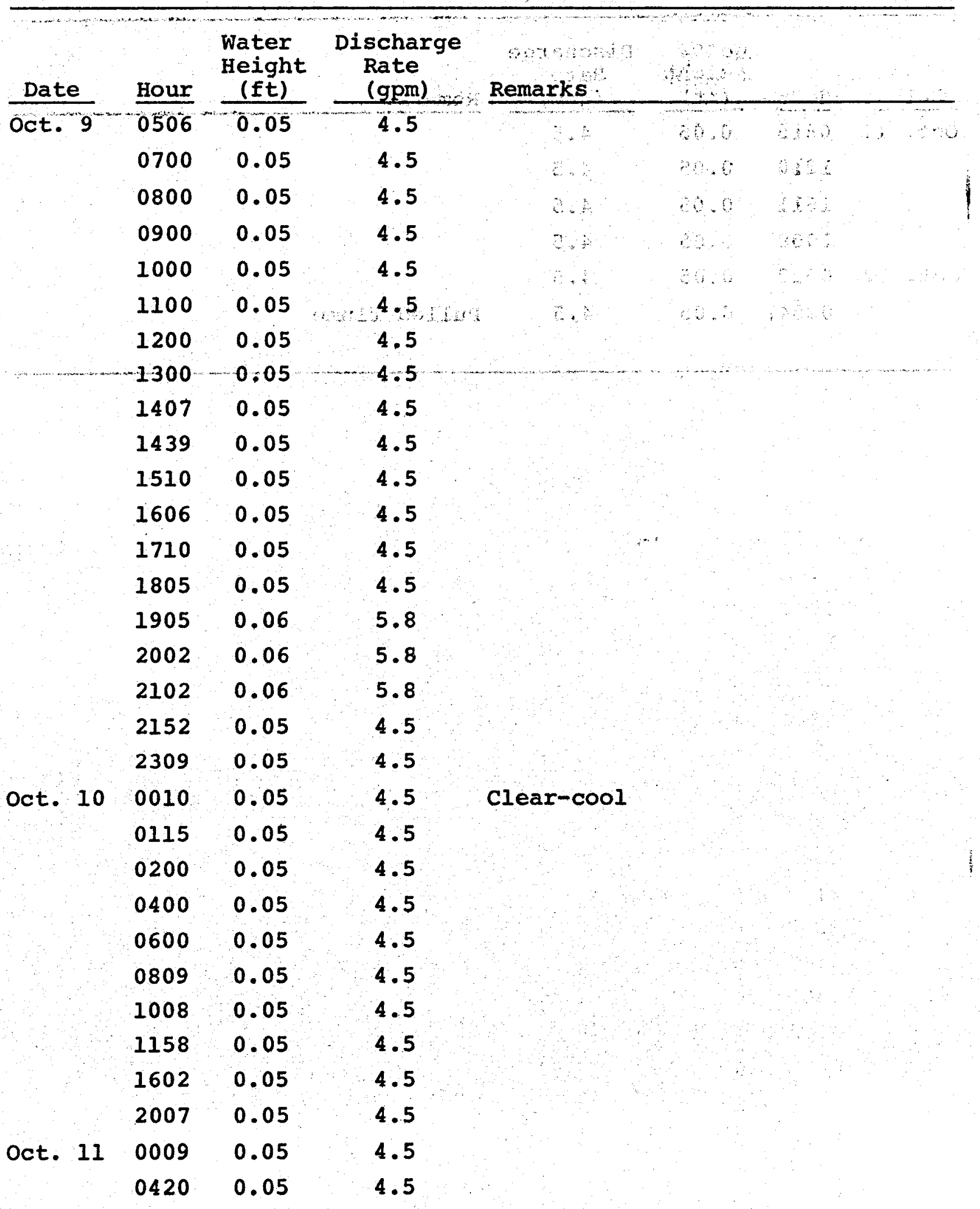


TABLE B-3 (continued) .

\begin{tabular}{|c|c|c|c|c|c|}
\hline Date & Hour & $\begin{array}{l}\text { Water } \\
\text { Height } \\
\text { (ft) } \\
\end{array}$ & $\begin{array}{c}\text { Discharge } \\
\text { Rate } \\
\text { (gpm) } \\
\end{array}$ & Remarks & \\
\hline \multirow[t]{4}{*}{ Oct. 11} & 0815 & 0.05 & 4.5 & $=$ & 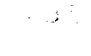 \\
\hline & 1210 & 0.05 & 4.5 & & \\
\hline & 1611 & 0.05 & 4.5 & & \\
\hline & 2008 & 0.05 & 4.5 & & \\
\hline \multirow[t]{2}{*}{ oct. 12} & 0022 & 0.05 & 4.5 & . & \\
\hline & 0254 & 0.05 & 4.5 & Pulled flume & \\
\hline
\end{tabular}


APPENDIX C

STEP TEST DATA FROM

WELL CAMPBELL ET AL. NO. 2 AND

NORTH AND SOUTH OBSERVATION WELIS 


\section{APPENDIX C}

TABLE C-1. Cambie11 et el. H2 - averase discharse bu sbers

\begin{tabular}{|c|c|c|c|c|}
\hline STEF & DCT & $\begin{array}{l}\text { RATE } \\
81 \text { HOUF }\end{array}$ & $\begin{array}{l}\text { ELAFGEN } \\
\text { TTME (MTN) }\end{array}$ & $\begin{array}{c}\text { AUEFAGE } \\
\text { DTSCHARGE (GFM) }\end{array}$ \\
\hline 1 & 6 & $\begin{array}{l}14: 15.0 \\
14: 45.0\end{array}$ & $\begin{array}{r}0.0 \\
30.0\end{array}$ & 17.5 \\
\hline 2 & & $\begin{array}{l}14: 45.0 \\
15: 15.0\end{array}$ & $\begin{array}{l}30.0 \\
60.0\end{array}$ & 29.9 \\
\hline 3 & & $\begin{array}{l}15: 15.0 \\
15: 45.0\end{array}$ & $\begin{array}{l}60.0 \\
90.0\end{array}$ & 35.8 \\
\hline 4 & & $\begin{array}{l}15: 45.0 \\
16: 15.0\end{array}$ & $\begin{array}{r}90.0 \\
120.0\end{array}$ & 41.3 \\
\hline 5 & & $\begin{array}{l}16: 15.0 \\
16: 45.0\end{array}$ & $\begin{array}{l}120.0 \\
150.0\end{array}$ & 50.9 \\
\hline
\end{tabular}




\section{APPENDIX C}

TABLE C-2

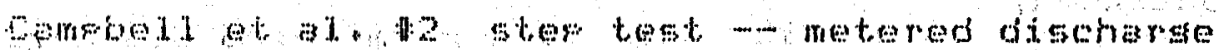

- - OATE - ELAFSER

\section{DCT HOUF TIME}

198 (BIT)

6. $14: 15: 0$

$14: 19.0$

$14 \div 24: 0$

$14: 29+0$

4435.0

$14: 41,0$

$14: 14 \cdot 0$

$14: 48.0$

$14: 54.0$

$1.5 \div 4.0$

$15 \% 90$

$15: 1.9 .0$

$15: 20-0$

$15: 25.0$

95.30 .0

$15: 35.0$

$15: 40.0$

$15: 44.0$

$15: 51.0$

154550

$16: 0.0$

$16: 50$

$16+10,0$

$16: 14.0$

$16: 20: 0$

$16: 25+0$
(TI, MTN)

MTETEF

FEADTNG

TOTAL.

IITSCHAREE

(U, GAL $\}$

0.0

4.0

9.0

1.4 .0

20.0

26.0

$29 \cdot 0$

33.0

39.0

49.0

54.0

59.0

65.0

70.0

$75 \cdot 0$

80.0

85.0

89.0

96.0

100.0

105,0

110.0

115.0

119.0

125.0

130.0
464

4258

4351

4455

4557

4607

4710

4892

3192

5340

5489

5693

5872

6052

6231

6409

6552

6832

6997

7203

7410

7617

7782

8089

8334
205

298

402

504

554

657

839

1139

1287

1.436

1640

1819

1999

2178

2356

2499

2779

2944

3150

3357

3564

3729

4036

4281
FUNNTNE

AUERAGE
(U/TI, GFM)

V

(GAL) (MIN)

$U / T$

$111 \therefore 27.6$
22.8

$21 \cdot 3$

$20+1$

$19 \cdot 4$

19.1

19.9

21.5

23.2

23.8

111

$9 ! 5$

93

104

102

51

103

182

300

149

1.49

$24 \cdot 3$

25.2

26.0

26.7

27.2

27.7

$28+1$

28.9

29.4

30.0

30.5

31.0

31.3

$32 \cdot 3$

32.9

20

1.80

180

179

$1>9$

143

280

165

207

206

207

165

307

345
4.

5.0

50

6.0

6.0

3.0

5.0

5.0

6.0

5.0

5.0

5.0

5.0

4.0

7.0

4.0

5.0

5.0

5.0

4.0

6.0

5.0

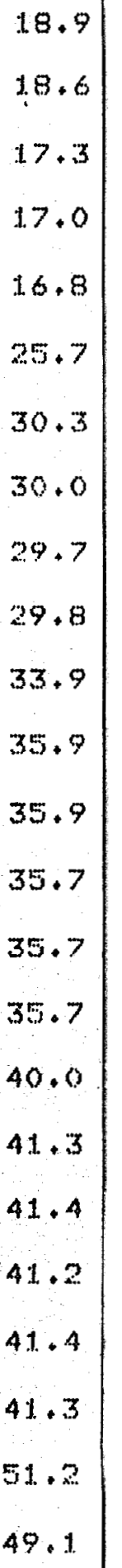

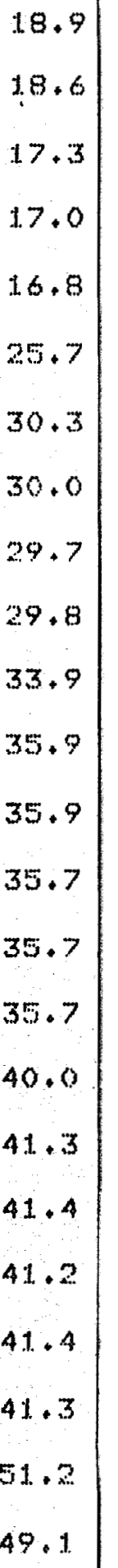

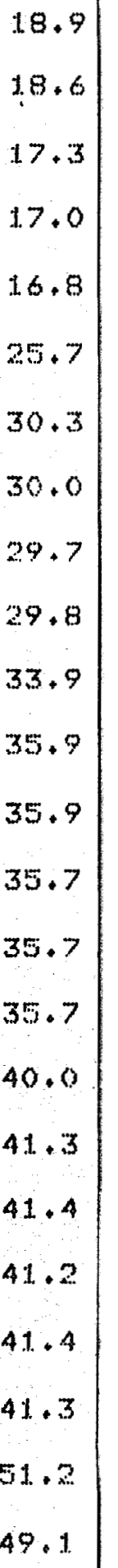

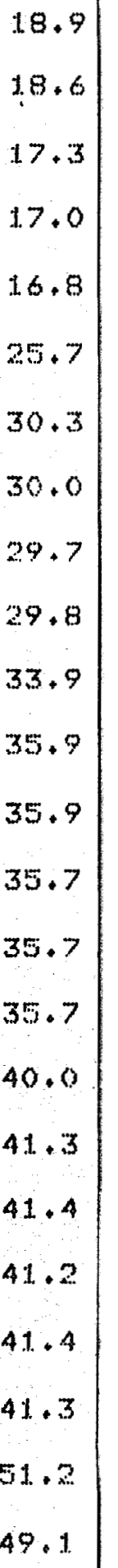

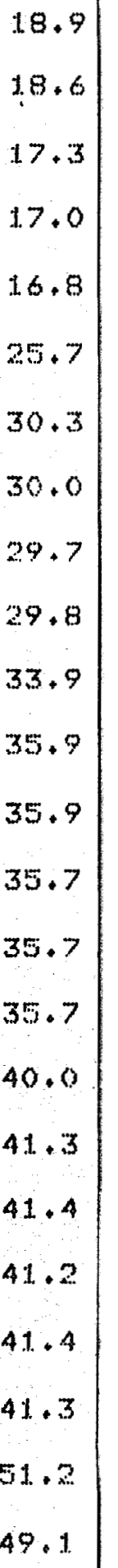

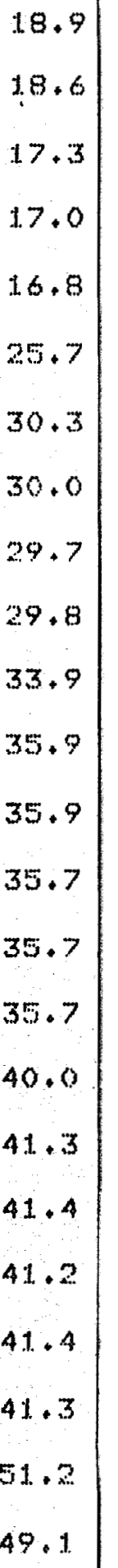


TABLE C-2 (continued)

Calmbejl et a 1. Ha ster test - metered discharse

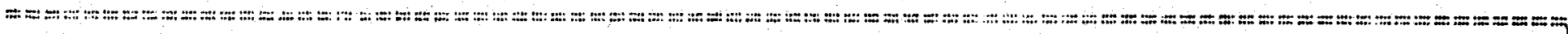

\begin{tabular}{|c|c|c|c|c|c|c|c|c|}
\hline$-\cdots-$ & UATE- - - & ELAFSEI & & TOTAL & FUNNTNG & $---I N$ & FEMENT & Al_- \\
\hline $\begin{array}{l}\text { OCT } \\
1981\end{array}$ & $\begin{array}{l}\text { HOUF } \\
\text { (MDT) }\end{array}$ & $\begin{array}{l}\text { TIME } \\
\text { (TI, MIN) }\end{array}$ & $\begin{array}{l}\text { METEF: } \\
\text { FEAIING }\end{array}$ & $\begin{array}{l}\text { TISSCHAFGE } \\
\text { (U, GAL) }\end{array}$ & $\begin{array}{l}\text { AUEFAGE } \\
(U / T 1, \text { GFM) }\end{array}$ & $\begin{array}{l}U \\
\text { (GAL) }\end{array}$ & (MIN) & $\begin{array}{l}3 / \mathrm{T} \\
\text { (GFM) }\end{array}$ \\
\hline & $-\cdots$ & $-\infty-\infty-\infty$ & $-\infty$ & $-\cdots-\infty$ & $-3-x-m$ & $-\infty-\infty$ & & $-\infty$ \\
\hline 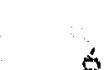 & $16: 30.0$ & 175.0 & 8589 & $4=36$ & 6 & 255 & 5.0 & 50.9 \\
\hline & & & & & ortor & 510 & 10.0 & 31.0 \\
\hline & $16: 40.0$ & 1.45 .0 & 9099 & 5046 & 34.8 & & & \\
\hline & $16: 45 \cdot 0$ & 150.0 & 9353 & 5300 & 35.3 & & 1.0 & 7 \\
\hline
\end{tabular}




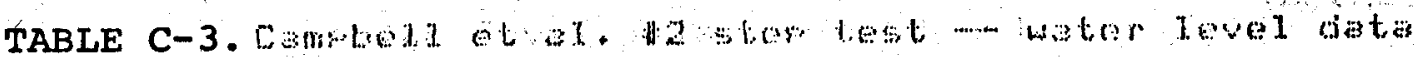

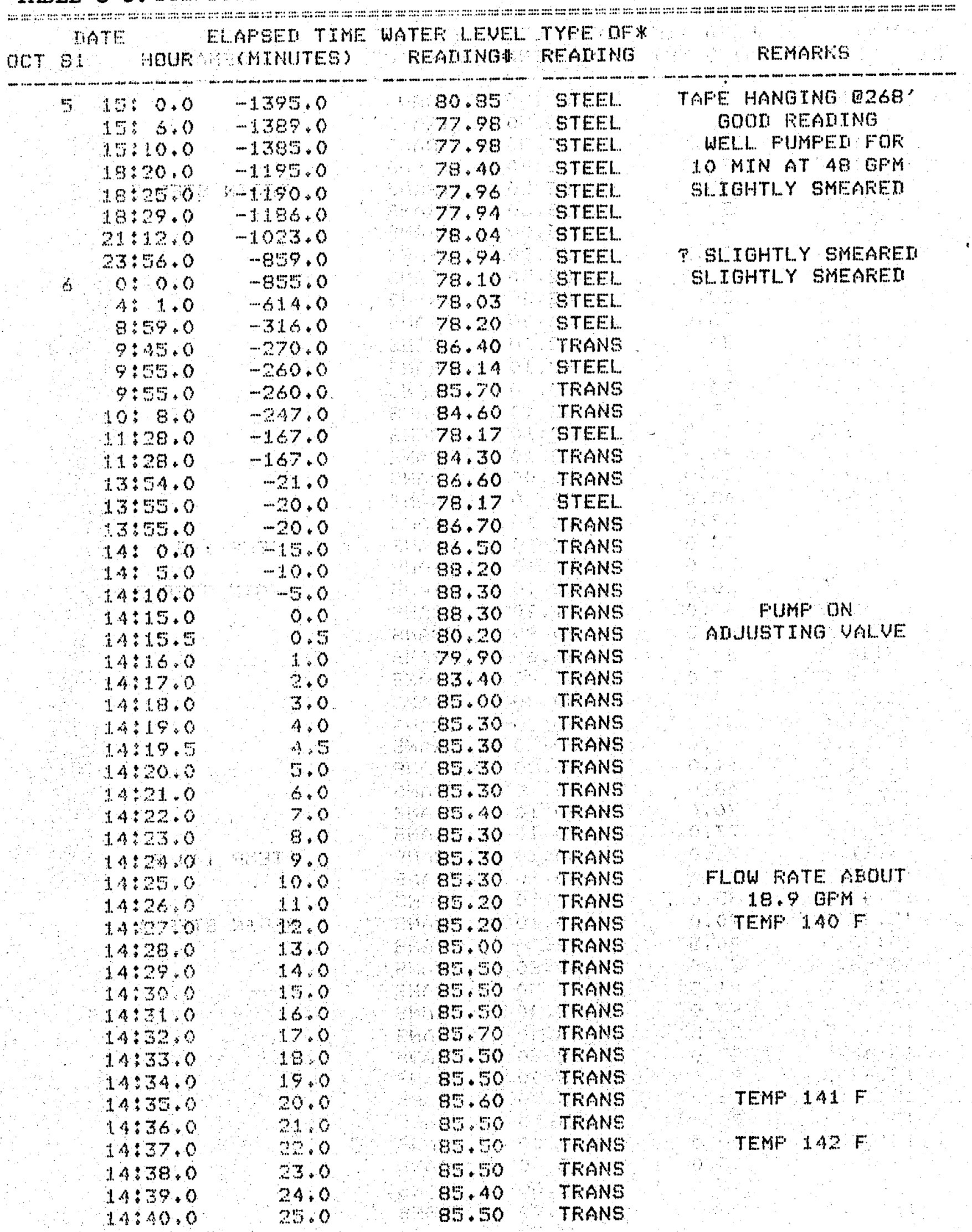

81

W. SUMMES ANO ASSOCTATES, TNC. 
TABLE C-3 (continued)

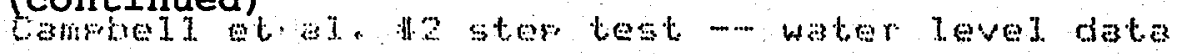

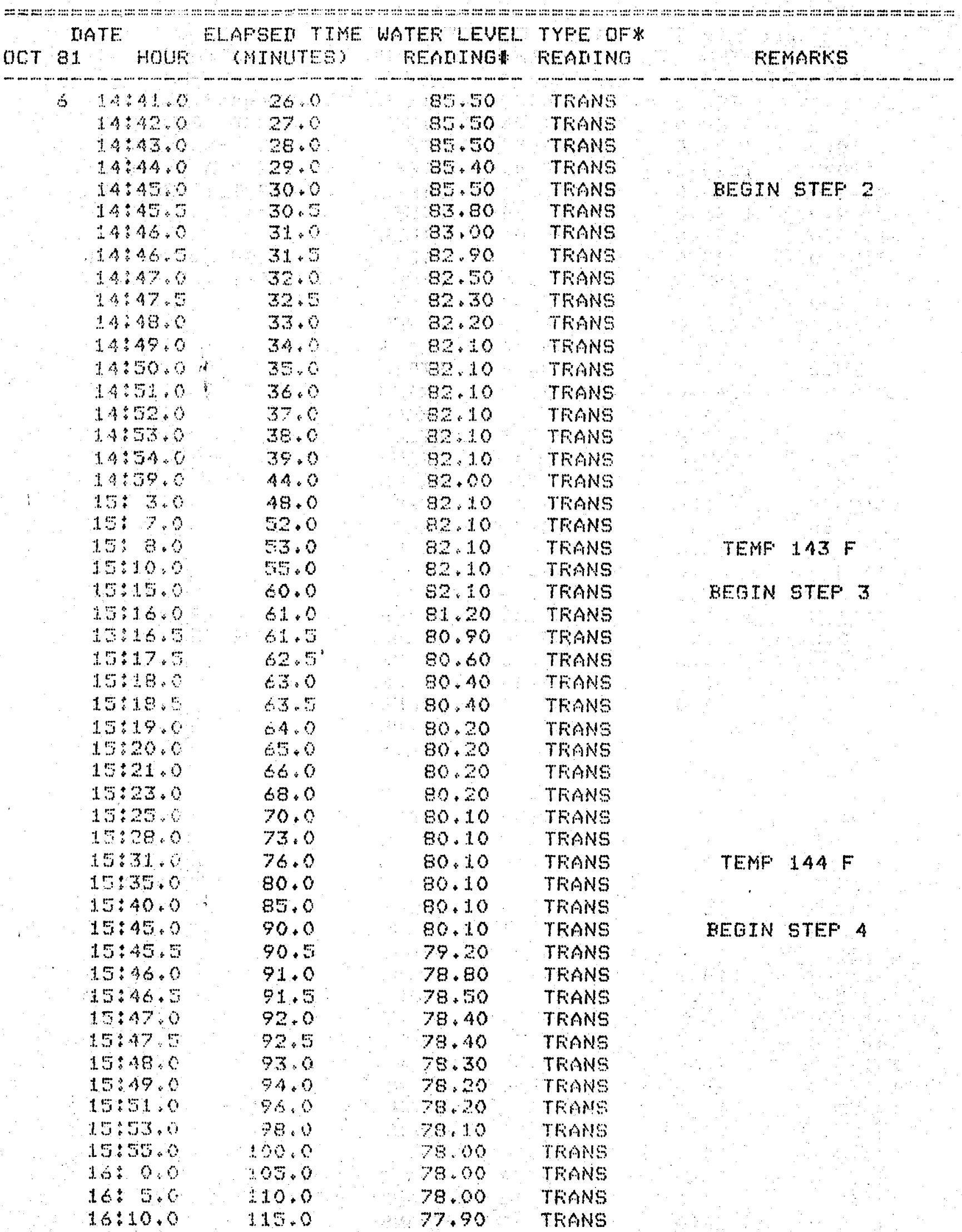


TABLE C-3 (continued)

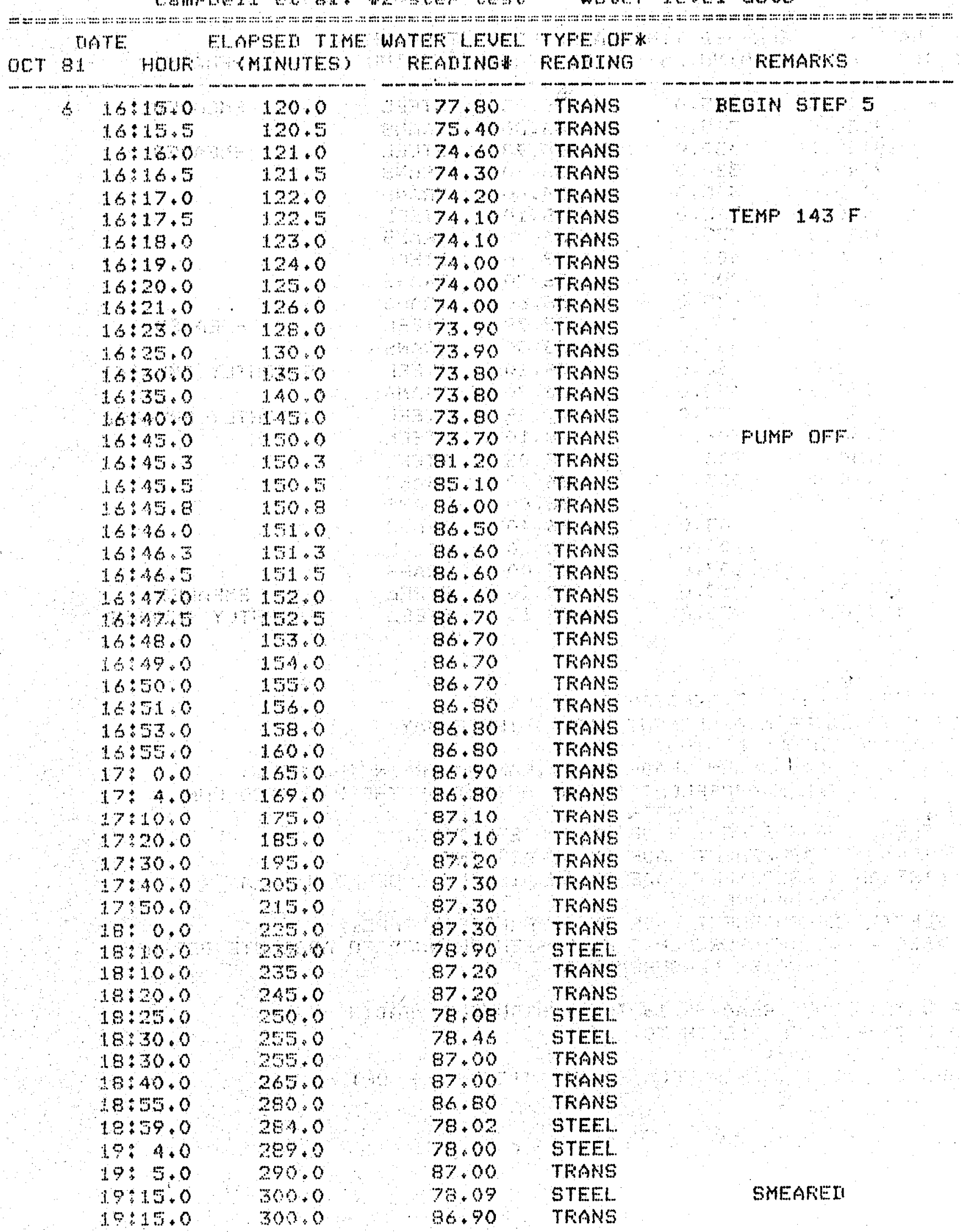


TABLE C-3 (continued)

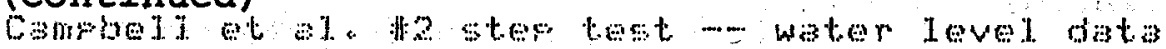

\begin{tabular}{|c|c|c|c|c|c|c|}
\hline \multirow{2}{*}{ ocr } & \multicolumn{2}{|c|}{ DATE } & \multirow{2}{*}{$\begin{array}{c}\text { ELAFSEO TIME } \\
\text { (MTNUTES) }\end{array}$} & \multirow{2}{*}{$\begin{array}{l}\text { WATEF LEVEL } \\
\text { FEATINGH }\end{array}$} & \multirow{2}{*}{$\begin{array}{l}\text { TYFE OF* } \\
\text { FEAITMG }\end{array}$} & \multirow[b]{2}{*}{ FEMAFNS } \\
\hline & 81 & HOUF & & & & \\
\hline & $b$ & $19: 30.0$ & 315.0 & 78.03 & STEEL & SMEAFEI \\
\hline & & $19: 30.0$ & 315.0 & 86.80 & TFANS & \\
\hline & & $19: 45.0$ & 330.0 & 76.78 & STEEL & SMEAFED \\
\hline & & $19: 45.0$ & $3,30.0$ & $86+70$ & TRANS & \\
\hline & & $20: 0.0$ & 345.6 & 86.60 & TFANS & \\
\hline & & $20: 30.0$ & 375.6 & 78.10 & STEEI.. & \\
\hline & & $20: 30.0$ & 370.0 & 86.70 & TFANS & \\
\hline & & $21+0+0$ & 405.0 & 78.10 & STEEL & \\
\hline & & $21: 0.0$ & 405.0 & 86.70 & TRANS: & \\
\hline & & $21 \div 30 \cdot 0$ & 435.0 & 86.60 & TFANS & \\
\hline & & $22 \div 0.0$ & $365+0$ & 78.98 & STEEL & SMEAFEN \\
\hline & & $22: 0.0$ & 462.0 & 86.50 & TEANS & \\
\hline & & $22: 3.0$ & 468.0 & 78.10 & STEEI. & SLIGHTLY SMEAREI \\
\hline & & $22: 30.0$ & 495.0 & 86.70 & TFANS & \\
\hline & & $22 \div 32,0$ & 497.0 & $79 \cdot 39$ & $S T E E$ & SLTGHTLY SMEARED \\
\hline & & $22: 36.0$ & 501.6 & 78.10 & STEEI. & \\
\hline & & $22: 40.0$ & 505.0 & 78.08 & STEEI. & \\
\hline & & $23: 10.0$ & $535+0$ & 86.70 & TrAns & \\
\hline 1 & 7 & $0: 0.0$ & 585.0 & 86.80 & TFANS & \\
\hline & & $4: 38.0$ & $865+0$ & $86 \cdot 40$ & TFANS & \\
\hline & & $8: 42: 0$ & $\therefore 107: 0$ & 78.20 & STEE & \\
\hline & & $8: 42.0$ & 1107.0 & 85.00 & TFAMS & \\
\hline & & $11: 7.0$ & $1252 \cdot 0$ & $78 \cdot 10$ & sTFil & SMEAFEI \\
\hline & & $11 \div 10.0$ & 1255.0 & 78.13 & STEEI. & SL TGHTLY SMEAREI \\
\hline
\end{tabular}

WTHE TYFE OE FEARAN OENOTES THE TYFE OF

WEFTH TO WATES MEASUEEMENT MAOE. THESE MAY

BE ANY OF THE TOLOWTNG:

TEANS- MEAGUETENT MAOE EY A TRANSWUEEF TN THE WELL.

THE MEASUEEMENT TS THE HETOHT OF THE WATEF OOUNAN AEQUE THE OEWSOF

STEE:- MEAOUEMENT MTE BY A OTEEL TAFE.

ATF: MEASEEMENT MATE EY AN ATFLTME.

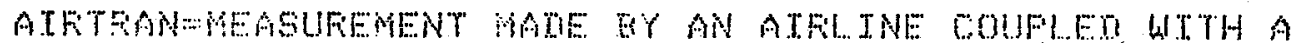

TEANSTIOEF.

ELECT: MEASUFEMENT MATE BY AN ELECTFTC TAFE.

ABSO :- MLI. MEASUREMENTS HAUE EEEN CHANGEX TO AESOLUTE DEFTHTO-WATEE MEASUREMENTS.

HTHE WATEF LEUEL REAITNG TS THE TNGTFUMENT REARTNG

MADE TO FTNT THE MEPTH TO WTEF。

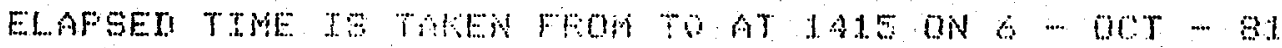


TABLE C-4.

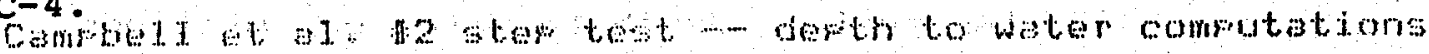

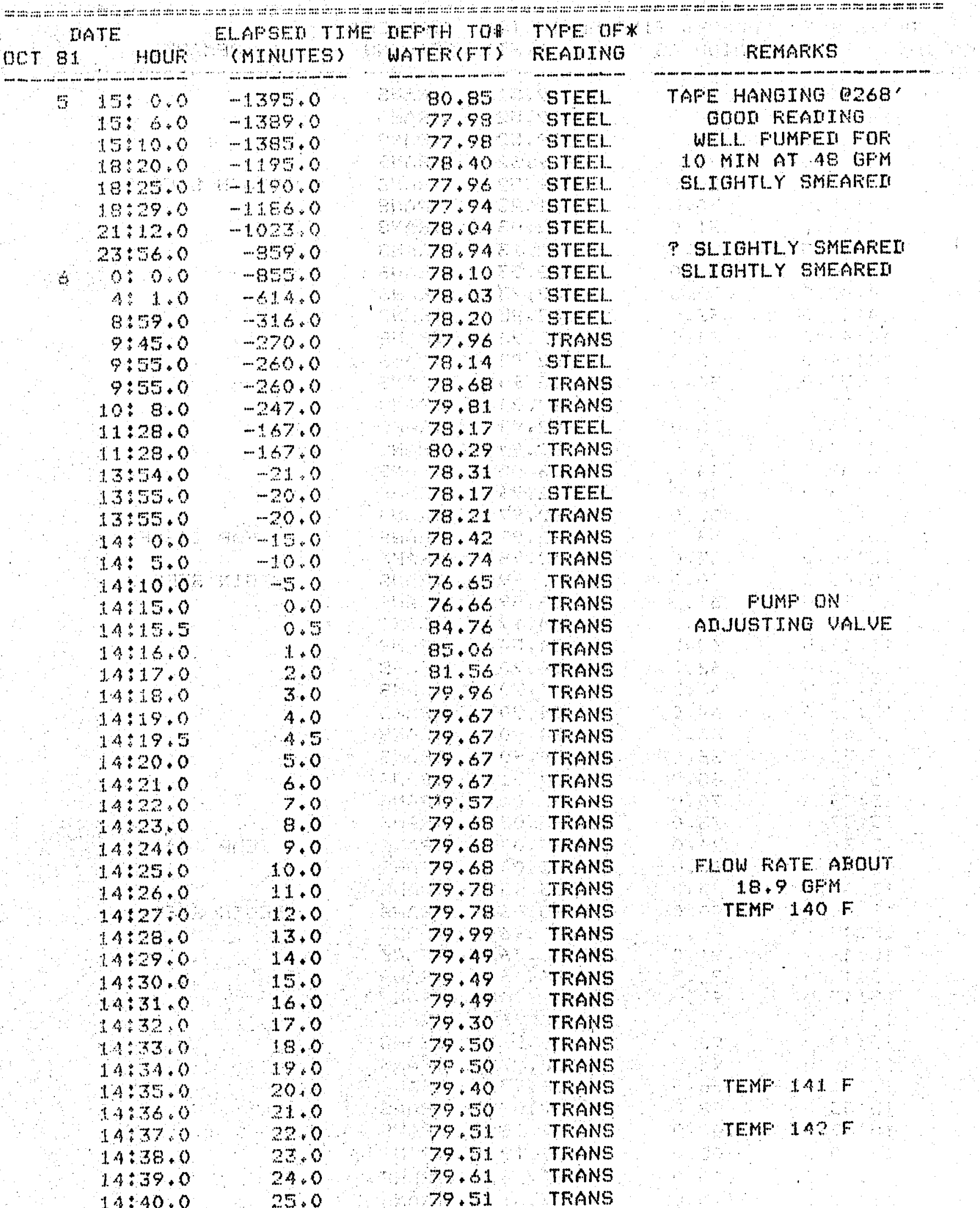


TABLE C-4 (continued)

Cambell et al, Na ser test - rerth to water computations

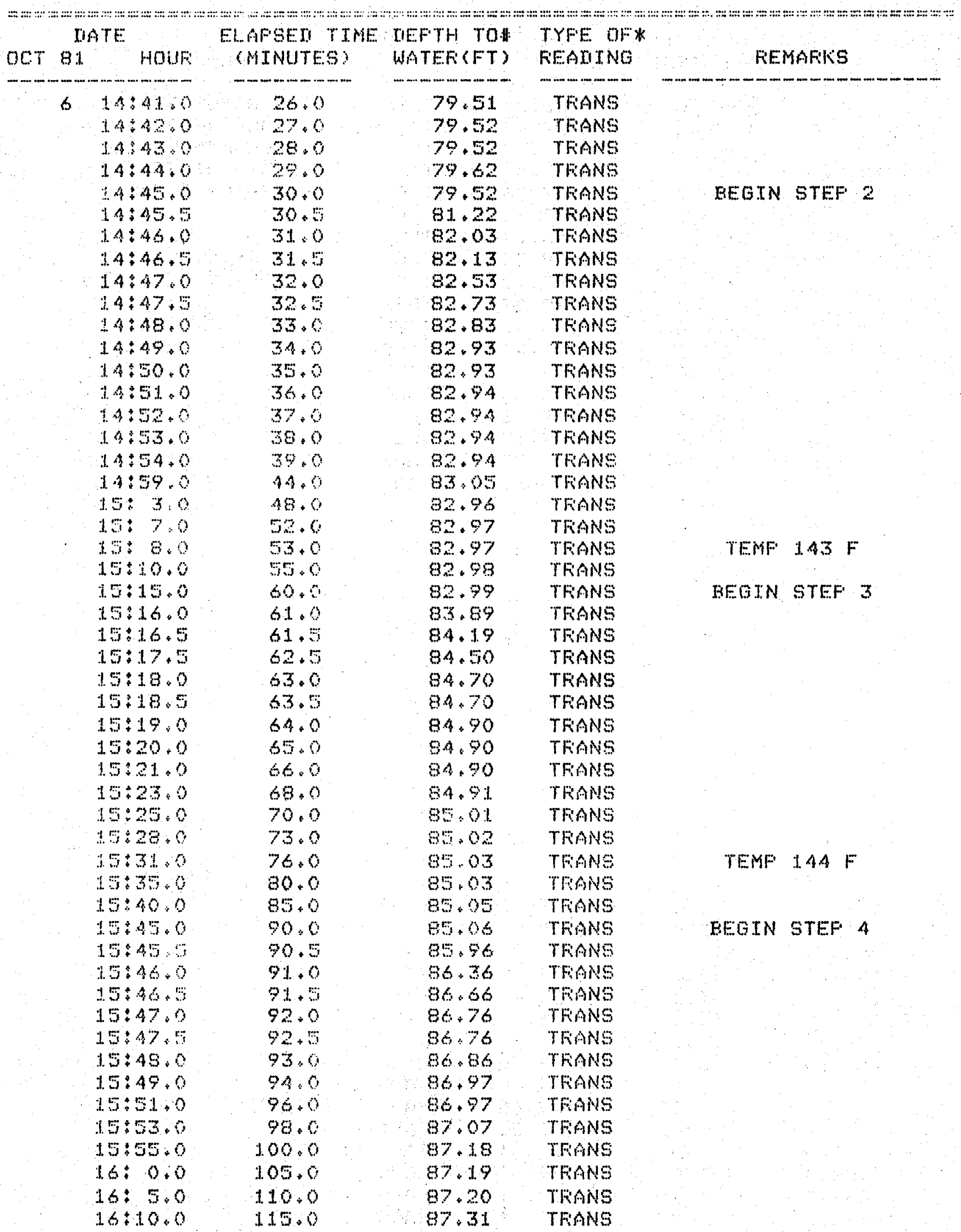


TABLE C-4 (continued)

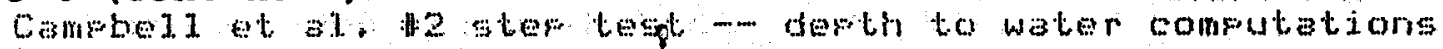

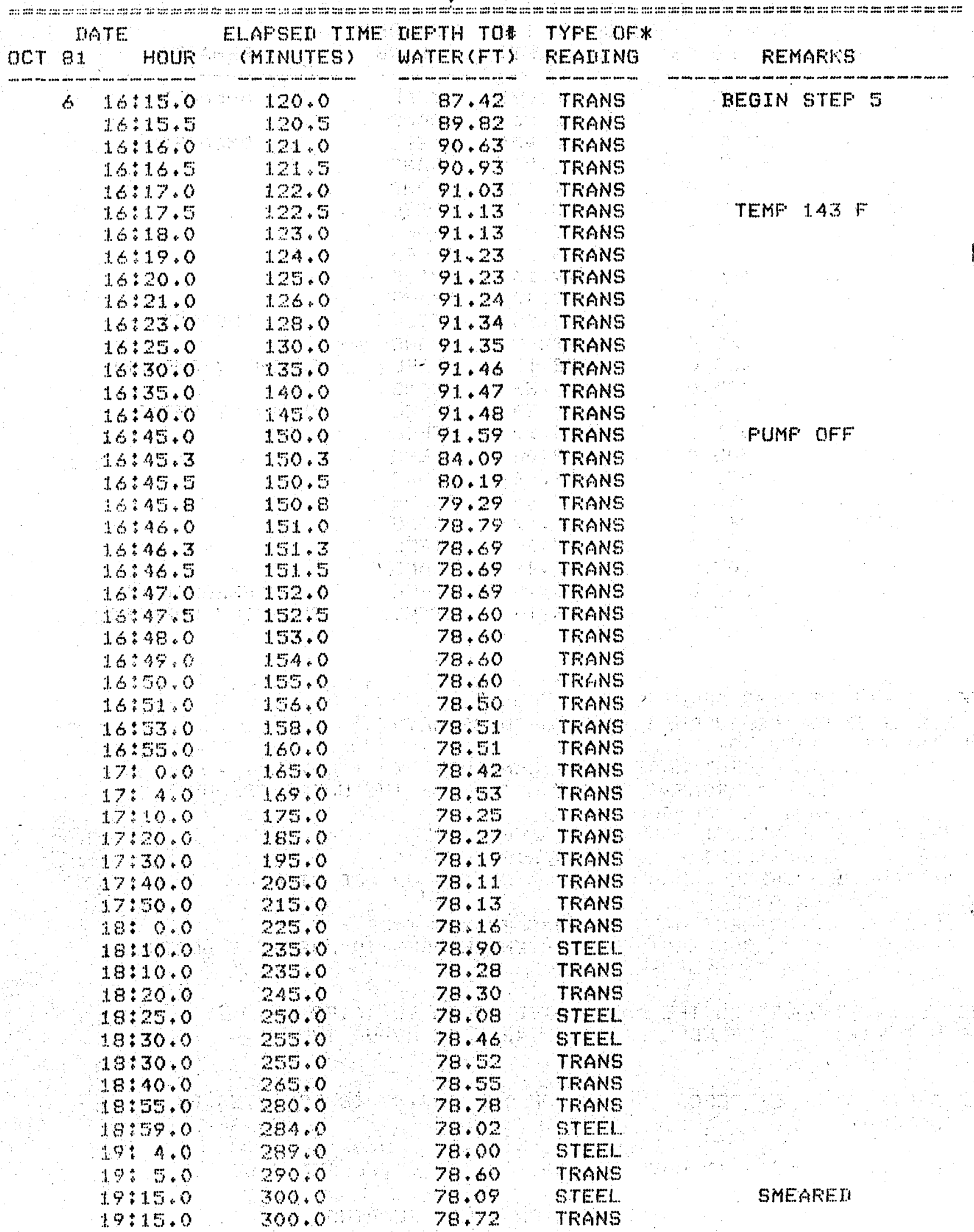


TABLE C-4. (continued)

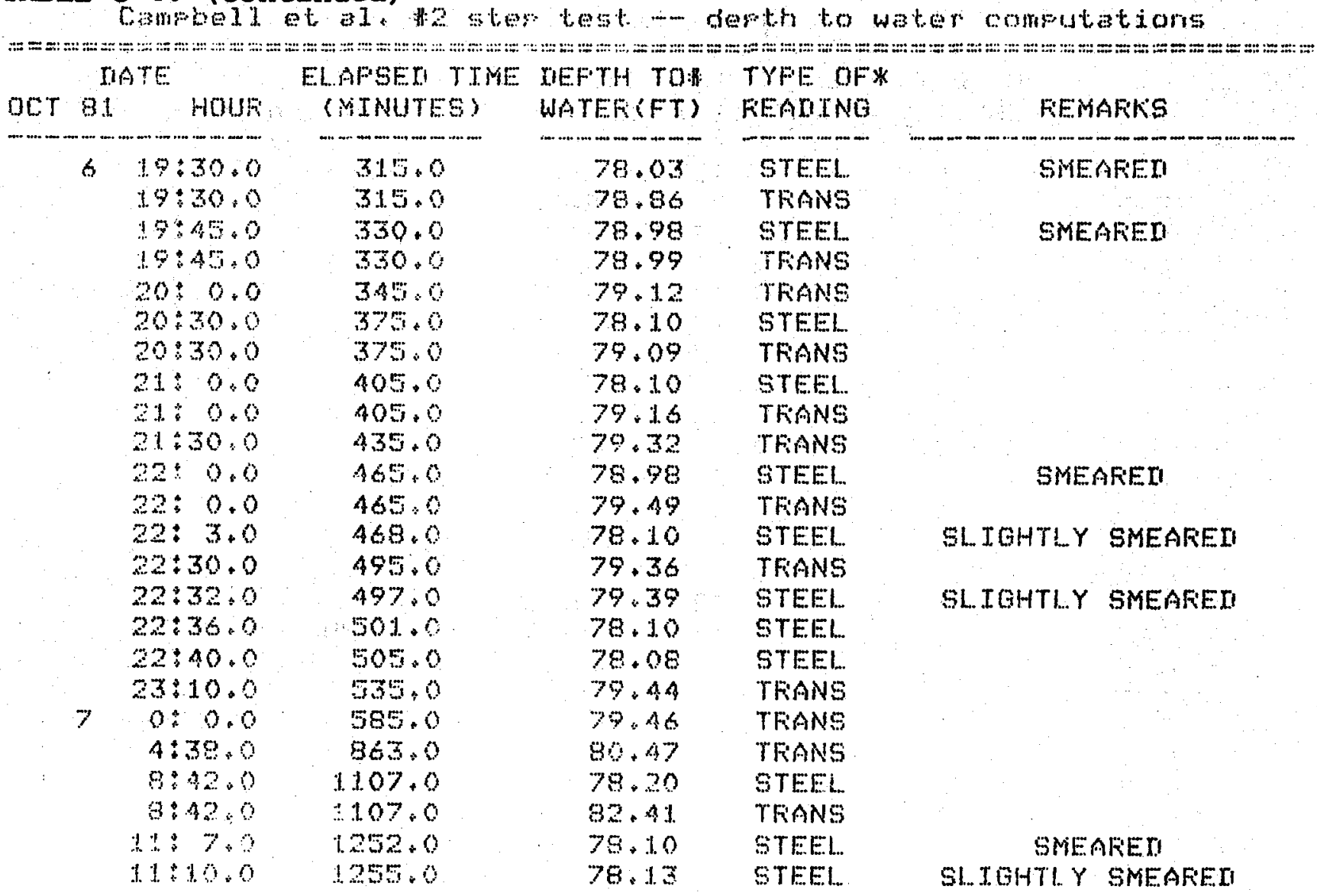

WTHE TYFE OF FEATINAS DENOTES THE TYFE OF

DEFTH TO WATER MEASUREMENT MATE. THESE MAY

IBE ANY OF THE FOLL OWTMS:

TFAMS:- MEASUFEMENT MANE BY A TFANSTUCER TN THE WELL.

THE MEASUFEMENT TS THE HETGHT OF THE WATER COLUMN AEOUE THE SENSOF.

STEEL YOASUEMENT MARE EY A STEEL TAFE.

ATK ME MUREMENT MARE EY AN ATHLTNE.

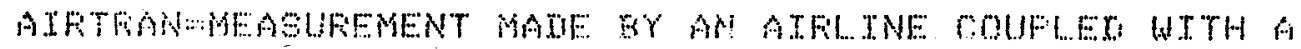
THASNUCER.

ELECT MA MUAEMENT MATE TY AN ELECTRIC TAFE.

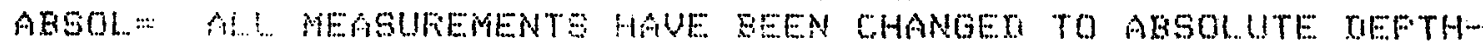
TCWDATEF MEASUREMENTS.

MTHE DEFTH TO WATEE IS THE CALCULATED REFTH TO WATEF

FFOM THE TOF OF THE WELL CASING, A3 FEET ABOUE THE

LAND SUFFACE.

THE DEFTH TO WATEF EELON THE TOF OF THE CASTNG TS COMEUTEN EY THE FORMULA,

FOF TRANS: TEFTH TO WATEF $16 \%$ - WATEF LEVEL REATTNG

FOF STEEL, REFTH TO WATEE :- WATER LEVEL FEARNO 
$\boldsymbol{P}$

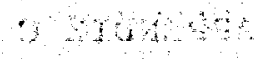

TABLE $\mathrm{C}-4$. (continued)

ELAFSEI TIME IS TAKEN FFOM TO AT 1415 ON $6-O C T$ - 81

FOR TRANS, DEPTH TO WATER $=(165-$ WATER LEVEL READING $)$

+0.00222 FT/MIN* (ELAPSED TIME-19.25)

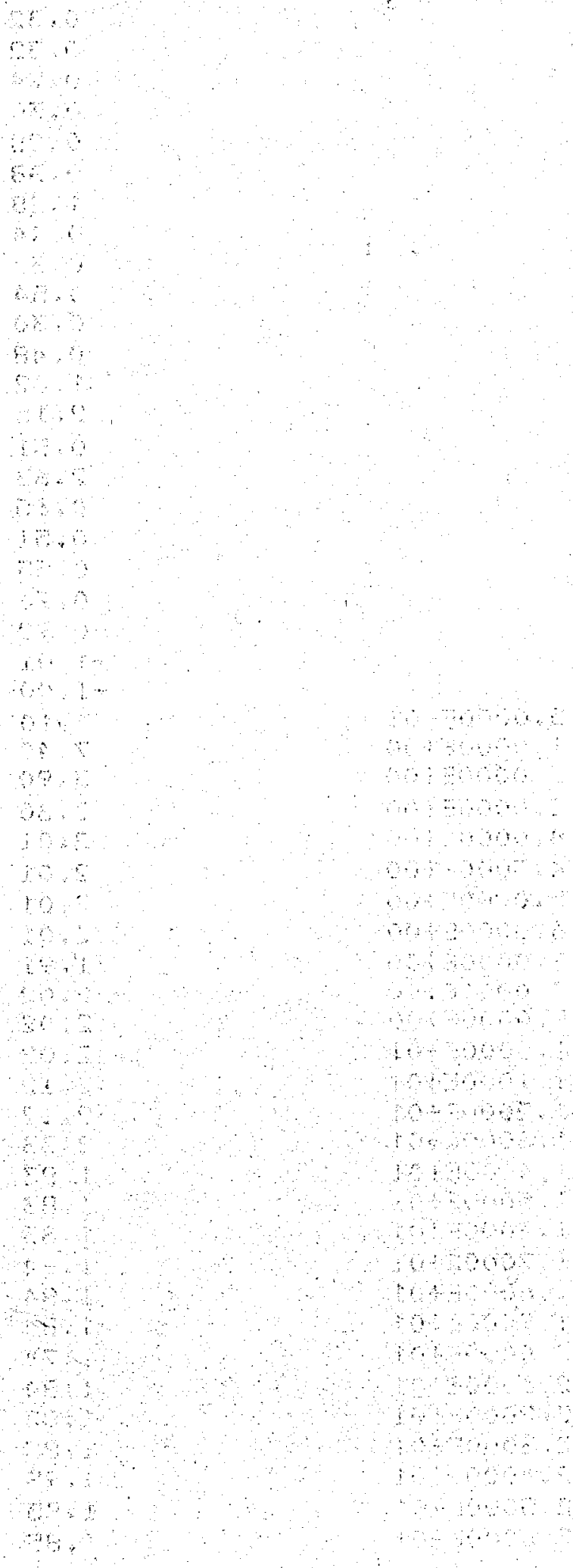




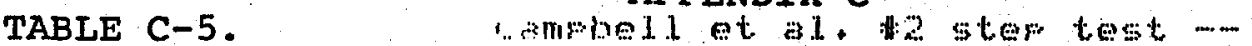

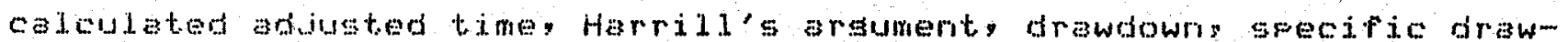
down (sta) and specific drawdown abjuted for Jacob's correction (sta)

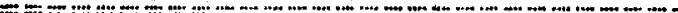

TIATE ELAFSEI

OCT BI HOUF TIME(MIN)

\section{$515 \% 60$}

$1.3 \div 10.0$

$18: 20 \cdot 0$

$18 \div 25+0$

$18 \div 29+0$

$21: 12.0$

$23: 56.0$

$6 \quad 0: 0.0$

$4: 1.0$

$8: 59.0$

$9: 45,0$

$9+5.50$

$9: 55+0$

$10: 8.0$

$11: 20.0$

$11: 28.0$

$13 \div 54.0$

$13 \div 55 \cdot 0$

1. $3+65+0$

$14: 0.0$

$14: 5.0$

$14: 10.0$

$16: 15.0$

$14: 15.5$

$14: 16,0$

$14: 17 \div 0$

$14: 18.0$

$14: 19.0$

$14: 19.5$

$14 \div 20.0$

$14 \div 21.0$

1.4:22.0

$14: 23+0$

$14: 24,0$

$14: 25 \cdot 0$

$14: 26+0$

$14: 27.0$

$14: 28+0$

$14: 29.0$

$14: 30.0$

$14: 31.0$

$14: 32+0$

$14: 33.0$

$14: 34.0$

$14: 3: 0$

$1.4: 36: 0$

$14: 37.0$

$14 \div 38.0$

$14: 37+0$

$14: 40 \div 0$

$14: 41.0$

\section{TIME}

\section{A}

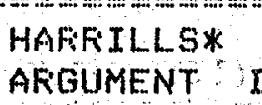

IIFi
IOW

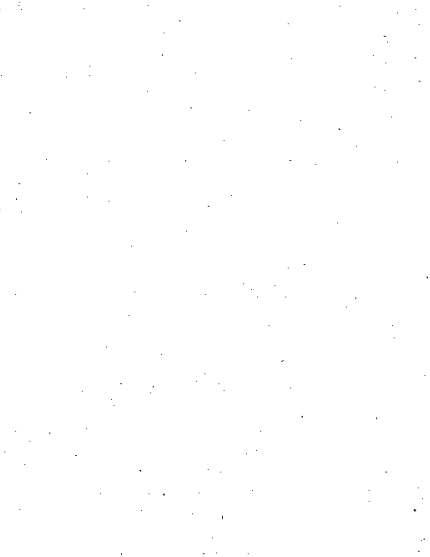

$0.5 \quad 5.0000 E-01$

$1.0 \quad 1,0000 E+00$

$2.0 \quad 2.0000 E+00$

$3.0 \quad 3.0000 E+00$

$4.0 \quad 4.0000 E+00$

$4+5$ A.5000E+00

$3.0 \quad 5.0000 E+00$

$6.06 .0000 \mathrm{E}+00$

$7.0 .7 .0000 \mathrm{E}+00$

$8.0 \quad 8.0000 E+00$

$9.09 .0000 \mathrm{E}+00$

10.0 1.0000E+01.

1.1.0 1. $1000 \mathrm{E}+0 \mathrm{i}$

12.0 1.2000E+01

$13.0 \quad 1+3000 E+01$

$14.0 \quad 1.4000 E+01$

$15,0: 1.5000 E+01$

$16+0$ 1.6000E+01

$17.0 \quad 1.7000 E+01$

$18.0 \quad 1.8000 E+01$

$17.0 \quad 1.9000 E+01$

20.0 2.0000E+01

21.0 2. $1000 E+01$

$22+0 \quad 2.2000 E+01$

$23.02 .3000 \mathrm{E}+01$

24.0 2. $4000 E+01$

25,0 2.5000E+01

$26.0: 2.6000 \mathrm{E}+01$
0.32

0.32

0.74

0.30

0.28

0.38

1.28

0.44

0.37

0.54

0.30

0.48

1.02

2.15

0.51

2.63

0.65

0.51

0.55

0.76

$-0.92$

$-1.01$

$-1.00$

7.10

7.40

3.90

2.30

2.01

2.01

2.01

2.01

1.91

2.02

2.02

2.02

2.12

2.12

2.33

1.83

1.83

1.83

1.64

1.84

1.84

1.74

1. 84

1.85

1.85

1.95

1.85

1.85 $s / 0$

(FT/GPM)

$S / R$

$\begin{array}{ll}0.406 & 0.398 \\ 0.423 & 0.414 \\ 0.223 & 0.220 \\ 0.131 & 0.131 \\ 0.115 & 0.114 \\ 0.115 & 0.114 \\ 0.115 & 0.114 \\ 0.115 & 0.114 \\ 0.109 & 0.109 \\ 0.115 & 0.115 \\ 0.115 & 0.115 \\ 0.115 & 0.115 \\ 0.121 & 0.120 \\ 0.121 & 0.120 \\ 0.133 & 0.132 \\ 0.105 & 0.104 \\ 0.105 & 0.104 \\ 0.105 & 0.104 \\ 0.094 & 0.093 \\ 0.105 & 0.105 \\ 0.105 & 0.105 \\ 0.099 & 0.099 \\ 0.105 & 0.105 \\ 0.106 & 0.105 \\ 0.106 & 0.105 \\ 0.111 & 0.111 \\ 0.106 & 0.105 \\ 0.106 & 0.105 \\ & \end{array}$


TABLE C-5. (continued) Cambe11 et al. \#2 step test calculated adubled dime Harrial's argument, drawbowri, sfecific draw

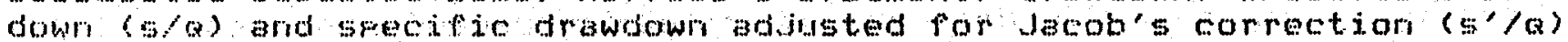

\begin{tabular}{|c|c|c|c|c|c|c|c|}
\hline \multirow[t]{2}{*}{$\mathrm{OCT}$} & MATE & ELAFSEO & GRDJUSTERK* & $\begin{array}{l}\text { HAFFIILLS } \\
\text { AFGUMENT }\end{array}$ & $\begin{array}{l}\text { IFAW- } \\
\text { RIOWN (FT) }\end{array}$ & $\begin{array}{c}S / Q \\
(F T / Q F M)\end{array}$ & $5^{\prime} / 10: k$ \\
\hline & & & & & & & \\
\hline 6 & $\begin{array}{l}14: 42,0 \\
14: 43,0\end{array}$ & $\begin{array}{r}27.0 \\
28.0\end{array}$ & $\begin{array}{l}2.7000 E+01 \\
2.8000 E+01\end{array}$ & & $\begin{array}{l}1.86 \\
1.86\end{array}$ & $\begin{array}{l}0.106 \\
0.106\end{array}$ & $\begin{array}{l}0.106 \\
0.106\end{array}$ \\
\hline & $14+A A \div 0$ & $\begin{array}{r}29.0 \\
29.0\end{array}$ & $2.9000 E+01$ & & $\begin{array}{l}1.00 \\
1.96\end{array}$ & 0.112 & 0.111 \\
\hline & $14: 45,0$ & $\therefore 30.0$ & $3.0000 E+01$ & & 1.86 & 0.106 & 0.106 \\
\hline & $14: 45.5$ & 30.5 & $5.5449 E+00$ & & 3.56 & 0.119 & 0.118 \\
\hline & $14: 46,0$ & 31.0 & $7.4623 E+00$ & & 4.37 & 0.146 & 0.144 \\
\hline & $14: 46.5$ & $31+5$ & $8.911 \mathrm{BE}+00$ & & 4.47 & 0.149 & 0.148 \\
\hline & $14 \div 47.0$ & $32+0$ & $1.0134 E+01$ & & 4.87 & 0.163. & 0.161 \\
\hline & $14: 47.5$ & 32.5 & $1.1218 E+01$ & & 5.07 & 0.170 & 0.167 \\
\hline & $14: 48.0$ & 33.0 & $1+2008 E+01$ & & 5.17 & 0.173 & 0.170 \\
\hline & $14: 49.0$ & 34.0 & $1.3997 E+01$ & & 5.27 & 0.176 & 0.174 \\
\hline & 14850.0 & 35.0 & $1,561>E+01$ & & 5.27 & 0.176 & 0.174 \\
\hline & $14 \div 51,0$ & 36.0 & $1+7123 E+01$ & & $5+28$ & 0.177 & 0.174 \\
\hline & $14: 52.0$ & 37.0 & 1. $8549 E+01$ & & 5.28 & 0.177 & 0.174 \\
\hline & $14: 53,0$ & 38.0 & $1.9914 E+01$ & & 5.28 & 0.1 .77 & 0.174 \\
\hline & $14: 54.0$ & 39.0 & $2,1231 E+01$ & & 5.28 & 0.177 & 0.174 \\
\hline & $14: 59.0$ & 44.0 & $2.7366 E+01$ & & 5.39 & 0.180 & 0.178 \\
\hline & $15: 3.0$ & 48,0 & $3+1958 E+01$ & & 5.30 & 0.1 .77 & 0.175 \\
\hline & $15: 7.0$ & 52.0 & $3.6398 E+01$ & & 5.31 & 0.178 & 0.178 \\
\hline & $15: 8.0$ & 53.0 & $3.7491 E+01$ & & 5.31 & 0.178 & 0.175 \\
\hline & $15: 10.0$ & 58.0 & $3.9660 E+01$ & & 5.32 & 0.178 & 0.175 \\
\hline & $15: 15.0$ & 60.0 & $4.5010 E+01$ & & 5.33 & 0.178 & 0.176 \\
\hline & $15: 16,0$ & 61.0 & $2,1506 E+01$ & & 6.23 & 0.174 & 0.171 \\
\hline & $15: 16,5$ & 61.5 & $2.6451 E+01$ & & 6.53 & 0.182 & 0.179 \\
\hline & $15: 17.5$ & 62.7 & $2.9317 E+01$ & & 6.84 & 0.191 & 0.187 \\
\hline & $15 \div 18.0$ & 63.0 & $3.0490 E+01$ & & 7.04 & 0.197 & 0.193 \\
\hline & $15: 18.5$ & 63.6 & 3.156 & & 7.04 & 0.197 & 0.193 \\
\hline & $15: 15.0$ & 64.0 & $3.2553 E+01$ & & 7.24 & 0.202 & 0.198 \\
\hline & $15 \div 20+0$ & 65.0 & $3.4372 E+01$ & & 7.24 & 0.202 & 0.1 .98 \\
\hline & $15: 21.0$ & 66.0 & $3.6036 E+01$ & & 7.24 & 0.202 & 0.198 \\
\hline & $15: 23.0$ & $68+0$ & $3,9066 E+01$ & & 7.25 & 0.203 & 0.198 \\
\hline & $15: 25.0$ & 70.0 & $4.1845 E+01$ & & 7.35 & 0.205 & 01 \\
\hline & $15: 28.0$ & 973.0 & $4.5731 E+01$ & & 7.36 & 0.206 & 0.201 \\
\hline & $15 \div 31.0$ & .0 & 4.940 & & 7 & 0.206 & 02 \\
\hline & $15 \div 35.0$ & 80.0 & 5.4096 & & 7.37 & 0.206 & 0.202 \\
\hline & $15: 40.0$ & $85+0$ & 5.975 & & 7.39 & 0.206 & 0.202 \\
\hline & $15: 45.0$ & 90.0 & $6.5256 E+01$ & & 7.40 & 0.207 & 0.202 \\
\hline & $15: 45 \cdot 5:$ & 90.5 & $3.4356 E+01$ & & 8.30 & 0.201 & 0.196 \\
\hline & $15: 46.0$ & 91.0 & $3.7948 E+01$ & & 8.70 & 0.211 & 0.206 \\
\hline & $15: 46.5$ & 91,5 & $4.0337 E+01$ & & 9.00 & 0.218 & 0.212 \\
\hline & $15: 47,0$ & 92.0 & $4+2206 E+01$ & & 9.10 & 0.220 & 0.21 .5 \\
\hline & $15: 47.5$ & 92.5 & $4.3781 E+01$ & & $9+10$ & 0.220 & 0 \\
\hline & $15: 48.0$ & 93.0 & $4.5166 E+01$ & & 9.20 & 0.223 & 0.217 \\
\hline & $15: 49.0$ & 94.0 & 4.7569 & & & 0.225 & 0. \\
\hline & $15: 51.0$ & 96.0 & $5.1547 E+01$ & $\cdots$ & 9.31 & 0.225 & 0.220 \\
\hline & $15: 53.0$ & 98.0 & $5.4940 E+01$ & & 9.41 & 0.228 & 0.222 \\
\hline & $15: 55.0$ & 100.0 & $5.8006 \mathrm{E}+01$ & & 9.52 & 0.231 & 0.224 \\
\hline & $16: 0.0$ & 105.0 & $6.4894 E+01$ & & 9.53 & 0.231 & 0.225 \\
\hline & $16: 5.0$ & 110.0 & $7.1180 E+01$ & & 9.54 & 0.231 & 0.225 \\
\hline & $16: 10.0$ & 115.0 & $7.7136 \mathrm{E}+01$ & & 9.65 & 0.234 & 0.227 \\
\hline & $16: 15.0$ & 120.0 & $8.2887 E+01$ & 4 & 9.76 & 0.236 & 0.230 \\
\hline
\end{tabular}


RABLE C-5. (continued) Camboll et $31+22$ tep test calculated adjusted time Harrill's arsument, drawdown, soecific drawdown $\left(s / Q\right.$ ) and specific drawdown adjusted for Jacob's correction ( $s^{\prime} /(a)$

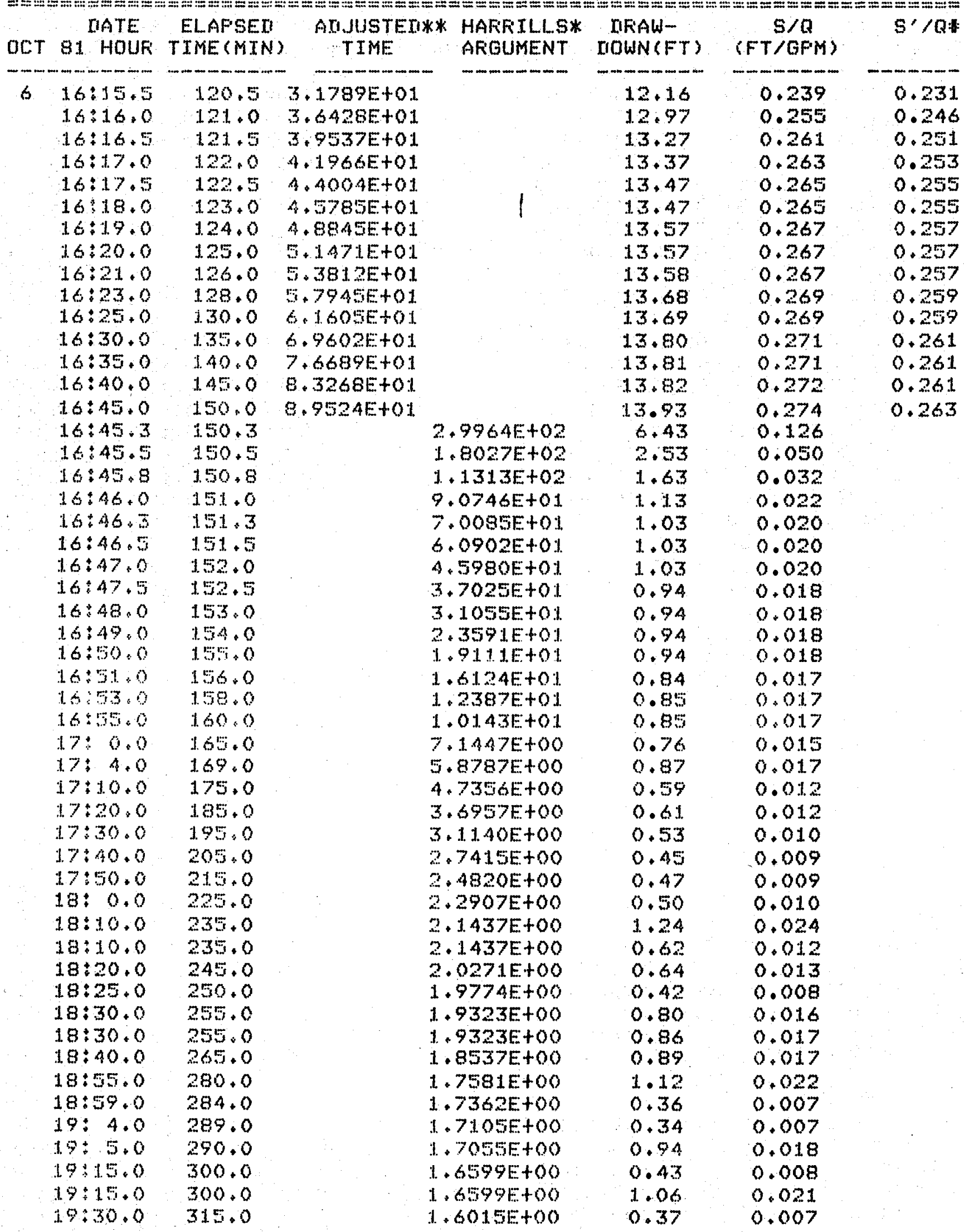


TABLE C-5. (continued) campoll at a 1 क 2 btomtest calculated adusted time Harrild"s arstumerit, drawdowny specific draw-

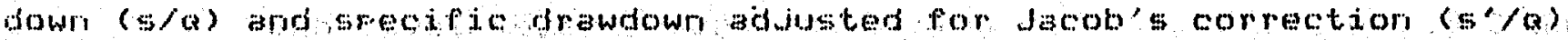

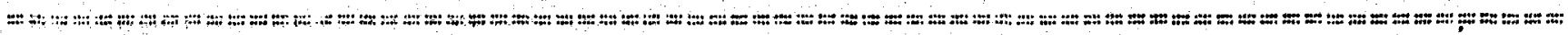

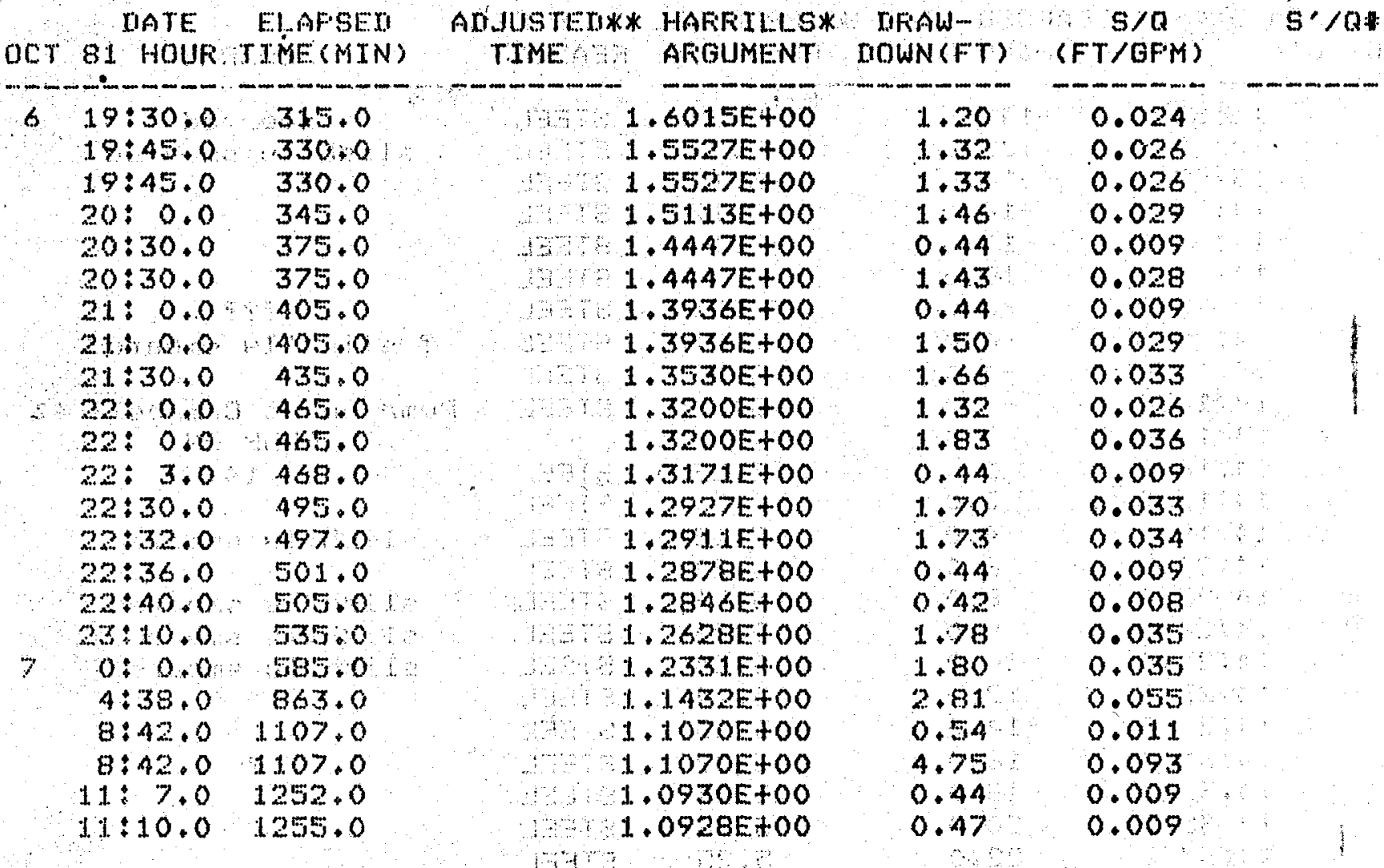

WHAFETLL, J. R, 1971, DETERMTNING TFANSMISSIUITY FFOM WATEFI-LEVEL. FECOUERY OF A STEP-DFAWDOWN TEST U. S . GEOL. SURU, FROF. FAFEF $700-C, F+C 212-213$

* *ATJUSTED TTME, A GENEFAL TZEI HARFILL'S ARGUMENT,

HTFSOY, $Y, K$, SUMMEFS, W, K, 1980, IIETERMINATION OF ARUTFER FAFAMETERS FROM STEF TESTS ANI INTERMITTENT FUMFING IIATA G GOUNI WATEF, VI8, 2 FF137-146.

HS IS THE JACOE CORFECT TON, $S=5-5 * 2 / 20$.

THE IRAUIOWN S AT EILAGEI TIME T TS CALCULATEI FROM THE ERUATION:

$S=$ (OBSEFUEII IEPTH TO WATEF AT TIME T)-

(TFENDITNTTIAL DEFTH TO WATER)

WHEFE TFENI 0 * ELAFSED TIME.

THE LENGTH OF THE CONTEIRITTING INTEFUAL OF THE WELL IS 190 FEET.

THE IEFTH FFOM THE TOF OF CASING TO THE SCFEEN IS 77 FEET. 
APPENDIX C

ABLE C-6. North obervation wel 1 step test-water level data

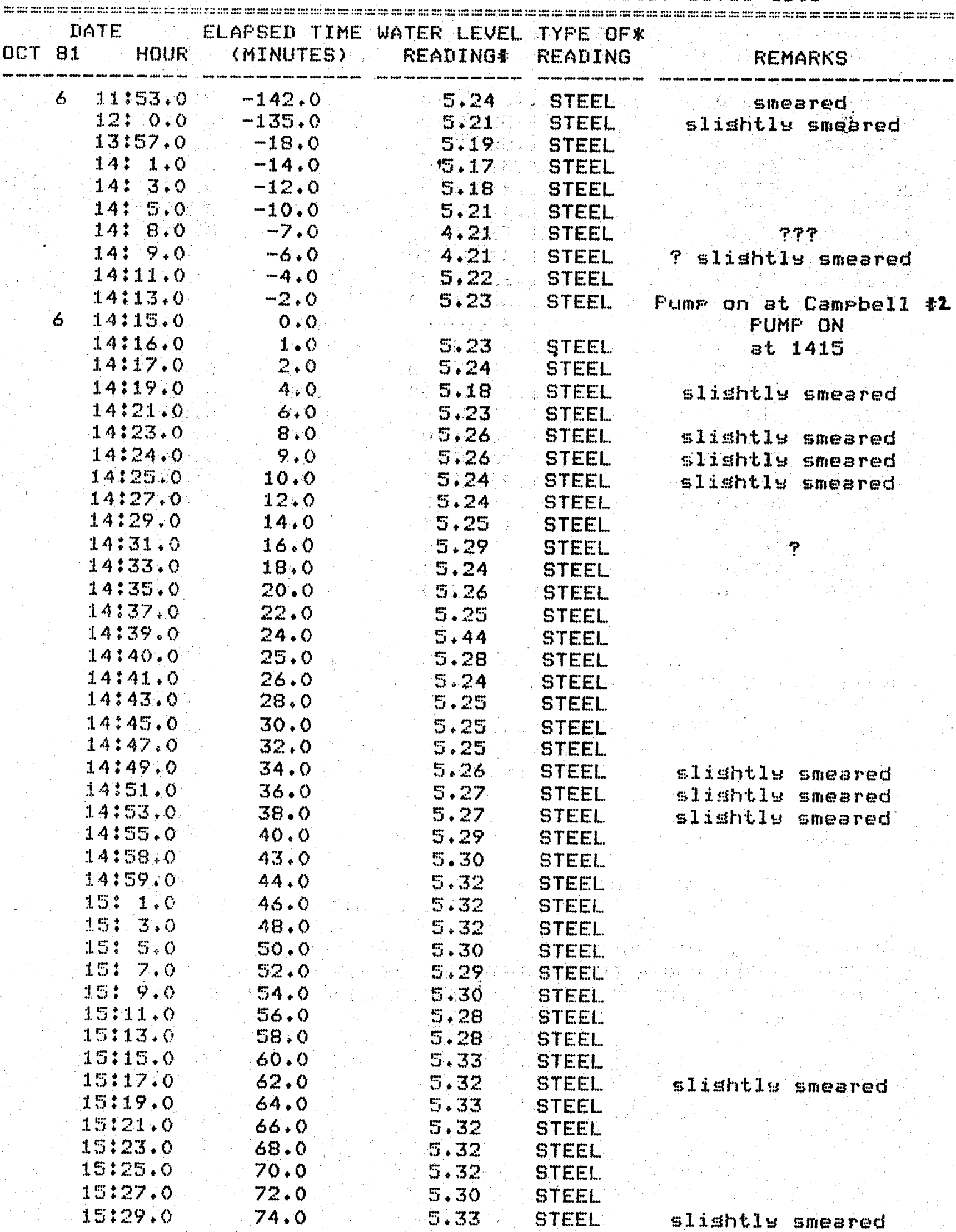


TABLE C-6. (continued)

North observation wel ster test - water lovel data

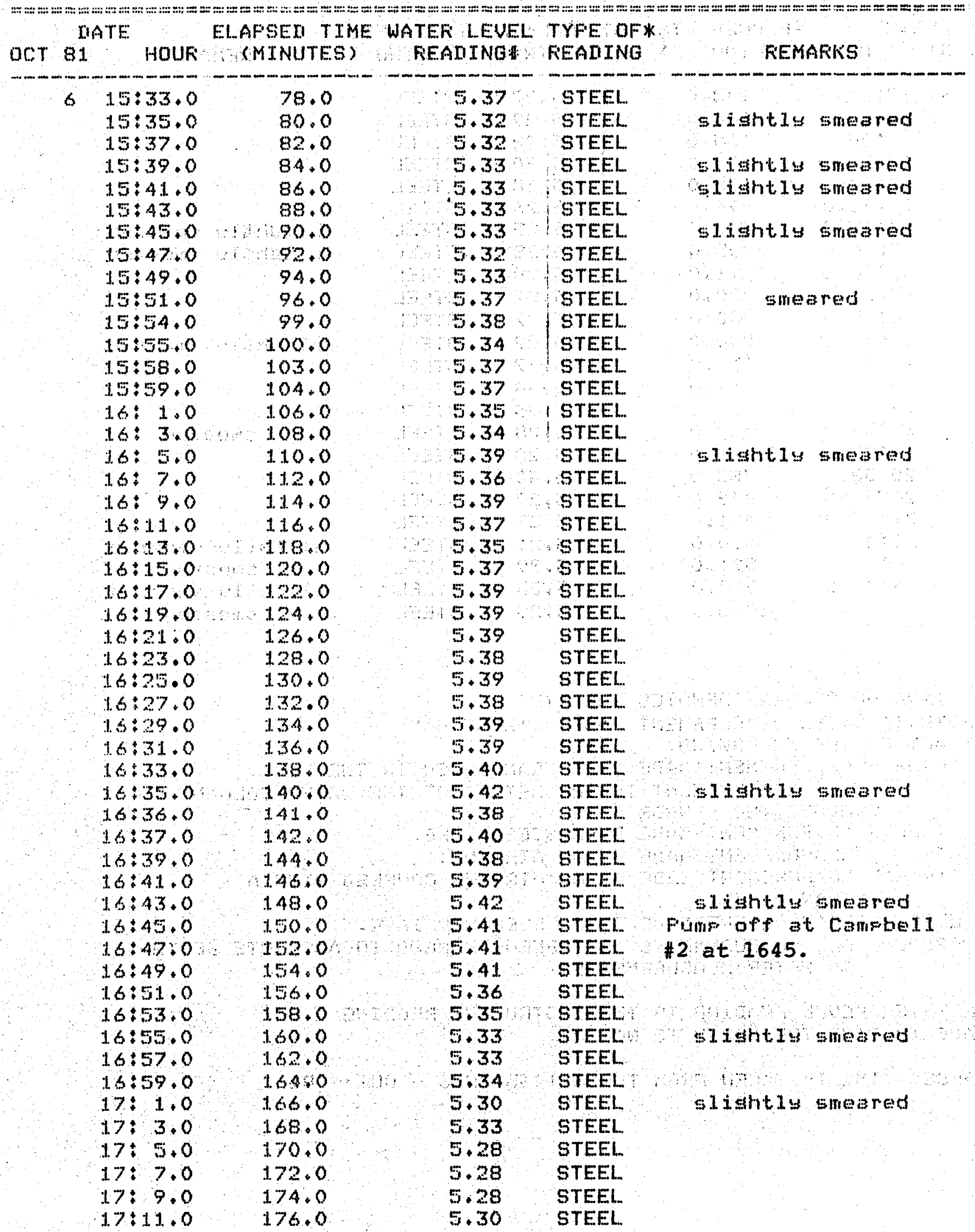


TABLE C-6 (continued)

North observation well step test - water level data

\begin{tabular}{|c|c|c|c|c|c|c|}
\hline OCT & 81 & ATE HOUS & $\begin{array}{c}\text { ELAFSEO TTME } \\
\text { (MINUTES) }\end{array}$ & $\begin{array}{l}\text { WATEF LEVEL } \\
\text { FEATING }\end{array}$ & $\begin{array}{l}\text { TYFE OF* } \\
\text { FEAIING }\end{array}$ & FEMAFKS \\
\hline , & 7 & $\begin{array}{l}17: 13.0 \\
17: 15.0 \\
17: 20.0 \\
17: 25.0 \\
17: 30.0 \\
17: 31.0 \\
17: 35.0 \\
17: 40.0 \\
17: 46.0 \\
17: 55.0 \\
18: 5.0 \\
18: 15.0 \\
18: 29.0 \\
18: 44.0 \\
18: 58.0 \\
19: 37.0 \\
19: 59.0 \\
20: 38.0 \\
21: 44.0 \\
21: 46.0 \\
22: 45.0 \\
0: 6.0 \\
4: 32.0 \\
8: 30.0\end{array}$ & $\begin{array}{r}178.0 \\
180.0 \\
185.0 \\
190.0 \\
195.0 \\
196.0 \\
200.0 \\
205.0 \\
211.0 \\
220.0 \\
230.0 \\
240.0 \\
254.0 \\
269.0 \\
283.0 \\
322.0 \\
344.0 \\
383.0 \\
449.0 \\
451.0 \\
510.0 \\
591.0 \\
857.0 \\
1095.0\end{array}$ & $\begin{array}{l}5.27 \\
5.29 \\
5.28 \\
5.30 \\
5.38 \\
5.26 \\
5.25 \\
5.28 \\
5.28 \\
5.27 \\
5.27 \\
5.22 \\
5.27 \\
5.30 \\
5.25 \\
5.28 \\
5.28 \\
5.40 \\
5.29 \\
5.27 \\
5.26 \\
5.29 \\
5.28 \\
5.25\end{array}$ & $\begin{array}{l}\text { STEEL } \\
\text { STEEL } \\
\text { STEEL. } \\
\text { STEEL } \\
\text { STEEL } \\
\text { STEEL } \\
\text { STEEL } \\
\text { STEEL. } \\
\text { STEEL. } \\
\text { STEEL. } \\
\text { STEEL. } \\
\text { STEEL. } \\
\text { STEEL. } \\
\text { STEEL.. } \\
\text { STEEL. } \\
\text { STEEL.. } \\
\text { STEEL. } \\
\text { STEEL } \\
\text { STEEL } \\
\text { STEEL. } \\
\text { STEEL } \\
\text { STEEL. } \\
\text { STEEL. } \\
\text { STEEL. }\end{array}$ & $\begin{array}{l}\text { siluntly smeared } \\
\text { sidshtly smeared } \\
\text { siisht } 1 \text { smeared }\end{array}$ \\
\hline
\end{tabular}

*THE TYFE OF FEAIING DENOTES THE TYFE OF

DEFTH TO WATEF MEASUREMENT MAIE. THESE MAY

BE ANY OF THE FOLLOWING:

TRANS:- MEASUREMENT MAIE BY A TRANSIUCEF IN THE WELL. THE MEASUFEMENT IS THE HEIGHT OF THE WATEF COLUMN AROUE THE SENSOR.

STEEL :-: MEASUREMENT MALE EY A STEEL TAFE.

ATR $=$ MEASUREMENT MAIEE EY GN AIFLTNE.

AIFTFAN=MEASUREMENT MAIE EY AN AIFLINE COUFLEI WITH A TFANSRUCEF.

ELECT = MEASUFEMENT MADE BY AN ELECTRIC TAFE.

AESOL = ALL. MEASUFEMENTS HAUE EEEN CHANGEO TO ABSOLUTE IEFTHTO-WATER MEASUREMENTS.

\#THE WATER LEUEL REAITNG TS THE INSTRUMENT FEAIING

MAIE TO FINI THE IIEFTH TO WATER.

ELAFSEI TIME IS TAKEN FROM TO AT 1415 ON $6-$ OCT - 81 


\section{APPENDIX C}

TABLE C-7.

North observation we1l sterost-besth to water computations

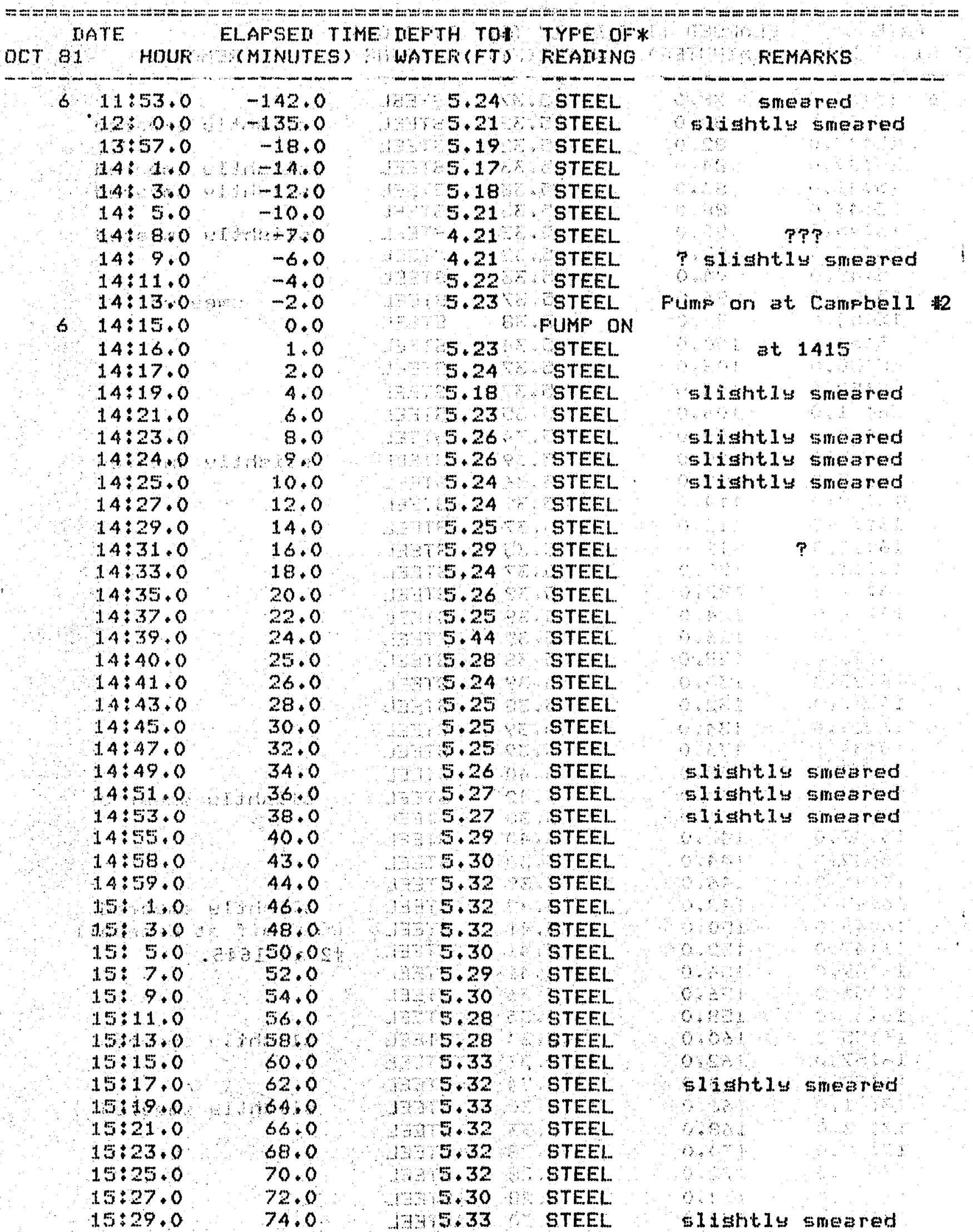


TABLE C-7. (continued)

North observetion we11 ster test-opth to water computations

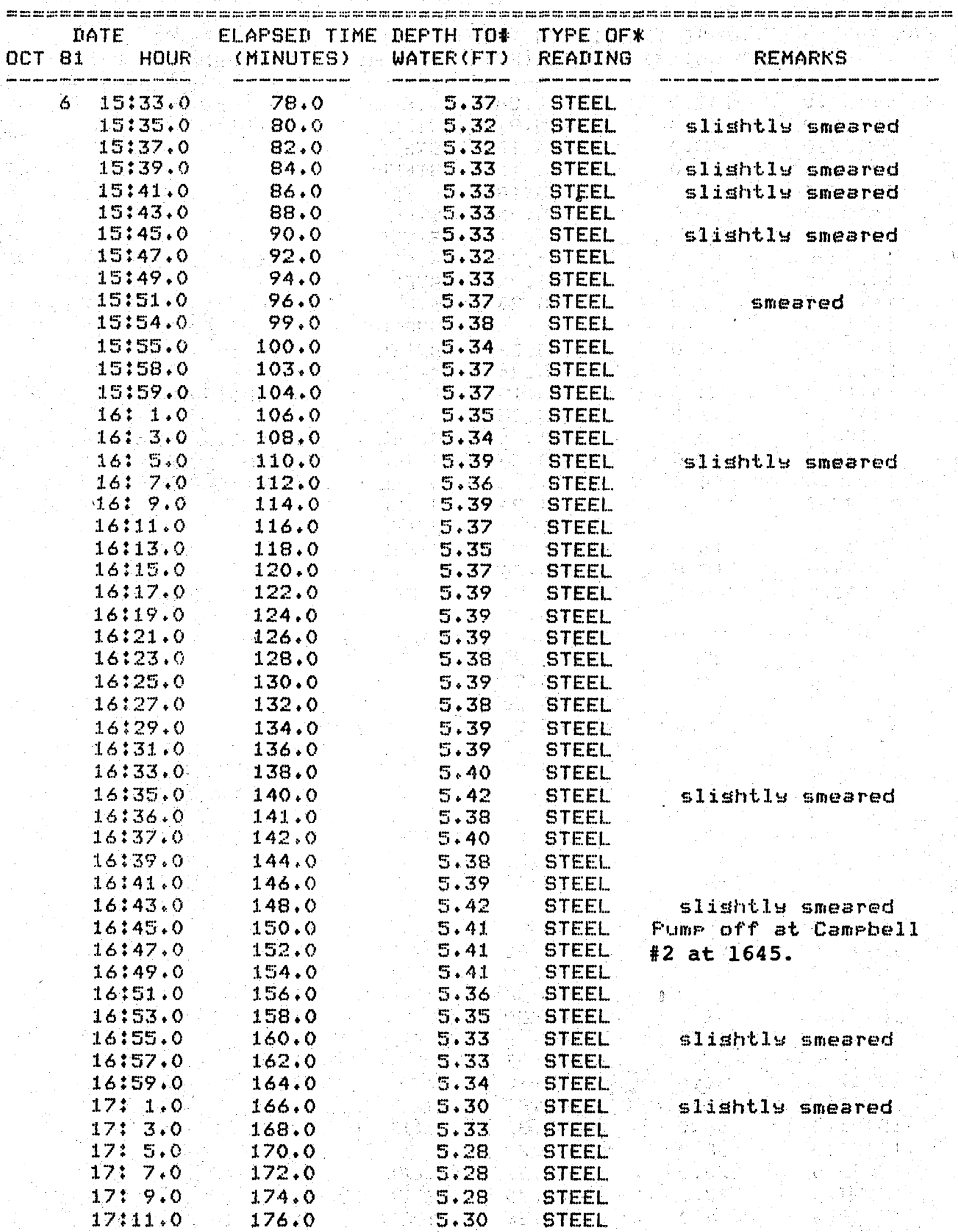


TABLE C-7. (continued)

North buservation tuel l steptest - - derth to water computations

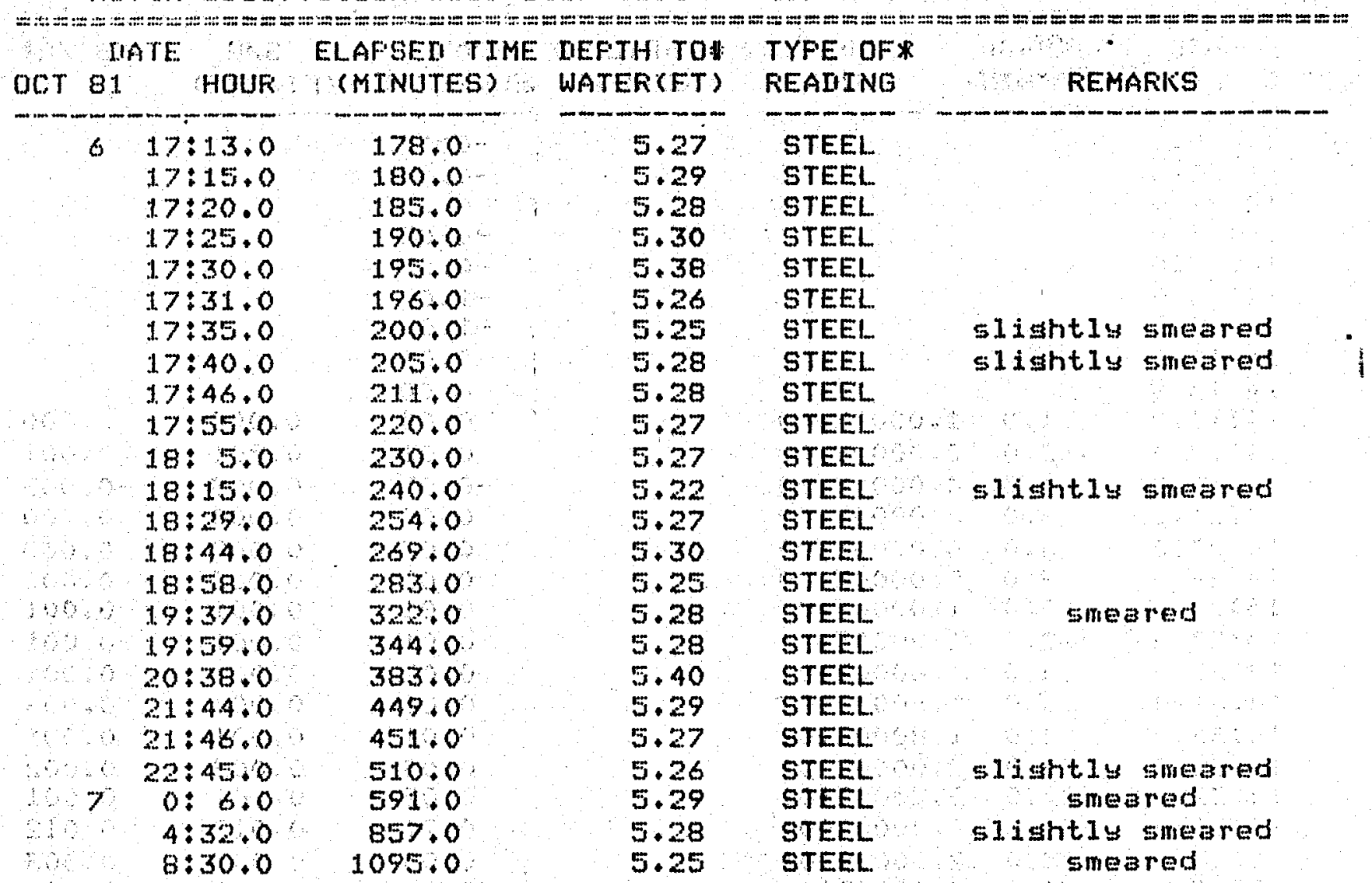

*THE TYPE OF REAIING DENOTES THE TYFE OF

DEFTH TO WATEF MEASUREMENT MADE. THESE MAY

DE ANY OF THE FOLLOWTNG:

TRANS:- MEASUFEMENT MAIIE EY A TFANSIUCEF IN THE WELL.

THE MEASUREMENT IS THE HEIGHT OF THE WATER COLUMN AROOE THE SENSOR.

STEEL = MEASUFEMENT MANE EY A STEEL TAFE.

ATR $=$ MEASUFEMENT MALE BY AN AIRLINE.

ATFTFANEMEASUFEMENT MADE EY AN AIFLINE COUFLEU WITH A

G TFANSRUCEF,

ELECT = MEASUREMENT MADE BY AN ELECTRIC TAFE.

ABSOL = ALL MEASUREMENTS HAUE BEEN CHANGED TO AESOLUTE IIEFTHTO-WATER MEASUREMENTS.

\#THE IEPTH TO WATER IS THE CALCULATEN DIEFTH TO WATER

FFOM THE TOF OF THE WELL CASTNG, 35 FEET ABOVE THE

LAND SURFACE.

THE INEFTH TO WATER EELOW THE TOF OF THE CASING IS COMFUTEI EY

THE FORMULA, 2,

FOR STEEL, IIEFTH TO WATER = WATER LEVEL REATING

ELAFSEN TIME IS TAKEN FFOM TO AT 1415 ON $6-O C T-81$ 


\section{APPENDIX C}

TABLE C-8, North observation well ster test calculated adjusted time, Harriil's argument, drawdown, sfecific draw down $(s / Q)$ and specific drawdown adjusted for Jacob's correction $(s / Q)$

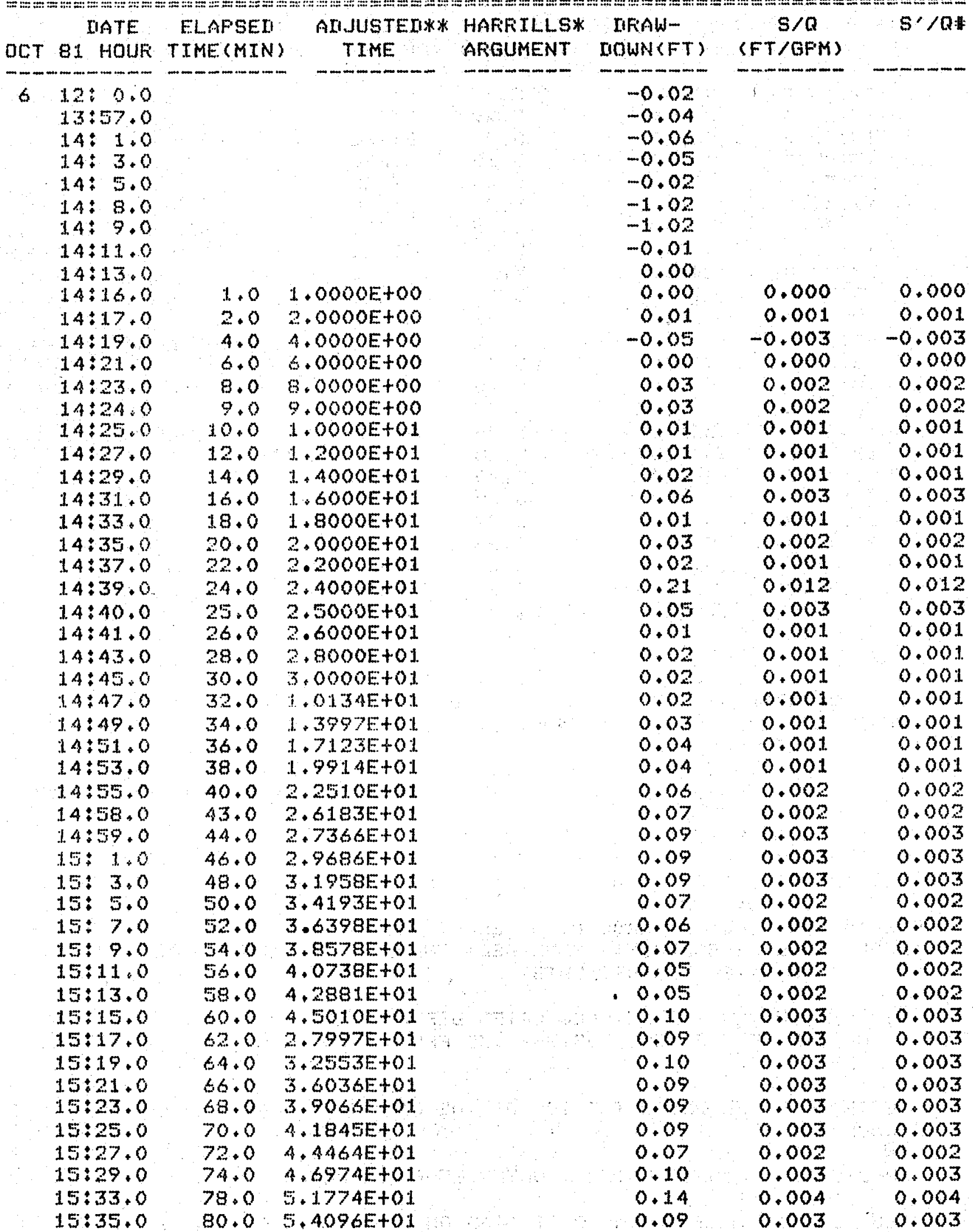


TABLE C-8. (continued) North observation wel stef test calculated adjusted time, Harri1.'s bratument, drawbown, sweipic draw-

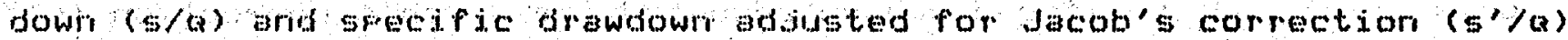

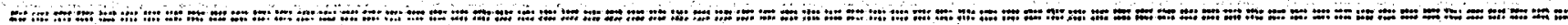

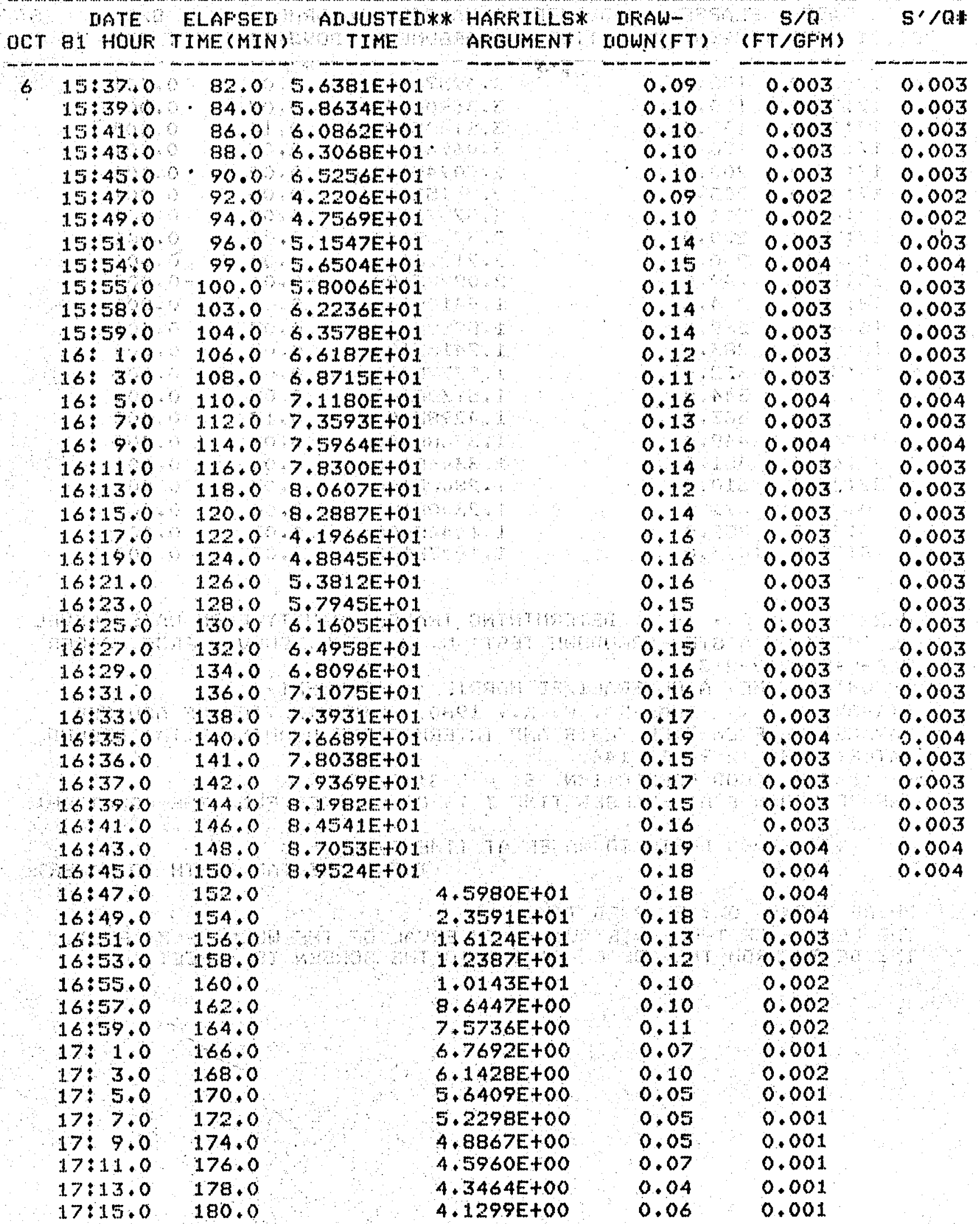


TABLE C-8. (continued)

North observation well step test - -

calculated adjusted timey Harrill's arsument, drawdowng specific drawdown $(s / a)$ and soecific drawdown abjusted for Jacob's correction $\left(s^{\prime} / Q\right.$ )

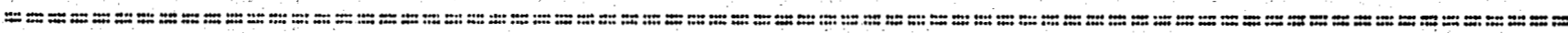

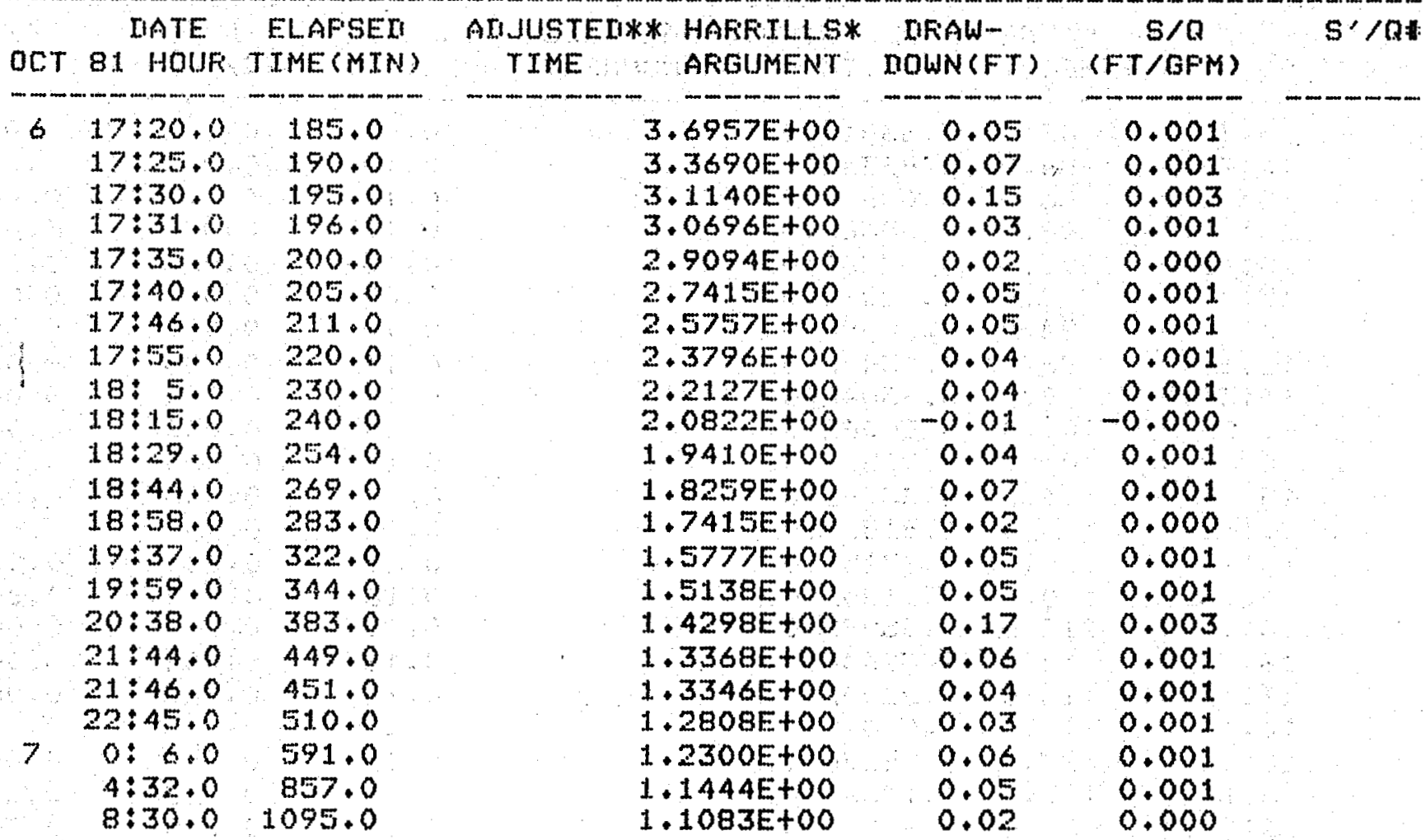

*HARFILL, J. $R$, 1971, RETEFMINING TRANSMISSIUITY FROM WATER-LEUEL. RECOUEFY OF A STEF - IIFAWIIOWN TEST U. S. GEOL. SURU, FFOF. FAFER $700-C, F+C 212-213$.

**ADJUSTED TIME, A GENEFALIZEI HAFFILL'S AFGUMENT,

BIFSOY, $Y$, K. \& SUMMERS, $W$, K., 1980, DETEFMINATION OF AQUTFER PAFAMETEFS FFOM STEF TESTS AND INTERMITTENT FUMFING IIATA GROUNI WATEF, U18, 2 FF137-146.

*S' IS THE JACOB COFFECTION, $5^{\prime}=5-5 * * 2 / 2 \pi$.

THE DRAWDOUN S AT ELAFSEI TIME $T$ IS CALCULATEI FFOM THE EQUATION:

$S$ = (OBSEFUEI DIEFTH TO WATEF AT TIME T)-

(TFENIITINTTAL. IIEFTH TO WATEFI)

WHEFE TREND $O$ * ELAFSEI TIME.

THE LENGTH OF THE CONTFITBUTING INTERUAL OF THE WELL. IS 34 FEET.

THE IIEPTH FFOM THE TOF OF CASING TO THE SCFEEN IS 4 FEET. 


\section{APPENDIX C}

TABLE C-9. South boservetion we1 stertest-water level dete

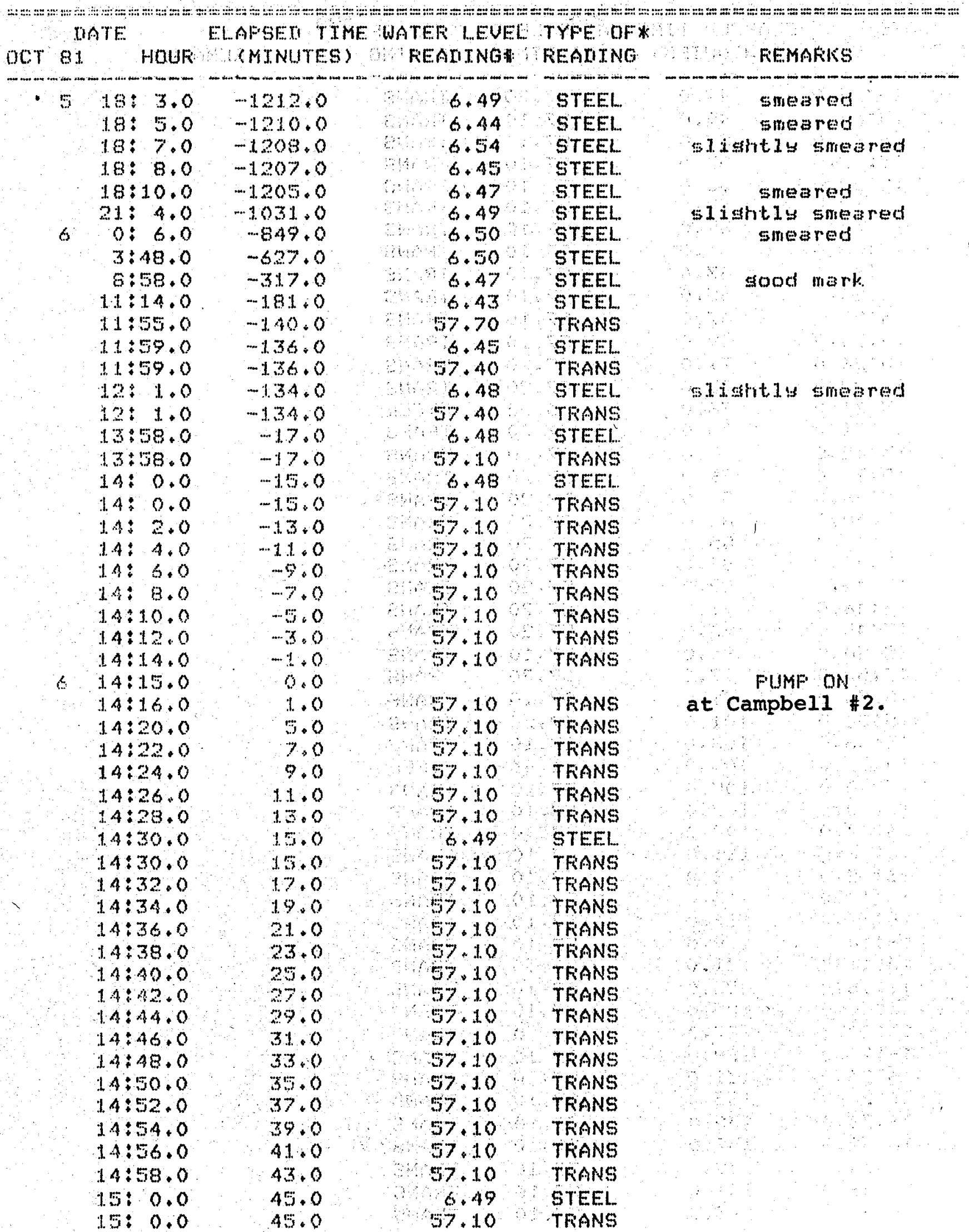


TABLE C-9. (continued)

South observation wal ster test - water level data

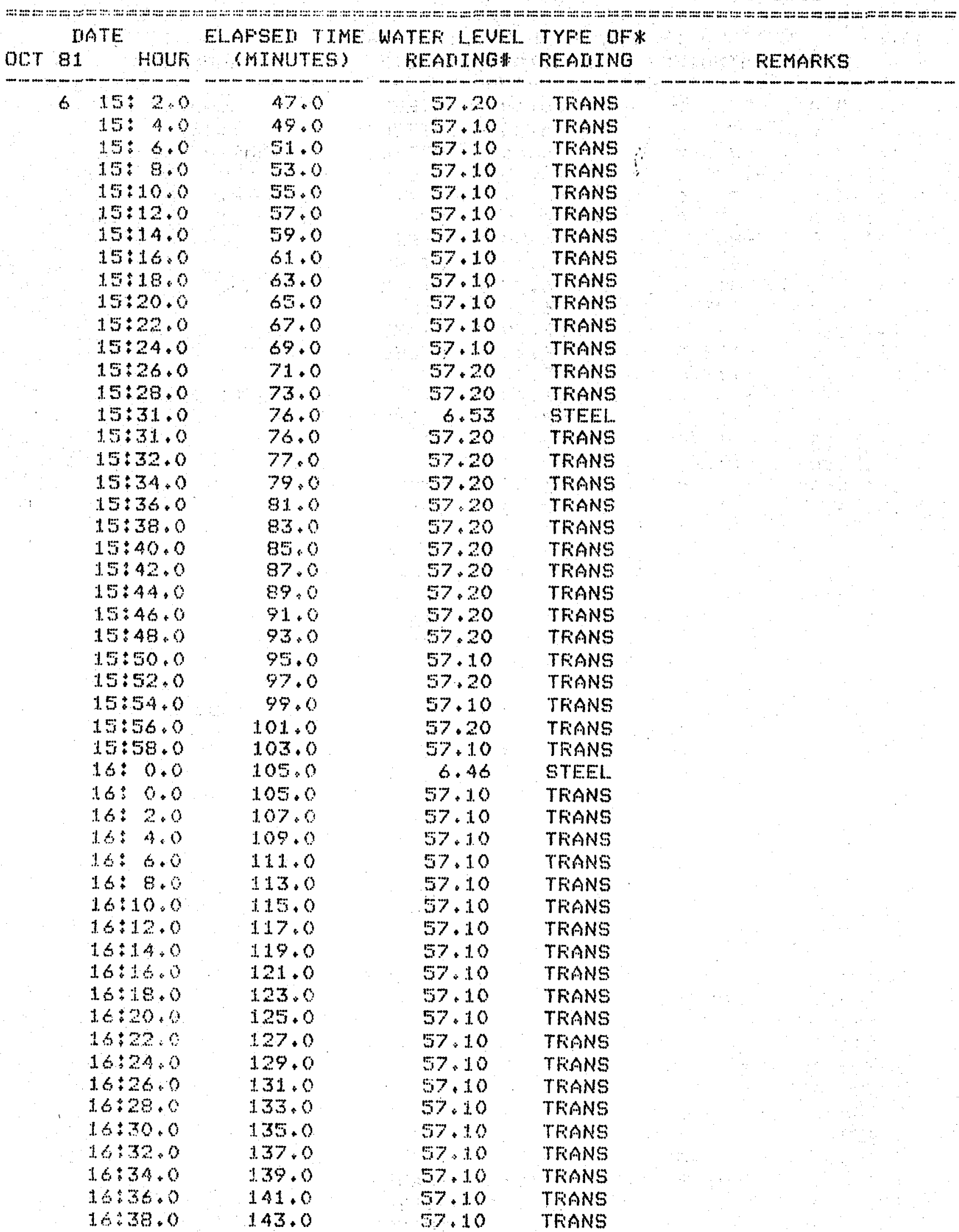


TABLE C-9. (continued)

Sowth observetion wel1 ser test - water level data

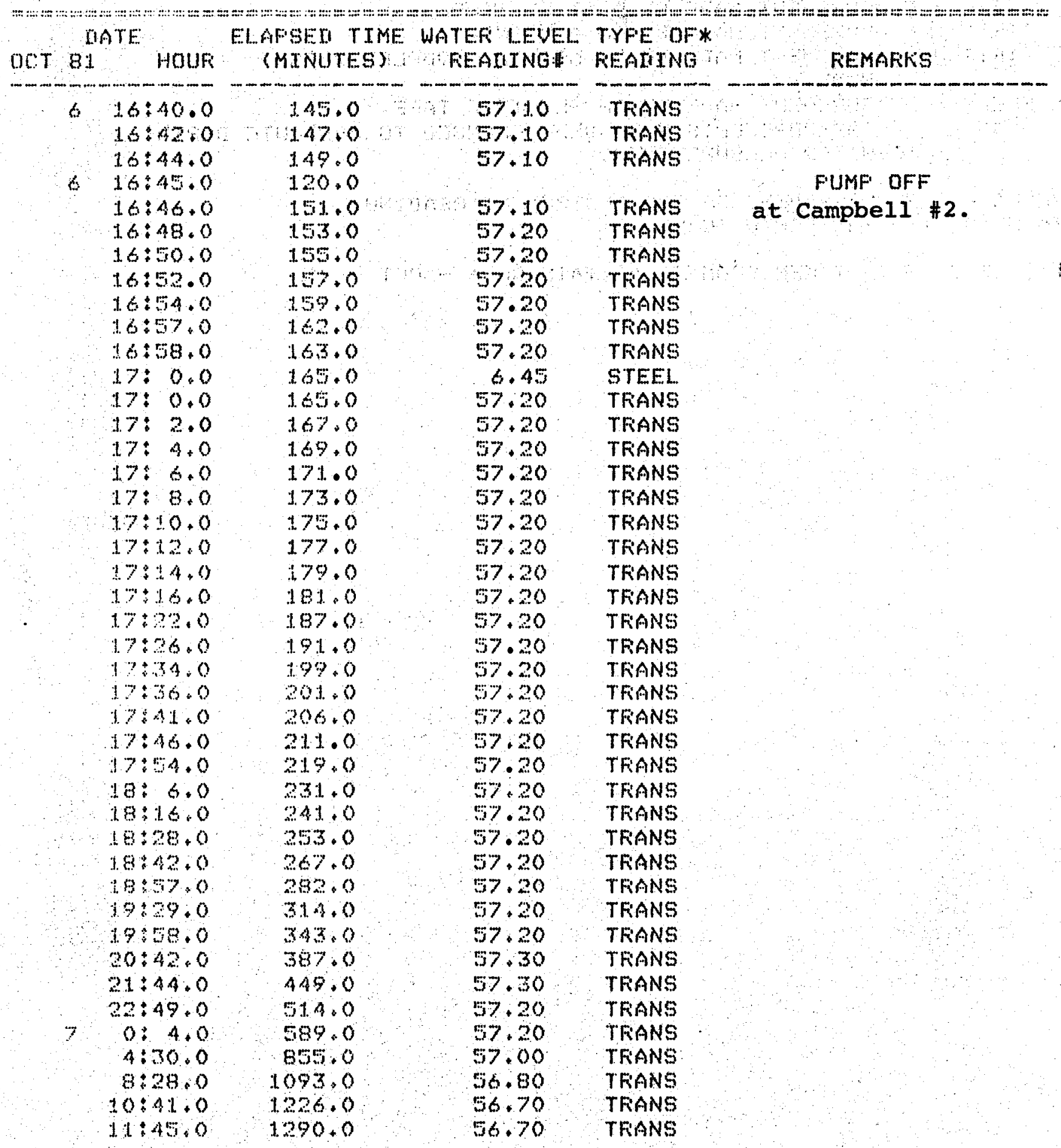

* THE TYFE OF REAITNG DENOTES THE TYFE OF

IEFTH TO WATEF MEASUFEMENT MADE. THESE MAY

BE ANY OF THE FOLLOUTNG:

TFANG:- MEASUREMENT MADE BY A TFANSRIUCEF IN THE WELL. THE MEASUREMENT IS THE HETGHT OF THE WATEF COLUMN 


\section{TABLE C-9. (continued)}

ABOUE THE SEMSOR.

STEEL.: MEASUFEMENT MAIE FY A STEEL TAFE.

ATR:- MEASUREMENT MADE BY AN AIFLINE.

ATFTFAN MEASUFEMENT MADE EY AN AIFLINE COUFLED WTTH A THANSIUCEF.

ELECT MEASUFEMENT MALE BY AN EIECTFIC TAFE.

ABSOL $=$ MLL MEASUFEMENTS HAUE BEEN CHANGET TO AESOLUTE TIEFTHTCWWATER MEASUFEMENTS.

\#THE WATER LEUEL FEAIING IS THE TNSTFUMENT FEARTNG

MADE TO FTH THE REFTH TO WATEF.

ELAFEED TME TS TAKEN FROM TO AT 1415 ON $6-$ OCT - 81 
TABLE C-10.

South observetion we 1 sep tost--dopth to water computations

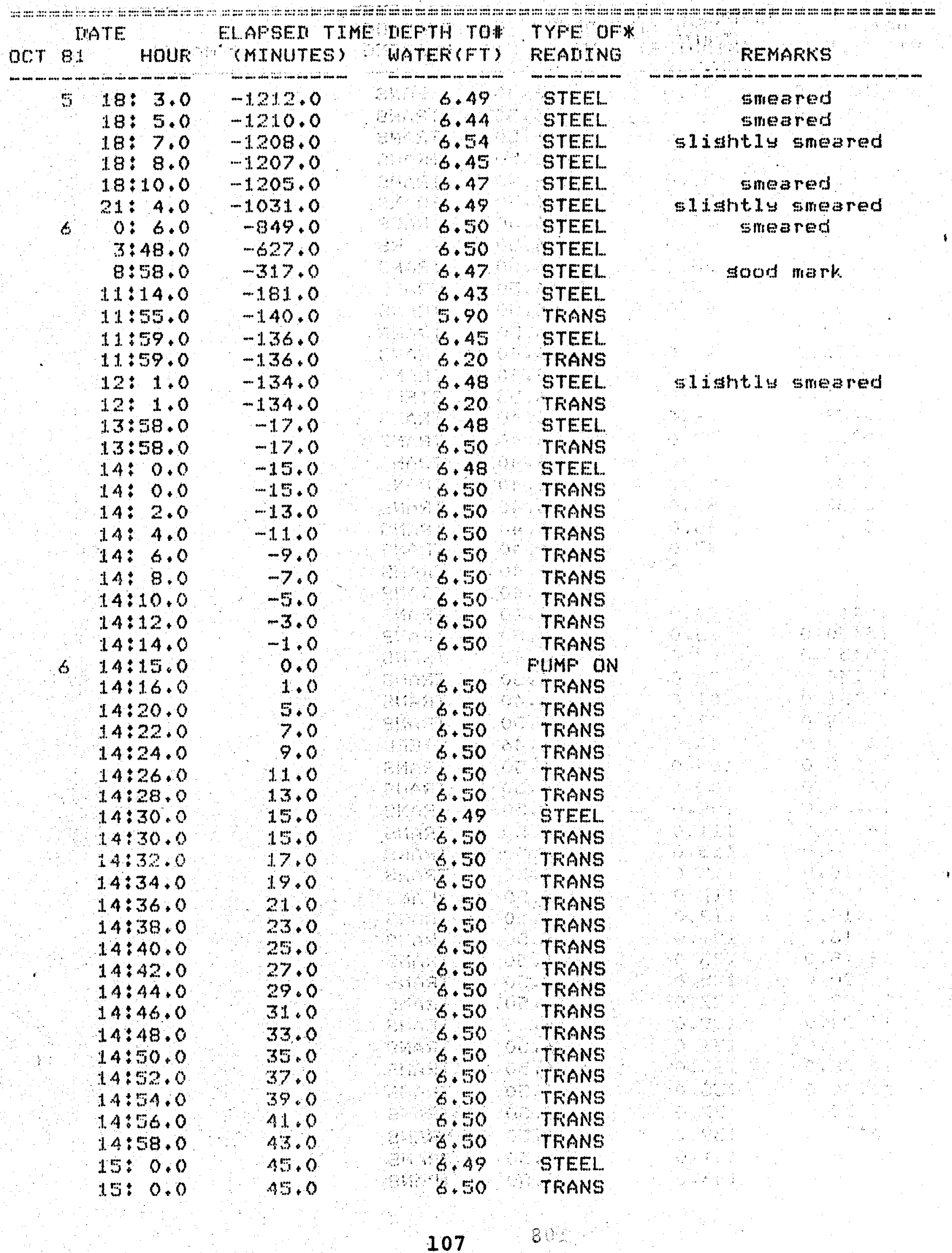


TABLE C-10. (continued)

South observation well ster tegt - depth to water computations

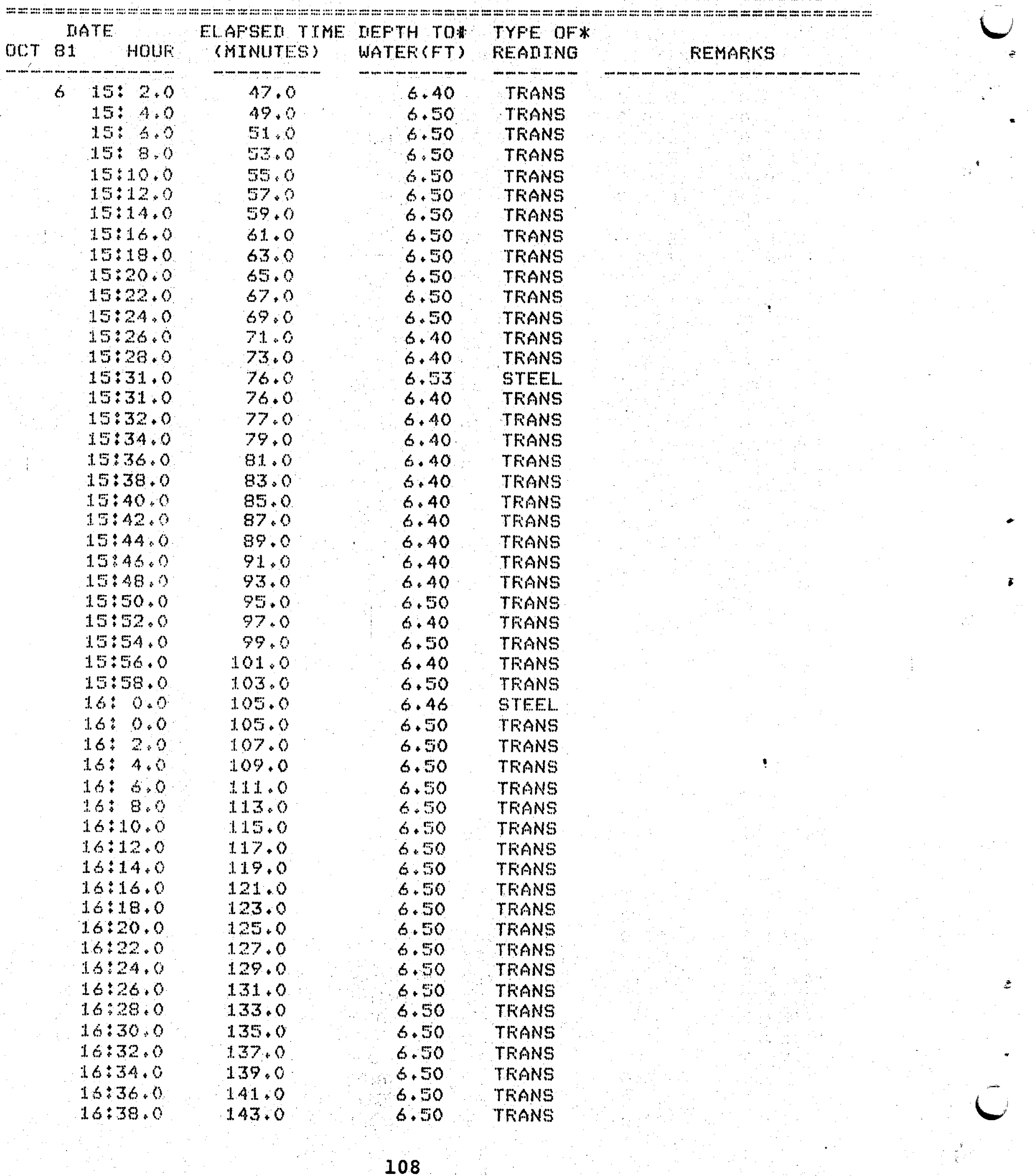


TABIE C-10. (continued)

South observation we1 ster test - befth to water computations

\begin{tabular}{|c|c|c|c|c|c|c|}
\hline \multicolumn{3}{|c|}{ IATE } & \multirow{2}{*}{$\begin{array}{l}\text { ELAFSEI TIME } \\
\text { (MINUTES) }\end{array}$} & \multirow{2}{*}{$\begin{array}{l}\text { DIEFTH TON } \\
\text { WATEF (FT) }\end{array}$} & TYFE OF* & \\
\hline $\mathrm{MT}$ & 81 & HOUFi & & & WEMAKKS & \\
\hline & 6 & $16: 40.0$ & $145 \cdot 0$ & 6.50 & TRANS & \\
\hline & & $16: 42,0$ & 1147.0 & 6.50 & TRIANS & \\
\hline & & $16 \div 44.0$ & 149.0 & 6.50 & TFANS & \\
\hline & 6 & $16: 45.0$ & 150.0 & & PUMF OFF & \\
\hline & & $16: 46.0$ & 151,0 & 6.50 & TFANS & \\
\hline & & $16: 48.0$ & 153.0 & 6.40 & TFANS & \\
\hline & & $16: 50.0$ & $155+0$ & 6.40 & TFANS & \\
\hline & & $16: 52,0$ & $1.57,0$ & 6.40 & TFANS & \\
\hline & & $16: 54+0$ & $=159.0$ & 6.40 & TRANS: & \\
\hline & & $16: 57,0$ & 162.0 & 6.40 & TFANS & \\
\hline & & $16: 58.0$ & 163.0 & 6.40 & TFIANS & \\
\hline & & $17: 0.0$ & 11650 & 649 & STEEI... & \\
\hline & & $17: 0.0$ & 165.0 & 6.40 & TFANS & \\
\hline & & $17: 2.0$ & $16 \% .0$ & 6.40 & TFANS & \\
\hline & & $17: 4.0$ & 169.0 & 6.40 & TFIANS & \\
\hline & & $17: 6.0$ & $171 \% 0$ & 6.40 & TFANS & \\
\hline & & $17: 0.0$ & 173.0 & 6.40 & TFANS & \\
\hline & & $17: 10.0$ & 175.0 & 6.10 & TRANS & \\
\hline & & $17: 12.0$ & 177.0 & 6.40 & TFIANS & \\
\hline & & $17: 14.0$ & 179.0 & 6.40 & TFIANS & \\
\hline & & $17: 16.0$ & 181.0 & 6.40 & TFIANS & \\
\hline & & $17: 22.0$ & 187.0 & 6.40 & TFIANS & \\
\hline & & $17: 26.0$ & 191.0 & 6.40 & TFANS & \\
\hline & & $17: 31.0$ & 199.0 & 6.40 & TFIANS & \\
\hline & & $17: 36.0$ & 201.0 & 6.40 & TFANS & \\
\hline & & $17: 41.0$ & 206.0 & 6.40 & TFANS & \\
\hline & & $17: 46.0$ & 211.0 & 6.40 & TFANS & \\
\hline & & $17: 54.0$ & 219.0 & 6.40 & TFANS & \\
\hline & & $18: 5.0$ & $231 \cdot 0$ & 6.40 & TFANS & \\
\hline & & $\begin{array}{r}18: 16.0 \\
18: 28.0\end{array}$ & $\begin{array}{l}241.0 \\
253.0\end{array}$ & $\begin{array}{l}6.40 \\
6.40\end{array}$ & $\begin{array}{l}\text { TFANS } \\
\text { TFANS }\end{array}$ & \\
\hline & & $\begin{array}{l}18 \div 28.0 \\
18 \div 42.0\end{array}$ & $\begin{array}{l}253.0 \\
267.0\end{array}$ & $\begin{array}{l}6.40 \\
6.40\end{array}$ & $\begin{array}{l}\text { TFANS } \\
\text { TFANS }\end{array}$ & \\
\hline & & $\begin{array}{r}18: 42.0 \\
18: 57.0\end{array}$ & $\begin{array}{l}267+0 \\
282.0\end{array}$ & $\begin{array}{l}6+40 \\
6+40\end{array}$ & $\begin{array}{l}\text { TFANS } \\
\text { TFIANS }\end{array}$ & \\
\hline & & $19: 29.0$ & 314.0 & 6.40 & TFANS & \\
\hline & & $19: 58.0$ & 343.0 & 6.40 & TFANS & \\
\hline & & $20: 42,0$ & 387.0 & 6.30 & TFANS & \\
\hline & & $2 x: 44 \cdot 0$ & 449.0 & 6.30 & TRANS & \\
\hline & & $22: 49.0$ & 514.0 & 6.40 & TKANS & \\
\hline & 7 & $0: 4.0$ & 589.0 & 6.40 & TRANS & \\
\hline & & $4: 30.0$ & 8550 & 6.60 & TFANS & \\
\hline & & $8 \div 28.0$ & 1093.0 & 6.80 & TFANS & \\
\hline & & $10: 41.0$ & 1226.0 & 6.90 & TFIANS & \\
\hline & & $11: 4500$ & 1290.0 & 6.90 & TRANS & \\
\hline
\end{tabular}

*THE TYFE OF FEAOTNG DENOTES THE TYFE OF

DEFTH TO WATER MEASUREMENT MAIE, THESE MAY

BEE ANY OF THE FOLLOWTNG:

TFANS=: MEASUFEMENT MADE BY A TFANSIUCER IN THE WELL.

THE MEASUFEMENT IS THE HEIGHT OF THE WATER COLUMN 
TABLE C-10. (continued)

AEOUE THE SENSOR.

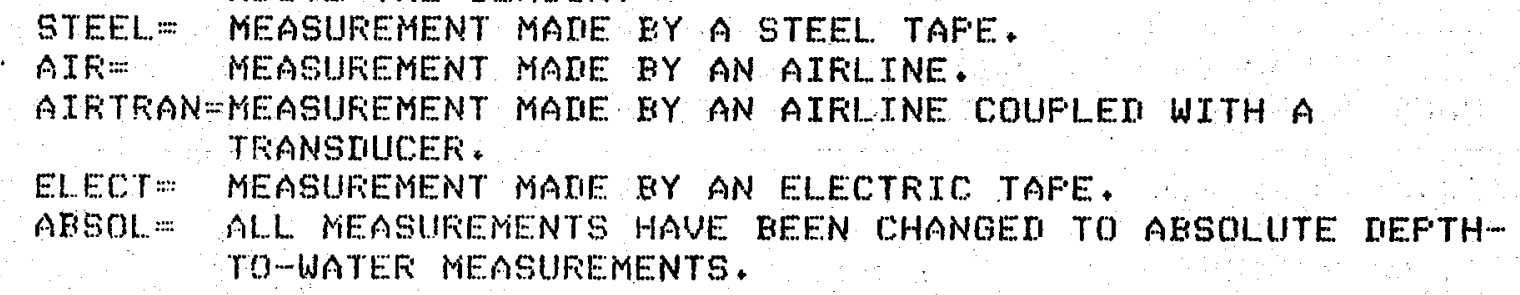

\#THE IIEFTH TO WATEF IS THE CALCULATED DEFTH TO WATEF

FFOM THE TOF OF THE WELL CASTNGY + 2 FEET AROUE THE :

LANII SUFFACE。

THE DEFTH TO WATER BELOW THE TOF OF THE CASING IS COMFUTEA BY THE FORMULA,

FOF TFANS , TEFTH TO WATEF $=63.6$ - WATEF LEUEL FEATING

FDF STEEL, IEFTH TO WATEF : WATEF LEUEL FEAIING

ELAFGEN TIME IS TAKEN FFOM TO AT 1415 ON $6-$ OCT - 81 
TABLE C-11. South observatior we1l ster test calculated adjusted times Harrill's arsument, drawdown, sfecifie drawdown $(s / a)$ arad spocific drawdowriadiusted for Jacob's correction $\left(s^{\prime} / Q\right)$

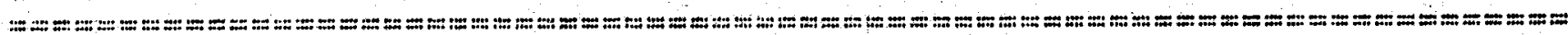

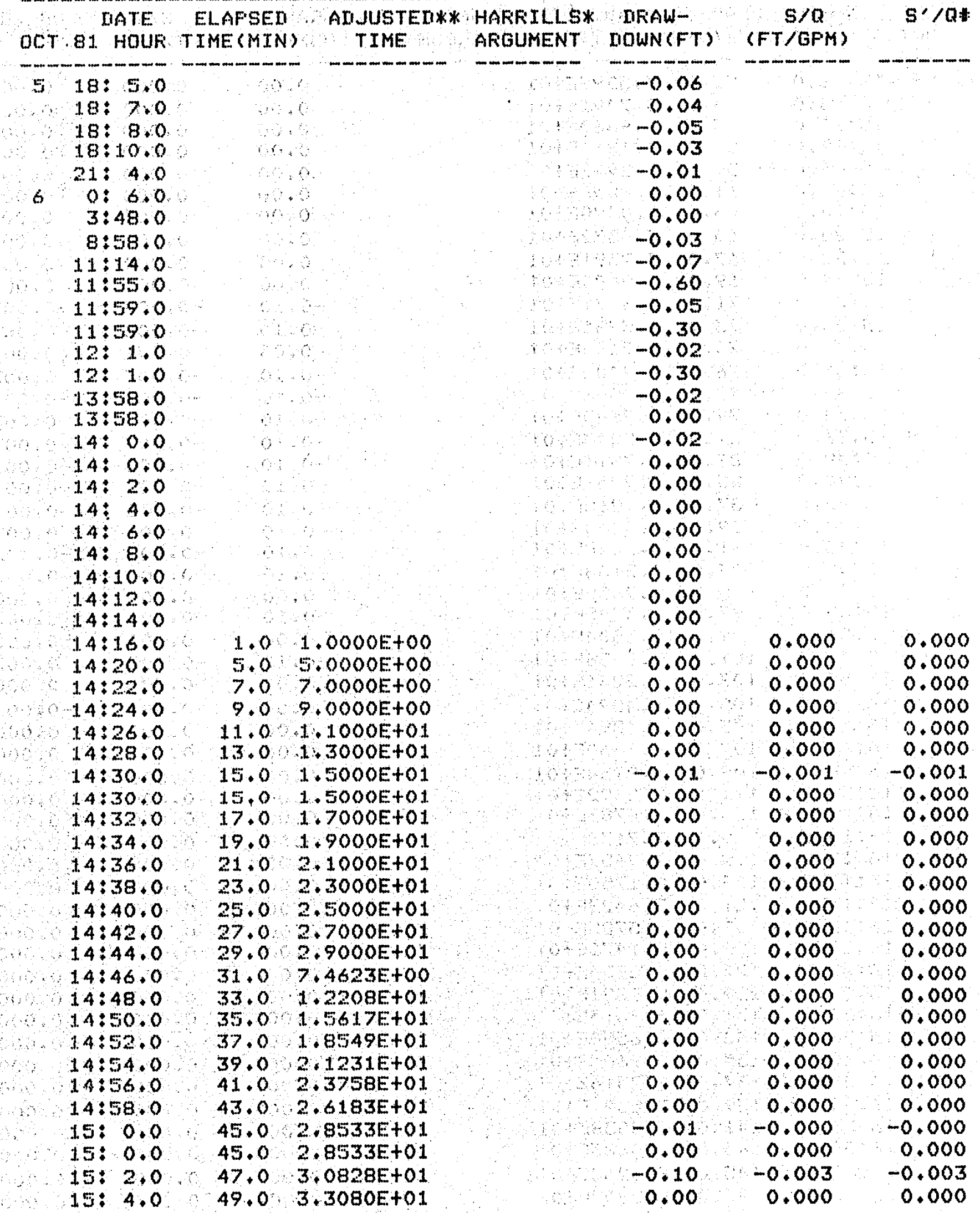


TABLE C-11: (continued)

South observation well step test -

calctiated adiusted time, Harrill's argumert. drawdowr, specific drawdown $(s / a)$ and specific drawdown adjusted for Jacob's correction (s'/a)

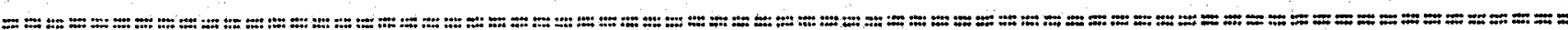

IIATE

ELAFSER

QCT 81 HOUF TIME (MIN)

6

$15: 6.0$

$15: 8.0$

$15: 10.0$

$15: 12.0$

$15: 14.0$

$15: 16.0$

$15: 18.0$

$15: 20.0$

$15: 22.0$

$15: 24.0$

$15 \div 26.0$

$15: 28,0$

$15 \div 31.0$

$15 \div 31.0$

$15: 32.0$

$15: 34.0$

$15: 36.0$

$15: 38.0$

$1.5: 40.0$

$15: 42.0$

$15 \div 44.0$

$15: 46.0$

$15: 48.0$

$15: 50.0$

$15: 52.0$

$15: 54.0$

$15 \div 56.0$

$15: 58.0$

16: 0.0

$16: 0.0$

$16: 2.0$

$16: 4.0$

$16: 6.0$

$16: 8.0$

$16: 10.0$

$16: 12.0$

$16: 14.0$

$16: 16.0$

$16: 18.0$

$16: 20.0$

$16: 22.0$

$16: 24.0$

$16: 26.0$

$16: 28.0$

$16: 30.0$

$16: 32.0$

$16: 34.0$

$16: 36.0$

$16: 38.0$

$16: 40.0$

$16: 42.0$
ADJUSTEI**

TIME

HAFRILLS* IIFAW-
AFGUMENT DOWN (FT)

$\therefore$

$55.0 \quad 3.9660 \mathrm{E}+01$

57.0 4.1811E+01.

$59.0 \quad 4.3947 E+01$

61.0 2.4506E+01

$63.0 \quad 3.0490 E+01$

$65.0 \quad 3.4372 E+01$

$67.0 \quad 3.7591 E+01$

$69.0 .4 .0480 E+01$

$71.0 \quad 4.3171 E+01$

73.0

76.0

76.0

77.0

79.0

81.0

83.0

85.0

87.0

89.0

91.0

93.0

95.0

97.0

99.0

101.0

103.0

105.0

105.0

107.0

109.0

111.0

113.0

115.0

117.0

119.0

121.0

123.0

125.0

127.0

129.0

131.0

133.0

135.0

137.0

139.0

141.0

143.0

145.0

147.0
4.5731 E+01

A. $9404 E+01$

4. $9404 E+01$

$5.0596 E+01$

5. 2940E+01

$5.5243 E+01$

$5+7511 E+01$

$5.9751 E+01$

6. $1968 E+01$

$6.4164 E+01$

$3.7948 E+01$

$4.5166 E+01$

$A .9659 E+01$

5. $3295 E+01$

$5.6504 E+01$

5 . $9456 E+01$

6. $2236 \mathrm{E}+01$

$6.4894 E+01$

$6.4894 E+01$

$6.7460 E+01$

$6.9954 E+01$

7. 2392E+01.

$7.4783 E+01$

$7.7136 E+01$

7.9457E+01

8. $1750 E+01$

3.6428E+01

$4.5785 E+01$

5. 1.471E+01

$5.5954 E+01$

5.9821E+01

$6.3313 E+01$

$6.6550 E+01$

$6.9602 E+01$

7. $2516 \mathrm{E}+01$

$7.5321 \mathrm{E}+0.1$

$7.8038 E+01$

$8.0683 E+01$.

8. $3268 E+01$

8.5802E+01 $s / 0$

(FT/GFM)

0.00
0.00
0.00
0.00
0.00
0.00
0.00
0.00
0.00
0.00

$-0.10$

$-0.10$

0.03

$-0.10$

$-0.10$

$-0.10$

$-0.10$

$-0.10$

$-0.10$

$-0.10$

$-0.10$

$-0.10$

$-0.10$

0.00

$\ldots .10$

0.00

$-0.10$

0.00

$-0.04$

0.00

0.00

0.00

0.00

0.00

0.00

0.00

0.00

0.00

0.00

0.00

0.00

0.00

0.00

0.00

0.00

0.00

0.00

0.00

0.00

0.00

0.00

$-0.003$

$-0.003$

$-0.003$

$-0.003$

$-0.003$

$-0.003$

$-0.003$

$-0.002$

$-0.002$

0.000

$-0.002$

0.000

$-0.002$

0.000

$-0.001$

0.000

0.000

0.000

0.000

0.000

0.000

0.000

0.000

0.000

0.000

0.000

0.000

0.000

0.000

0.000

0.000

0.000

0.000

0.000

0.000

0.000

0.000

$s^{\prime} / 0 *$

$\begin{array}{rr}0.000 & 0.000 \\ 0.000 & 0.000 \\ 0.000 & 0.000 \\ 0.000 & 0.000 \\ 0.000 & 0.000 \\ 0.000 & 0.000 \\ 0.000 & 0.000 \\ 0.000 & 0.000 \\ 0.000 & 0.000 \\ 0.000 & 0.000 \\ -0.003 & -0.003 \\ -0.003 & -0.003 \\ 0.001 & 0.001\end{array}$

$-0.003$

$-0.003$

$-0.003$

$-0.003$

$-0.003$

$-0.003$

$-0.003$

$-0.003$

$-0.002$

$-0.002$

0.000

$-0.002$

0.000

$-0.002$

0.000

$-0.001$

0.000

0.000

0.000

0.000

0.000

0.000

0.000

0.000

0.000

0.000

0.000

0.000

0.000

0.000

0.000

0.000

0.000

0.000

0.000

0.000

0.000

0.000 
TABLE C-11. (continued)

South Dbservation we11 sterstest - -

calculated adjusted time, Harril1's argument, drawdown, sfecific drawdown $(s / a)$ and specific drawdown adjusted for Jacob's correction ( $\left.s^{\prime} / a\right)$

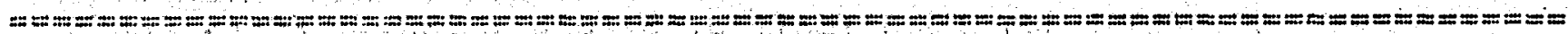

MATE

OCT 81 HOUR TIME(MIN)

-

\section{ELAFSEI}

$16: 46.0$

$16: 48.0$

$16: 50,0$

$16: 52,0$

$16: 54.0$

$16: 57,0$

$16: 58.0$

$17: 0.0$

$17: 0.0$

$17 \div 2.0$

$17: 4.0$

$17: 6.0$

17: 8.0

$17: 10.0$

$17: 12.0$

$17: 14.0$

$17 \div 16.0$

$17: 22.0$

$17: 26: 0$

$17: 34,0$

$17 \div 36.0$

$17: 41.0$

$17 \div 46.0$

$17: 54 \cdot 0$

$18: 6.0$

$18 \div 1.6 .0$

$18: 28.0$

$18 \div 42.0$

$18: 57.0$

$19: 29.0$

$19 \div 58,0$

$20 \div 42.0$

$21: 44.0$

$22 \div 49.0$

$70: 4.0$

$4: 30.0$

$8 \div 28.0$

$10: 41.0$

$11: 45.0$
$149,0,8.8293 E+01$

151.0

153.0

155,0

157.0

159.0

162.0

163.0

165.0

165.0

167.0

169.0

171.0

173.0

175.0

177.0

179.0

181.0

187.0

191.0

199.0

201.0

206.0

211.0

219.0

231.0

241.0

253.0

267.0

282.0

314.0

343.0

387.0

449.0

51.4 .0

589.0

855.0

1093.0

1226.0

1290.0

\section{ADJUSTE[I** HAFFILLS*} ARGUMENT

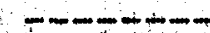

$9.0746 E+01$

$3.1055 E+01$

1. $9111 E+01$

$1.3989 E+01$

1.1140E+01

8. 6447E+00

$8.0681 E+00$

$7.1447 \mathrm{E}+00$

$7.1447 E+00$

6.4377E+00

$5.8787 E+00$

$5.4256 E+00$

$5.0508 E+00$

$4.7356 E+00$

$4.4666 E+00$

$4.2344 E+00$

$4.0319 E+00$

$3.5545 E+00$

$3.3131 \mathrm{E}+00$

$2.9470 E+00$

$2,8732 E+00$

$2.711 .4 E+00$

2.5757E+00

$2.3989 E+00$

$2.1982 E+00$

$2.0707 E+00$

$1.9498 E+00$

$1.8396 \mathrm{E}+00$

1.7470E+00

1. $6051 E+00$

$1.5164 \mathrm{E}+00$

1. $4227 E+00$

$1.3368 E+00$

$1.2777 E+00$

1.2310E+OO

1. 1448E+OO

$1.1086 \mathrm{E}+00$

$1.0953 E+00$

$1.0899 E+00$
IIRAW-

IOWN (FT)

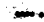$$
-
$$

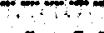

0.00

0.00

$-0.10$

$-0.10$

$-0.10$

$-0,10$

$-0.10$

$-0.10$

$-0.05$

$-0.10$

$-0.10$

$-0.10$

$-0.10$

$-0.10$

$-0.10$

$-0,10$

$-0.10$

$-0.10$

$-0.10$

$-0.10$

$-0.10$

$-0.10$

$-0.10$

$-0.10$

$-0.10$

$-0.10$

$-0.10$

$-0.10$

$-0.10$

$-0.10$

$-0.10$

$-0.10$

$-0.20$

$-0.20$

$-0.10$

$-0.10$

0.10

0.30

0.40

0.40
$S / Q$

(FT/GFM)

$\begin{array}{ll}0.000 & --000 \\ 0.000 & 0.000\end{array}$
$S^{\prime} / Q$

$-0$.

$-0.002$

$-0.002$

$-0.002$

$-0.001$

$-0.002$

$-0.002$

$-0.002$

$-0.002$

$-0.002$

$-0.002$

$-0.002$

$-0.002$

$-0.002$

$-0.002$

$-0.002$

$-0.002$

$-0.002$

$-0.002$

$-0.002$

$-0.002$

$-0.002$

$-0.002$

$-0.002$

$-0.002$

$-0.002$

$-0.002$

$-0.002$

$-0.004$

$-0.004$

$-0.002$

$-0.002$

0.002

0.006

0.008

0.008 


\section{TABLE C-11. (continued)}

*HARFILL, J, R., 1971, IEETERMINING TRANSMISSIUITY FROM WATER-LEVEL RECOUEFY OF A STEF-IFFAWHOWN TEST U, S, GEOL. SUFU, FFOF, FAFER $700-C, F, 0.212-213$.

**ADJUSTEI TIME, A GENEFALIZEN HARFILL'S AFGUMENT, BIFSOY, $Y, K$, \& SUMMEFS, $W$, K, 1980, IIETEFMINATION OF AQUIFER FARAMETEFS FROM STEF TESTS ANI INTERMITTENT FUMFING DATA GROUNI WATEF, V18, 2 FF137-146. \# $5^{\prime}$ IS THE JACOR COFFECTION, $s^{\prime}=s-5 * 2 / 20$. THE IRFAWIOWN $S$ AT ELAFSEN TIME T IS CALCULATED FRUM THE ERUATION: $S=$ (OBSERUEI DEFTH TO WATER AT TIME T)(TRENII INITIAL IIEFTH TD WATER)

WHERE TRENI $=0$ * ELAFSEI TIME.

THE LENGTH OF THE CONTRIEUTING INTERUAL OF THE WELL IS 71 FEET. THE IIEFTH FROM THE TOF OF CASING TO THE SCREEN IS 4 FEET. 


\section{APPENDIX D}

\section{8-HOUR PUMP TEST DATA}

FROM WELL CAMPBELL ET AL. NO. 2 AND

NORTH AND SOUTH OBSERVATION WELLS 


\section{APPENDIX D}

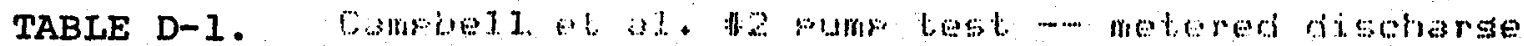

\begin{tabular}{|c|c|c|c|c|c|c|c|c|}
\hline \multicolumn{2}{|c|}{$--D-$ UATE $\cdots-\cdots$} & \multicolumn{2}{|l|}{ ELAFSED } & \multirow{3}{*}{$\begin{array}{l}\text { TOTAL } \\
\text { IIISCHAFIGE } \\
\text { (U, GAL) }\end{array}$} & \multirow{2}{*}{$\begin{array}{l}\text { FUNNING } \\
\text { AUEFAGE }\end{array}$} & \multicolumn{3}{|c|}{ - - - INCFEMENTAL- - - } \\
\hline DCT & HOUF & TJME & METEF & & & $u$ & & $U / T$ \\
\hline 1981 & (MIT) & $(T \perp y M N)$ & BEAITNG & & $(U / T 1, G F M)$ & (GAL) & (MIN) & (GFM) \\
\hline 7 & $14: 30,0$ & 0.0 & 301800 & - & $-m$ & 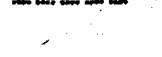 & $-\infty+\infty$ & -- \\
\hline & & & & & & 20 & 0.5 & 40.0 \\
\hline & $1.4: 30.5$ & 0.5 & 301820 & 20 & 40.0 & & & \\
\hline & & & & & & 30 & 0.5 & 60.0 \\
\hline & 246510 & $1+0$ & 301850 & 50 & 50.0 & 30 & 0.5 & 60.0 \\
\hline & $14: 31: 5$ & 1.5 & 301880 & 80 & 53.3 & & & \\
\hline & $14: 32.0$ & 2.0 & 301910 & 11.0 & 55.0 & 30 & 0.5 & 60.0 \\
\hline & & & & & & 50 & 1.0 & 50.0 \\
\hline & $14: 33.0$ & 3.0 & 301960 & 160 & 53.3 & & & \\
\hline & $14: 34.0$ & 4.0 & 302010 & 210 & $52+5$ & so & 1.0 & $50+0$ \\
\hline & & & & & - & 50 & 1.0 & 50.0 \\
\hline & $14: 35,0$ & $j+0$ & 302060 & 260 & 52.0 & & & \\
\hline & $14^{\circ}$ & & 30210 & & & 50 & 1.0 & 50.0 \\
\hline$\vdots$ & $.24: 50+0$ & 6.0 & 302110 & 310 & $51+7$ & 110 & 2.0 & 55.0 \\
\hline & $14: 38.0$ & 8.0 & 302220 & 420 & 52.5 & & & \\
\hline & & & & & & 110 & 2.0 & $55+0$ \\
\hline & $14: 40.0$ & $10+0$ & 3025.30 & $.0,50$ & 5.3 .0 & 570 & 11.0 & 51.8 \\
\hline & $14: 51.0$ & 21.0 & 302900 & 1100 & 52.4 & & & \\
\hline & $15: 0.0$ & 30.0 & 303360 & 1560 & 52.0 & 400 & $4+0$ & $51 \cdot 1$ \\
\hline & $15: 10.0$ & 40.0 & & 2000 & & 520 & 10.0 & 52.0 \\
\hline & $1.5+14+8$ & $40+0$ & 20,3806 & 2000 & $3 x+0$ & 1580 & 30.0 & 52.7 \\
\hline & $15: 10 \div 0$ & $70+0$ & 305460 & 3660 & 52.3 & & & \\
\hline & $10 \div 50.0$ & $80: 0$ & 303940 & 4140 & $51+8$ & 480 & 10.0 & 48.0 \\
\hline & & & & & ont & 520 & 10.0 & 52.0 \\
\hline & $16: 0.0$ & 90.0 & 306460 & 4660 & 51.8 & 500 & 10.0 & 50.0 \\
\hline & $16: 10.0$ & 100,0 & 306960 & 0160 & 31.6 & & $10+6$ & $50+0$ \\
\hline & $16: 30 \cdot 0$ & 120.0 & 307990 & 6190 & $51+6$ & 1030 & 20.0 & 51.5. \\
\hline & & & & & & 1020 & 20.0 & 51.0 \\
\hline & 10.0000 & $1.40 \cdot 0$ & 3090.10 & 7210 & $51+5$ & 1030 & 20.0 & 51.5 \\
\hline & $17: 10 \cdot 0$ & 160.0 & 310040 & 8240 & 51.5 & & & \\
\hline & $17 \div 30.0$ & 180.0 & 311060 & 9260 & 51.4 & 1020 & 20.0 & 51.0 \\
\hline & & & & & & 1030 & 20.0 & 51.5 \\
\hline & $17: 50.0$ & 200.0 & 312090 & 10290 & 51.5 & & & \\
\hline & $18: 10.0$ & 220.0 & & & & 1030 & 20.0 & 51.5 \\
\hline & $10+10 \cdot 0$ & $2-0+8$ & 51.51 .00 & 1. 1320 & 51.5 & 1050 & 20.0 & 52.5 \\
\hline & i. $8: 30.0$ & 240.0 & 3.4170 & J. 2370 & $51+5$ & & & \\
\hline & $18: 50.0$ & 260.0 & 315180 & 13380 & 51.5 & 1010 & 20.0 & 50.5 \\
\hline
\end{tabular}


TABLE D-1. (continued)

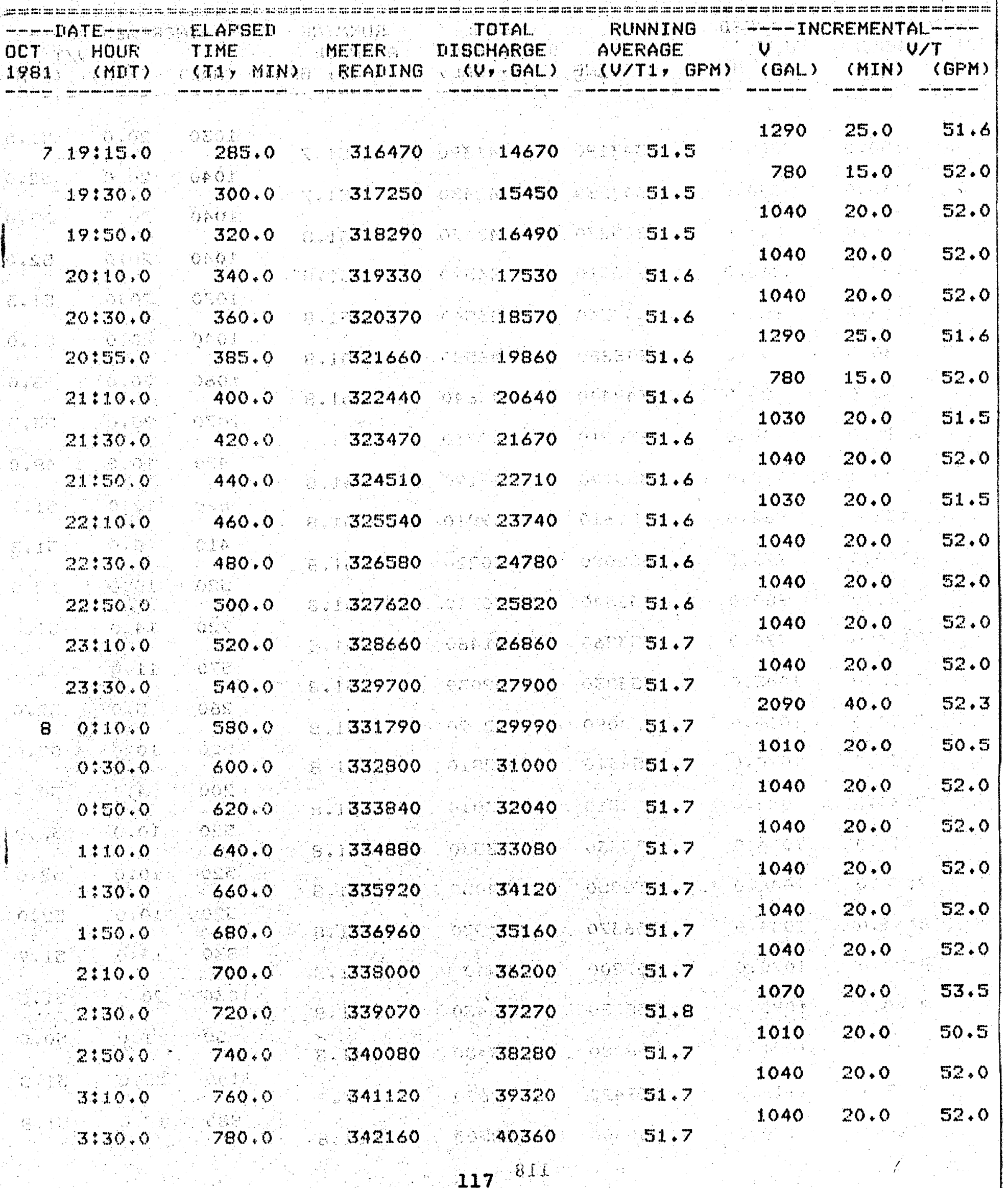

W. N. SUMMEFS AND ASSOCTATES, TNC. 
TABLE D-1. (continued)

Comptrell et al a2 rump test - metered discharse

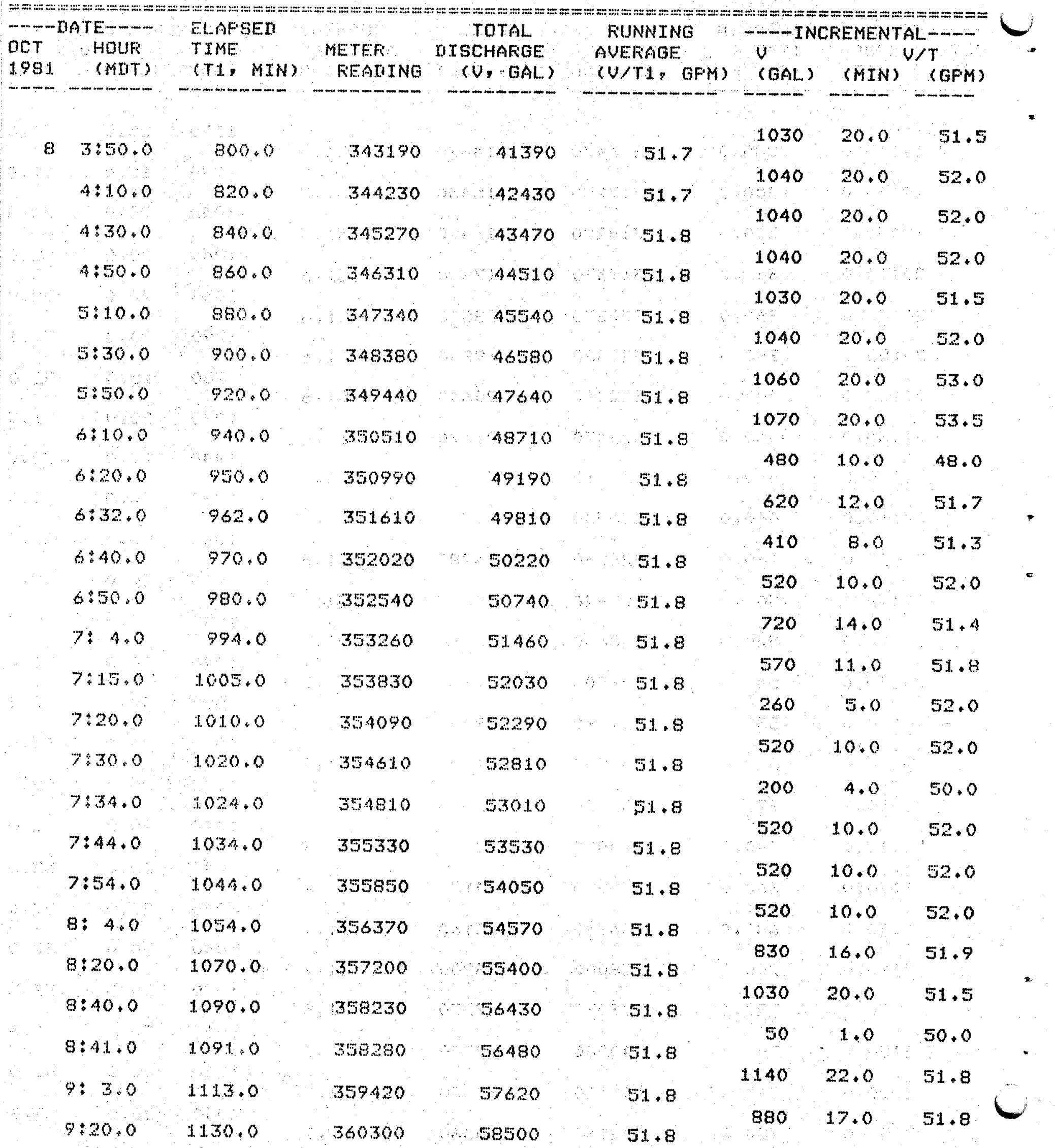


TABLE D-1. (continued)

Cambel1 et 31. H2 fump test - metered discharse

\begin{tabular}{|c|c|c|c|c|c|c|c|c|}
\hline \multirow{2}{*}{\multicolumn{2}{|c|}{$\begin{array}{l}- \text { DATE } \\
\text { OCT HOUE } \\
1981 \text { (MIT) }\end{array}$}} & \multirow{2}{*}{$\begin{array}{l}\text { ELAPSEI } \\
\text { TIME } \\
\text { (T1, MTN) }\end{array}$} & \multirow{2}{*}{$\begin{array}{l}\text { METER } \\
\text { FEAIING }\end{array}$} & TOTAL. & FUUNNING & \multicolumn{3}{|c|}{-- -INCREMENTAL ---} \\
\hline & & & & $\begin{array}{l}\text { DTSCHAFGE } \\
\text { (V, GAL) }\end{array}$ & $\begin{array}{l}\text { AUERAGE } \\
\text { (U/TI, GFM) }\end{array}$ & $\begin{array}{l}U \\
\text { (GAL) }\end{array}$ & (MIN) & $T_{(G F M)}$ \\
\hline & & & & & & 1040 & 20.0 & 52.0 \\
\hline 8 & $9: 40,0$ & 1150.0 & 361340 & 59540 & $51 \cdot 8$ & & & \\
\hline & $10: 1.0$ & 1171,0 & 362430 & 60630 & 3.8 & 1090 & 21.0 & 51.9 \\
\hline & & & & & & 980 & 19.0 & 51.6 \\
\hline & $10 \div 20.0$ & 1190.0 & 363410 & 61610 & 51.8 & & & \\
\hline & $10: 40.0$ & 1210.0 & 364440 & 62640 & 51.8 & 1030 & 20.0 & $51+5$ \\
\hline & & & & & & 1090 & 21.0 & 51.9 \\
\hline & $1: 1: 0$ & 1231.0 & 365530 & 63730 & $51+8$ & & & \\
\hline & $11: 300$ & 1250.0 & & 64710 & 51,8 & 980 & 19.0 & $51 \cdot 6$ \\
\hline & 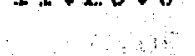 & 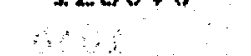 & $3000+6$ & 00 & W. & 1040 & 20.0 & 52.0 \\
\hline & $11: 40.0$ & 1270.0 & 367550 & 65750 & $51 \cdot 8$ & & & \\
\hline & $12: 1.0$ & 1291.0 & 368630 & 66830 & 51,8 & 1080 & 21.0 & $51 \cdot 4$ \\
\hline & tans & & & & & 990 & 19.0 & 52.1 \\
\hline & $12: 20.0$ & 1310.0 & 369620 & 67820 & $51 \cdot 8$ & & & \\
\hline & $1.2: 40,0$ & 1330.0 & 370650 & 68850 & 51.8 & 10.30 & 20.0 & 51.5 \\
\hline & & & & & & 1.140 & 22.0 & 51.8 \\
\hline & $13 \div 2+0$ & $1352 \cdot 0$ & 371790 & 69990 & 51.8 & 930 & 18.0 & 51.7 \\
\hline & $13: 20.0$ & 1370.0 & 372720 & 70920 & 51.8 & & & \\
\hline & $13: 4 x \cdot 0$ & 1393.0 & & & & 1190 & $23+0$ & 51.7 \\
\hline & & & 37.2780 & $?=10$ & 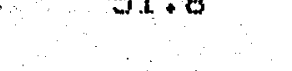 & 1020 & 20.0 & 51.0 \\
\hline & $14: 3.0$ & 1413.0 & 374930 & 73130 & $51 \cdot 8$ & & 0 & 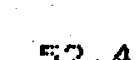 \\
\hline & $14: 20.0$ & 1430.0 & 375820 & 74020 & 51.8 & ( & $4+\infty$ & $\sqrt{3}+4$ \\
\hline & & & & & & 1020 & 20.0 & 51.0 \\
\hline & $14: 40,0$ & 1450.0 & 376840 & 75040 & $51 \cdot 8$ & 1030 & & \\
\hline & $15: 0.0$ & 1470.0 & 377870 & 76070 & 51.7 & 1000 & 20.0 & 31.5 \\
\hline & & & & & & 1040 & 20.0 & 52.0 \\
\hline & $15: 20.0$ & 1490.0 & 378910 & 77110 & 51.8 & & & \\
\hline & $15: 40.0$ & 1510.0 & 379950 & 78150 & $51+8$ & 1. प्रति & 20.6 & $32+\infty$ \\
\hline & $16: 0.0$ & th & 380980 & $791 \quad-1$ & .1 .8 & 1030 & 20.0 & 51.5 \\
\hline & $1000+0$ & 1000000 & 300700 & 7100 & whe & 1040 & 20.0 & 52.0 \\
\hline & $16: 2000$ & 1550.0 & 382020 & 80220 & 51.8 & $\therefore$ & & \\
\hline & $16: 10.0$ & 1570.0 & 383050 & 81250 & 51.8 & & & $51+5$ \\
\hline 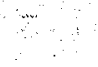 & $17: 00$ & 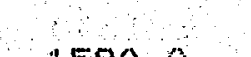 & & & & 1040 & 20.0 & 52.0 \\
\hline & $17 \div 0+0$ & $1570_{4} 0$ & 384090 & 82290 & $21+8$ & 1020 & 20.0 & 51.0 \\
\hline & $17: 20 \cdot 0$ & 1610.0 & 385110 & 83310 & 51.7 & 1050 & & \\
\hline & $17: 40.0$ & 1630.0 & 386160 & 84360 & 51.8 & WJo & 20.0 & $\sqrt{5}+4$ \\
\hline
\end{tabular}

1190

W. K. GUMMEFS AND ASSOCIATES, INC. 
TABLE D-1. (continued)

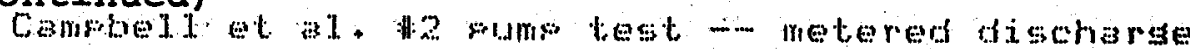

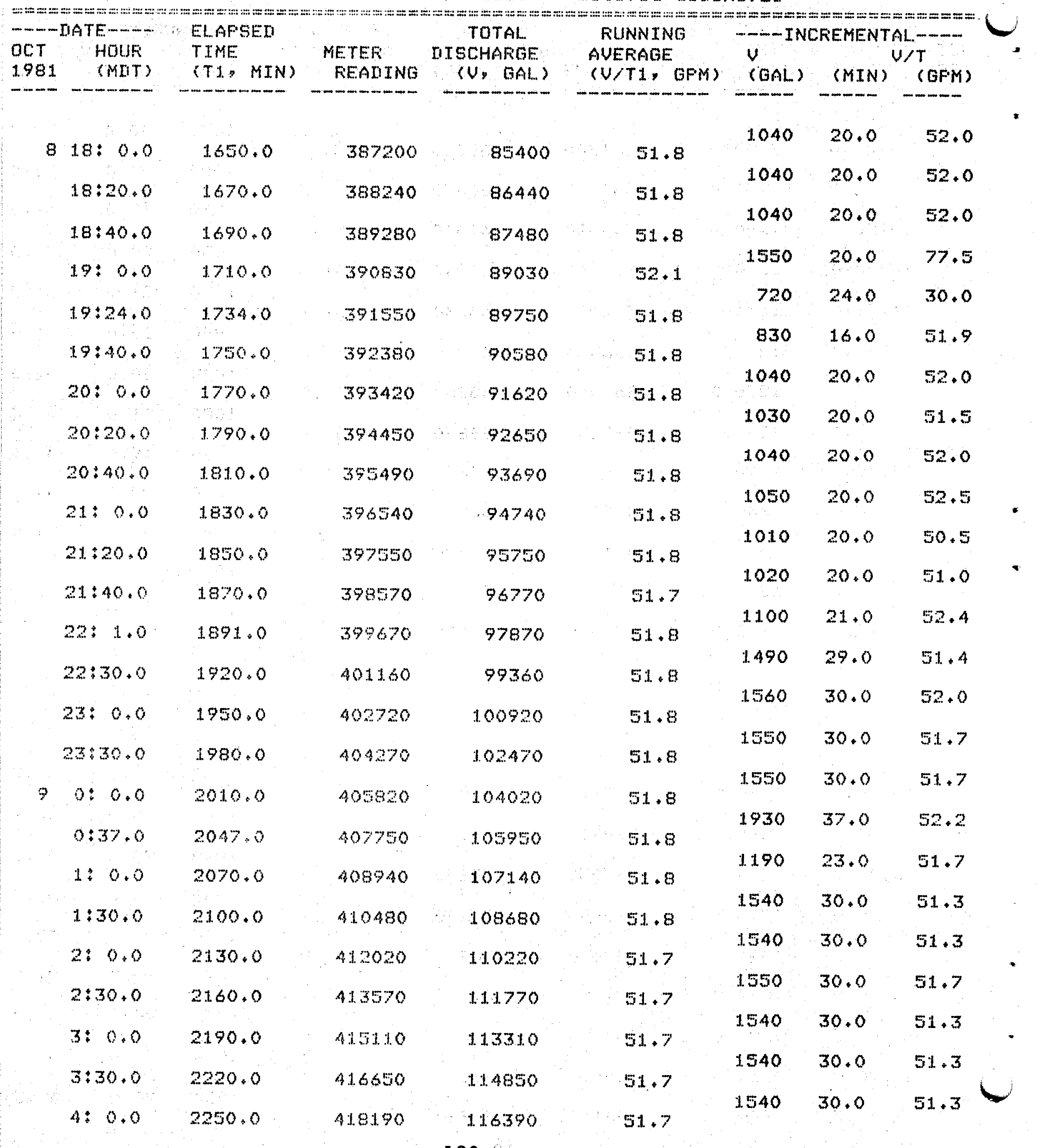


TABLE D-1. (continued) at al. N2 fump tost-- metered discharse

\begin{tabular}{|c|c|c|c|c|c|c|c|c|}
\hline \multicolumn{2}{|c|}{- - IATE- } & \multirow{2}{*}{$\begin{array}{l}\text { ELAFSEI } \\
\text { TIME } \\
\text { (TLY MIN }\end{array}$} & \multirow{2}{*}{$\begin{array}{l}\text { METEF } \\
\text { REAIING }\end{array}$} & \multirow{2}{*}{$\begin{array}{l}\text { TOTAL } \\
\text { ITSCHAFGE } \\
\text { (V, GAL) }\end{array}$} & FUUNNING & \multicolumn{3}{|c|}{--- INCREMENTAL ---} \\
\hline $\begin{array}{l}\operatorname{oct} \\
1981\end{array}$ & $\begin{array}{l}\text { HOUK } \\
\text { (MIT) }\end{array}$ & & & & $\begin{array}{l}\text { AUERAGE } \\
\text { (U/T1, GFM) }\end{array}$ & $\begin{array}{l}v \\
\text { (GAL) }\end{array}$ & (MIN) & (GFM) \\
\hline$\because$ & 0 & 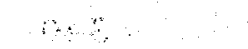 & $\ldots$ & & & 1540 & 30.0 & $51 \cdot 3$ \\
\hline 9 & $4: 30: 0$ & 2280.0 & 419730 & 117930 & 51.7 & & & \\
\hline$\therefore$ & -40 & 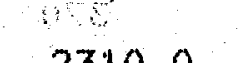 & & & & 1540 & 30.0 & $51 \cdot 3$ \\
\hline & $3: 0.0$ & $\therefore+30+0$ & $4 x+2<10$ & 17470 & & 1540 & 30.0 & 51.3 \\
\hline & $5: 30 \cdot 0$ & 2340.0 & $\therefore \quad 422810$ & 121010 & 51.7 & 1550 & 30.0 & 51.7 \\
\hline & $0: 0.0$ & 2370.0 & $\therefore 424360$ & 122560 & 51.7 & & & \\
\hline & $6: 30 \cdot 0$ & $2400=0$ & 425890 & 124090 & 51.7 & & & \\
\hline & $7 \cdot 90$ & 24300 & 427430 & 125630 & 51.7 & 340 & 30.0 & $51 \cdot 3$ \\
\hline & $7+x+1$ & & & to & & 1570 & 30.0 & $52 \cdot 3$ \\
\hline & $7: 30.0$ & 2460.0 & 429000 & 127200 & 51.7 & & & \\
\hline & $B=0.0$ & 24000 & 430500 & 128720 & 51.7 & 1520 & 30.0 & $50 \cdot 7$ \\
\hline & $0+8+6$ & $2-7.784$ & The & & & 1530 & 30.0 & $51 \cdot 0$ \\
\hline & $8: 30.0$ & 2520.0 & 432050 & 130250 & 51.7 & & & $=5$ \\
\hline & $8: 40,0$ & $2530 \cdot 0$ & 132560 & 130760 & $5 \pi+7$ & 210 & $1.0+0$ & 31.0 \\
\hline & & & & & & 1060 & 20.0 & 53.0 \\
\hline & $9: 0.0$ & 2550.0 & 433620 & 131820 & 51.7 & 1.490 & 30.0 & 49.7 \\
\hline & $9: 30.0$ & 2580.0 & 435110 & 133310 & 51.7 & & & $=07$ \\
\hline & $10: 0.0$ & 2610.0 & 436620 & 134820 & $51+7$ & & +0 & 30.3 \\
\hline & & & & & & 250 & 5.0 & 50.0 \\
\hline & $10: 5+0$ & 26150 & 436870 & 135070 & 51.7 & $12 t$ & 25.0 & 51.2 \\
\hline & 10130.9 & 2640.0 & 438150 & 136350 & 51.6 & & & \\
\hline & $11: 0.0$ & 2670.0 & 939700 & 137900 & $51+6$ & & 0 & 51.7 \\
\hline & 1. $1 .+\infty+\infty$ & & & & & 1500 & 30.0 & 50.0 \\
\hline & $11: 30.0$ & $2700 \cdot 0$ & 441200 & 139400 & 51.6 & & & 0 \\
\hline & $12: 0.0$ & 2730.0 & 442730 & 140930 & 51.6 & & & \\
\hline & & & 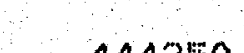 & 0 & $=1$ & & 0 & 7 \\
\hline & $12: 30,0$ & 2760.0 & $944 \sin$ & $124 \times 400$ & $1+0$ & 1520 & 30.0 & 50.7 \\
\hline & $13: 0.0$ & 2790.0 & 445770 & 1.43970 & 51.6 & 2280 & 45,0 & 50.7 \\
\hline & $13: 45.0$ & 2835.0 & 448050 & 146250 & $51 \cdot 6$ & & & \\
\hline & $1 \mathrm{~A}: 0.0$ & 2850.0 & 498800 & 147000 & 51.6 & & & 00.0 \\
\hline & & & & & & 310 & 6.0 & 51.7 \\
\hline & $18: 6+0$ & 2856.0 & 449110 & 147310 & 51.6 & & & 0 \\
\hline & $14: 7.0$ & 2857.0 & 449160 & 147360 & 51.6 & & & \\
\hline & $14: 8,0$ & 2858.0 & 449210 & 147410 & 51.6 & & 0 & \\
\hline & & & & $121 \leq 5$ & & & & \\
\hline
\end{tabular}

4. K. SUMMERS ANI ASSOCIATES, INC. 
TABLE D-1. (continued)

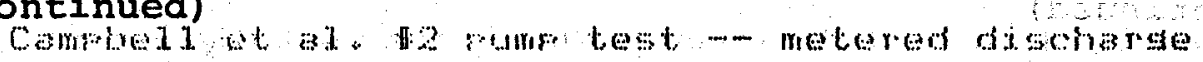

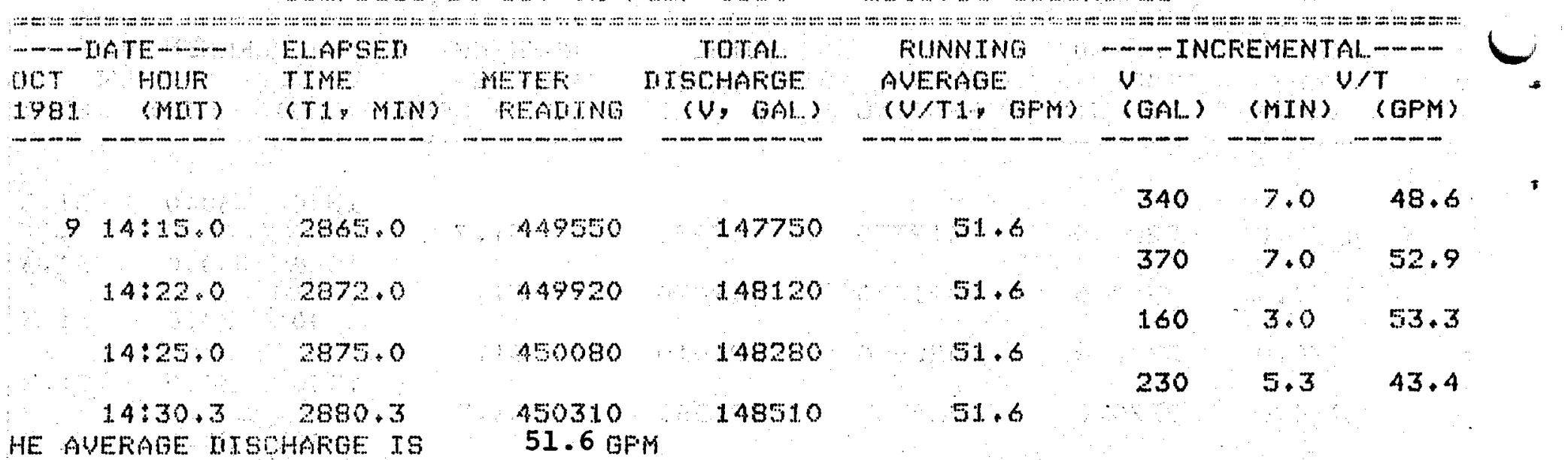




\section{APPENDIX D}

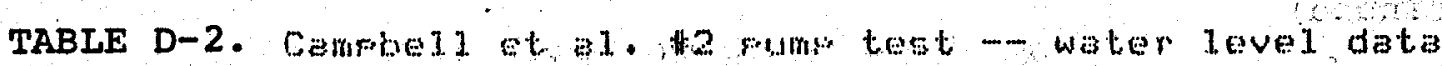

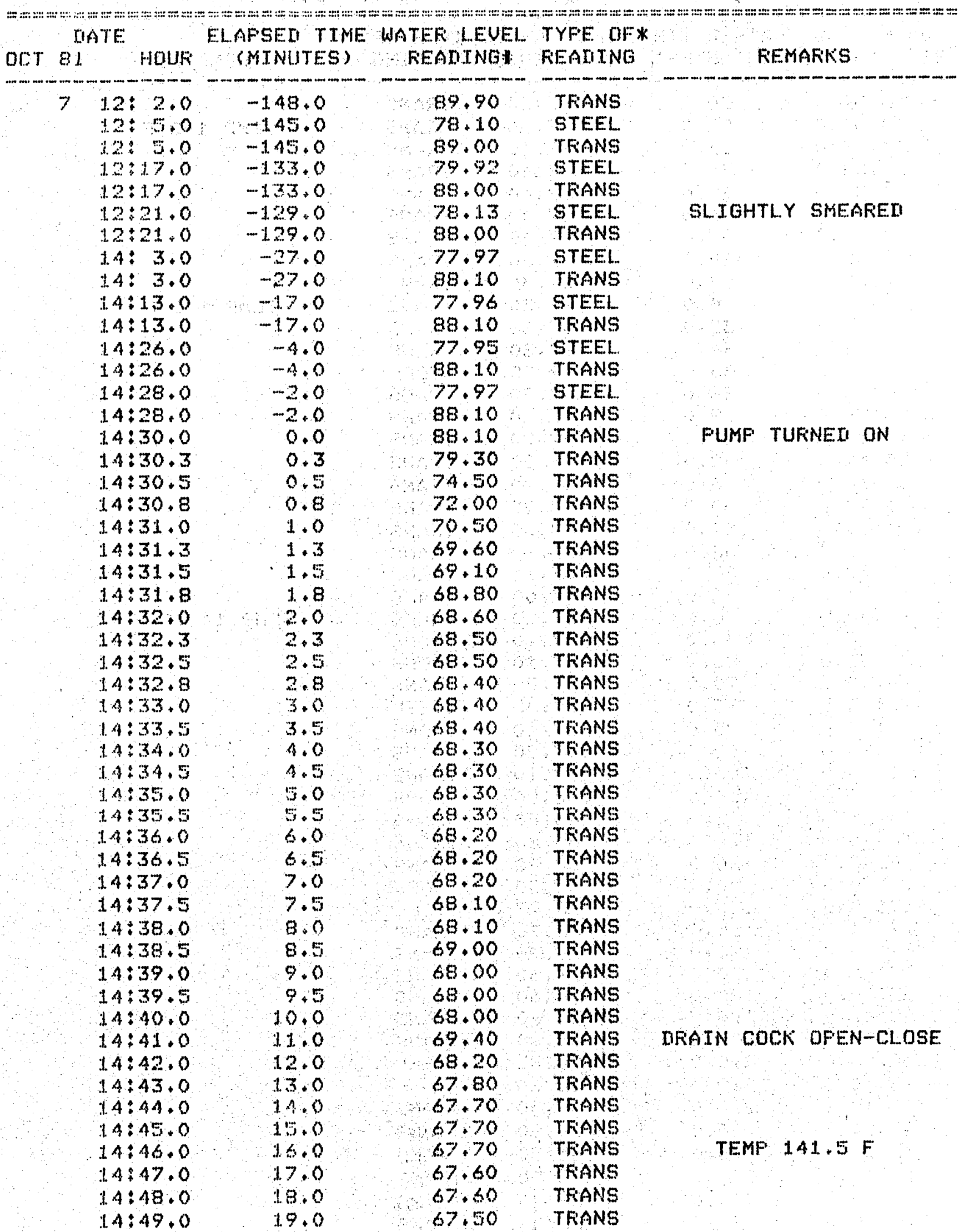


TABLE D-2. (continued)

[ampbal. at al. ha fom test w. water lovel data

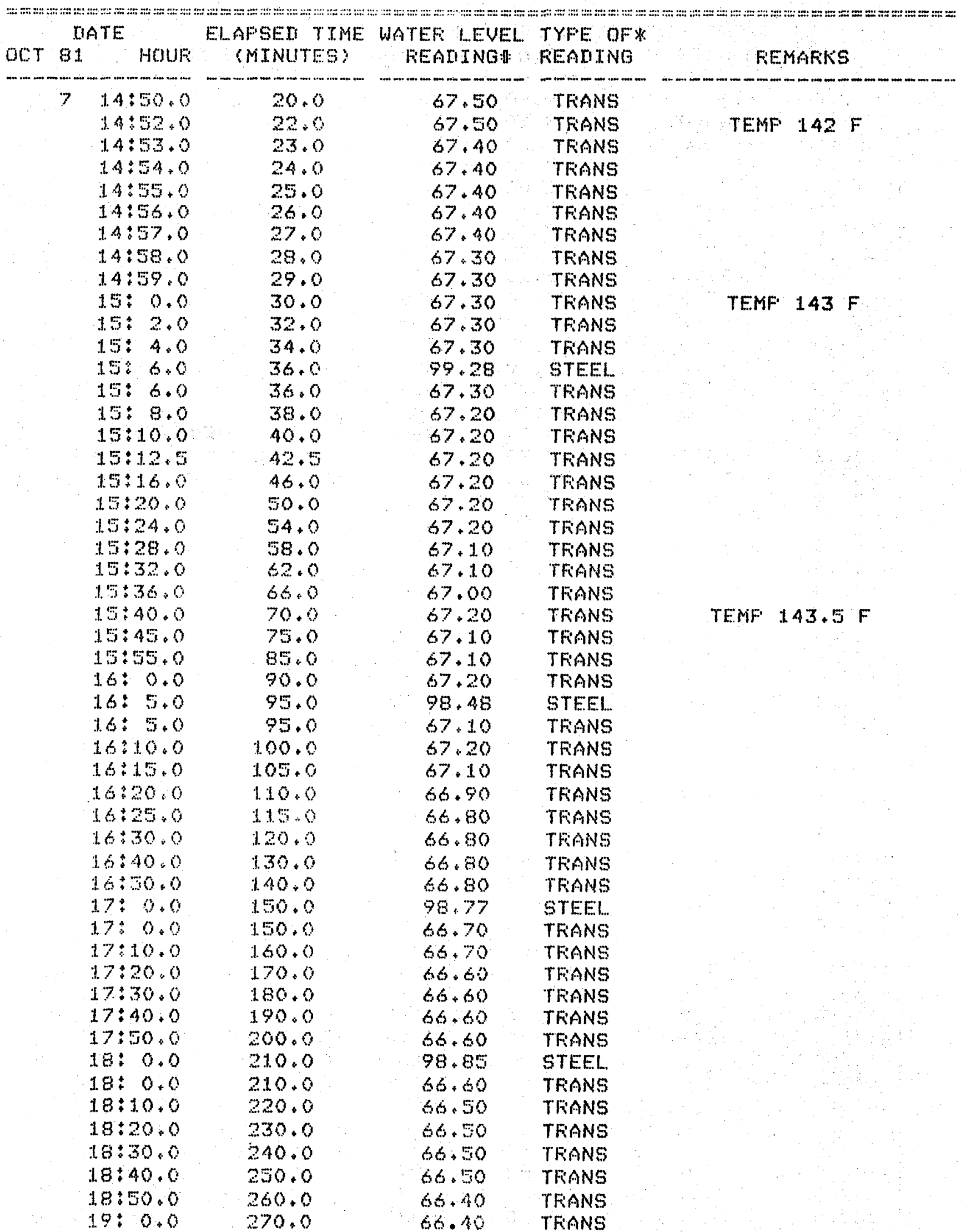


TABLE D-2. (continued)

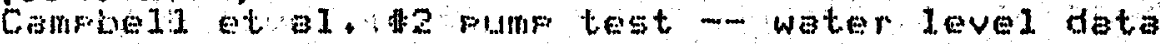

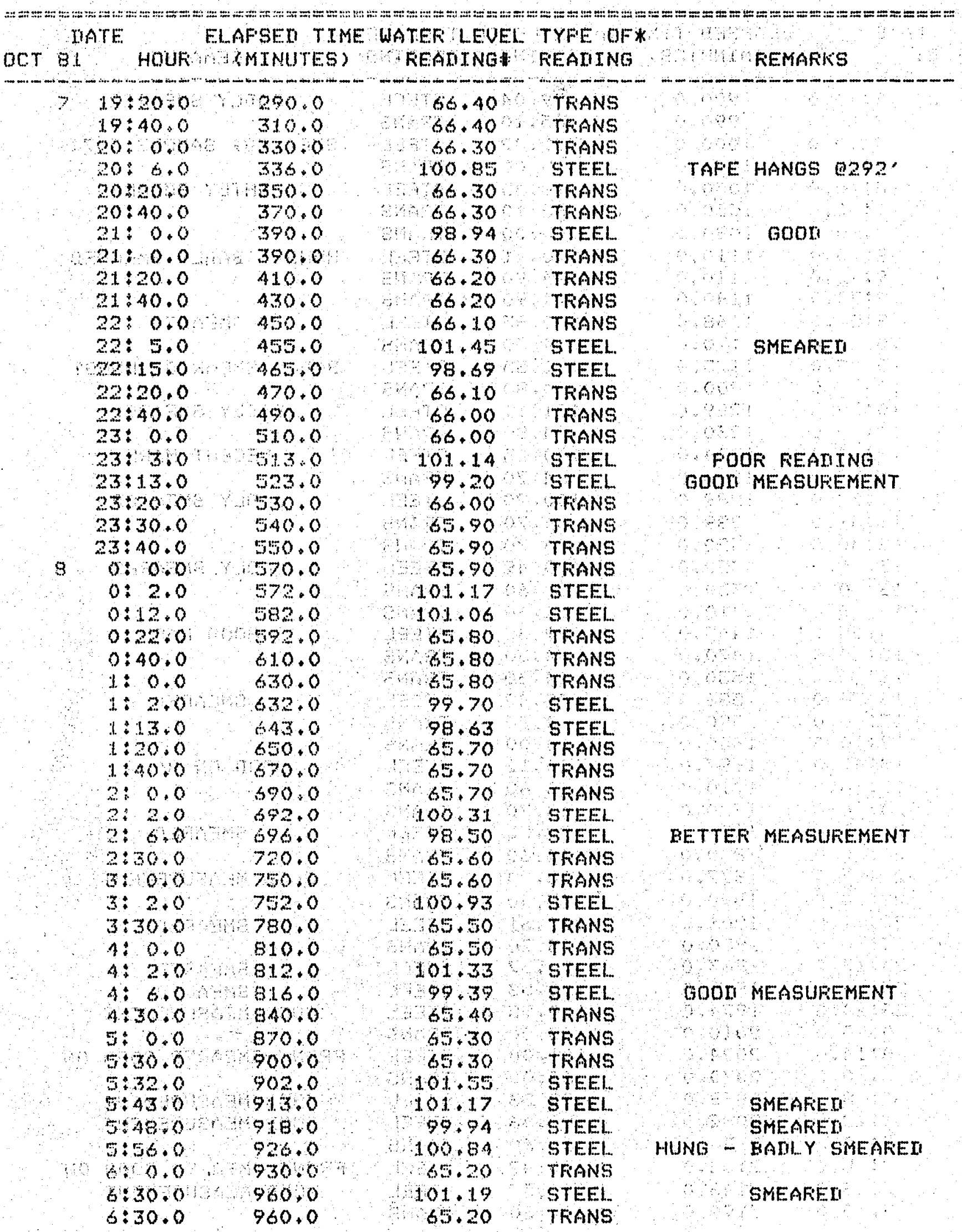


TABLE D-2. (continued)

Campbe11 ot al. \#2 pump test - water level datis

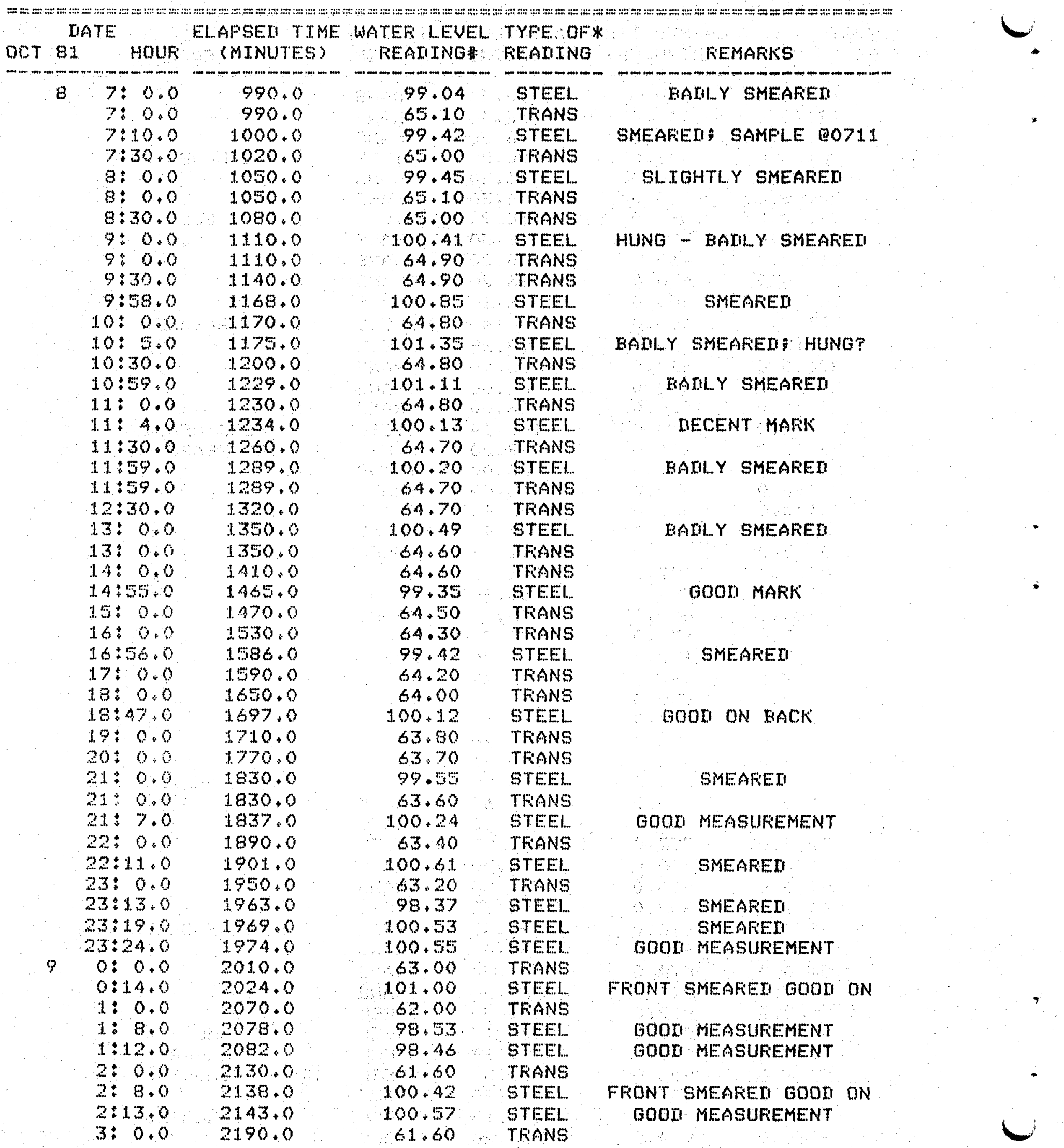


TABLE D-2. (continued)

Campral et a1. 2 pump test - water Ievel data

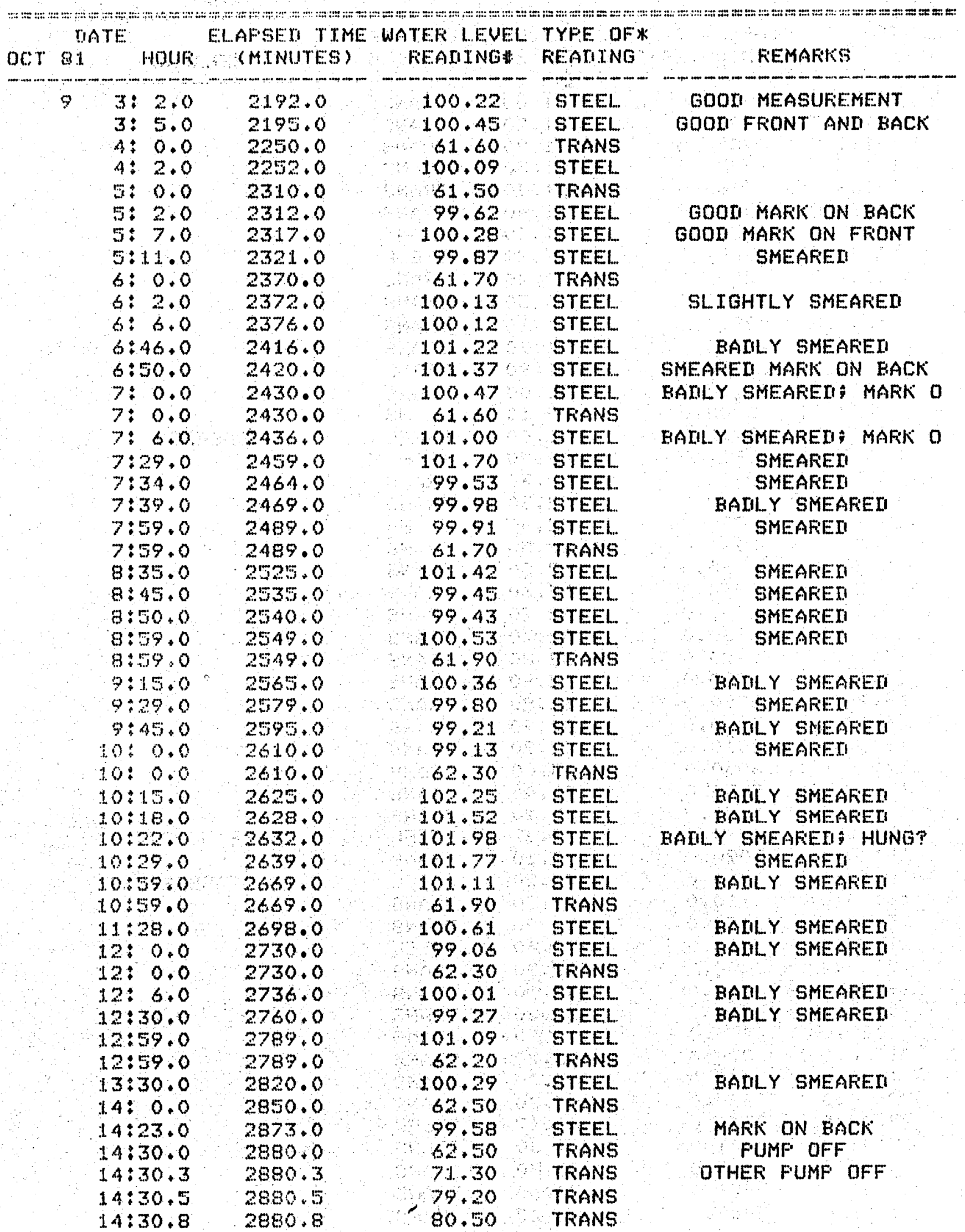

$127 \quad 65$

W. K. SUMMEFS ANO ASSOCIATES Y INC. 
TABLE D-2. (continued)

Camble11 et al. 2 rumr test - water level data

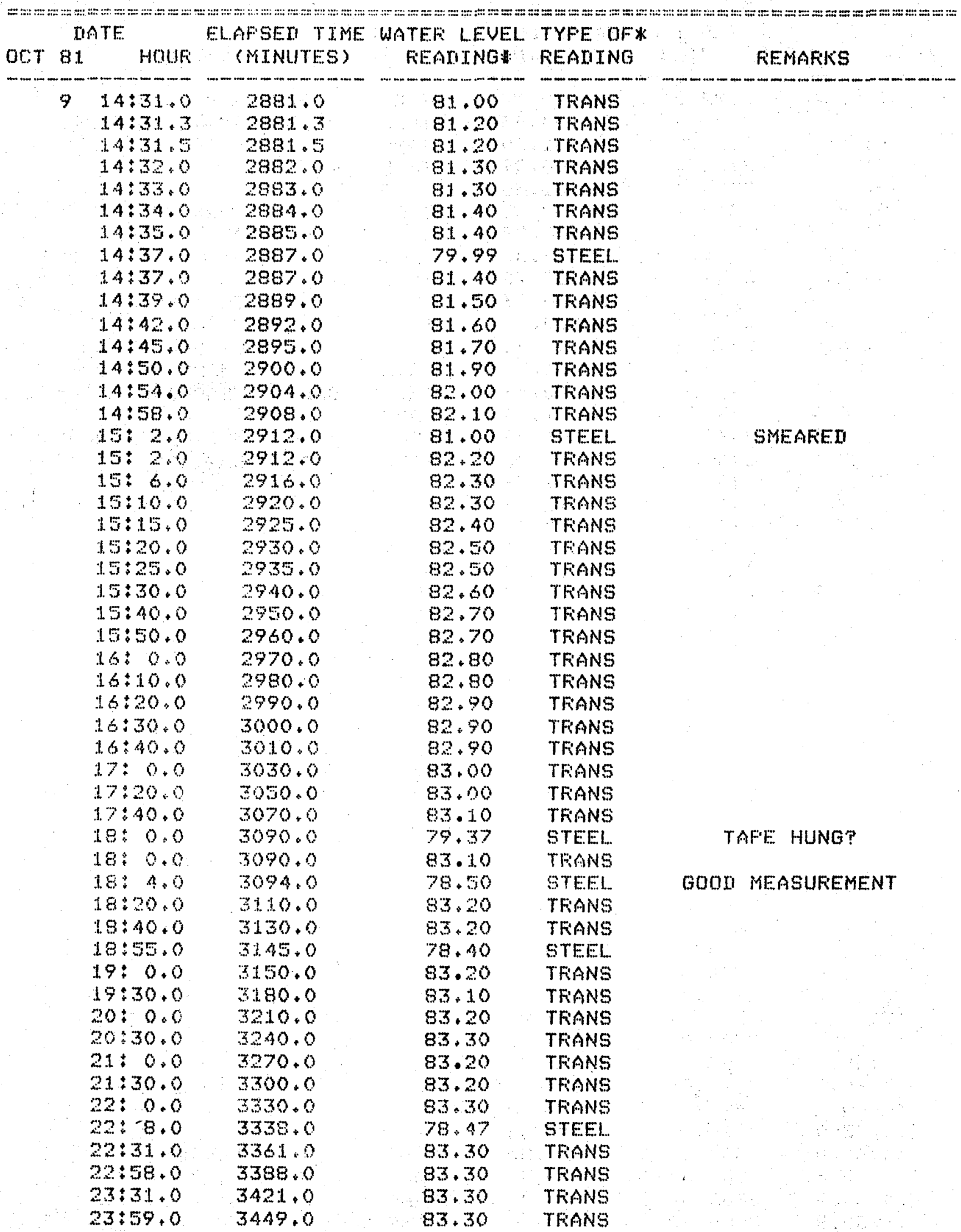


TABLE D-2. (continued)

Cample 11 ot al. H2 rum test - water leveldata

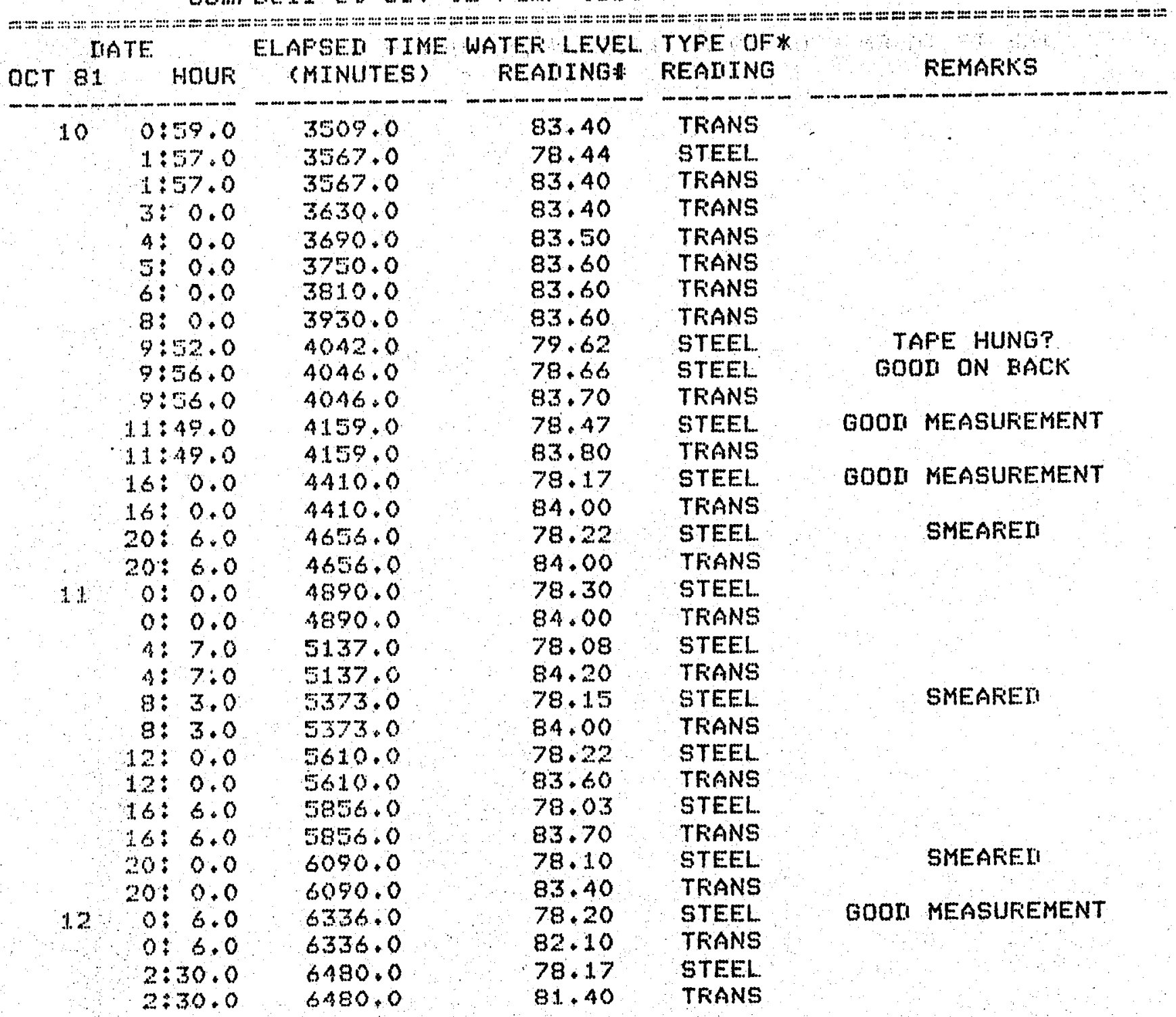

*THE TYFE OF REAUTNG RIENOTES THE TYFE OF

THEFTH TO WATEF MEASUFEMENT MATE + THESE MAY

BE ANY OF THE FOLLOWTNG:

TFANS= MEASUREMENT MATE RY A TFANSIUCEF IN THE WELL.

THE MEASUFEMENT IS THE HETGHT OF THE WATER COLUMN

ABOUE THE SENSOF.

STEEL :- MEASUREMENT MATE BY A STEEL TAFE.

AIS:- MEASUFEMENT MARE BY AN ATRLINE.

ATFTRAN MEASUFEMENT MATE BY AN AIFLINE COUFLEN WTTH A

TFANSTUCER .

ELECT $=$ MEASUREMENT MADE BY AN ELECTFIC TAFE.

AESOL =: ALL MEASUREMENTS HAVE REEN CHANGEY TO AESOLUTE IIEFTHTO-WATER MEASUFEMENTS.

WTHE WATEF LEUEL FEATING IS THE INSTRUMENT FEAIING 
TABLE D-2. (continued)

MAIE TO FINI THE DEETH TO WATER.

ELAFSEI TIME IS TAKEN FFOM TO AT 1430 ON 7 - OCT - 81

W. K. SUMMEFS ANI ASSOCTATES, INC. 
APPENDIX D

TABLE D-3.

Campbel1 et a1. H2 pum test-defth towater

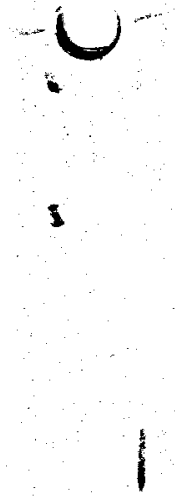

\begin{tabular}{|c|c|c|c|c|c|c|}
\hline \multicolumn{3}{|c|}{ NATE } & $\begin{array}{l}\text { ELAFSEM TIME } \\
\text { (MINUTES) }\end{array}$ & $\begin{array}{l}\text { MEFTH TOA } \\
\text { WATER (FT) }\end{array}$ & $\begin{array}{l}\text { TYPE QF* } \\
\text { FEAIIING }\end{array}$ & FEMARKS \\
\hline & 7 & 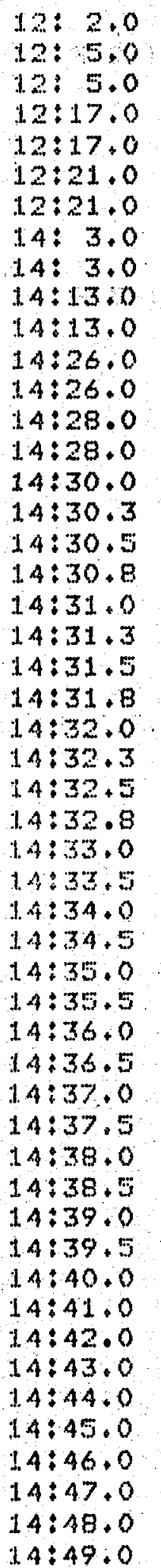 & 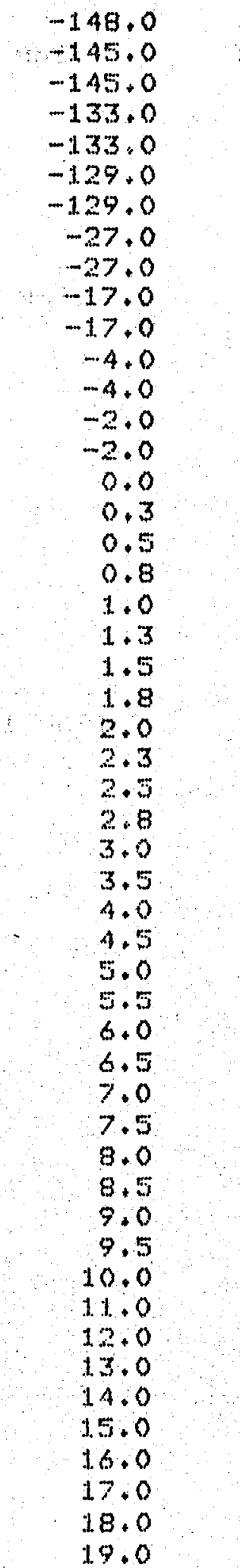 & $\begin{array}{r}75.83 \\
78.10 \\
76.73 \\
79.92 \\
77.72 \\
78.13 \\
77.72 \\
77.97 \\
77.54 \\
77.96 \\
77.53 \\
77.95 \\
77.52 \\
77.97 \\
77.52 \\
77.52 \\
86.32 \\
91.12 \\
93.61 \\
93.11 \\
96.01 \\
96.51 \\
96.81 \\
97.01 \\
97.11 \\
97.11 \\
97.21 \\
97.21 \\
97.21 \\
97.31 \\
97.31 \\
97.31 \\
97.31 \\
97.41 \\
97.41 \\
97.41 \\
97.51 \\
97.51 \\
96.61 \\
97.61 \\
97.61 \\
97.61 \\
96.21 \\
97.41 \\
97.81 \\
97.90 \\
97.90 \\
97.90 \\
98.00 \\
98.00 \\
98.10\end{array}$ & 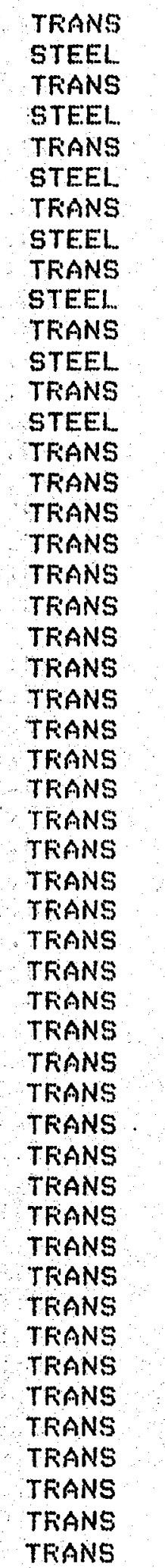 & $\begin{array}{l}\text { SLIGHTLY SMEAREI } \\
\text { FUMF TURNEN ON }\end{array}$ \\
\hline
\end{tabular}


TABLE D-3. (continued)

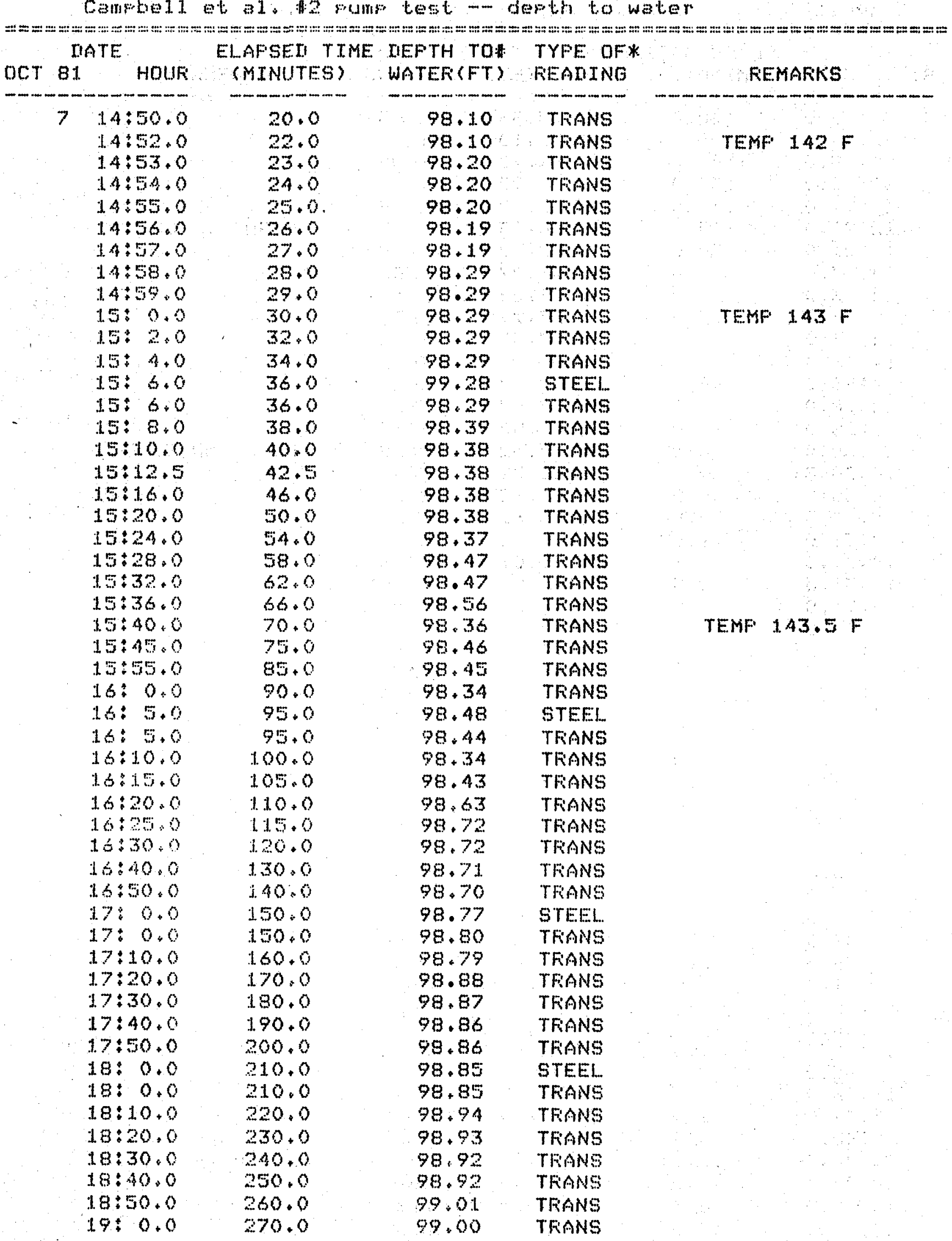


TABLE D-3. (continued)

Campbell et al. N2 pump test - depth to water

-2)

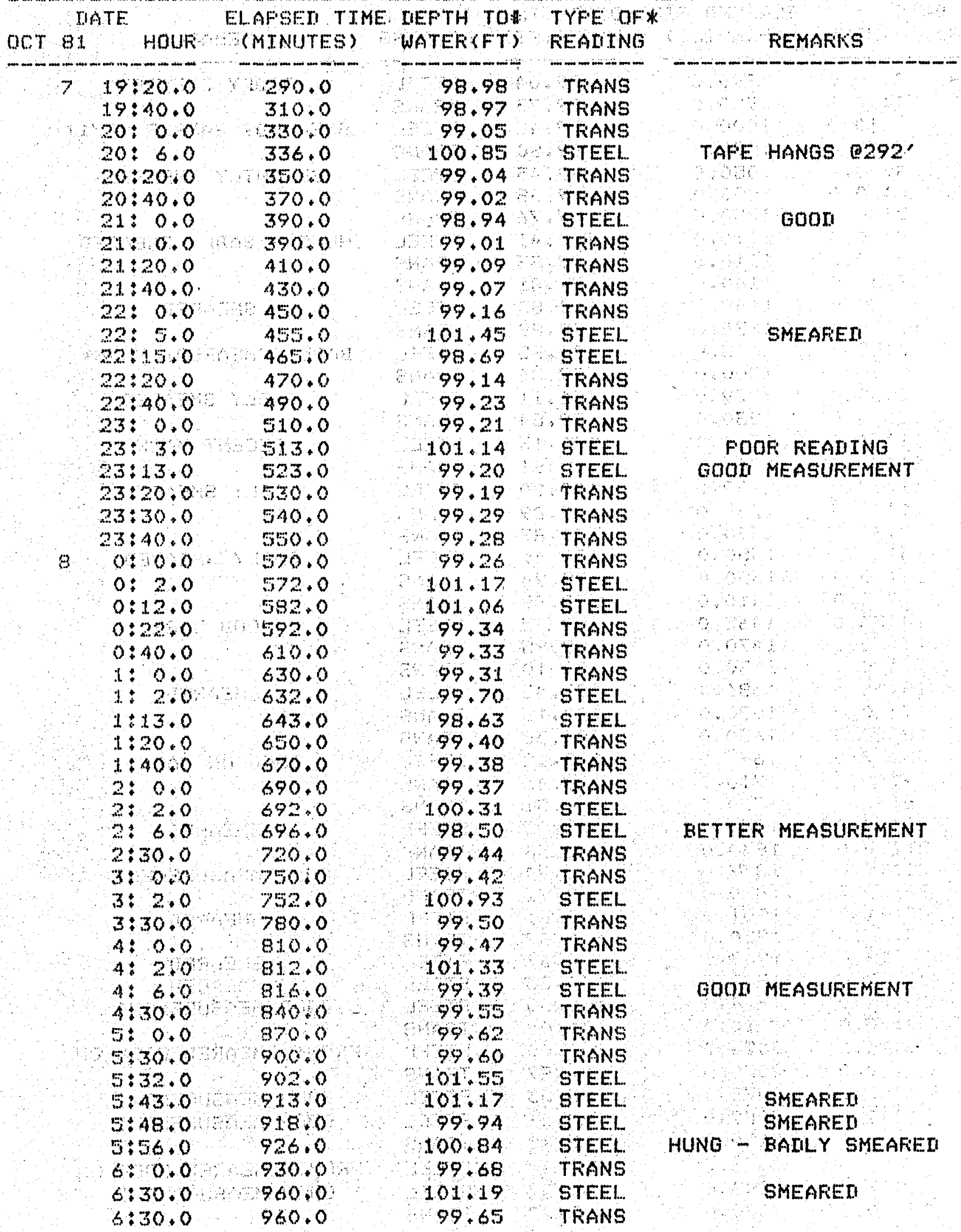


TABLE D-3. (continued)

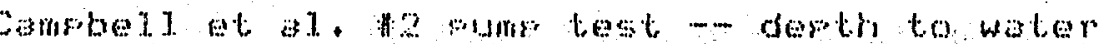

OCT 8.1 HOUF

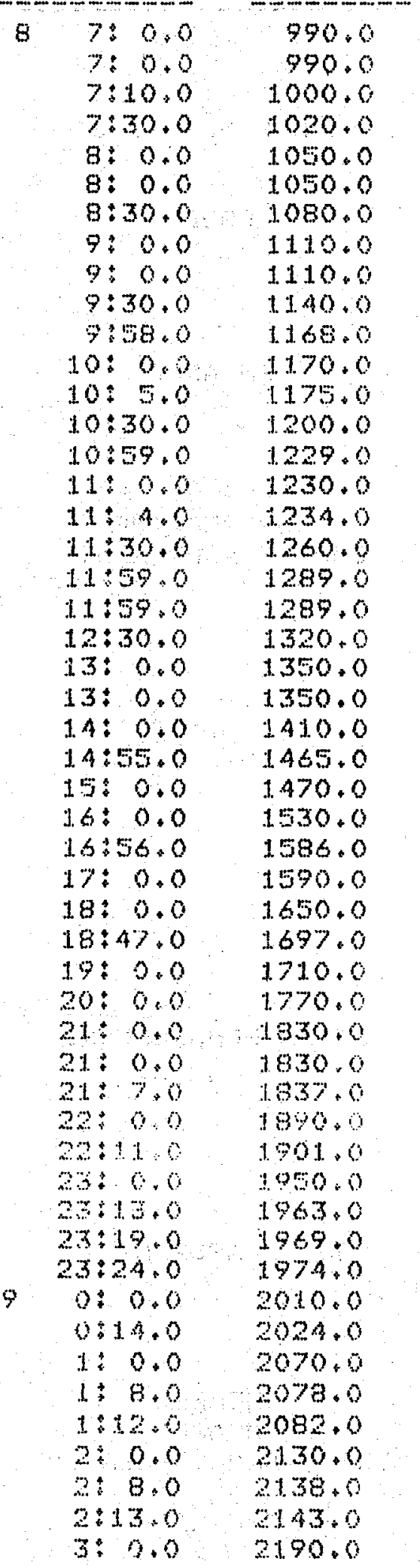

ELAFSET TIME IIEFTH TOU TYFE OF* (MINUTES) WATEF(FT) FEALTNG

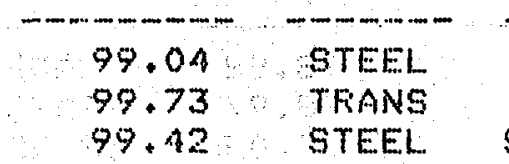

99.80 TFANS

99.45 STEEL.

99.68 TRANS

$99.76:$ TFANS

100.41 STEEL

99.83 TRANS

99.81 $\therefore$ TFANS

100.85 , STEEL.

99.89 TFANS

$101.35 \quad$ STEEL.

99.86 TFANS

$101+11$ STEEL.

99.84 TFIANS

100.13 STEEL.

99.91 TRANS

100.20 : STEEL..

$99.89 \because \quad$ TRANS

99.87 TFANS

100.49 STEEI.

99.94 TFANS

99.89 TRANS

99.35 STEEL

.99 .95 TFANS

100.10 TFANS

99.42 . STEEL

LOO.15 TFANS

100.30 TRANS

$100.12 \quad$ STEEL

109.46 TFANS

100.51 TFANS

$99.5 \%$ STEEL

100.56 TrANS

100.24 STEEI.

100.7 THANS

$100.6 \%$ STEEI..

100.87 TRANS

98.37 STEEI

100.53 STEEL

100.55 STEEL

101.02 TRANE

101.00 STEEL

101.97 TFANS

98.53 STEEL

98,46 STEEL

102,32 TFANS

$100+92$ STEEL

$100+57$

$162+2 \%$
REMAFIIS

EAMILY SMEAREN

SMEARED SAMFLE R0711

SL TGHTLY SMEAREN

HUNG - BARLY SMEAFEN

SMEARED

BAILY SMEAFELY HUNG?

EARLY SMEAFED

DECENT MARK

BAIILY SMEAFEI

WADI..Y SMEAREI

GOON MAFK

SMEAREI

DOON ON BACK

SMEAFEN

OOOD MEASUFEMENT

SMEAFEN

SMEAREI

SMEAFET

GOON MEASUFEMENT

FRONT SMEAREI GOON ON

GOONI MEASUFEMENT

GOON MEASUREMENT

FFONT SMEAFED GOOI ON GOOD MEASUREMENT

\section{4}


TABLE D-3. (continued)

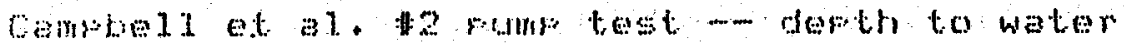

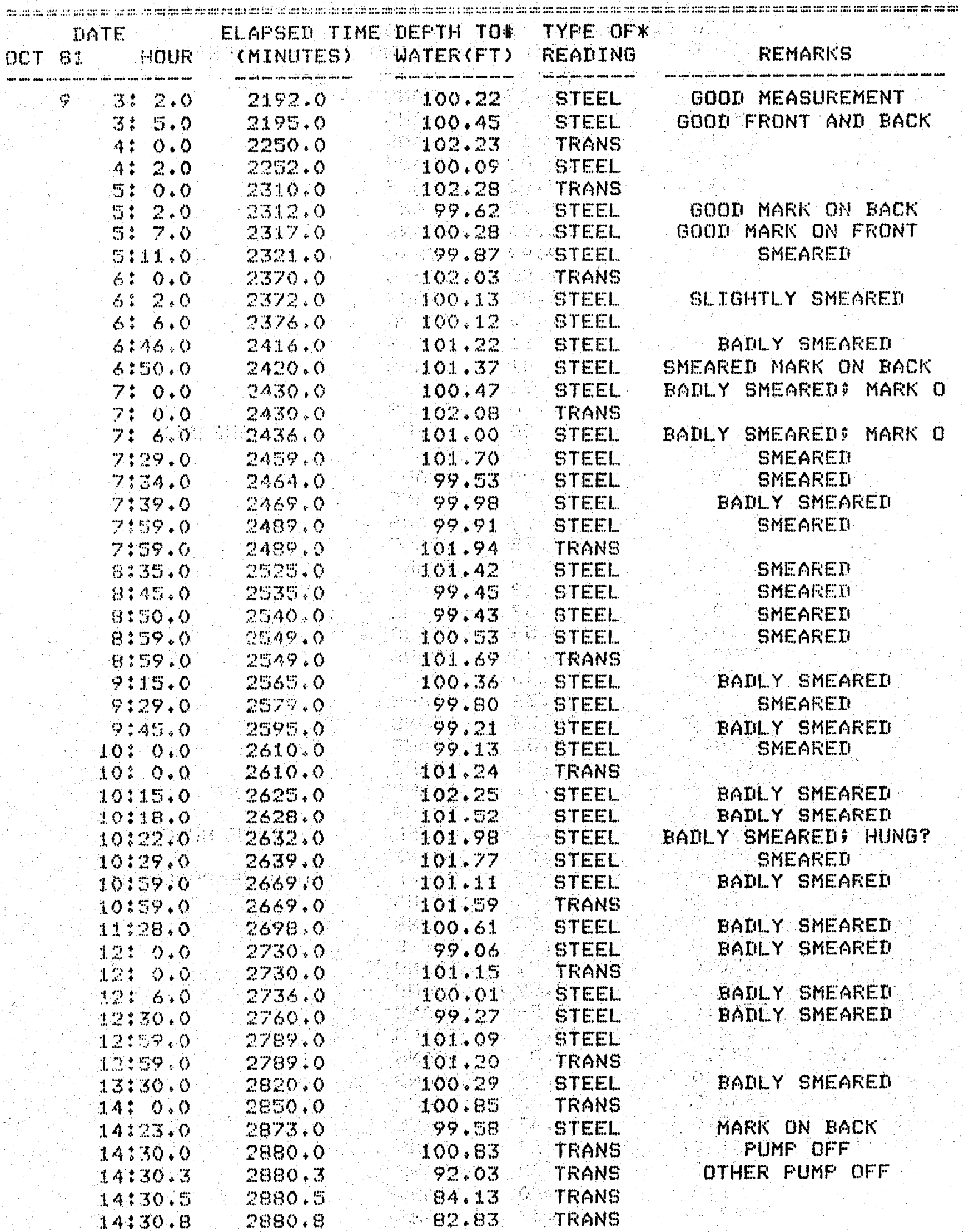


TABLE D-3. (continued)

Comprell et al. H2 pum test -o. desth to water

\begin{tabular}{|c|c|c|c|c|c|}
\hline & TATE & ELAFSEY TIME & IIEFTH TON: & TYFE OF* & \\
\hline OCT & HOUF: & MINUTES & WATEF(FT) & FEAIING & FEMAFKS \\
\hline$--m$ & (n) & . & . & $-m--m-m$ & $\cdots+\cdots+\cdots$ \\
\hline & $14: 31.0$ & 2891.0 & 82.33 & TFANS & \\
\hline & $14: 31 \cdot 3$ & $2801+3$ & 82.12 & TFANS & \\
\hline & $14 \div 31 \cdot 5$ & $2881 \cdot 5$ & 82.12 & TFANS & 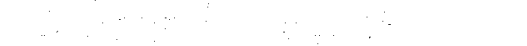 \\
\hline & $14: 32+0$ & $2882 \cdot 0$ & 82.02 & TFANS & \\
\hline & $14: 3,3.0$ & 2883.0 & 82.02 & TFANS & \\
\hline & $14: 34,0$ & 2884.0 & 81.92 & TFIANS & \\
\hline & $14: 35 \cdot 0$ & $2885+0$ & 81.92 & TFANS & \\
\hline & $14: 37.0$ & 2897.0 & 79.99 & STEEL. & \\
\hline & $14: 37.0$ & $\because 88 \% .0$ & 81.92 & TFANS & $\because$ \\
\hline & $14: 39,0$ & 2889.0 & 81.82 & TFANS & \\
\hline & $14: 42 \cdot 0$ & $2892 \cdot 0$ & 81.72 & TFANS & \\
\hline & $14: 4: 0$ & $2890+0$ & $81 \cdot 61$ & TFANS & \\
\hline & $14: 50 \cdot 0$ & $2900 \cdot 0$ & 81.41 & THANS & \\
\hline & $1.4 \$ 5.0$ & 2904.0 & 81.31 & TFANS & $\therefore$ \\
\hline & $14 \div 58 \cdot 2$ & 2908.0 & 81.20 & TFAMS & $\therefore$ \\
\hline & $15: 2.0$ & 2912.0 & 81.00 & STEEL & SMEAFEI \\
\hline & $15: 200$ & 2912.0 & $81 \cdot 10$ & TRANS & 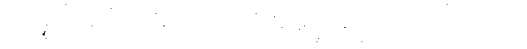 \\
\hline & $15 \% 6.0$ & 2916.0 & 81.00 & TFANS & : \\
\hline & $15: 10: 0$ & 2920.0 & 80.99 & TFANS &.$\quad \therefore$ \\
\hline & $15+15.0$ & 2925.0 & 80.89 & TFANS & \\
\hline ' & $10: 20 \cdot 0$ & 2930.0 & 80.79 & TFANS & \\
\hline & $16+25: 0$ & 2935.0 & 80.78 & TFANS & \\
\hline & $1: \div 30 \cdot 0$ & 2940.0 & $80+68$ & TFANS & \\
\hline & $15 \pm 40,0$ & 2950.0 & 80.57 & TFANS & \\
\hline & $15: 50,0$ & $2960 \cdot 0$ & 80.56 & TFANS & \\
\hline & $16 * 0.0$ & 2970.0 & 80.45 & TFANS & \\
\hline & $16 \div 10.0$ & 2980.0 & 80.45 & TFANS & $\therefore$ \\
\hline & $16 \div 20.0$ & $2990+0$ & 80.34 & TFANS & \\
\hline & $\begin{array}{l}1630+0 \\
16: 40.0\end{array}$ & $\begin{array}{l}3000.0 \\
3010.0\end{array}$ & $\begin{array}{l}80.33 \\
80.32\end{array}$ & $\begin{array}{l}\text { TFANS } \\
\text { TFANS }\end{array}$ & \\
\hline & $.7: 0.0$ & 3030.0 & $80+21$ & TFANS & \\
\hline & $17: 20 \cdot 0$ & 3050.0 & 80.19 & TFANS & \\
\hline & $1 \% \div 40,0$ & 3070.0 & $80+0 \%$ & TFANS & \\
\hline & $16: 0.0$ & 3090.0 & $79+37$ & SIEEL & TAFE HUNG? \\
\hline & $19 \div 0.0$ & 3090.0 & 80.06 & TFANS & 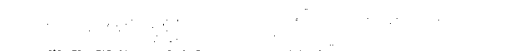 \\
\hline & $\mathrm{LB}+4 \cdot 0$ & 3094.0 & $78: 50$ & STEEI & GOOI MEASUFEMENT \\
\hline & $18: 20 \cdot 0$ & 3110.0 & 79.94 & TFANS & \\
\hline & $18: 40.0$ & $3130+0$ & 79.93 & TFANS & \\
\hline & 1. $8: 55-9$ & $3445+0$ & 78.40 & STEEL & $\therefore$ \\
\hline & $19: 0.0$ & 3150.0 & 79.91 & TFANS & \\
\hline & $19: 30: 0$ & 3180.0 & 79.99 & TFANS & \\
\hline & $20: 0.0$ & $3210+0$ & 79.86 & TFANS & \\
\hline & $20 \div 30.0$ & 3240.0 & $79+74$ & TFIANS & \\
\hline & $21 \div 0.0$ & $3270+0$ & 79.82 & TFANS & \\
\hline & $21: 30.0$ & 3300.0 & 79.79 & TFANS & \\
\hline & $22 \div 0.0$ & 3.330 .0 & 79.67 & TFANS & - \\
\hline & $22: 8.0$ & 3338.0 & $78+47$ & STEEL & $\therefore \quad \therefore$ \\
\hline & $22 \div 31 \cdot 0$ & 3331.0 & 79.64 & TFANS & \\
\hline & $22: 58 \rightarrow 0$ & 3388.0 & 79.62 & TFIANS & 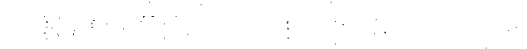 \\
\hline & $23: 31.0$ & 3421.0 & 79.60 & TFANS & \\
\hline & $23: 69+0$ & 34.49 .0 & 79.97 & TFANS & \\
\hline
\end{tabular}

\section{6}


TABLE D-3. (continued)

Cambel1 ot al, ta sumetest - berth to water

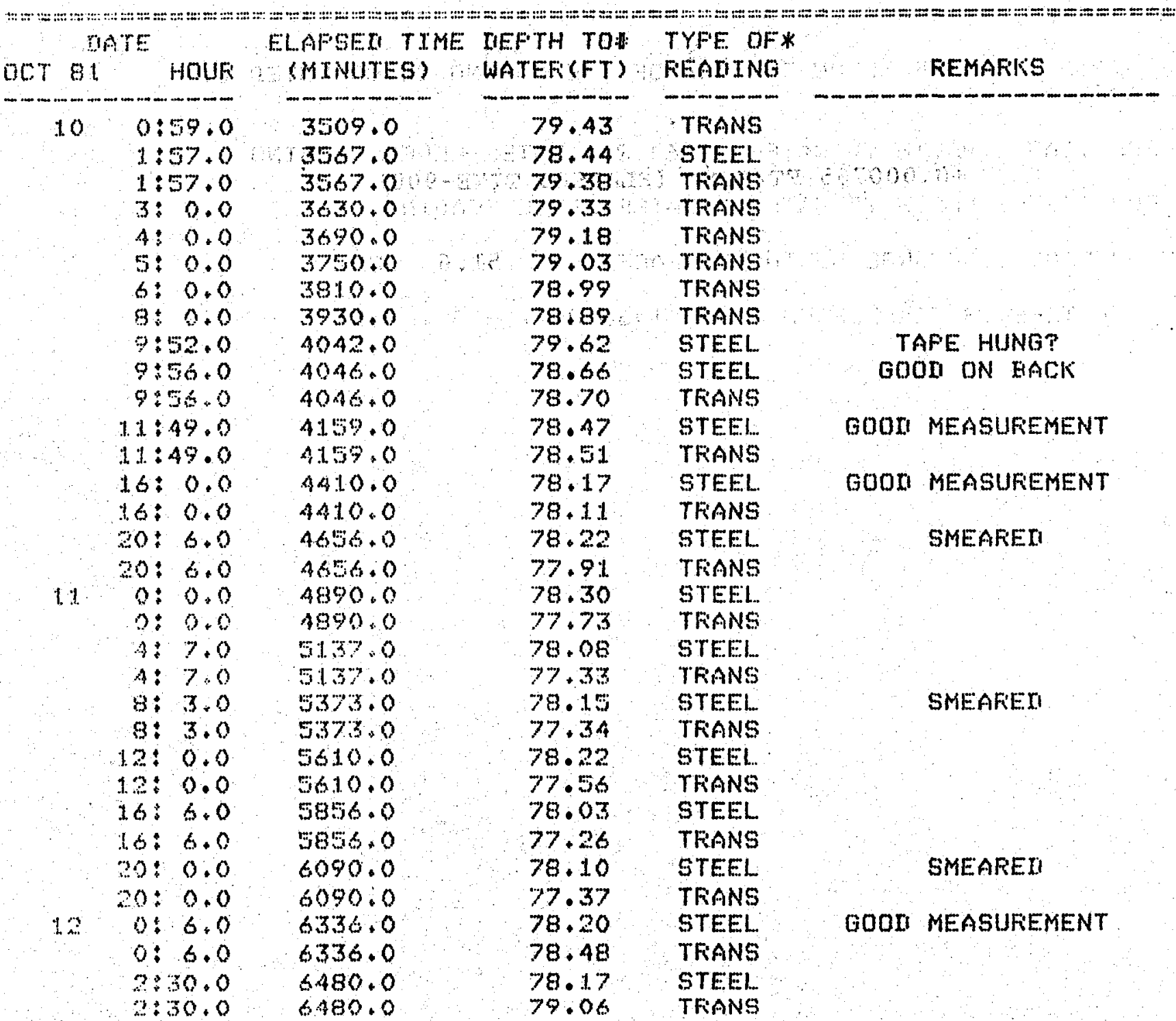

*THE TYFE OF FEAIING DENOTES THE TYFE OF

DEFTH TO WATEF MEASUFEMENT MATIE, THESE MAY

BE ANY OF THE FOLLOWTNG:

TRANS:- MEASUFEMENT MAIE BY A TRANSTUCEF IN THE WELL. THE MEASUREMENT IS THE HEIGHT OF THE WATER COLUMN ABOUE THE SENSOF,

STEEL MEASUREMENT MAIE BY A STEEL TAFE.

AIR - MEASUFEMENT MAIE BY AN AIFLINE.

AIRTFAN=MEASUREMENT MATE BY AN AIFILINE COUFLEI WITH A TRANSIUUCEFI.

EIECT = MEASUFEMENT MAIE EY AN ELECTFIC TAFE.

ABSOL = ALL MEASUREMENTS HAUE REEN CHANGEI TO ABSOLUTE DEFTHTO-WATER MEASUFEMENTS.

WHE TEFTH TO WATER IS THE CAL CULATEI DEFTH TO WATER 


\section{TABLE D-3. (continued)}

FFOM THE TOF OF THE WE L... CASTNG, .43 FEET ABOUE THE LANO SUFFACE.

THE TEFTH TO UATER EELOU THE TOF OF THE CASING IS COMFUTEO EY THE FORMULA.

FOF TFANS, DEFTH TO WATEF 164.9 - WATEF LEVEL FEATTNG $+0.000765 \mathrm{FT} / \mathrm{MIN}$ * (ELAPSED TIME-900)

FOF STEEL, IEFTH TO WATEF = WATEF LEVEI FEAIING

THE AUEFAGE TISCHAFGE RURING FUMFAGE IS 51.6 GFM.

ELAPBEI TIME IS TAKEN FFOM TO AT 1430 ON 7 - OCT - 81 


\section{APPENDIX D}

TABLE D-4.

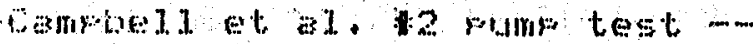

calculated adousted time, Harriliss arsument, drawdowry erecific orawdown $(s / a)$ and swecife drawdown adjusted for Jacob's correction $\left(s^{\prime} / a\right)$

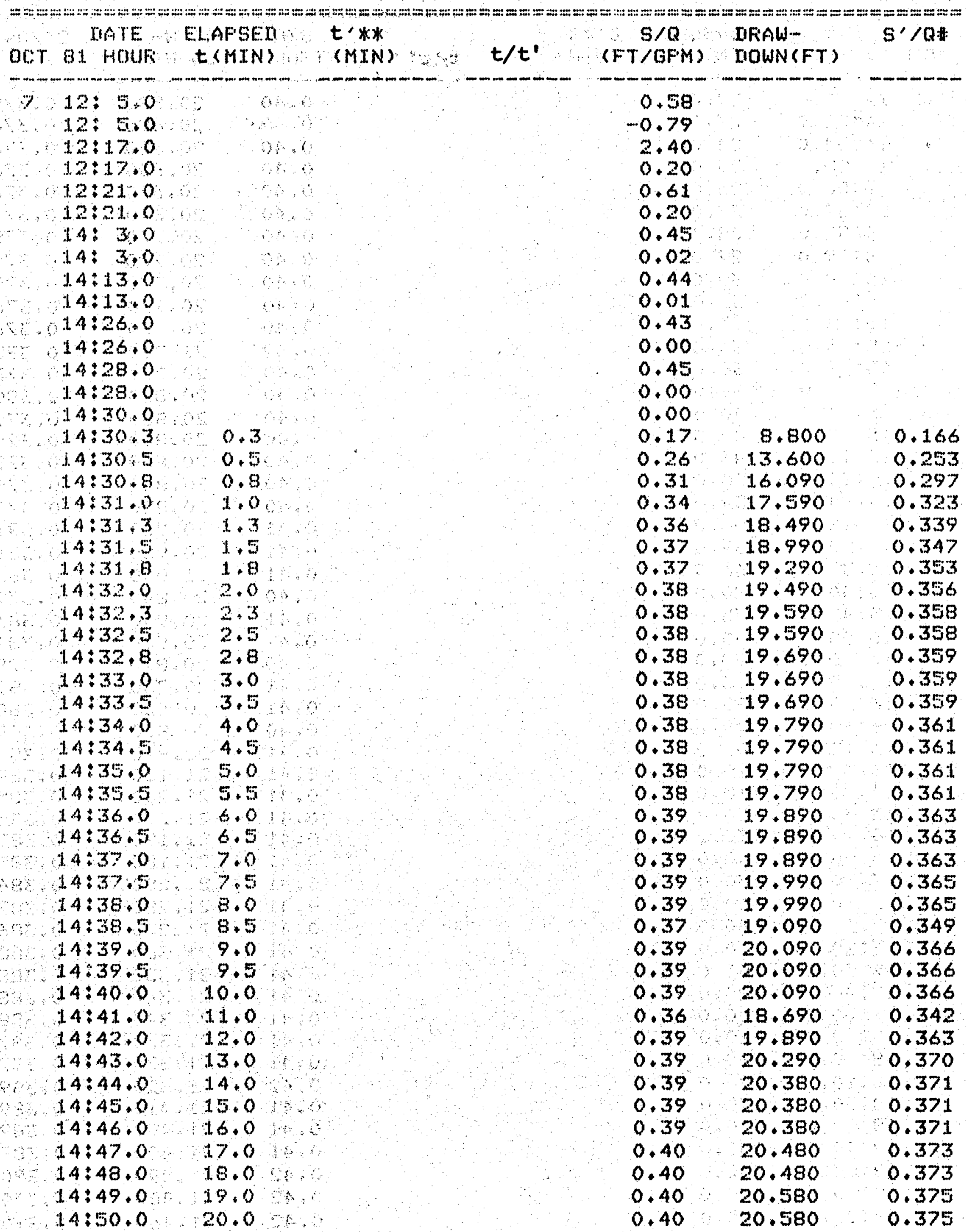


TABLE D-4. (continued)

Campbel1 et a1. H2 mum test -

calculated adjusted time, Harrill's arsument, drawdown specific drawGowr ( $s / a)$ end specific drawdown adjusted for Jacob's correction (s'/a)

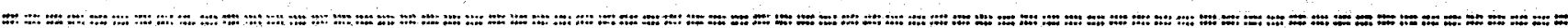

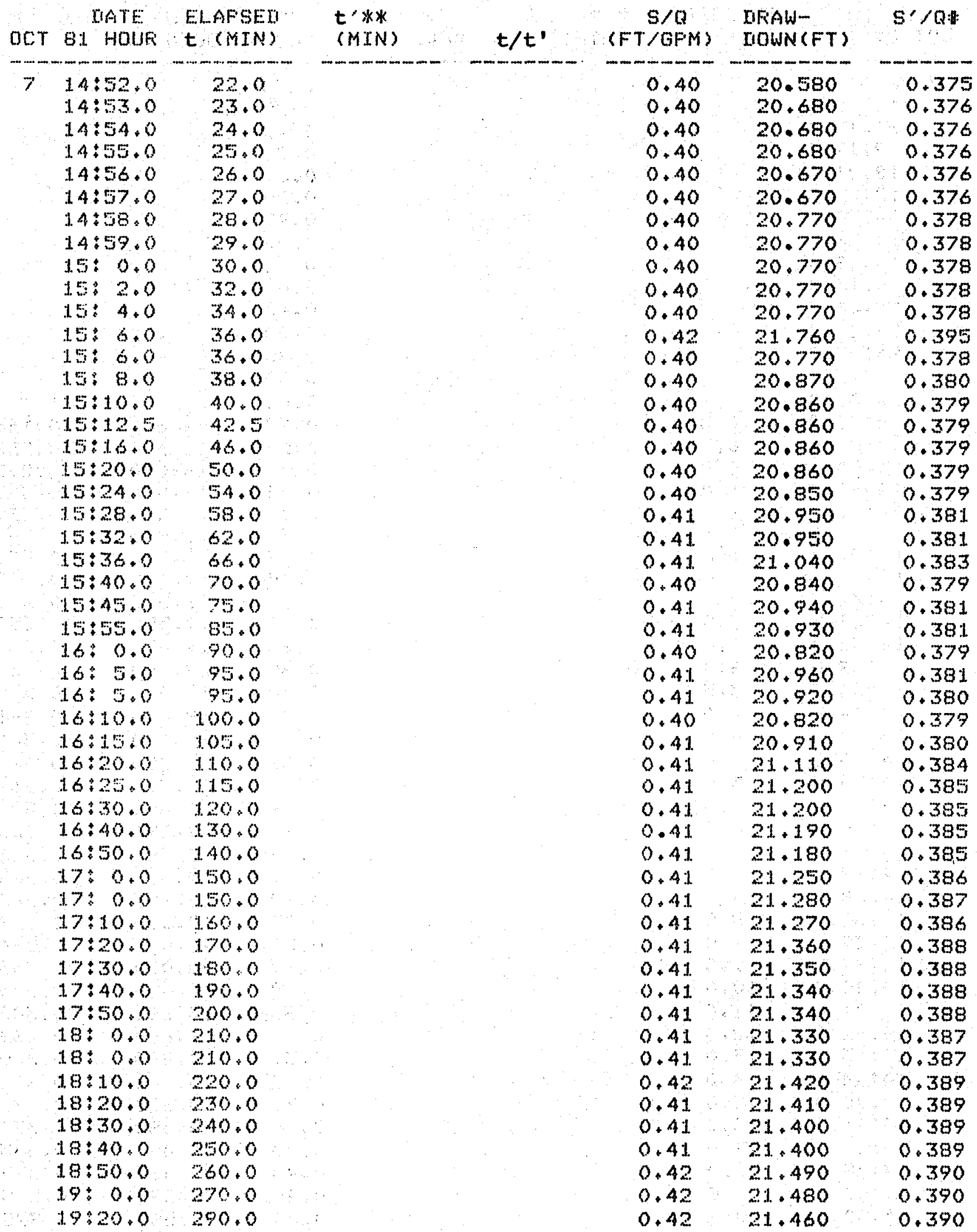


TABLE D-4. (continued)

CampbeI et 31 . H2 grimis test

calculated aduisted time, Harril1's arsumerit, drawdown, sfecific drawdown (e/C) ard specific drawdown adjusted for Jacob's correction (s'/a)

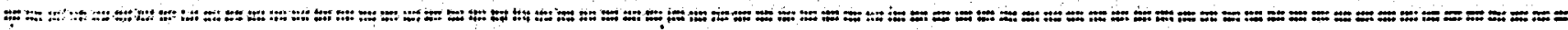

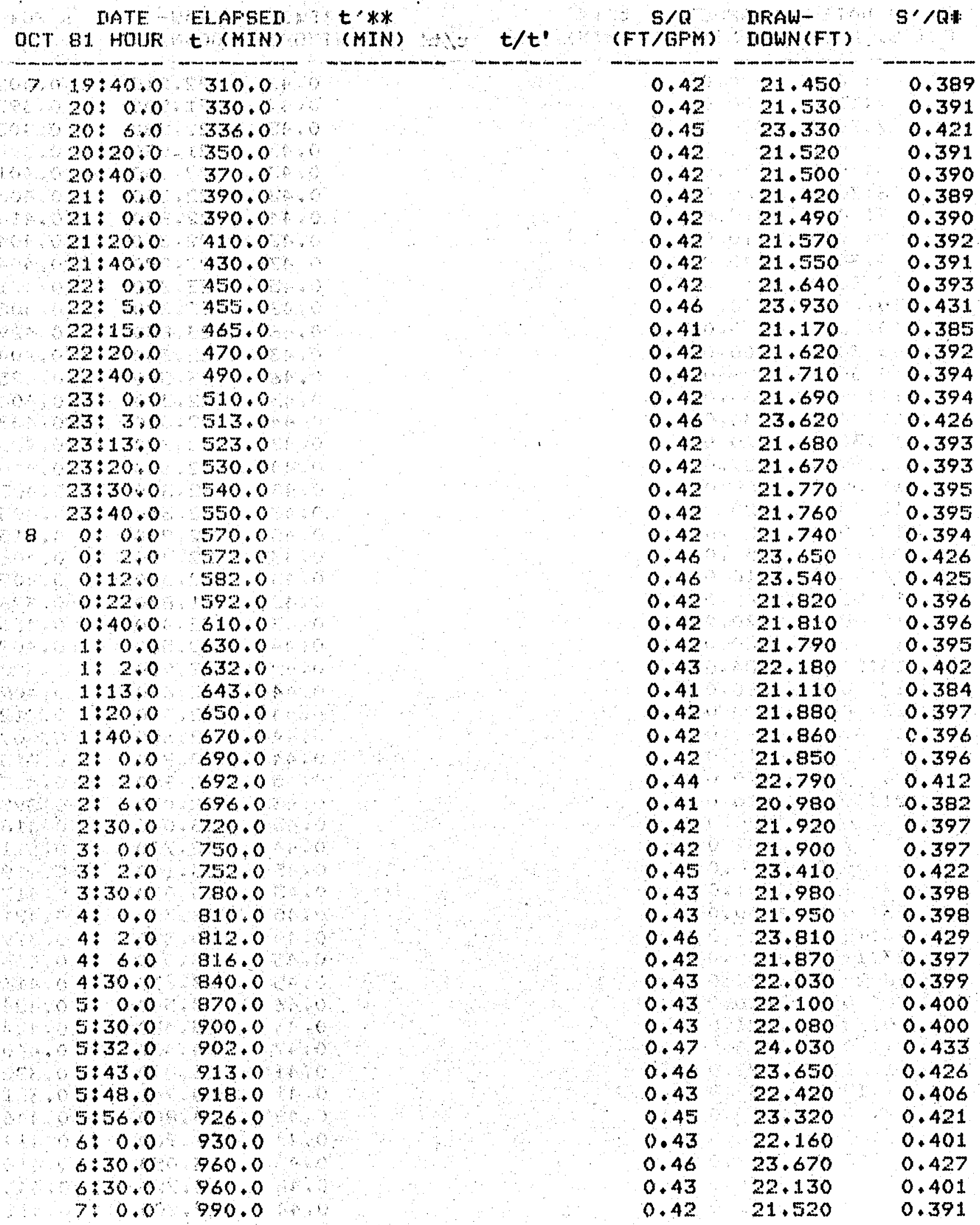


TABLE D-4. (continued)

Campbel1 et a1. H2 rums test--

calculated adjutad lime. Harrili's arsument, drawdown, specific draw-

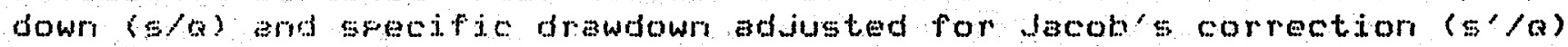
J

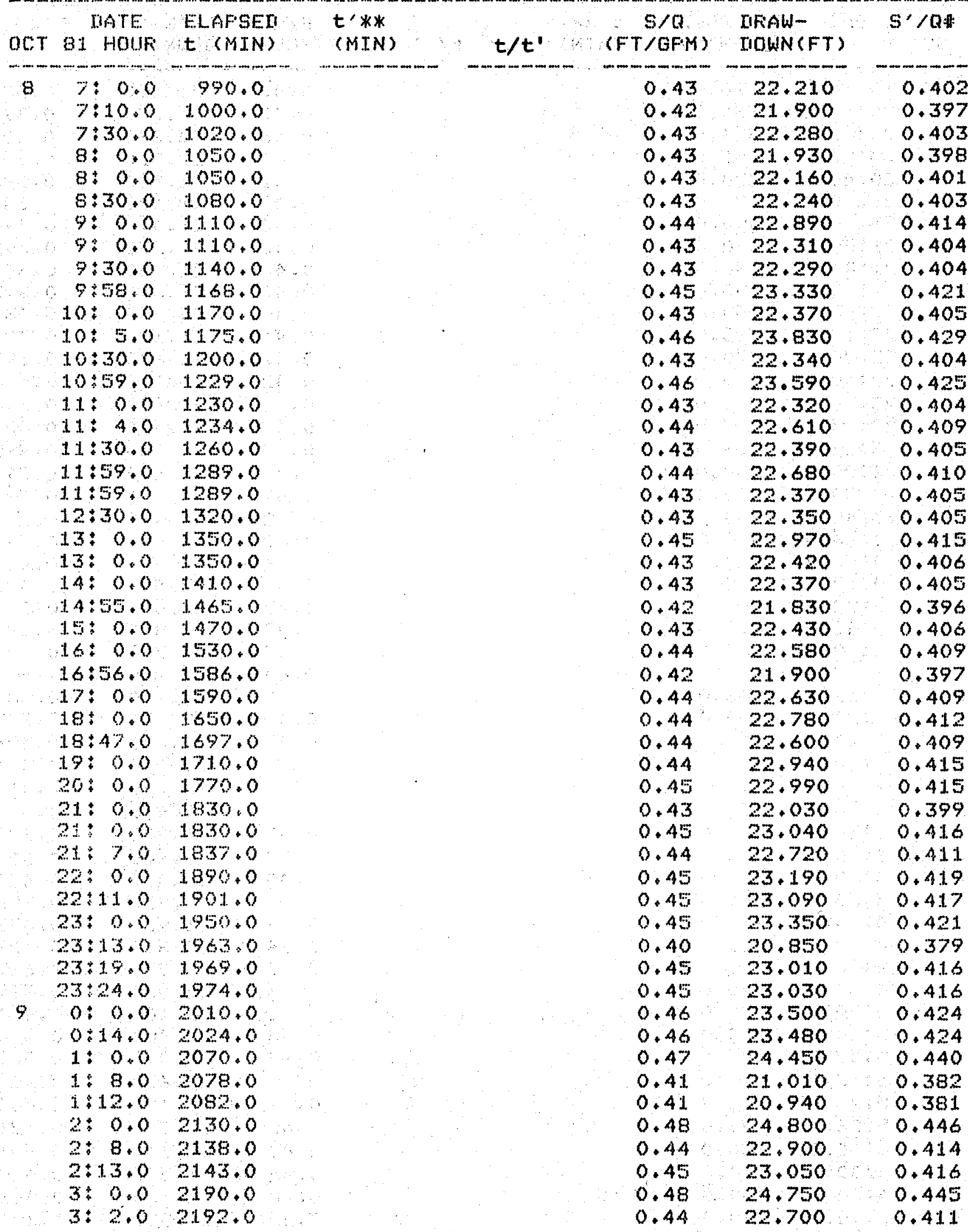


TABLE D-4. (continued) bell et B1. 2 pum test--

calculated adbuted time. Harrili's arsumerit drawdown, specific drawtowri (s/a) and specticic drawdowr abusted for Jacob!s correction (s'/a)

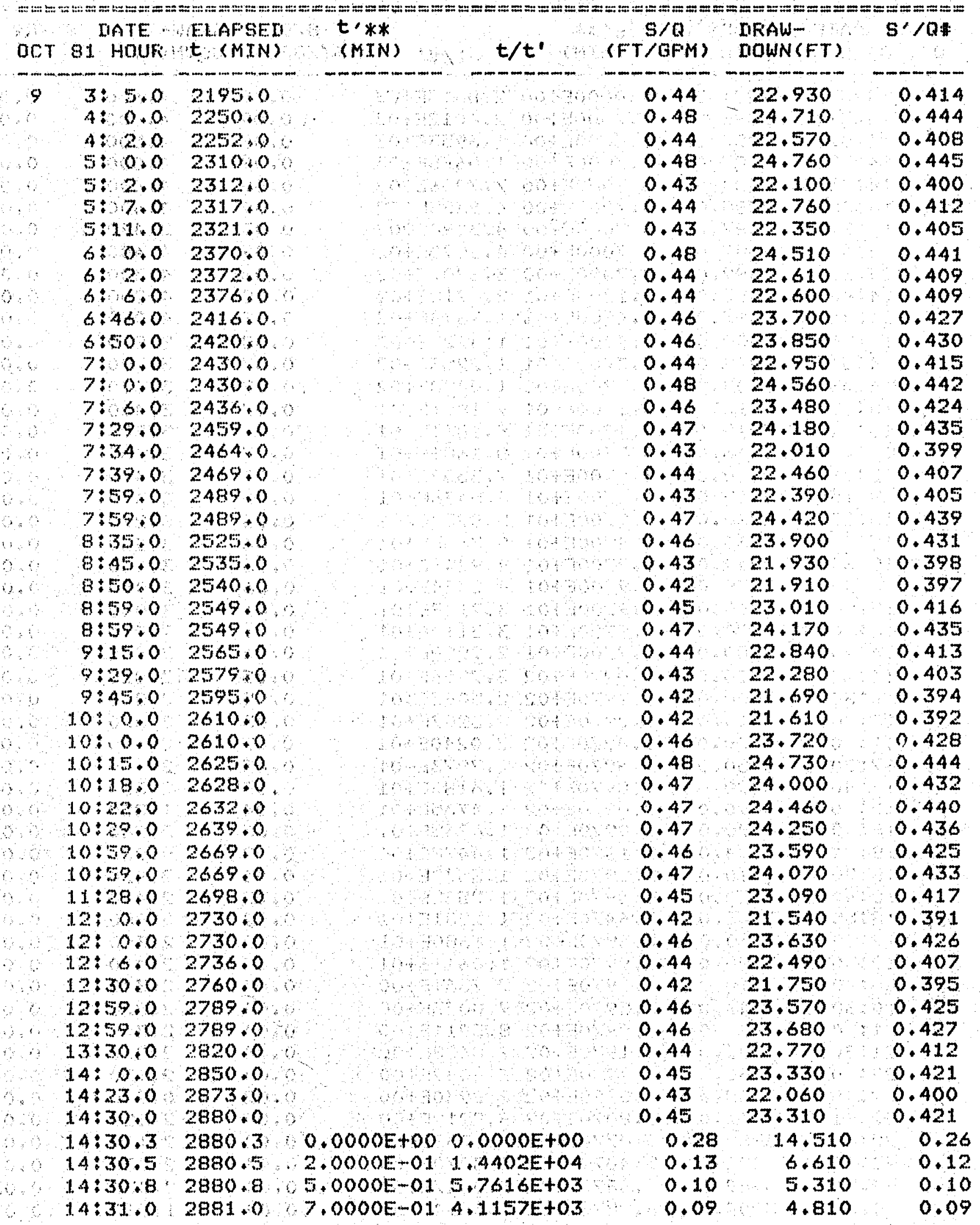


TABLE D-4. (continued)

Camprol1 et al. N2 pump test -

calculated adjusted time Harril1!s arsument, drawdown, specific drawdown ( $s / Q$ ) arid specific drawdown adjusted for Jacob's correction ( ${ }^{\prime} / Q$ )

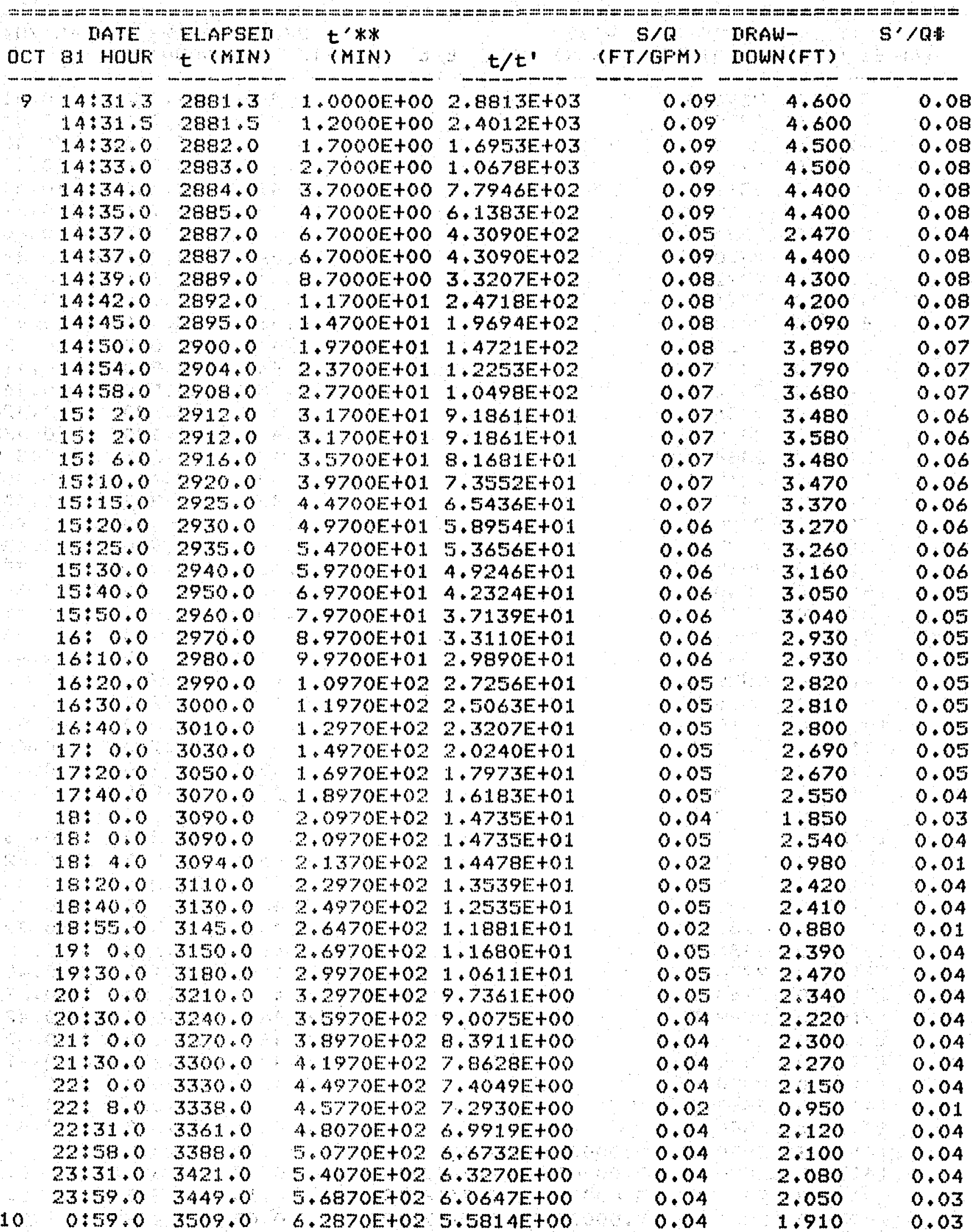


TABLE D-4. (continued)

Campoll et al. 2 fium test -

calculated adjusted time. Harrijl's arsument. drawdown' sfecific drawdown ( $s / a)$ arrd specific drawdown adjusted for Jacob's correction $\left(s^{\prime} /(a)\right.$

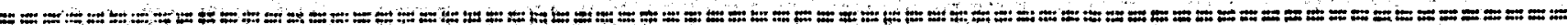

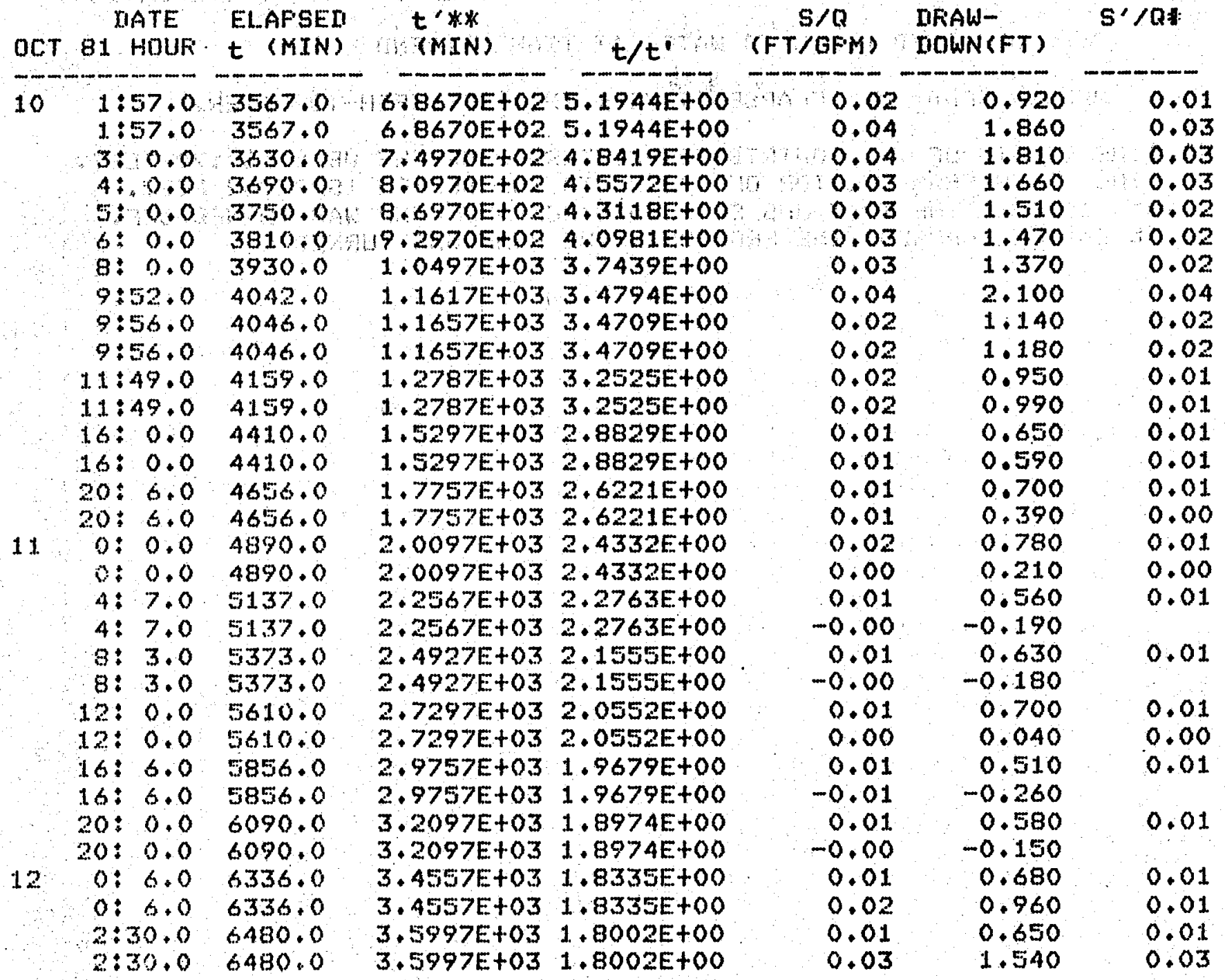


TABLE D-4. (continued)

\# $5^{\prime}$ IS THE JACOE COFFECTION, $S^{\prime}=5-5 * 2 / 20$.

THE IRAWIOWN $S$ AT ELAFSEI TIME T IS CALCULATEII FROM THE EQUATION:

$S$ OBSEFUEI IDEPTH TO WATER AT TIME T-TRENI

WHERE TFENM= O * ELAFSEO TIME + INITIAL DEFTH-TO-WATEF.

THE LENGTH OF THE CONTRIBUTING INTEFUAL OF THE WELL IS 170 FEET.

THE DEFTH FROM THE TOF OF CASING TO THE SCREEN IS 77.52 FEET. * *t IS THE TIME THAT HAS ELAFSEI SINCE THE PUMF WAS TURNED OFF.

$t$ IS THE ELAFSEN TIME FFOM UHEN THE FUMF WAS TUFNED ON. 


\section{APPENDIX D}

TABLE D-5.

Norbh 0bseryation weII pump test - - water level data

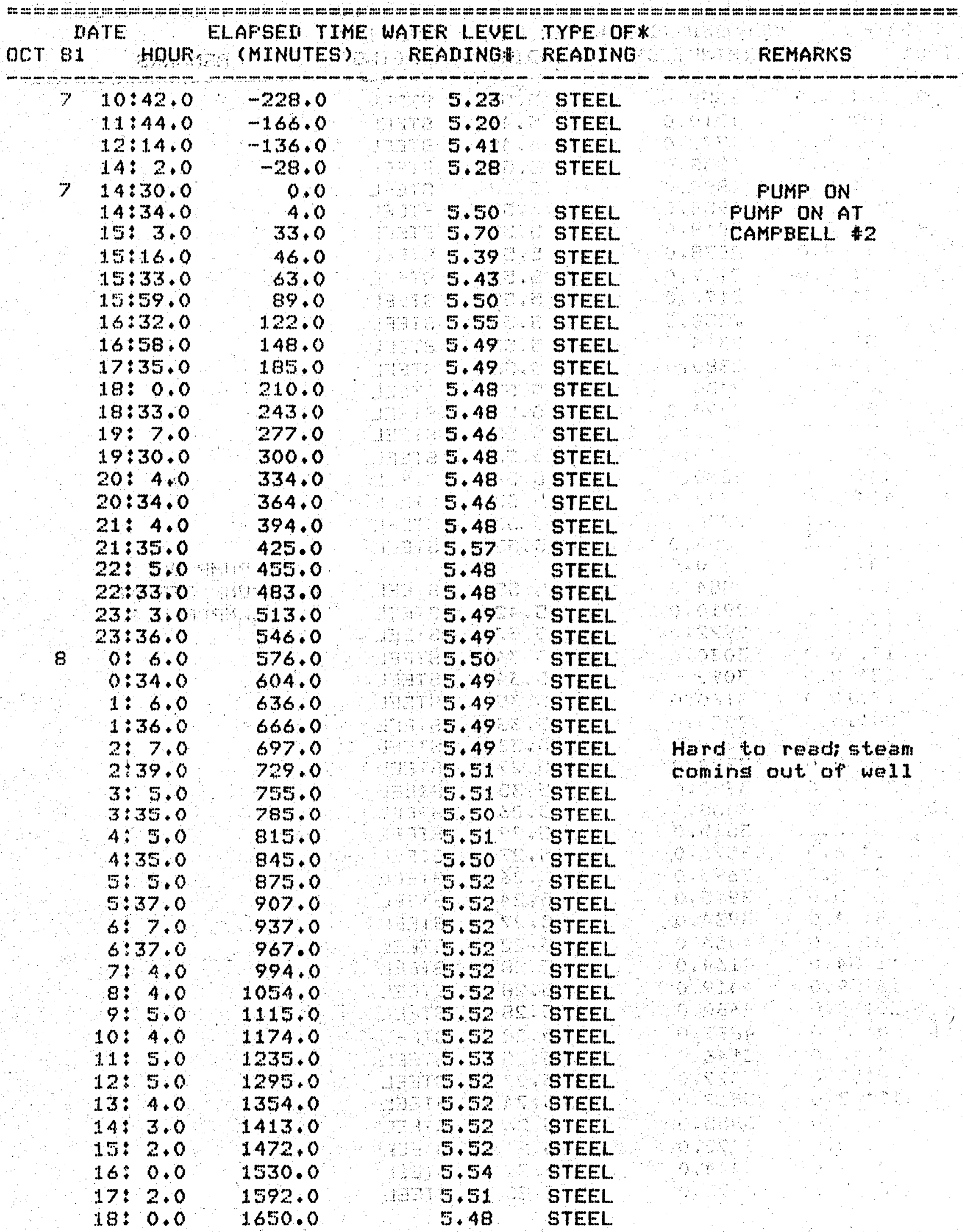


TABLE D-5. (continued)

North observation we11 pum test - water level data

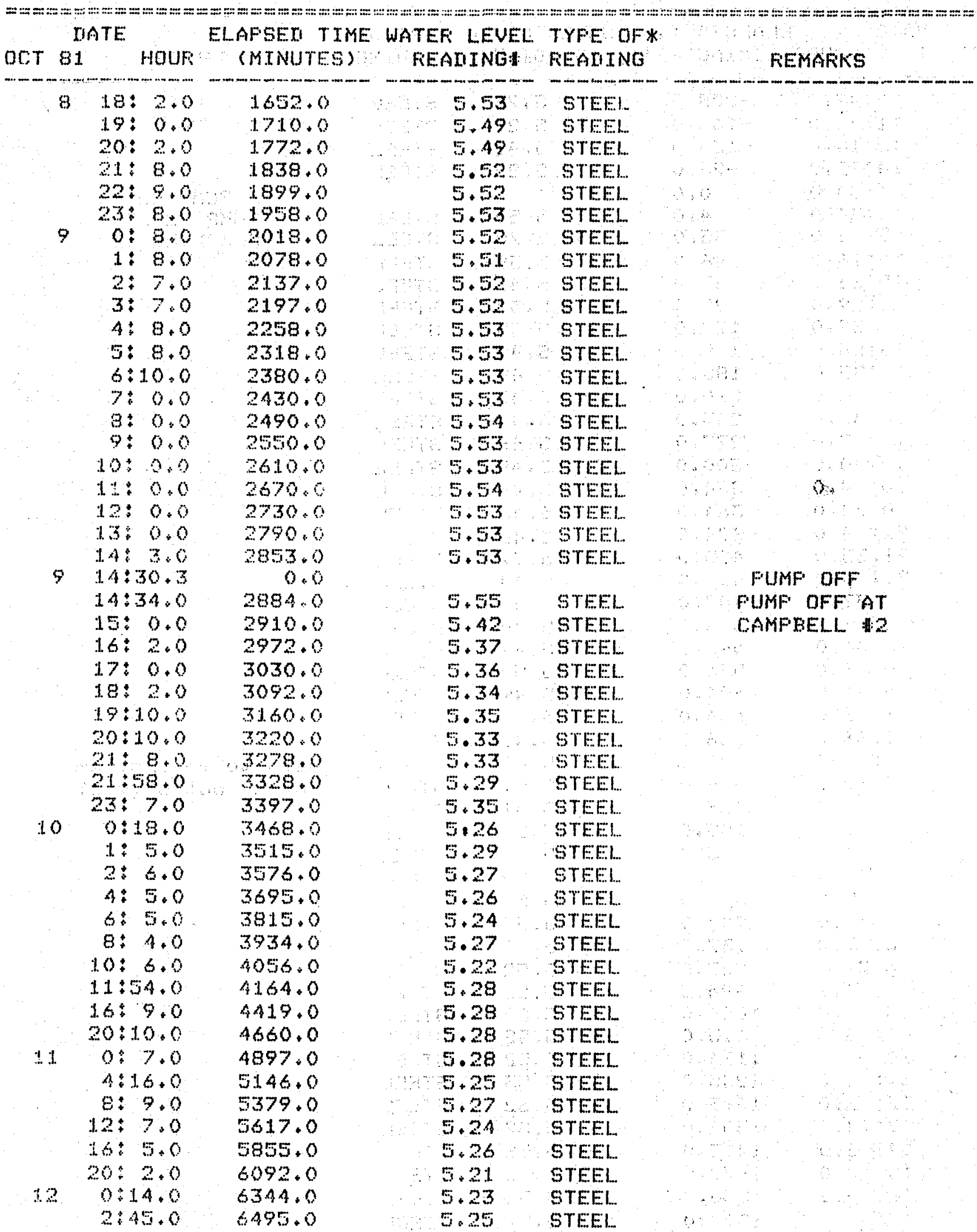


TABLE D-5. (continued)

*THE TYFE OF REAITNG IENOTES THE TYFE OF

DEFTH TO WATEF MEASUREMENT MANE. THESE MAY

BE ANY OF THE FOLLOWING:

TRANS: MEASUREMENT MAIIE BY A TFANSDUCEF IN THE WELL.

THE MEASUREMENT IS THE HETGHT OF THE WATER COLUMN AROUE THE SENSOF.

STEEL:: MEASUFEMENT MAIE BY A STEEL TAPE.

ATF:-: MEASUFEMENT MALE EY AN ATRLINE.

AIFTFAN MEASUREMENT MALE BY AN ATFLINE COUFLEO UITH A

OTRANSDUCEF.

ELECT - MEASUREMENT MAIE BY AN ELECTFIC TAFE.

ABSOL= ALL MEASUFEMENTS HAOE BEEN CHANGET TO ABSOLUTE DEFTH-TO-WATER MEASUREMENTS.

\#THE WATER LEVEL FEAIING TS THE INSTRUMENT FEAIING

MANE TO FINI THE IEFTH TO WATEF.

ELAFSEI TTME IS TAKEN FROM TO AT 1430 ON $7-$ OCT -81 


\section{APPENDIX D}

TABLE D-6.

North Observation we 11 mow test - dewth to water computations

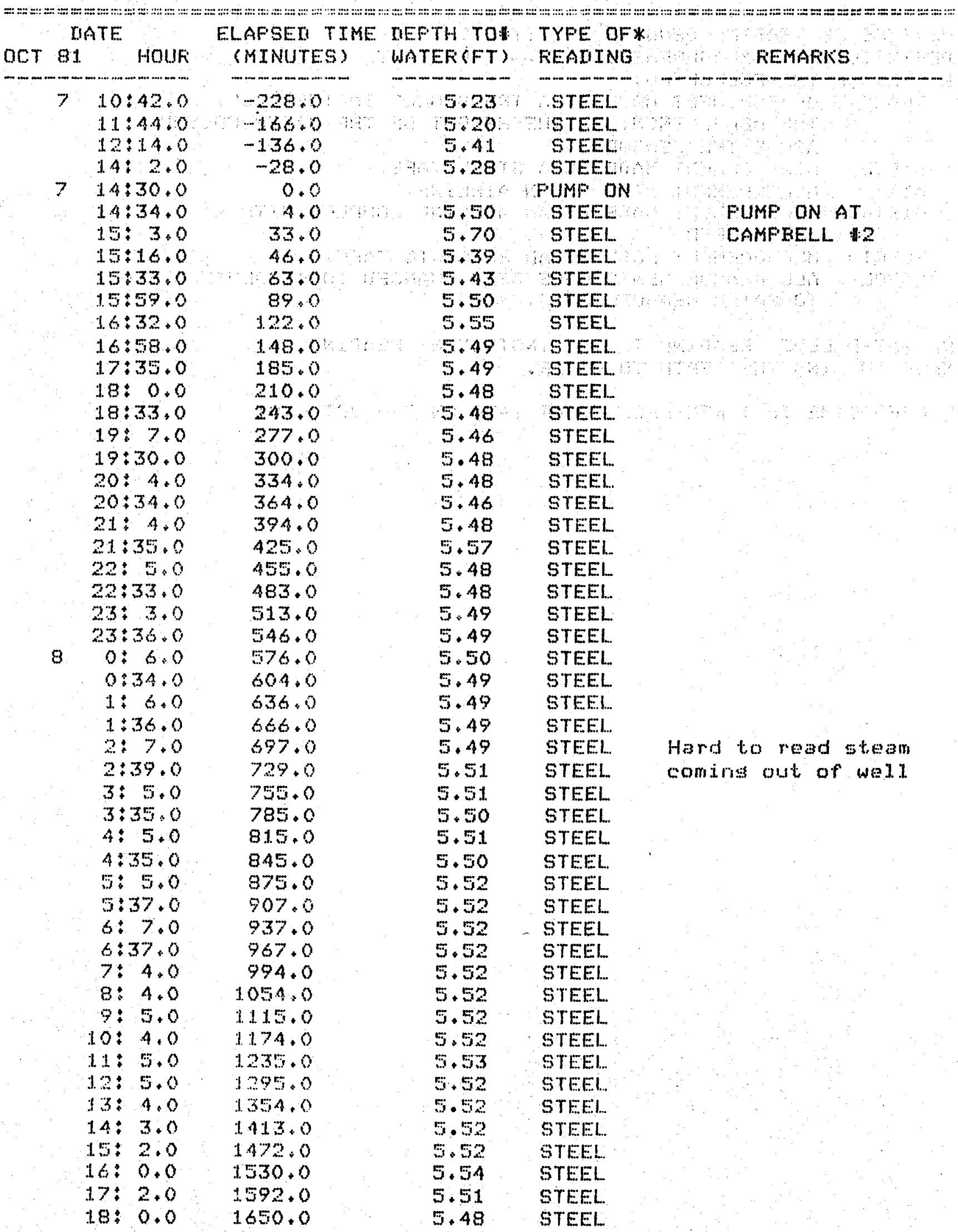


TABLE D-6. (continued)

North observation well pump test - derth to water comsutations

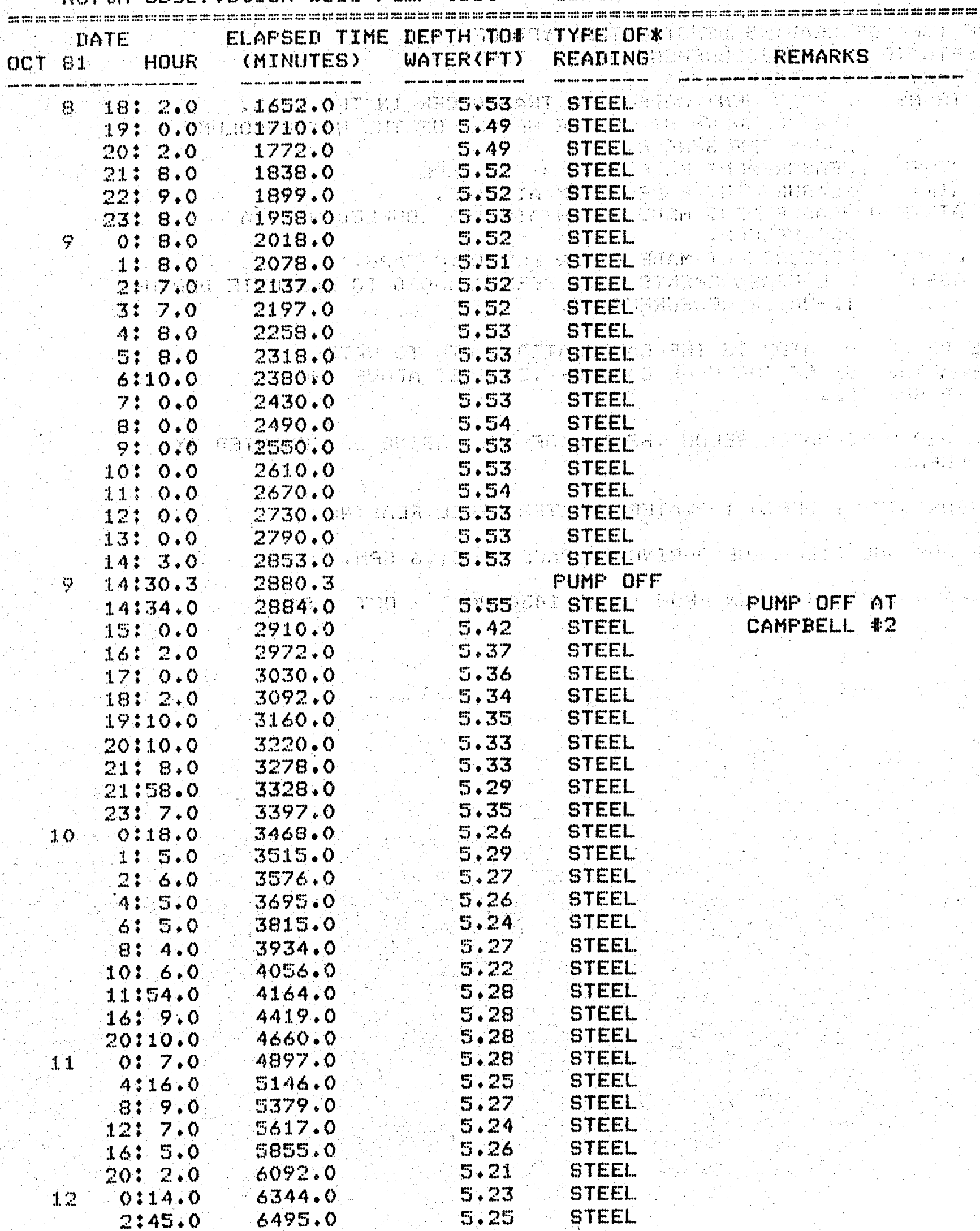


*THE TYFE OF FEAIING IIENOTES THE TYFE DF

IIEFTH TO WATER MEASUREMENT MAIE, THESE MAY

BE ANY OF THE FOLLOWTNG:

TFANS = MEASUFEMENT MATE EY A TFANSTUCEF IN THE WELL.

THE MEASUFEMENT IS THE HETGHT OF THE WATER COLUMN

STEEI $=$ ABOVE THE SENSOF, MSUFEMENT MAIE RY A STEEL TAFE.

AIR:- MEASUFEMENT MAIIE BY AN AIRLTNE.

AIFTRAN =MEASUREMENT MALE BY AN AIFLTNE COUFLEO WITH A TFANSTUCER.

ELECT $=$ MEASUREMENT MALE BY AN ELECTRTC TAFE.

AESOL $=$ ALL MEASUFEMENTS HAVE BEEN CHANGED TO AESOLUTE IIEFTHTO-WATEF MEASUREMENTS.

*THE DEFTH TO WATER IS THE CALCULATEII DEFTH TO WATEF

FROM THE TOF OF THE WELL CASTNG, 35 FEET ABOUE THE

LAND SUFFACE.

THE IIEFTH TO WATEF BELOW THE TDF OF THE CASING IS COMFUTEN EY THE FOFIMULA,

FOF STEEL, IEFTH TO WATER = WATEF LEUEL FEAMING

THE AUEFAGE IISCHARGE DURING FUMFAGE IS 51.6 GFM.

ELAFSEI TIME IS TAKEN FROM TO AT 1430 ON 7 - OCT - 81 


\section{APPENDIX D}

TABLE D-7. $\quad$ North Dbservation well pump test calculated adjusted time, Harrill's arsumert, drawdown, sfecific drawdown $(s / Q)$ and specific drawdownaduluted for Jacob's correction ( $\left.s^{\prime} / Q\right)$ $=2=$

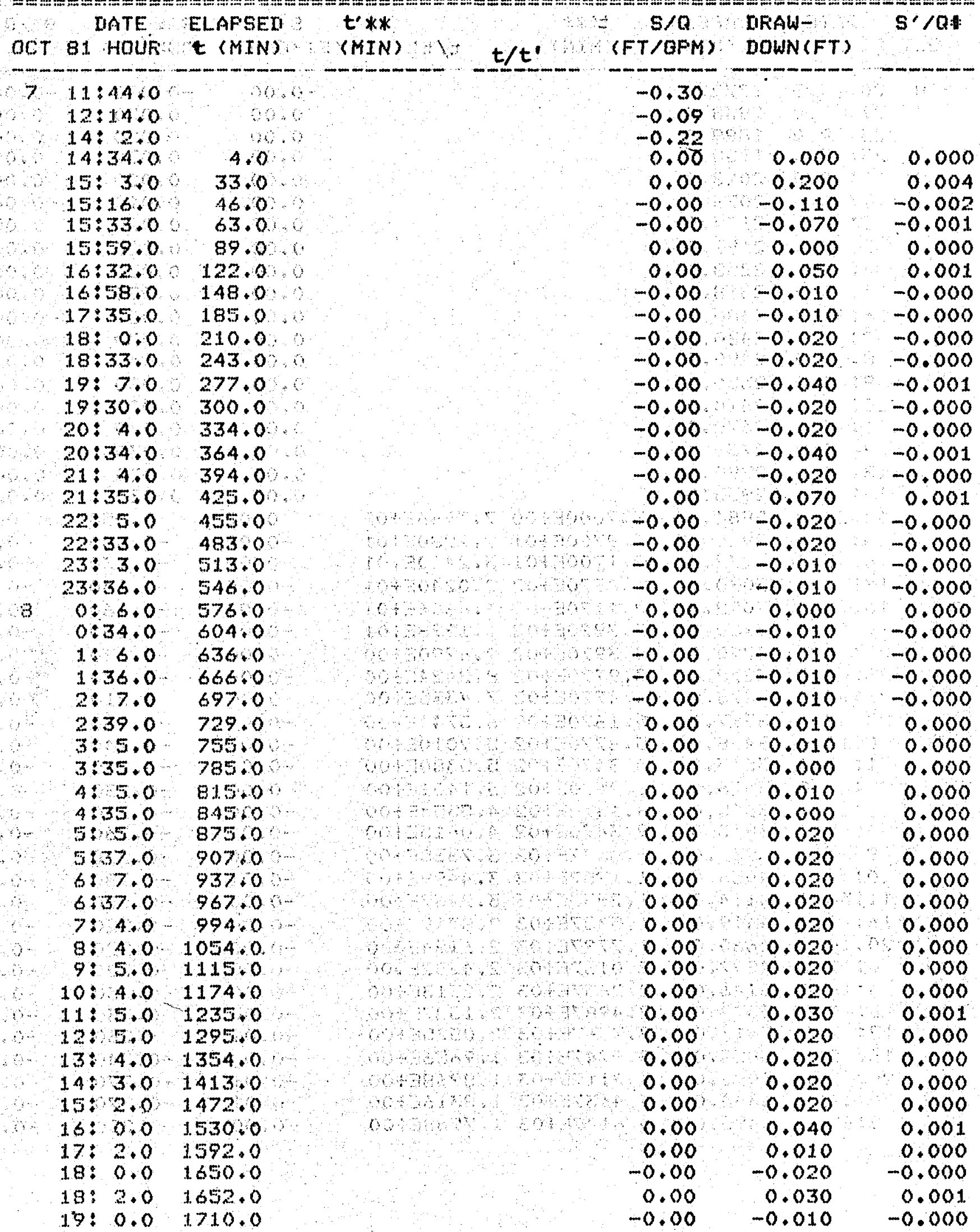


TABLE D-7. (continued)

North observation we 1 menrm tost -

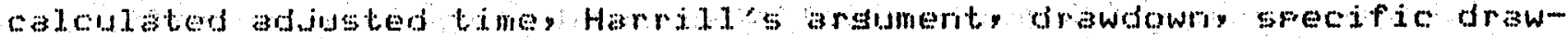
down (s.o) and sfocitic drawown adjusted for uacob's correctar (s'/a)

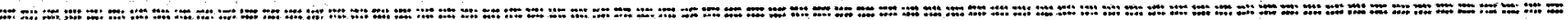

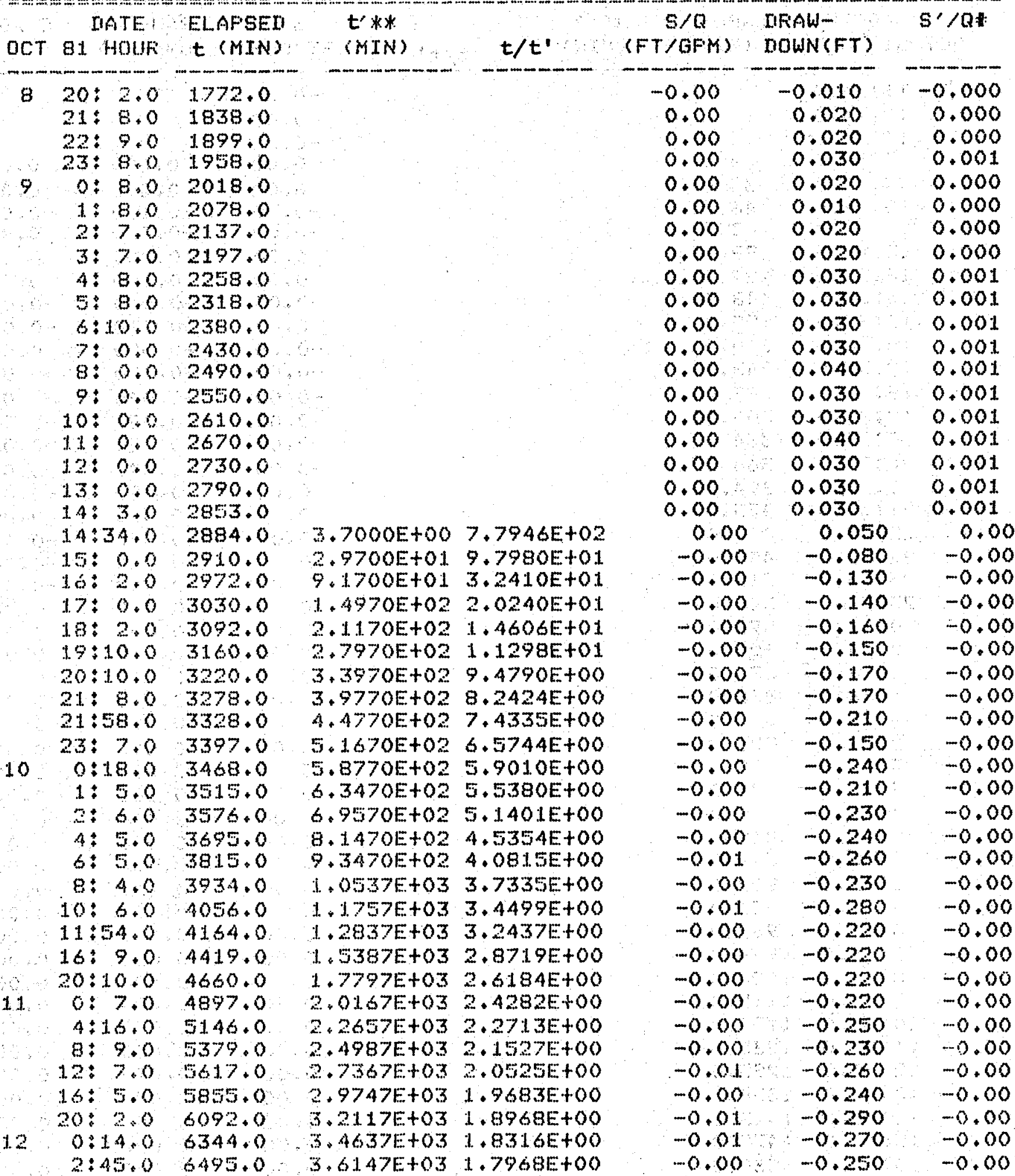




\section{6x,}

TABLE D-7. (continued)

\#S' IS THE JACOE CORRECTION $S^{\prime}=5-5 * 2 / 2 n$.

THE IIRAWLOWN $S$ AT ELAPSED TIME T IS CALCULATEI FROM THE EQUATION:

$$
S \text { - OBSERUED DEFTH TO WATER AT TIME T-TRENI }
$$

WHERE TFENI $=0$ * ELAFSED TIME + INITIAL IIEPTH-TO-WATER.

THE LENGTH OF THE CONTFIBUTING INTEFUAL OF THE WELL IS 34 FEET.

THE IIEFTH FFOM THE TOP OF CASING TO THE SCFEEN IS 4 FEET.

** $t^{\prime}$ IS THE TIME THAT HAS ELAFSEI SINCE THE FUMF WAS TURNED OFF.

$t$ IS THE ELAFSEI TIME FROM WHEN THE FUMF WAS TURNED ON.

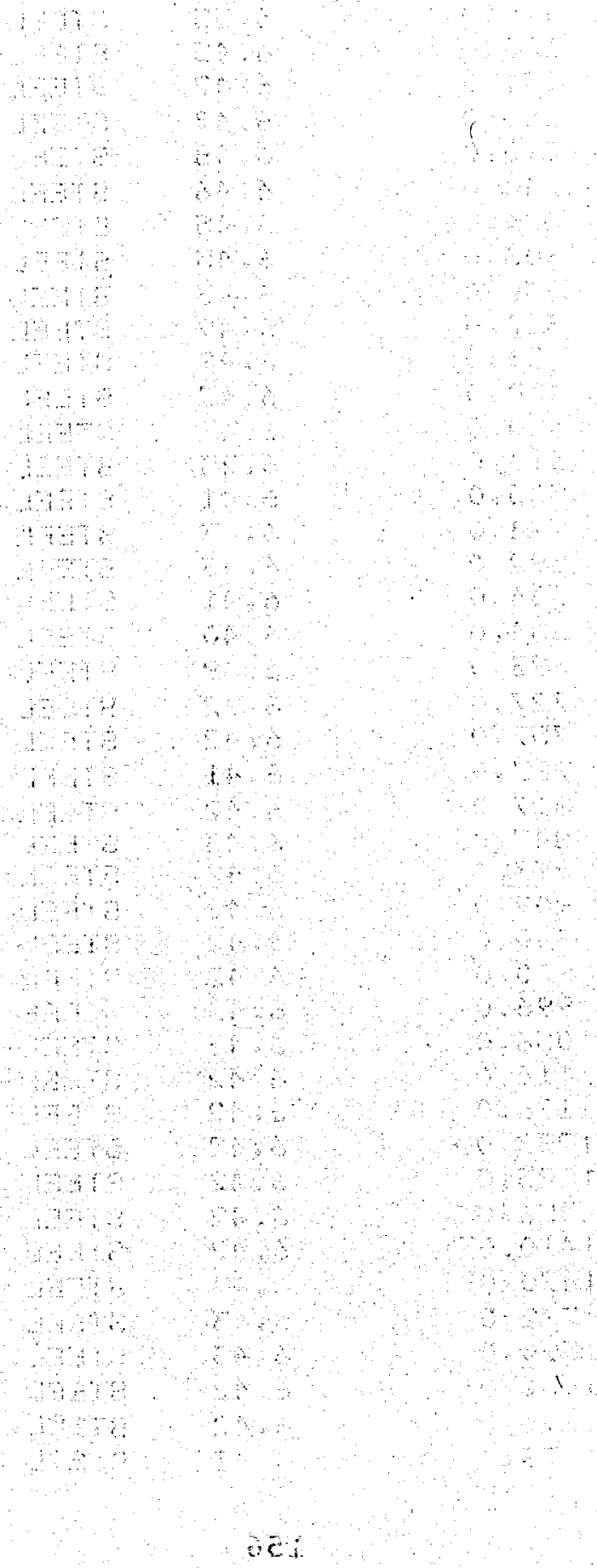

W. K. SUMMER 55 ANI ASSOCIATES, INC. 


\section{APPENDIX D}

TABLE D-8.

Gouth observation wel 1 pump test - water level data

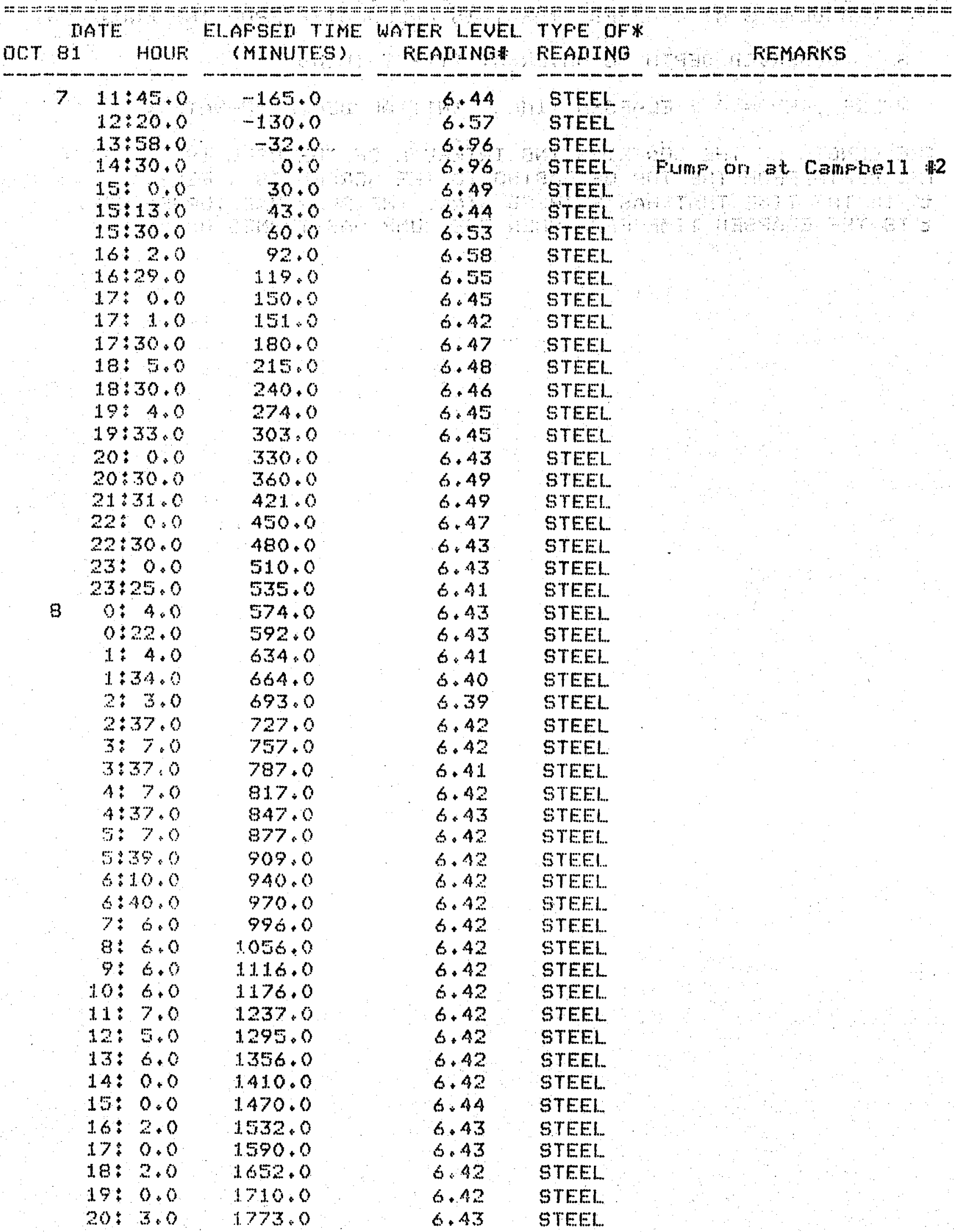




\section{TABLE D-8. (continued)}

South observation well punf test - water level data

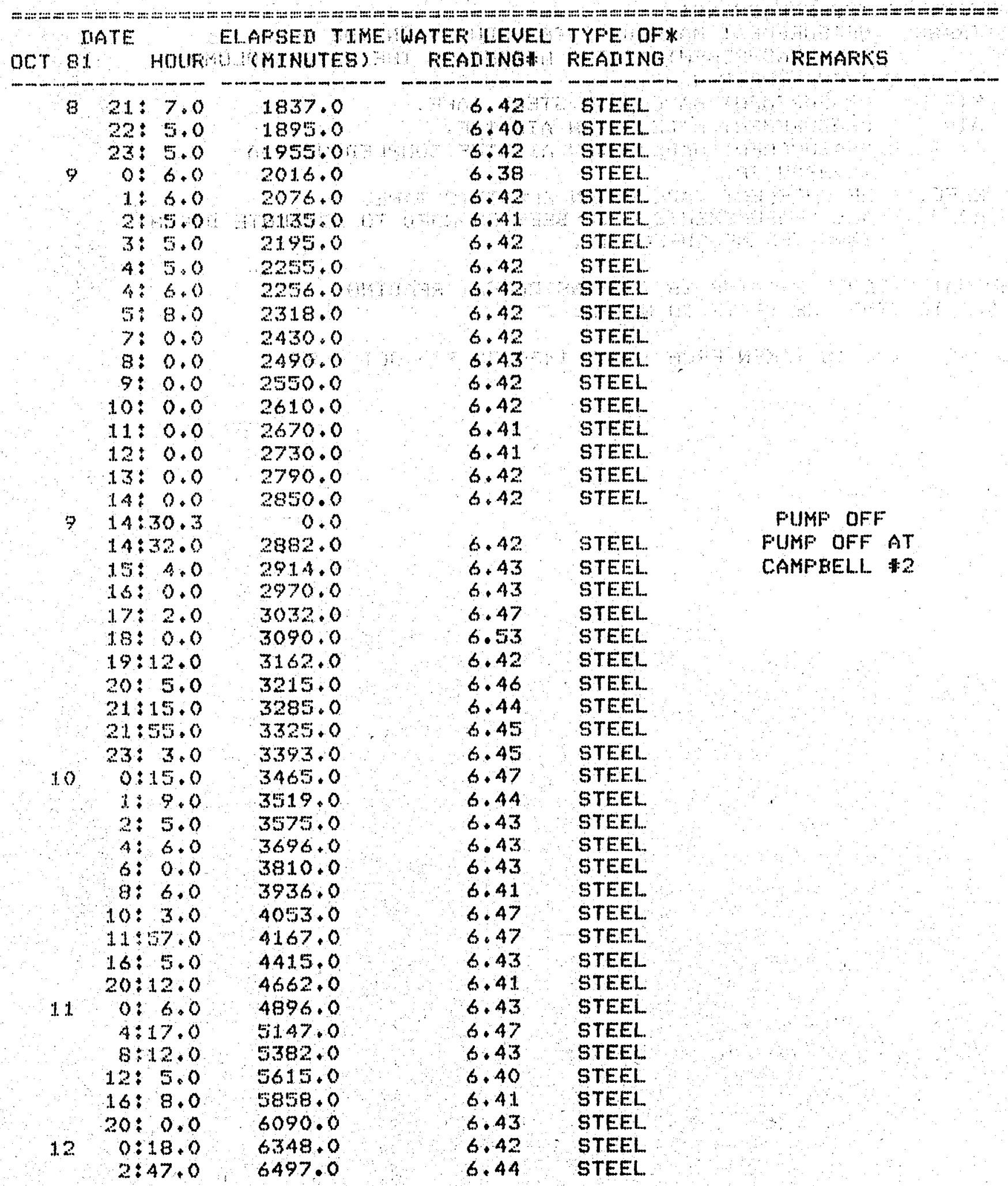

*THE TYFE OF REATINO IIENOTES THE TYFE OF 
TABLE D-8. (continued)

DEFTH TO WATEF MEASUREMENT MAIE. THESE MAY

BE ANY OF THE FOLLOWING:

TFANS - MEASUREMENT MAUE BY A TRANSDUCEF IN THE WELL. THE MEASUFEMENT IS THE HETGHT OF THE WATEF COLUMN

STEEL M MEASUFEMENT MAME BY A STEEL TAFE.

AIF $=$ MEASUFEMENT MAIIE RY AN ATRLINE.

ATFTRAN MEASUREMENT MAIE BY AN AIFLINE COUFLEN WTTH A TFANSRUCEF.

ELECT:= MEASUREMENT MADE BY AN ELECTRIC TAFE.

ABSOL $=$ ALL MEASUREMENTS HAUE EEEN CHANGEX TO ARSOLUTE IIEPTHTO-WATER MEASUFEMENTS.

\#THE WATEF LEVIEI. REATTNG TS THE TNSTFUMENT REATING

MARE TO FINT THE TEFTH TO WATER.

ELAFSED TIME TS TAKEN FROM TO AT 1430 ON 7 - OCT - 81 


\section{APPENDIX D}

TABLE D-9.

Gouth observtion well purf test - desth to watier

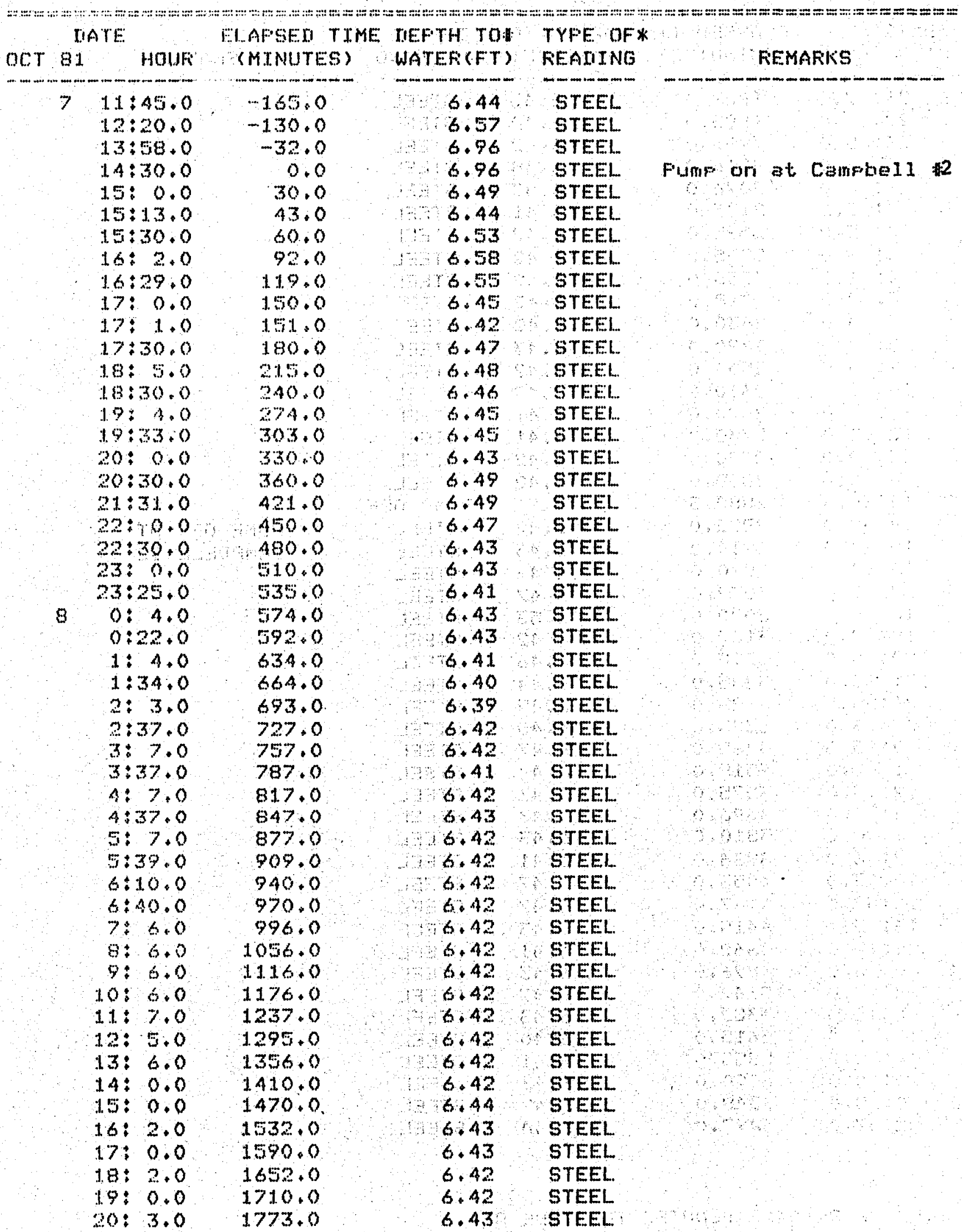

$159 \quad 0,1$ 
TABLE D-9. (continued)

South observetion wed primp test m- depth to water

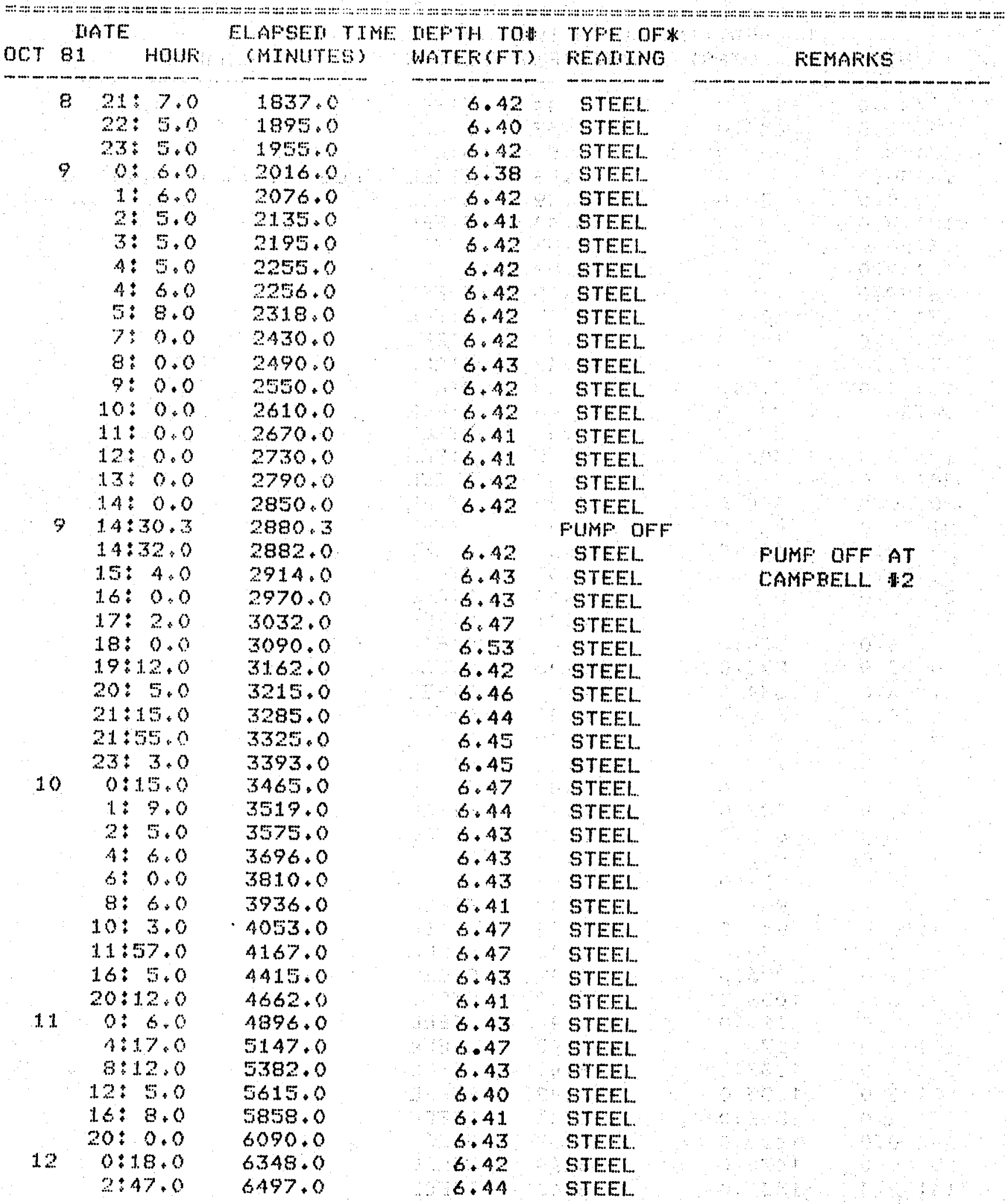

*THE TYFE OF FEATING IIENOTES THE TYFE OF 
TABLE D-9. (continued)

DEFTH TO WATEF MEASUFEMENT MAIE. THESE MAY

BE ANY OF THE FOLLOWING:

TFANS = MEASUFEMENT MAIE BY A TRANSIUUCEF IN THE WELL. THE MEASUREMENT IS THE HEIGHT OF THE WATER COLUMN ABOUE THE SENSOF.

STEEL := MEASUFEMENT MAIE BY A STEEL TAPE.

AIR =- MEASUFEMENT MALIE BY AN AIRLINE.

AIRTRAN=MEASUREMENT MADE EY AN AIFLINE COUFLEN WITH A

TRANSIIUCEF + T.

EIECT = MEASUREMENT MADE EY AN ELECTRIC TAPE.

AESOL - ALL MEASUFEMENTS HAVE BEEN CHANGED TO AESOLUTE IEEFTHQSTO-WATEF MEASUREMENTS.

ITHE TEFTH TO WATEF TS THE CALCULATEI IEFTH TO WATEF FFOM THE TOF OF THE WELL CASING, I FEET ABOVE THE LAND SUFFACE.

THE IEFTH TO WATEF BELOW THE TOF OF THE CASING IS COMFUTER BY THE FOFMULA,

FOR STEEL, NEFTH TO WATER = WATER LEVEL READING

THE AUERAGE DISCHARGE DURING FUMFAGE IS 52 GFM.

ELAFSED TIME. IS TAKEN FFOM TO AT 1430 ON 7 - DCT - 819

\section{$161 \quad \$$}

W. K, SUMMERS AND ASSOCTATES IINC. 
TABLE D-10. South Observation well pum test -

calculated adjusted time. Harrili's arsument, drawdowng soecific drawdown $(s / a)$ ard sfecific drawdown adjusted for Jacot's correction $\left(s^{\prime} / a\right)$ =

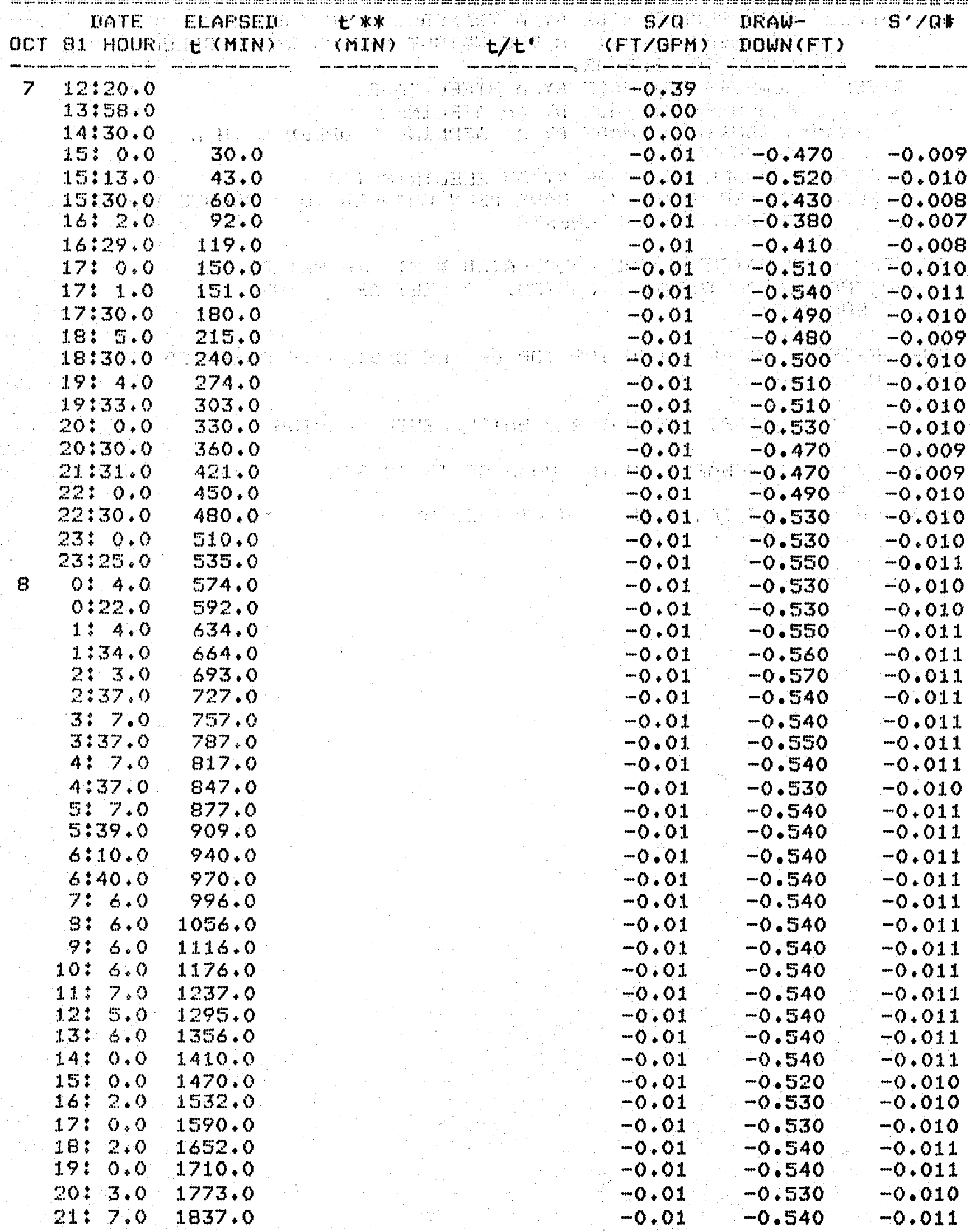


TABLE D-10. (continuegd)

calculated adjusted time, Harrili's arsument, brawdowris specific drawdown $(s / Q)$ arid specific drawown adjusted for Jacob's correction $\left(s^{\prime} / Q\right)$

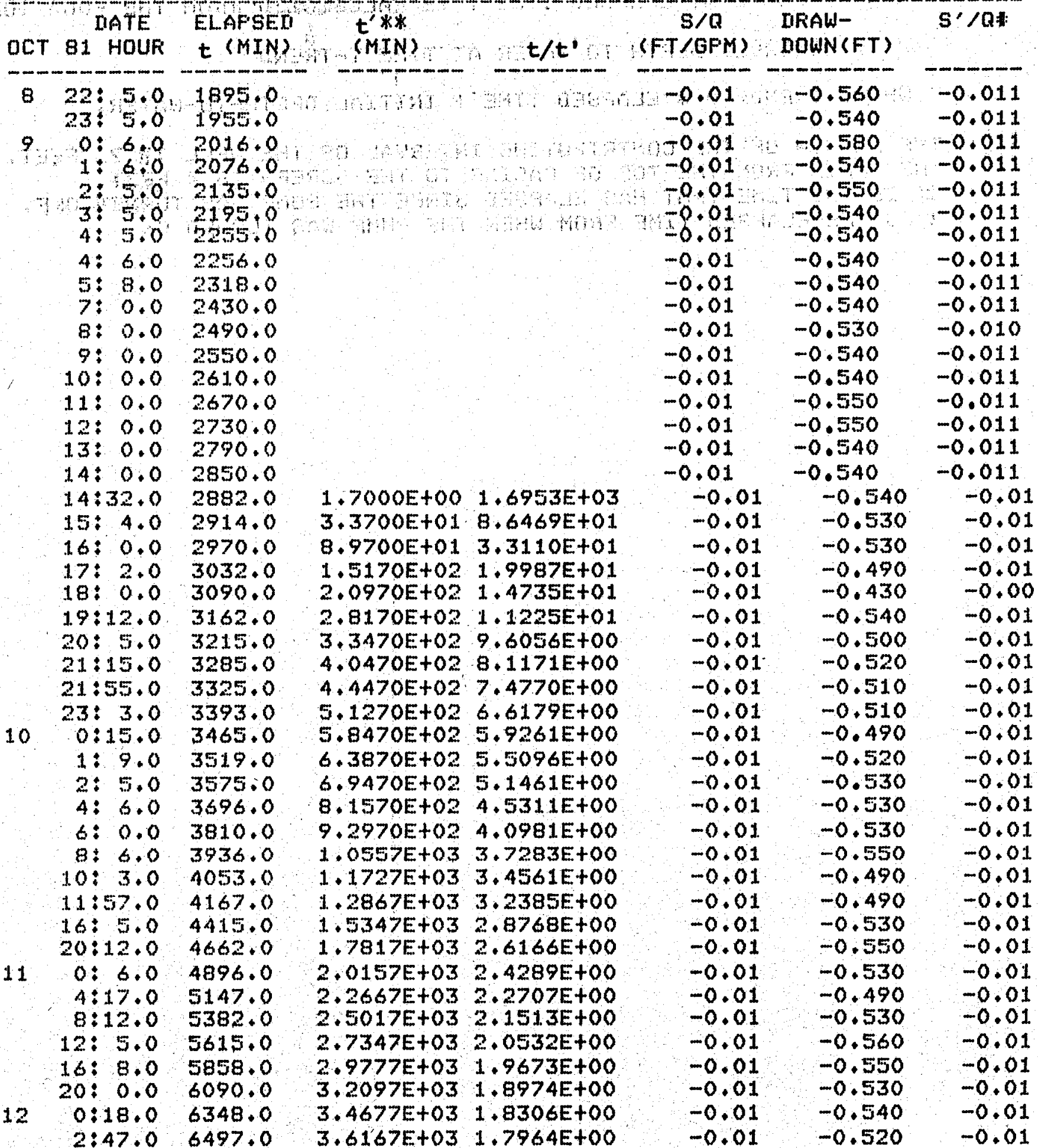




\section{TABLE D-10. (continued)}

\#S' IS THE JACOE CORFECTION, $S^{\prime}=5-5 * 2 / 2 \pi$.

THE IIFAWIOWN $S$ AT ELAFSEI TIME T IS CALCULATER FROM THE EQUATIDN:

$S$ - OESEFUEN IIEFTH TO WATER AT TIME T-TRENI

WHEFE TFEND= 0 * ELAFSEN TIME + INITIAL IIEFTH-TO-WATEF ?

THE LENGTH OF THE CONTRIBUTING INTERVAL OF THE WELL IS 71 FEET. THE IIEFTH FFIOM THE TOF OF CASING TO THE SCFEEN IS 4 FEET. ** $t$ ' IS THE TIME THAT HAS ELAFSEI SINCE THE FUMF WAS TURNEU OFF. $t$ IS THE ELAFSEI TIME FROM WHEN THE FUMF WAS TURNED ON. 
ar nar an an and

$\therefore$ 4.

\section{APPENDIX E}

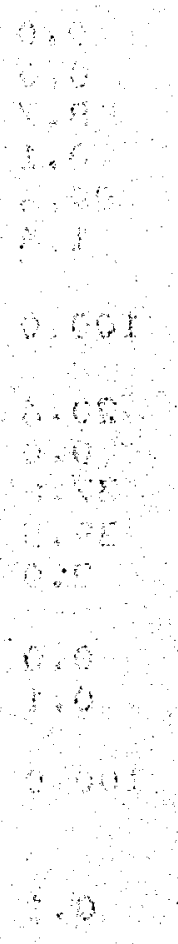

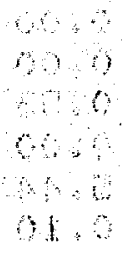

WATER CHEMISTRIES

\section{$a^{2}$}

9

$4+24 \pi \mathrm{a}$

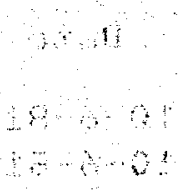

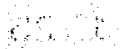

8

.

i.

sec

as

- montana
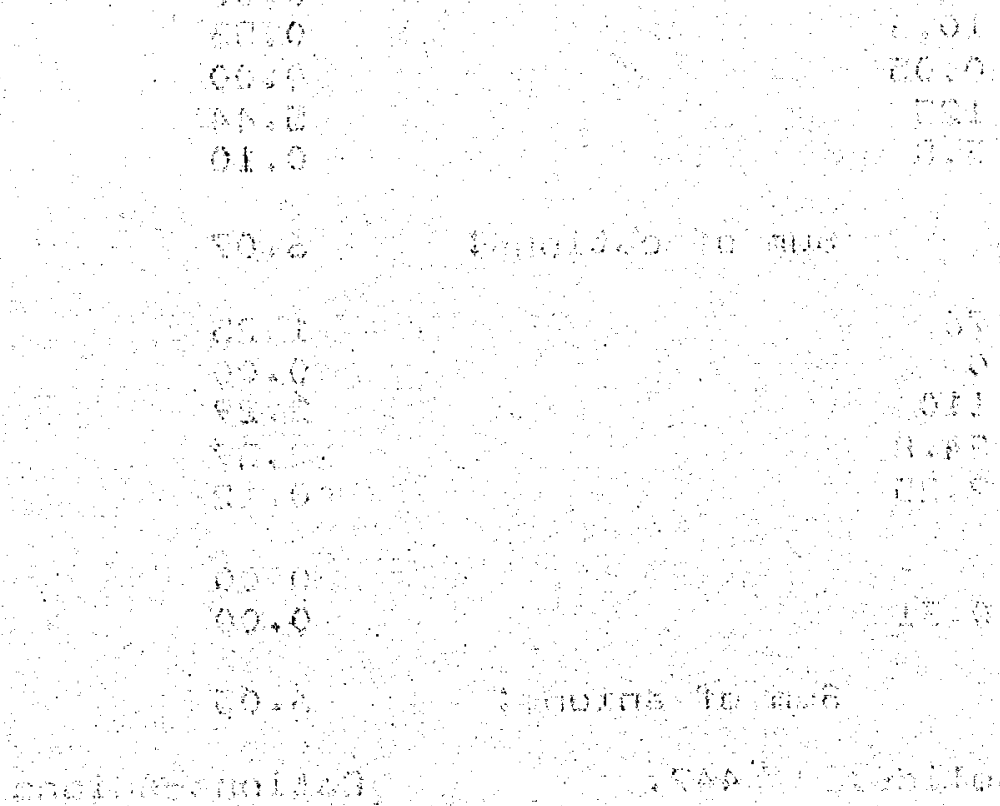

क्ष
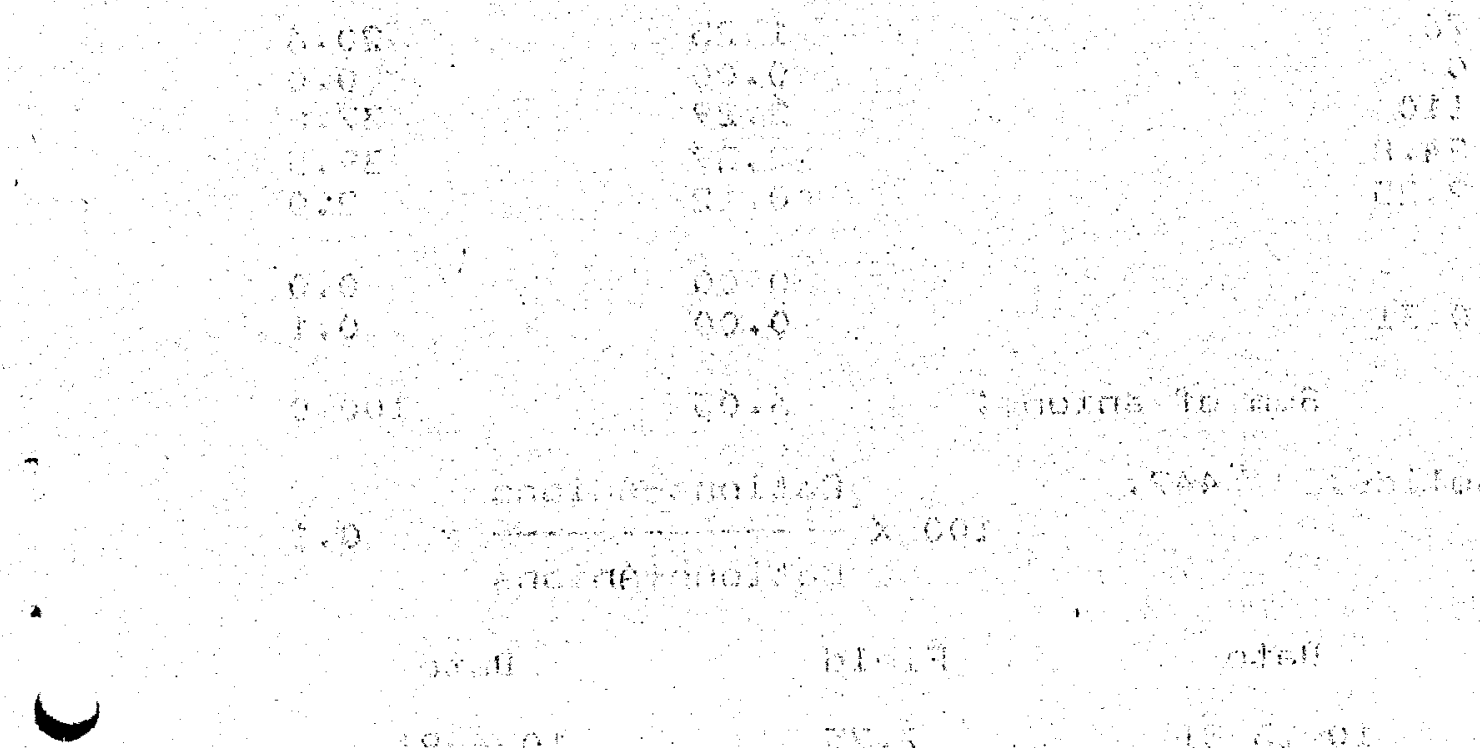

$165 \partial 0$ 


\section{APPENDIX E}

-HEETTCAL ANALYSTS OF WATEF

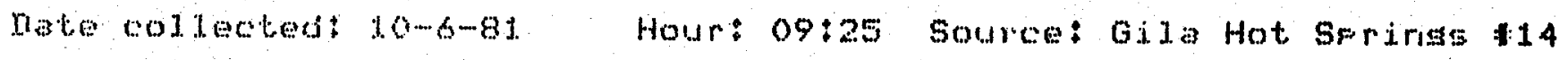

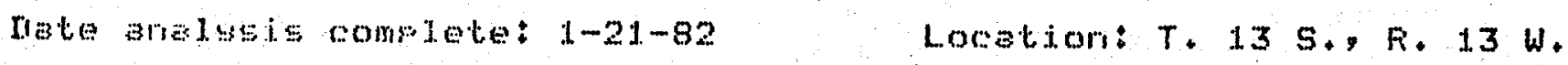

Laboratorst New Menteo Bureau of Mires Sec. 3.213

Laboratory No.: 1467

Source of data: NMEMMF:

Fil. No.: GHS14

Fienarks

Temperature when sampled $=66 \mathrm{C}$.

Other: old bathhouse sfrins

Copper $<10$ Fob zine 0.05 fomy selenium 0.02 pry

Lithium 0.25 prmo Nickel 0.1 prmy Chromium 2 peb

Uranium $0.05 \mathrm{prm}$

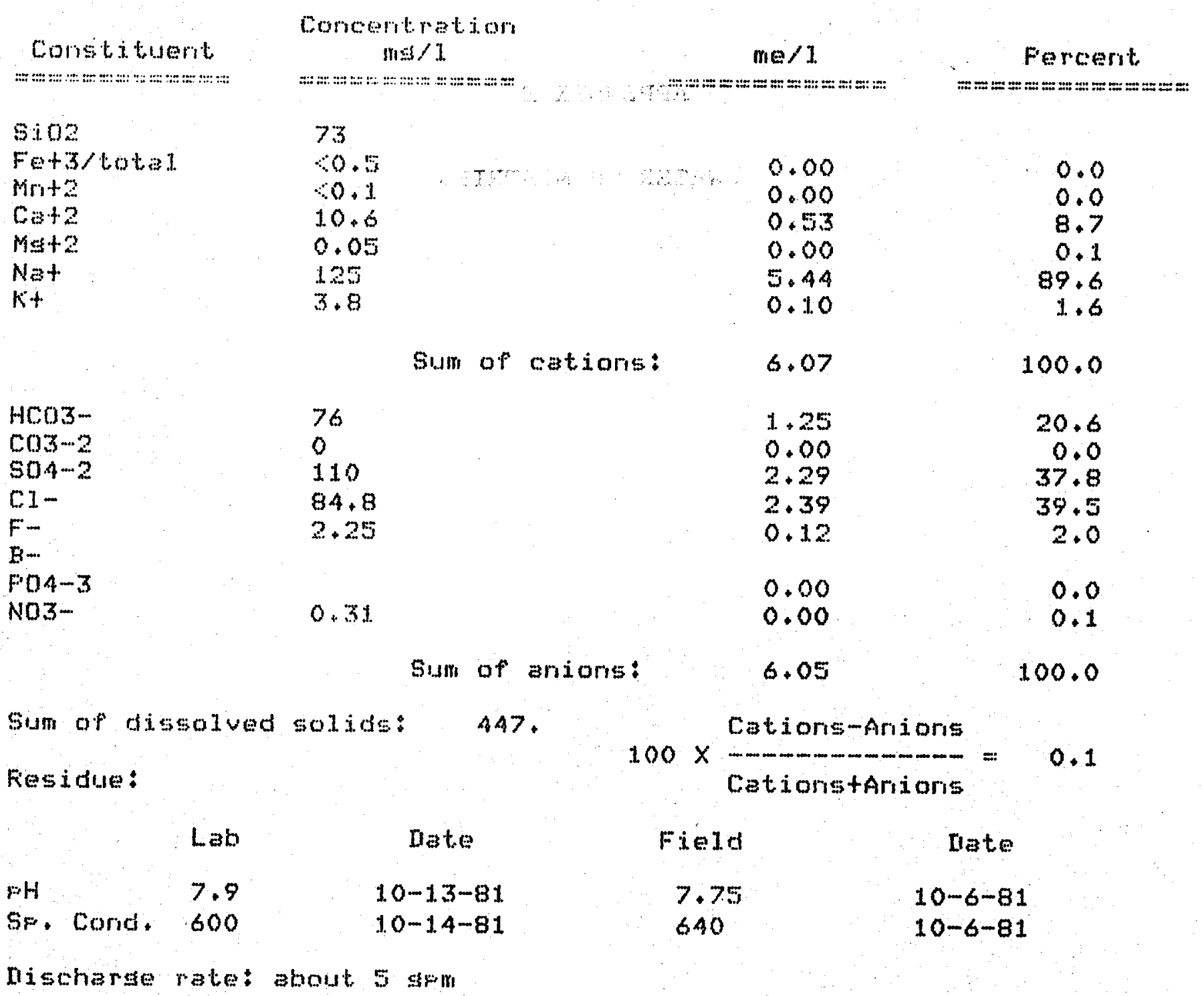




\section{APPENDIX E \\ CHEMIOAL ANALYSIS OF WATEF}

Date coldected 10-6-81 Hourt 09\$35 Source Gila Hot Sorings \$41

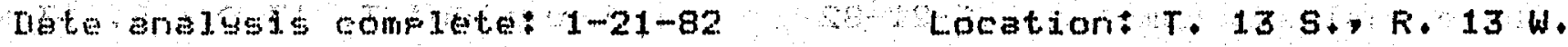

Laboratory

Laboratory No: : 1469

Sourco of data 1 NMEMMF

Fi1e No : GHS41

Fingertss

Dther: one of the pifed sprinss

Temperature when sampled $=58 \mathrm{C}$.

Copfer $<10$ pro, Zirie 0.05 fom Selenium 0.02 fom

Lithium 0.25 pmo Nicke $1<0.1$ grm, Chromium 2 sob

Uranium 0.05 rom

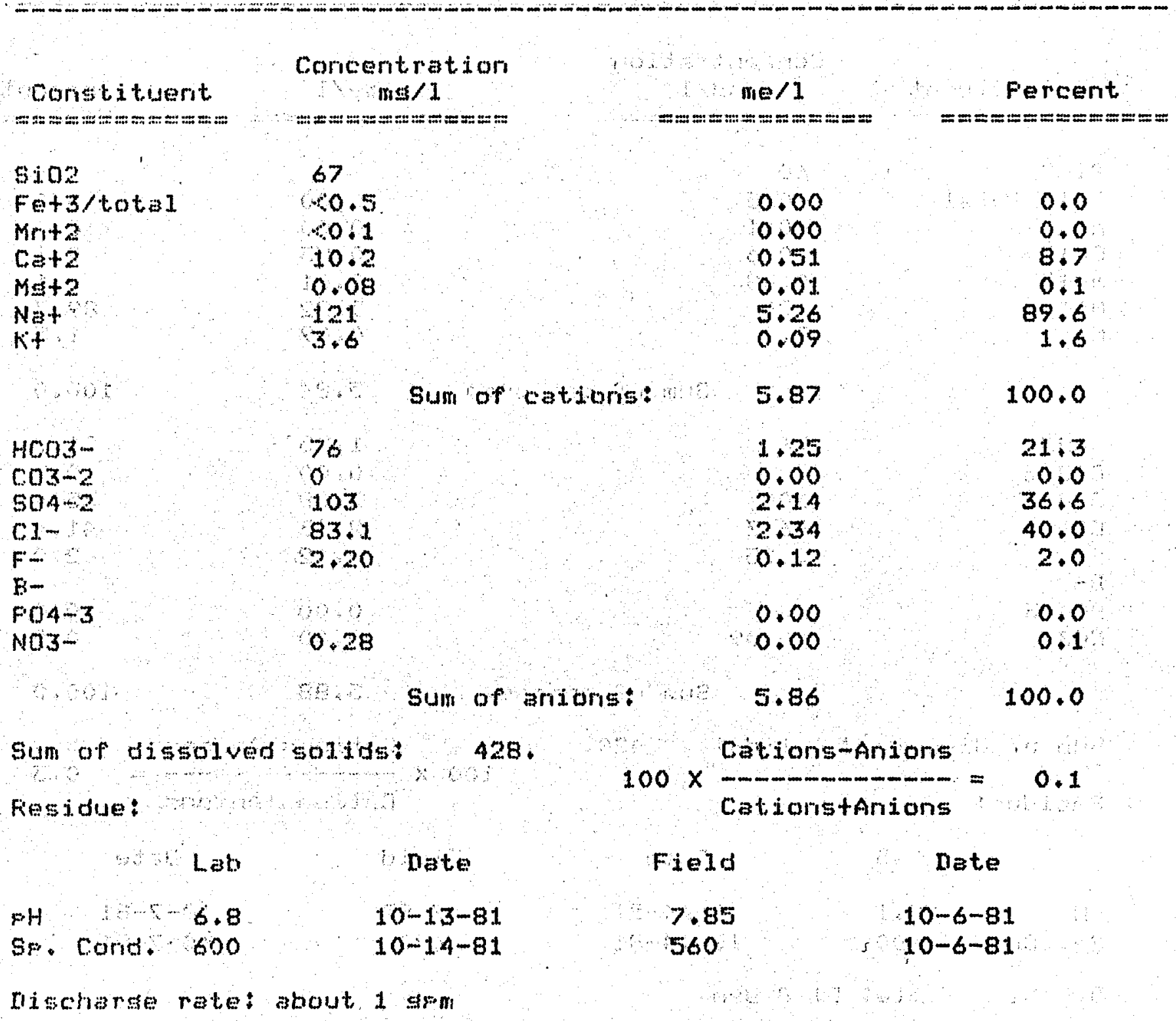




\section{APPENDIX E}

CHEMICAL ANALYSIS OF WATEF

nate collected 10-7-81 Hour 14:45 Source We11 Campel1 et al. 2

late aralusis complete: 1-21-82

Laboratory: New Mexico Bureau of Mines

Laboratory No: 1473

Source of data: NMEMMF

Femertats

Temperature when simpled $=61 \mathrm{C}$.

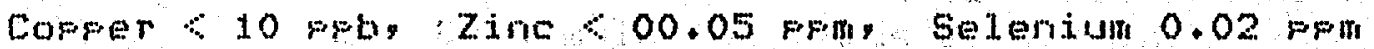

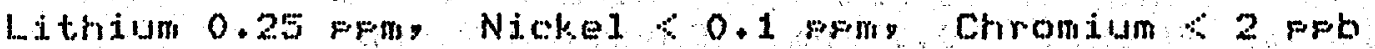

Uraritum $0.0 \%$ prin
FiJ NO: CMEL21

Dther: First sample in test. Sec. 5.212 


\section{APPENDIX E \\ WT CHEMICAL ANALYSTS OF WATEF}

Ietascollected: 10-7-81: Hour: 16:10 Sourcet We11 Camebe11 et al. 2 riate analesis complete 1-21-82 tocetiont T. 13 S., R. 13 W.

Laboratory: New Mexico Rureau of Mines et Se. 5.212

Laboratory No: 1471

Source of date: NMEMMF

FIJ NO.: CMEL22

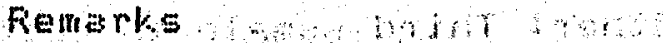

Dther: Second semple in test.

Temperature when sampled $=62 \mathrm{C}$.

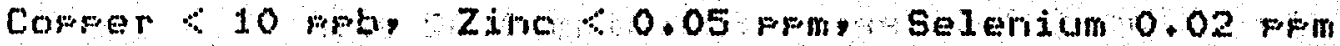

Lithium 0.25 frm, Nicke1 0.1 kgmb Chromium 2 pob

Uramium $<0.05$ prm

Comstituent

10:-

Sido2

$\mathrm{Fet} 3 / \mathrm{total}$

$M n+2$

$\mathrm{Ca}+2$

$\mathrm{Mat} 2$

$\mathrm{Nat}$

$k+$

98

HCO3-

$\mathrm{Co3}-2$

$504-2$

CI-

$F$

B-

$\mathrm{FOA}_{-3} \mathrm{3}$

$\mathrm{NOB-}$

\section{Concentration}

as $\mathrm{ms} / 1$

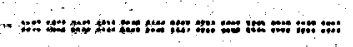

65

60.5

0.1

10.2

0.08

118

3,4

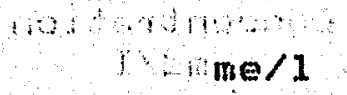

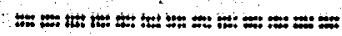

Fercent

=

0.0

0.0

8.9

0.1

89.5

1.5

$a$

Sum of cations: $\quad 5.74$

100.0

76

0

100

1.25

0.00

2.08

2.30

81.4

2.15

0.11

21.7

0.0

36.3

40.0

2.0

0.0

$\times 0.09$

0.00

0.00

0.0

on sum of ranows 5.74

100.0

Sum of dissolved solidst 418 .

$\therefore$ and

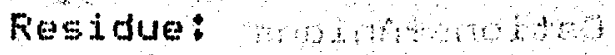

\& Lab

$\because H \quad 8.1$

SF. Comd. 600

Late

$10-1.4-81$

$10-14-81$

Cetions-Amions

100

CationstArioris

0.0

Figid

7.97

590
Inte

$10-7-81$

$10-7-81$

nischarge rate: 50.0 sfon 


\section{APPENDIX $\mathbf{E}$}

CHEMTCAL ANALYSIS OF WATER

Hate collected: 10-7-81 Hour: 22:52 Sourcet Wel1 Campbe11 et al. 2

Ilate analusis complete: 1-21-82 Locationt T+13 S., R. 13 W.

Laboratory: New Mexico Rureau of Mines Sec. 5.212

Laborators No: : 1468

Source of data: NMEMMF

File No.: CMEL23

Fimarks

Temperature when sampled $=60 \mathrm{C}$.

Other: Third samole in test.

Copper $10 \mathrm{prb}$. Ziric $<0.05$ perm selenium $0.02 \mathrm{pm}$

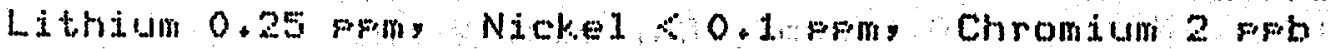

Uranium 0.05 From

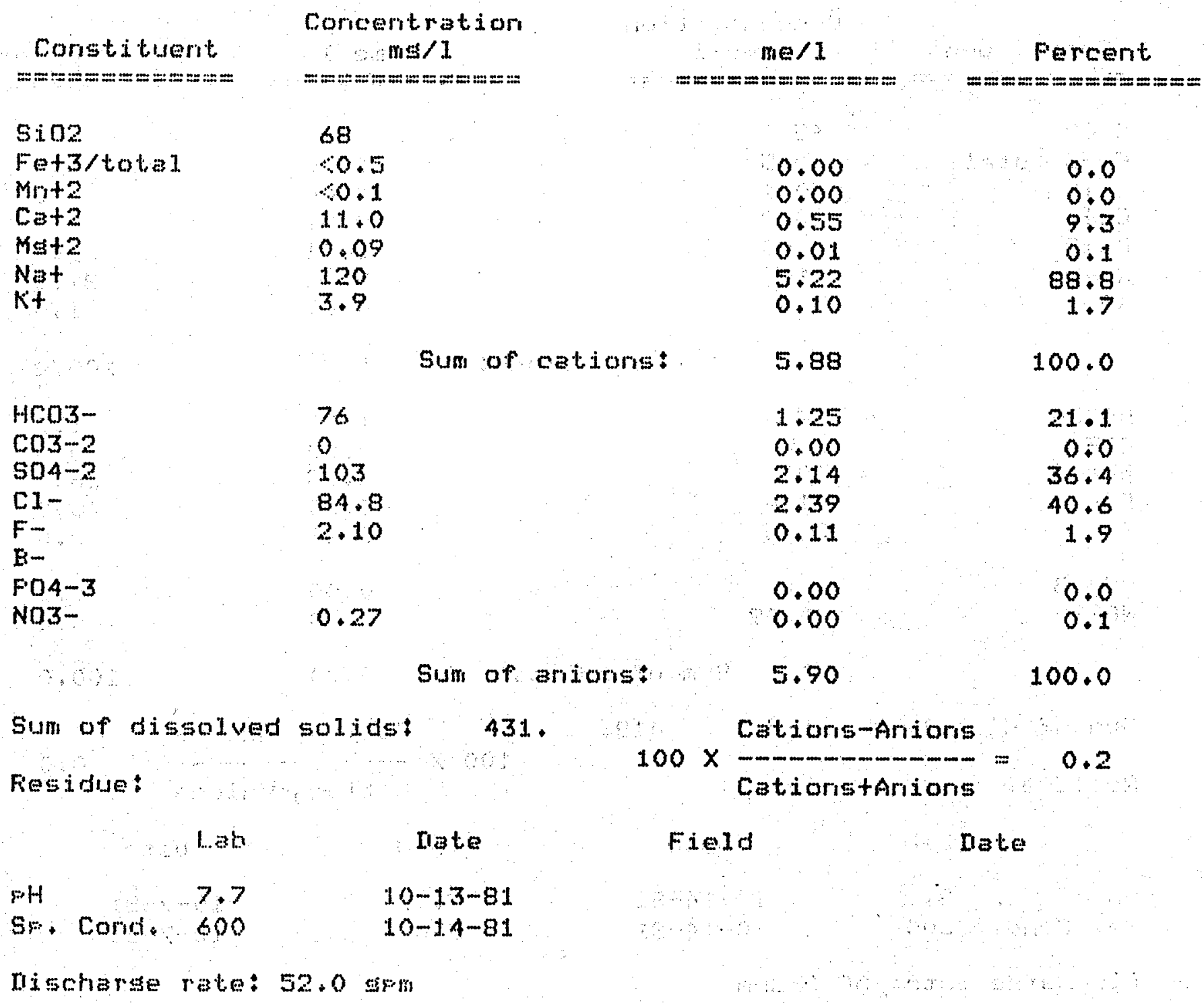




\section{APPENDIX $\mathrm{E}$}

\section{CHEMITAL ANALYSTS OF WATEF}

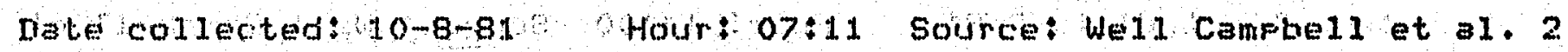

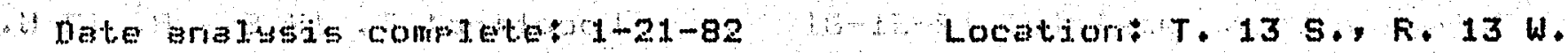

Laborators: New Mexico Eureas of Mines Sec. 5.212

Laboratory No.: 1470

Source of data NMEMMR

FiIO NO.: CMBL24

Remarks

Temperature when sampled = 6J. C.

Other: Fourth sample in test.

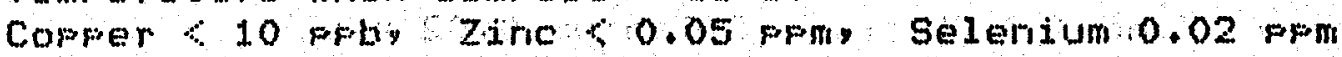

Lithium 0.25 prom Nicke1 0.1 pom, Chromium 2 rob

Urarium 00.05 Fom

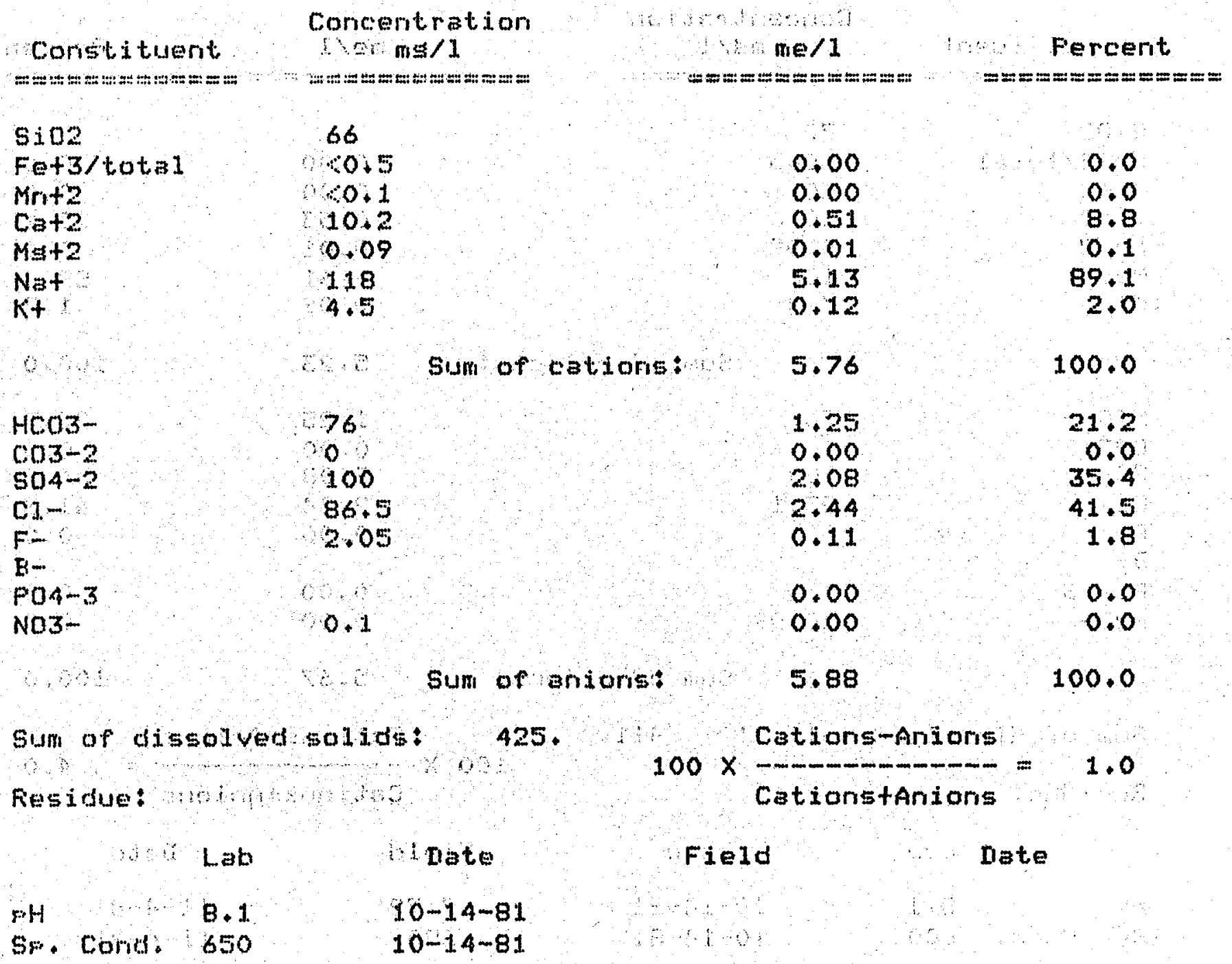

nischarse rate: 51.8 srom 


\section{APPENDIX E}

\section{CHEMICAL ANALYSIS OF WATEF}

Iate collected: 10-9-81 Hour: 14:00 Source: We11 Cambell et al. 2

nate aralusis complete: $12-31-81$

Location: T, 13 S., F. 13 W.

Laborators: New Mexico Bureau of Mines

$\sec \cdot 5 \cdot 212$

Laboratory $\mathrm{No}+1472$

Source of dati: NMEMMF:

FiI NO : CMBL25

Femarks

Temperature when sampled $=62 \mathrm{C}$.

Other: Fifth samole in test.

Copper $<10 \mathrm{pob}$, Zino $0.05 \mathrm{pFm}$, Selenium $0.02 \mathrm{FFm}$

Lithium 0.25 fom, Nicke1 $\$ 0.1$ frm, Chromium 2 fro

Uraridum 40.05 PFm

\section{Constituent}

:

Si02

Fotz/total

$M r+2$

$\mathrm{Ca}+2$

$\mathrm{Ms}+2$

$\mathrm{Nat}$

kit

\section{Concentration} $m \leq 11$

:

70

$<0.5$

$0+1$

10.6

0.09

106

$3+4$

Sum of cations:

76

0

100

83.1

20.09

$14003-$

CO3-2

504-2

Cl-

$F-$

E-

FO4-3

NO3-
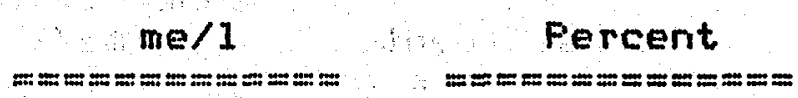

0.00

0.00

0.53

0.01

4.61

0.09

$5 \cdot 23$
1.25

0.00

2.08

2.34

0.00

0.00

0.00

5.67
100.0
0.0
0.0
10.1
0.1
88.1
$1 \cdot 7$

$22+0$

0.0

36.7

41.3

0.0

0.0

0.0

100.0

Sum of dissolved solids:

411.

Cations-Anions

Fiesidue:

Sum of anions:

4.0

CationstAnions

\section{Lab Nate}

$\mathrm{FH} \quad \mathrm{B} . \mathrm{L}$

SF. Corid. 600

$10-14-81$

$\mid 0-14-81$
Field

7.72

550
Irate

$11-4-81$

$11-4-81$

Iischarse rate: 50.0 spm 


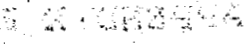

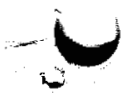

and

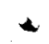

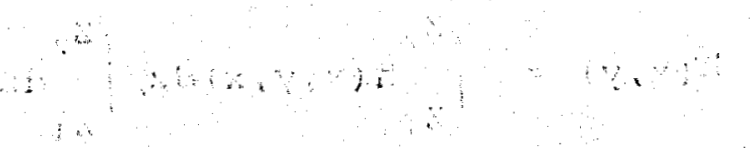

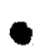

APPENDIX $F$

\section{VERTICALLY -AVERAGED HEAD}

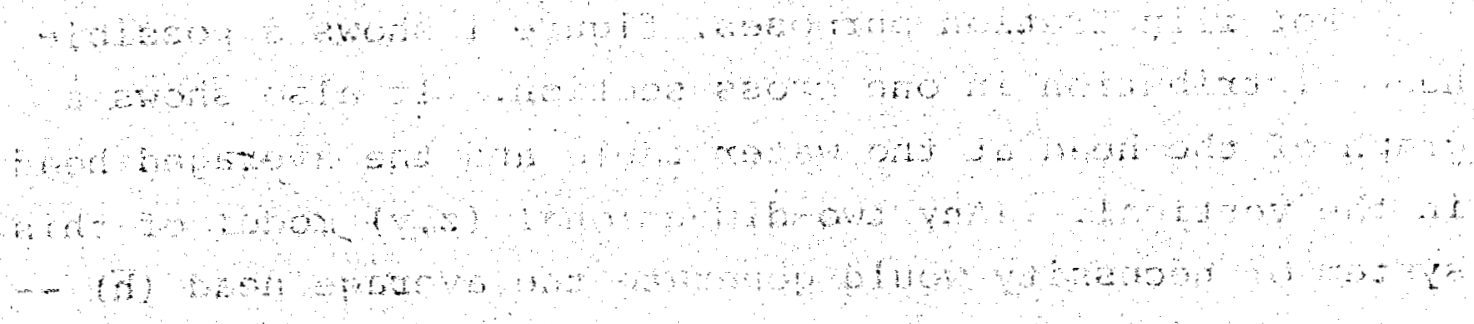

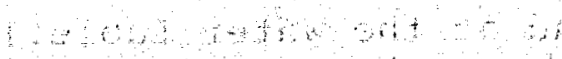




\section{APPENDIX F}

\section{VERTICALLY AVERAGED HEAD}

We define the vertically averaged head as follows:

$$
\begin{aligned}
\bar{h}(x, y) & =\int_{z_{1}}^{z_{2}} h(x, y, x) d z / \int_{z_{1}}^{z_{2}} d z \\
& =\frac{1}{\Delta z} \int_{z_{1}}^{z_{2}} h(x, y, z) d z
\end{aligned}
$$

where

$$
\begin{aligned}
& \Delta \mathrm{z}=\mathrm{z}_{2}-\mathrm{z}_{1}, \\
& \bar{h}(x, y) \text { is the vertically averaged head, } \\
& h(x, y, z) \text { is the three-dimensional head distribution, } \\
& z \text { is the variable in the vertical, and } \\
& z_{1}, z_{2} \text { are the limits over which we find the } \\
& \text { average value of } h(x, y, z) \text {. }
\end{aligned}
$$

Most ground-water systems, because they are threedimensional, exhibit substantial head variation along verticais $(z)$. The most variation occurs in recharge and discharge areas.

For illustration purposes, figure 1 shows a possible head distribution in one cross section. It also shows a graph of the head at the water table and the averaged head in the vertical. [Any two-dimensional $(z, y)$ model of this system of necessity would generate the average head $(\bar{h})$ not the head at the water table.] 


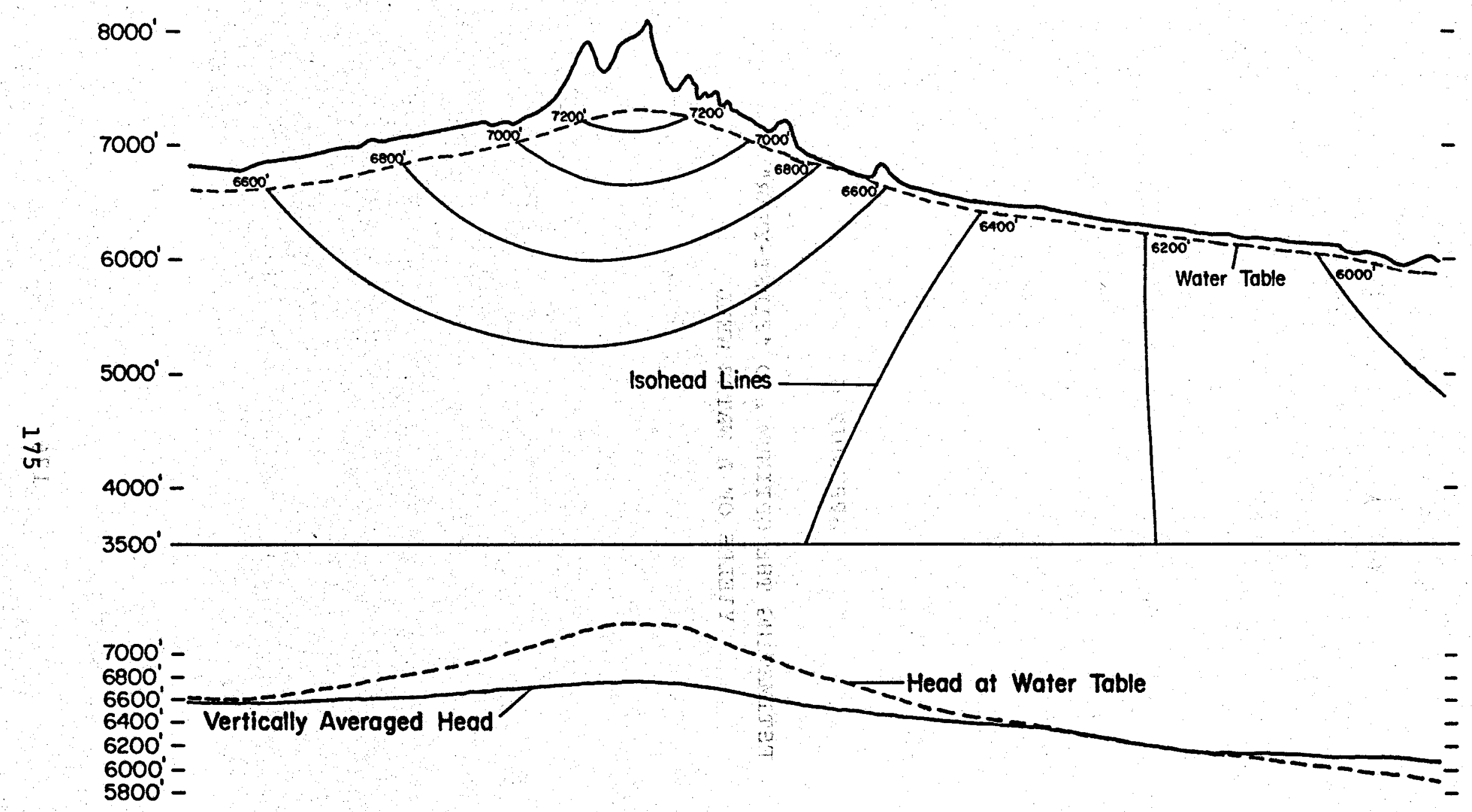

Figure F-1. Head distribution, head at the water table, and vertically-averaged head in one cross-section. 


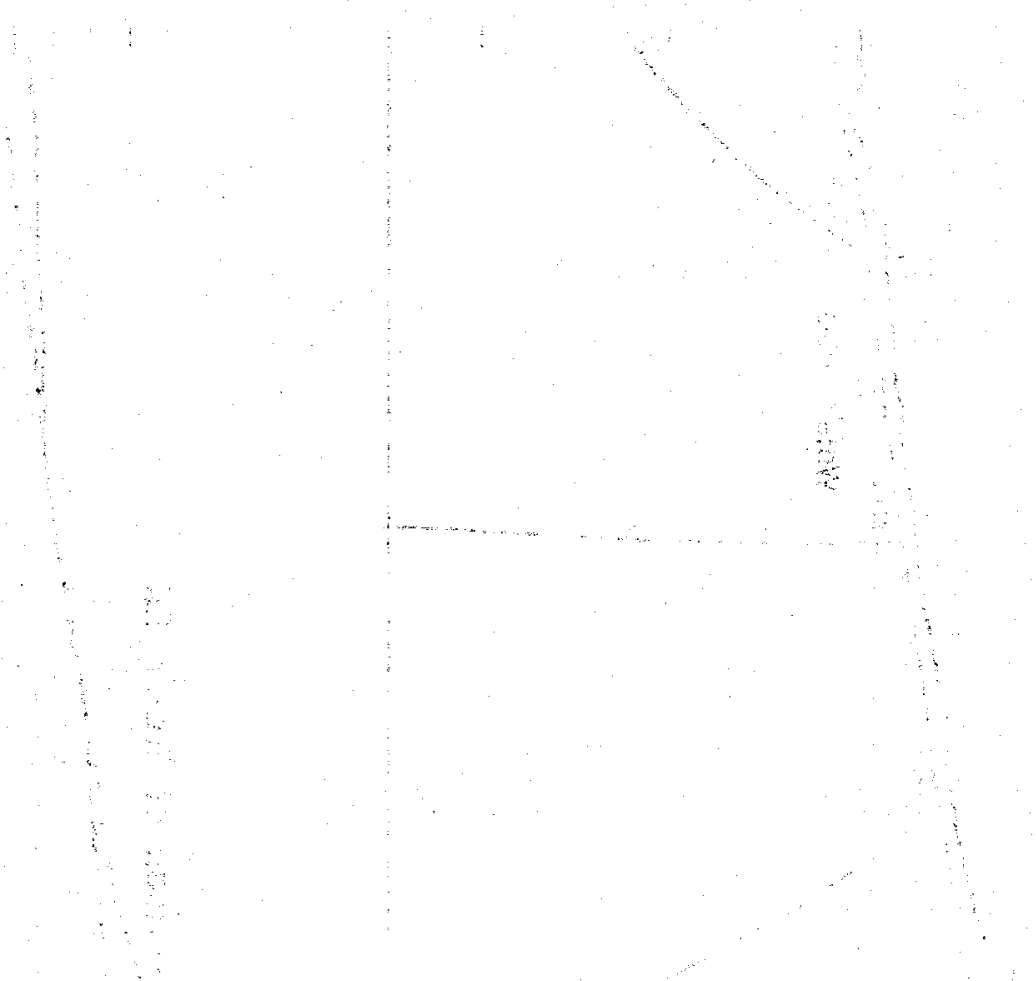

APPENDIX G

ESTIMATING THE OPTIMUM AND "FIRST-YEAR" YIELDS OF A WATER WELL 


\author{
APPENDIX $\mathbf{G}$ \\ ESTIMATING THE OPTIMUM AND "FIRST-YEAR" \\ YIELDS OF A WATER WELL \\ BY W.K. Summers
}

\title{
DEF INITIONS
}

The optimum instantaneous yield of a water well is the discharge that occurs when the water enters the well at the maximum permissible velocity. The "first-year" yield of a well is the volume of water the well will produce if it were to pump continuously for 365 days. We use "screen" for the interval through which water enters the we1l; the interval may actually be open hole, perforated casing, casing with torch-cut slots, wire-wrapped screen, or any other structure. "Screen" lets us avoid repeated use of phrases such as "contributing interval of the well."

\section{PURPOSE AND SCOPE}

This paper (1) presents equations for (a) estimating the optimum instantaneous $y$ ield (and the associated drawdown) at any point in time after pumping begins, taking well losses into account, and (b) estimating the "first-year" yield, and (2) discusses briefly the concept of maximum permissible entrance velocity. 
NOTATION

We use the following notation in our analysis:

a is the area of openings per foot of screen through which water enters the well ( $f t^{2} / f t$ ),

d is the length of the screen ( $f t$ ),

$\mathrm{H}_{0}$ is the initial (pre pumping) depth to the bottom of the screen from the water level in the well (ft),

Q is the optimum discharge rate (gpm),

$Q^{\prime}$ is the optimum discharge rate ( $\mathrm{ft}^{3} / \mathrm{sec}$ ),

$\bar{Q}$ is the arithnetic mean discharge during a pumping period (gpm),

$r_{w}$ is the well raduis ( $f t$ ).

s is the drawdown (ft).

$\mathrm{S}$ is the coefficient of storage,

$t$ is the time (days),

$T$ is the transmissivity (gpd/ft),

$v$ is the velocity through the screen openings (ft/sec), and

$v$ is the volume of water pumped during a given time interval (gallons). 
In our analysis we assume that Theissian conditions apply. lof these, the most important is that $\mathrm{T}$ remains approximately constant during the pumping period.)

If the pumping water level is above the top of the screen of a pumping well ( $\left.\mathrm{H}_{0}-\mathrm{s} \geq \mathrm{d}\right)$

$$
v=Q^{\prime} / a d t / \sec
$$

or

expressing $Q^{\prime}$ in gpm gives

$$
Q=448.8 \mathrm{vad}
$$

In many cases the pumping level at the optimun pumping rate will be below the top of the screen. The screen length of the well then becomes $\mathrm{H}_{0}-\mathrm{s}$ rather than $\mathrm{d}$. So we have the maximum discharge

$$
Q=448.8 \mathrm{Va}\left(\mathrm{H}_{0}-\mathrm{s}\right)
$$

However, we also know that for many wells

$$
s=B Q+C Q^{2}
$$

where

$$
B=\frac{114.6}{T} \int_{u}^{\infty} e^{-u} / u d u_{v}
$$

where

$$
u=\frac{1.87 r_{w}^{2} s}{T t}
$$

or

if $u \leq 0.01$

$$
B=\frac{264}{T} \log _{1}\left(\frac{0.3 T t}{r_{w}^{2} s}\right)
$$


If we know $v, a, d, T, t, r_{w}, s$, and $c$ for the case where the pumping level is above the screen we solve equation (2) and then estimate $s$ using equation (4). However, for the case where the pumping level is in the screen, equations (3) and (4) become two equations with two unknowns. Substituting (4) in (3) and rearranging terms we get

$$
448.8 \mathrm{vaCQ}^{2}+(448.8 \mathrm{vaB}+1) \mathrm{Q}-448.8 \mathrm{vaH}_{0}=0
$$

so

$$
Q=\frac{-(448.8 \mathrm{vaB}+1)+\sqrt{(448.8 \mathrm{vaB}+1)^{2}-4(448.8 \mathrm{vaC})(-448.8 \mathrm{vaH} \sigma)}}{2(448.8 \mathrm{vaC})}
$$

In this case we solve equation (8) for $Q$, we then estimate s using equation (4).

These procedures give an estimate of the instantaneous optimum $Q$ and resulting $s$ at time $t$. The total discharge (V) for the time period $t_{1}$ to $t_{2}$ is then

$$
v=\left(s_{t_{1}}^{t_{2}} Q d t\right) \times 1440
$$

We obtain the first-year yield by setting $t_{1}=1$ and $t_{2}=365$ days. The average discharge rate is:

$$
\bar{Q}=V /\left(t_{1}-t_{2}\right) .1440
$$

\section{ENTRANCE VELOCITIES}

presumably the velocity at the exterior screen face is the fastest that the water achieves in moving through the rocks to the well. The ideal approach velocity is the one that is preceptibly less than is necessary to produce turbulent flow in the rocks near the well. That is, the Reynolds Number $\left(N_{R}\right)$ for the water-rock system near the well should be less than 100 . 
For ground water, $\mathrm{N}_{R}=10^{\prime} \mathrm{DV}$, where $\mathrm{D}$ is the conduit diameter in feet, and $v$ is the velocity in feet per second. Because, at $N_{R}=100, v=10^{-3} / D$, the diameter of the conduit controls the estimate of the optimum entrance velocity. Faster velocities are permissible in small-diameter conduits than in large-diameter conduits. So for flow through fine-grained rocks with intergranular pore diameters of $0.1 \mathrm{~mm}(.0003 \mathrm{ft})$, the maximum permissible velocity would be about $3 \mathrm{ft} / \mathrm{sec}$ : whereas for flow through coarse-grained rocks with intergranular pore diameters of $5 \mathrm{~mm}$ $(.02 \mathrm{ft})$ the maximum permissible velocity would be about .05 ft/sec. Fractures and solution features may give rise to larger conduit diameters and even slower maximum permissible velocities.

The maximum entrance velocity depends upon well-site conditions. Drilling the well can cause changes in the porosity characteristics of the rocks near the well bore and the bore may cross water-yielding rocks of diverse porosity characteristics. so in practice we may not be able--on the strength of the data in hand-to determine the maximum permissible velocity at the screen.

Johnson, Inc. $(1975, \mathrm{p} .193)$ suggest that the maximum screenentrance velocity should be less than or equal to $0.1 \mathrm{ft} / \mathrm{sec}$, because experimental evidence indicates that for wire-wrapped screens, this minimizes:

(a) friction losses,

(b) the rate of incrustation, and

(c) the rate of corrosion.

our experience in determining the optimum yields of wells of all sorts using $0.1 \mathrm{ft} / \mathrm{sec}$ as the optimum entrance velocity in- 
dicates that the $0.1 \mathrm{ft} / \mathrm{sec}$ is an acceptible value to use in day to day practice.

\section{DISCUSSION}

\section{Application}

The procedure outlined above requires the results of a step pumping test on the well for which the optimum and "first-year" yield is to be estimated. These tests generally provide $T$ and $C$. With an observation well during the step test $s$ may also be measured, but if no data on $S$ are available, a reasonable estimate of $\mathbf{S}$ can be made by either

(1) assuming that $s=d \times s_{s}=d \times 10^{-6} / f t$ (where $\mathrm{S}_{\mathrm{s}}$ is the specific storage), or

(2) assuming that $S=s_{y}=.05$ for rocks with intergranular porosity or $s_{y}=.005$ for rocks with fracture porosity (when $s_{y}=$ specific yield).

These assumptions are reasonable, because order-of-magnitude errors in the estimates of $s$ produce less than 20 percent error in estimates of $Q$ and $s$.

We can estimate a in three ways:

(1) from the construction records (the specifications for some louvered casing, mil1-slotted casing, and wire-wrapped or plastic screens give a),

(2) from television surveys of the well, or

(3) from the pumping-test data. 
To use pumping-test data to determine a, solve equation (8) by trial and error. Use as constants for the equation the values determined from the test and the last $t$ of the pumping period. Then, assume a value for a and solve for $Q$; if the computed $Q$ doesn't agree with the observed $Q$, change a appropriately and solve for $Q$ again. Repeat until the chosen value of a produces a computed $Q$ approximately equal to the observed $Q$. Then check the validity of all computed parameters by solving equation (4) for $s$; if the $s$ computed for the test approximately equals the observed s, predictions of the instantaneous optimum yield after one year of pumping and of the "first-year" yield can be accepted with confidence.

\section{Reservations}

The procedure for estimating optimum yields and "first-year" yield presume Theissian conditions. Thus, the impacts of nearby pumping wells and hydrologic boundaries are excluded from the predictions. To refine the predictions taking these factors into account may require geologic or hydrologic mapping, an inventory of nearby wells, or site-specific additional information. Moreover, because the major Theissian assumption is that all water came from storage, long-term estimates of $V$ may be too small because they fail to adequately take recharge into account.

\section{REFERENCE}

Johnson, Inc. (1975) Ground Water and Wells: St. Paul, Minnesota, $440 \mathrm{p}$. 


\section{Determination of Aquifer Parameters from Step Tests and Intermittent Pumping Data}

by Yüksel K. Birsoy and W. K. Summers

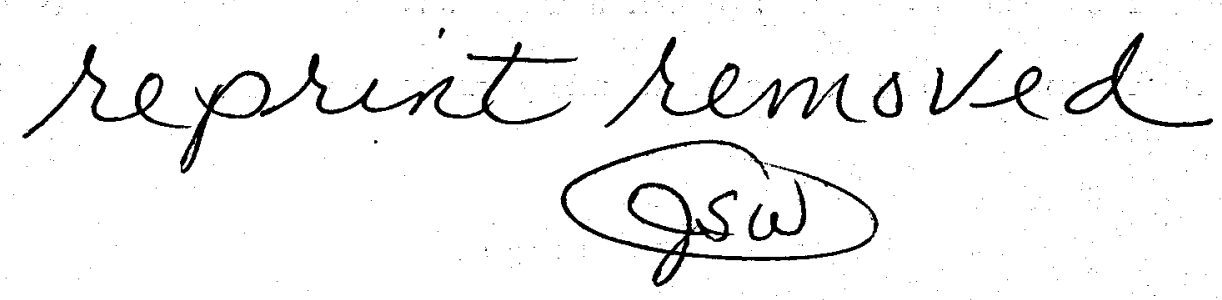

Reprinted from the March-April 1980, Volume 18, Number 2 issue of Ground Water 